\title{
Deterrence and Counterproliferation in an Age of Weapons of Mass Destruction
}

\author{
Derek Delbert Smith \\ Somerville College, Oxford \\ March 2004
}

Submitted in partial fulfillment of the requirements for the degree of

D.Phil. in International Relations in the Department of Politics and International Relations at the University of Oxford

Word Length: 65,000

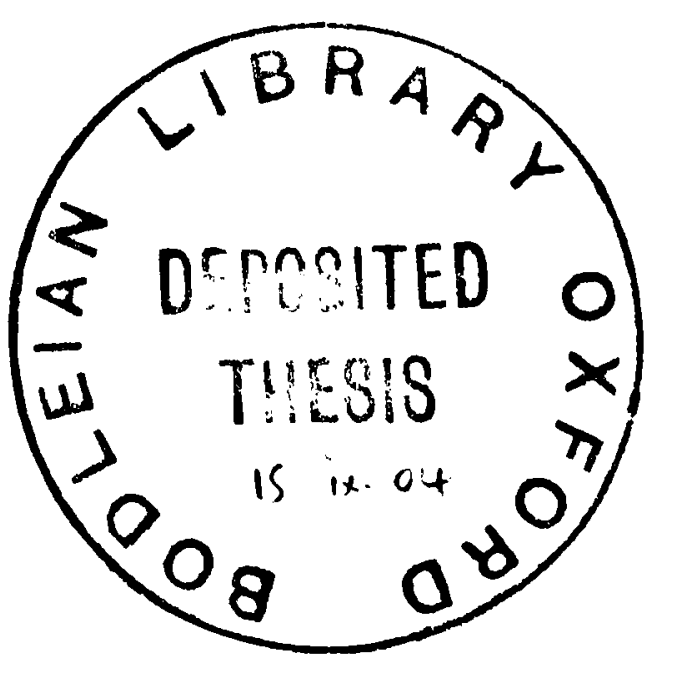




\section{Deterrence and Counterproliferation in an Age of Weapons of Mass Destruction}

Derek Delbert Smith, March 2004

D.Phil., International Relations, Somerville College, Oxford

Faced with America's conventional military superiority, many countries are turning to weapons of mass destruction as a means to deter U.S. intervention in their affairs. At the same time, 11 September 2001 awakened the United States to a degree of vulnerability it had never experienced before, making it increasingly unwilling to tolerate such weapons in the hands of unstable and unpredictable regimes, particularly those with connections to terrorist organizations. These twin fears of American encroachment and American vulnerability create a modern security dilemma, forming a vicious cycle of insecurity that challenges traditional notions of deterrence. It is unquestionable that the United States possesses the strategic capabilities to retaliate with devastating effect to any attack, but regional asymmetries of interest may tip the scales of brinksmanship in favor of potential adversaries, thereby dissuading American involvement in responding to global security threats. While this might be a welcome change to some, the United States is developing counterproliferation options to prevent, protect against, or destroy threatening weapons-reserving the right to use preemptive force-in order to retain freedom of action abroad and protect the homeland. This is a worthwhile objective, but deterrence will never be guaranteed by American strength, and unprovoked wars of disarmament will inevitably spark yet further proliferation and hatred toward the United States. Ultimately, the only reliable road to peace lies in nurturing and broadening friendly relations with nations that share the goal of destroying the threat posed by catastrophic weapons of mass murder and terror. 


\section{Acknowledgements}

I would like to thank my advisors at Oxford: Dr. Yuen Foong Khong for his invaluable guidance in sustaining and focusing this dissertation, and Dr. Steven Casey for his critical insights as the topic was taking form. I am also indebted to numerous individuals who were willing to give of their time and participate in interviews. Finally, I am grateful to my family for providing support and love that tempered the grim subject, reminding me why I am studying international relations in the first place. 


\section{$\underline{\text { Table of Contents }}$}

List of Abbreviations $\mathbf{v}$

Chapter 1. Introduction: Deterrence in a Modern Era 1

Chapter 2. Deterrence Theory and Its Flaws 21

Chapter 3. Deterrence with WMD: Crisis and Conflict with Iraq and North Korea 47

Chapter 4. Strategic Considerations and Counterproliferation Options 71

Chapter 5. Preemptive and Preventive War 96

Chapter 6. Modern Dilemmas: North Korea 124

Chapter 7. Recommendations and Conclusions 161

Bibliography 182 


\section{List of Abbreviations}

BW Biological Weapons

CB Chemical-Biological Weapons

CPRC Counterproliferation Program Review Committee

CW Chemical Weapons

DMZ De-Militarized Zone

DoD Department of Defense

DPRK Democratic People's Republic of Korea

GPS Global Positioning System

IAEA International Atomic Energy Agency

ICBM Intercontinental Ballistic Missile

LWR Light Water Reactor

MAD Mutually Assured Destruction

NMD National Missile Defense

NPT Non-Proliferation Treaty

NSS National Security Strategy

PSI Proliferation Security Initiative

TMD Theatre Missile Defense

UAV Unmanned Aerial Vehicle

UN United Nations

WMD Weapons of Mass Destruction 


\section{Chapter 1}

\section{Introduction: Deterrence in a Modern Era}

Once the cornerstone of U.S. strategy during the Cold War, deterrence theory is increasingly under fire in an age of proliferated weapons of mass destruction (WMD ${ }^{1}$ ). While concerns and skepticism over deterrence were never completely absent, the tragic events of 11 September 2001 crystallized doubts about its reliability. Though perpetrated by a non-state terrorist group, the crisis of confidence stemming from 11 September quickly extended to suspect—or "rogue" — - states as well, especially because state sponsorship of such organizations appeared to be growing. As President Bush remarked in a speech at West Point on 1 June 2002:

Deterrence-the promise of massive retaliation against nations-means nothing against shadowy terrorist networks with no nation or citizens to defend. Containment is not possible when unbalanced dictators with weapons of mass destruction can deliver those weapons on missiles or secretly provide them to terrorist allies. ${ }^{3}$

If not deterrence and containment, however, then what? For the past decade, the United States has been gradually developing a counterproliferation strategy based on the premise that deterrence is not enough and must be augmented by capabilities for protection and defense. ${ }^{4}$ In its most recent incarnation, dubbed the Bush Doctrine and articulated in the September 2002 National Security Strategy, there is a significant emphasis on offensive means to preemptively defeat prospective threats:

\footnotetext{
${ }^{1}$ While use of the collective term WMD is commonly understood and analytically practical, it carries the risk of overlooking important distinctions among nuclear, biological, and chemical weapons. I discuss such differences in greater detail later in this chapter.

${ }^{2}$ Similarly, many authors take issue with the fairly widespread practice of grouping worrisome states together with the descriptive but depreciatory adjective "rogue." Unfortunately, alternatives such as "states of concern" have failed to make their way into common usage, and a collective term is necessary. Please see "Defining Terms" section of this chapter for further detail. See also Eric Herring, "Rogue Rage: Can We Prevent Mass Destruction?" Journal of Strategic Studies vol. 23, no. 1 (March 2000): 188-212 and Robert S. Litwak, Rogue States and U.S. Foreign Policy: Containment after the Cold War (Baltimore, MD: Johns Hopkins University Press, 2000).

${ }^{3}$ George W. Bush, Graduation Speech, West Point, New York, 1 June 2002.

${ }^{4}$ National Defense University, The Counterproliferation Imperative: Meeting Tomorrow's Challenges

(Washington D.C.: November 2001), 2.
} 
We must be prepared to stop rogue states and their terrorist clients before they are able to threaten or use weapons of mass destruction against the United States and our allies and friends....Given the goals of rogue states and terrorists, the United States can no longer solely rely on a reactive posture as we have in the past. ${ }^{5}$

In a potentially self-reinforcing fashion, the question then becomes how these rogue states will respond to the gathering U.S. threat directed at them, particularly in light of Operation Iraqi Freedom. While one might hope that their leaders will choose moderate policies and renounce WMD, it appears more likely that they will seek to deter interference in their affairs by threatening and potentially initiating WMD attacks, either against troops on the battlefield, U.S. allies, or the American homeland itself. For instance, even though WMD were not employed in the 2003 conflict with Iraq, Saddam Hussein certainly obliquely threatened their use, and there was intense concern at the time over the likelihood and consequences of such action. ${ }^{6}$ As it turned out, the Iraqi arsenal was almost certainly illusory and there was nothing for the United States to deter, but that hardly inspires confidence for a similar resolution of such conflicts in the future. The growing destructiveness of rogue state capabilities, coupled with doubts over the restraint of desperate and unpredictable leaders, may lead U.S. officials to eventually back down from such confrontations given the inherent risks posed by a WMD-armed adversary. This has become a particularly salient point in the ongoing impasse with North Korea, as it appears that the Bush administration has all but ruled out harsh economic penalties or military strikes in response to likely advances in the North Korean

\footnotetext{
${ }^{5}$ U.S. Government, The National Security Strategy of the United States of America (Washington D.C.: September 2002), 14 and 15.

${ }^{6}$ James Dao, "Pentagon's Worry: Iraqi Chemical Arms," New York Times, 19 May 2002; Milton Viorst, "Imagining the Worst-Case Scenario in Iraq," New York Times, 12 September 2002; Bradley Graham, "'Scorched Earth' Plans in Iraq Cited," Washington Post, 19 December 2002; Philip Smucker, "Iraq Flexes its Military Trump Card," Christian Science Monitor, 19 March 2003; Greg Jaffe, "Intelligence Suggests Hussein Allowed Chemical-Weapon Use," Wall Street Journal, 20 March 2003; David E. Sanger, "U.S. Officials Fear Iraqis Plan to Use Gas on G.I.'s," New York Times, 25 March 2003; Jessica Guynn, "As Coalition Nears Baghdad, Chemical Arms a Question Mark," The Mercury News, 3 April 2003; Thomas Fuller, "Iraq Vows 'Unconventional' Tactics to Defend Capital," New York Times, 4 April 2003; Bill Gertz, "Coalition Still Wary of Chemical Weapons," Washington Times, 5 April 2003.
} 
nuclear program. This is in sharp contrast to a similar crisis a decade ago, when U.S. officials considered the reprocessing of plutonium a strict "red-line," meant to invite U.S. retaliation. Ultimately, it is impossible to predict how these security relationships will develop; deterrence is a two-way street, affecting both sides, and little is known about the "rules of the road" or who will yield to avoid collision.

This dissertation seeks to explore the nature of deterrence and counterproliferation in disputes between states that are asymmetric in military power but both in possession (or in likely possession) of WMD. ${ }^{7}$ It will consider U.S. action in regional crises and conflicts involving important interests, ranging from the reversal of local aggression to the destruction of terrorist camps and WMD facilities, or even the removal of an adversary's regime. A major premise is that deterrence is of decreasing reliability against rogue states, but of increasing potency against the United States. This is due to the fact that while some adversaries may be willing to run the risk of severe counterattack, America will become ever more reluctant to fight for non-vital matters under the shadow of catastrophic damage. To forestall this development, the United States is investing in counterproliferation programs and articulating a preventive war doctrine against threatening regimes, aiming to eliminate potential security threats before they fully materialize. These policies, while prudent in principle, will only be beneficial if tempered by a strategy that capitalizes on U.S. power and influence, but also recognizes its shortcomings and limitations. Otherwise, heavy-handed U.S. action will dramatically exacerbate the threats arrayed against it, quite possibly to the point where even the most ambitious counterproliferation efforts will fail.

\footnotetext{
${ }^{7}$ Non-state actors are of critical importance to my analysis as well, for they are likely to be the means to carry out a state-directed WMD attack and pose a very significant threat in and of themselves. However. I focus primarily on states because they are the most probable source of WMD, should be more susceptible to deterrence, and are a more fruitful target for academic research.
} 
At first glance, the proposition that the United States will need protective means to shield itself against and defeat a prospective rogue state WMD attack may appear rather intuitive and unobjectionable. ${ }^{8}$ However, according to traditional deterrence theory-developed during the bipolar era of mutually assured destruction between the superpowers-the sheer terrifying potential of weapons of mass destruction ought to make them suitable only for defensive purposes. ${ }^{9}$ In speaking of nuclear weapons, Kenneth Waltz claims: "[N]othing can be done with them other than to use them for deterrence." ${ }^{10}$ In a more imaginative illustration, Robert Sandoval muses:

With the defense of its borders entrusted to forces structured around the firepower of nuclear weapons, any nation not now a nuclear power, and not harboring ambitions for territorial aggrandizement, could walk like a porcupine through the forests of international affairs: no threat to its neighbors, too prickly for predators to swallow. ${ }^{11}$

Seemingly confirmed by the nearly half-century of peace during the Cold War, this formulation runs into two fundamental dilemmas in the post-Cold War era. First, there may be, or could be in the future, WMD "porcupines" in the world that do have ambitions for territorial aggrandizement; some states may use a mutually deterrent relationship to provide strategic cover for local aggression, a phenomenon referred to as the "stability-instability paradox." or even threatened, as long as it is enough of a possibility to make the expected costs of military action unacceptable to the United States. For example, in 1990 Saddam Hussein, "saw his extensive arsenal of mass destruction weapons, especially Iraq's

\footnotetext{
${ }^{8}$ The need for defense might seem particularly obvious in the wake of 11 September, the anthrax attacks, and other reported terrorist plots. It is worth noting, though, how different the U.S. strategic mindset was when I began this research in October 2000. Moreover, as explained in greater detail in Chapter Four, many analysts believe that the United States is still far from prepared to respond to a WMD attack.

${ }^{9}$ A.J.C. Edwards, Nuclear Weapons, the Balance of Terror, the Quest for Peace (London: Macmillan Press Ltd., 1986), 3.

${ }^{10}$ Kenneth N. Waltz, "Waltz Responds to Sagan," in Scott D. Sagan and Kenneth N. Waltz, The Spread of Nuclear Weapons: A Debate (New York: W.W. Norton \& Company, 1995), 98.

${ }^{11}$ Robert R. Sandoval, "Consider the Porcupine: Another View of Nuclear Proliferation," The Bulletin of the Atomic Scientists vol. 32, no. 5 (May 1976): 19.

${ }^{12}$ Robert Jervis, The Illogic of American Nuclear Strategy (Ithaca, NY: Cornell University Press, 1984), 29-34. The Soviet invasion of Afghanistan in 1979 is often cited as one example of this concept.
} 
known chemical weapon capacity, as a strategic umbrella to dissuade any foreign interference in his plans" for Kuwait. ${ }^{13}$

Further, while a state may not be overtly expansionist, the 11 September attacks sharpened the world's awareness toward the danger of allowing unstable or revolutionary regimes to harbor terrorist elements within their borders, plotting for the perfect opportunity to strike. Similarly, even if a state such as North Korea does not have direct links to terrorist networks, it might sell nuclear weapons on the black market that could eventually end up in the wrong hands. In these scenarios, traditional deterrence theory is far from conclusive, and mutual deterrence may be strained to the limits, especially if it results in an unacceptable policy outcome for the United States. Complete territorial sovereignty and protection from terrorist threats may at times be competing vital interests. In sum, deterrence is in a state of flux as regional powers attempt to employ WMD to neutralize American conventional weapon superiority, while the United States tries to avoid such vulnerability or overcome its repercussions. How to approach these dangerous situations, when the world community may simply not be able to leave the porcupines of the forest alone, is the main challenge this dissertation seeks to address.

\section{Deterrence: Then and Now}

Uncertainty regarding the concept of deterrence is not in any way due to its suffering from academic neglect. The Cold War provided an ideal bipolar context from which to explore bomber gaps, missile gaps, first-strike capabilities, counter-value strategies, and more. Over a generation of analysts devoted themselves to the challenge of keeping the Soviet military machine at bay, or defeating it if war broke out. ${ }^{14}$ There

\footnotetext{
${ }^{13}$ Avigdor Haselkorn, The Continuing Storm: Iraq, Poisonous Weapons, and Deterrence (New Haven, CT: Yale University Press, 1999), 19.

${ }^{14}$ Bernard Brodie, The Absolute Weapon: Atomic Power and World Order (New York: Harcourt, 1946); Henry Kissinger, Nuclear Weapons and Foreign Policy (New York: Harper \& Brothers, 1957); Robert
} 
are certainly many valuable lessons to be drawn from this period, most notably some of the basic tenets of deterrence theory itself. Nevertheless, the world is no longer a standoff of the titans; rather, it can be described as "a strange hybrid, a uni-multipolar system with one superpower and several major powers." ${ }^{15}$ In this strategic environment, conflict is much more likely to be between mismatched nations, as the United States confronts various weaker regional opponents. While each side can certainly harm the other, potentially severely, assured destruction is no longer mutual in quite the same way. Because of this, deterrence interactions will probably be unlike the past, and in need of a fresh examination.

Surprisingly, there has been very little academic attention given to the unique but crucially relevant deterrence relationship between asymmetric powers armed with WMD. Newspaper articles raising an alarm over the most recent foreign policy crisis appear from time to time, but few in-depth scholarly investigations with a historical, theoretical and prescriptive objective exist. More often than not, the literature in this field tends to focus primarily on a singular element, eschewing a more integrative approach. For instance, several important works have centered on the concept of asymmetry, investigating why weak states attack or defy the strong. ${ }^{16}$ These studies are quite useful for highlighting the importance of disparities in power and interest, but they have not been adequately extended to include the potentially transformative element of chemical,

Osgood, Limited War: The Challenge to American Security (Chicago: University of Chicago Press, 1957); Albert Wohlstetter, "The Delicate Balance of Terror," Foreign Affairs vol. 37, no. 2 (January 1959): 211234; Morton Halperin, Limited War in the Nuclear Age (Westport, CT: Greenwood Press, 1963); Wolfgang K.H. Panofsky, "The Mutual-Hostage Relationship Between American and Russia," Foreign Affairs vol. 52, no. 1 (October 1973): 109-118; Paul H. Nitze, "Deterring Our Deterrent," Foreign Policy no. 25 (winter 1976-77): 195-210.

${ }^{15}$ Samuel P. Huntington, "The Lonely Superpower," Foreign Affairs vol. 78, no. 2 (March/April 1999): 36 (italics his).

${ }^{16}$ Andrew Mack, "Why Big Nations Lose Small Wars: the Politics of Asymmetric Conflict," World Politics vol. XXVII, no. 2 (January 1975): 175-200; Yohanan Cohen, Small Nations in Times of Crisis and Confrontation (Albany, NY: State University of New York Press, 1989); Barry Wolf, When the Weak Attack the Strong: Failures of Deterrence, Rand Note (Santa Monica, CA: RAND, 1991); T.V. Paul, Asymmetric Conflicts: War Initiation by Weaker Powers (Cambridge: Cambridge University Press, 1994). 
biological, and nuclear weapons. It is unclear whether such arms will have a stabilizing effect on wartime bargaining or lead to even bolder risk-taking. Conversely, there are many authors concerned with the proliferation of WMD and its general effects on international security. ${ }^{17}$ Despite convincingly portraying the danger of nuclear catastrophe or rogue state blackmail, these efforts lack detailed case studies and do not sufficiently address the unique bargaining and brinksmanship tactics that take place between states with asymmetric power and interests in situations of crisis. Specifics of this nature are crucial to a full understanding of how deterrence works in practice, and to avoiding excessive speculation over how states might employ WMD.

Regional experts have produced several detailed histories and military analyses of rogue states and, given the typically secretive nature of these societies and regimes, such inside knowledge is indispensable to this dissertation. ${ }^{18}$ At the same time, in placing an investigative microscope over these apparently inscrutable leaders and

\footnotetext{
${ }^{17}$ Leonard S. Spector, with Jacqueline R. Smith, Nuclear Ambitions: The Spread of Nuclear Weapons 1989-1990 (Boulder, CO: Westview Press, 1990); Kathleen C. Bailey, Doomsday Weapons in the Hands of Many: The Arms Control Challenge of the 90s (Chicago: University of Illinois Press, 1991); Martin van Creveld, Nuclear Proliferation and the Future of Conflict (New York: The Free Press, 1993); William E. Burrows and Robert Windrem, Critical Mass: The Dangerous Race for Superweapons in a Fragmenting World (London: Simon \& Schuster Ltd., 1994).

${ }^{18}$ Adel Darwish and Gregory Alexander, Unholy Babylon: The Secret History of Saddam's War (London: Victor Gollancz Ltd., 1991); Kenneth Katzman, The Warriors of Islam: Iran's Revolutionary Guard (Oxford: Westview Press, Inc., 1993); Rick Atkinson, Crusade: The Untold Story of the Gulf War (London: Harper Collins Publishers, 1994); Michael J. Mazarr, North Korea and the Bomb: A Case Study in Nonproliferation (London: Macmillan Press Ltd., 1995); Michael R. Gordon and Bernard E. Trainor, The General's War (New York: Little, Brown and Company, 1995); Don Oberdorfer, The Two Koreas: A Contemporary History (London: Warner Books, 1997); Leon V. Sigal, Disarming Strangers: Nuclear Diplomacy with North Korea (Princeton, NJ: Princeton University Press, 1998); Anthony H. Cordesman, Iran's Military Forces in Transition: Conventional Threats and Weapons of Mass Destruction (Westport, CT: Praeger Publishers, 1999); Kongdan Oh and Ralph C. Hassig, North Korea: Through the Looking Glass (Washington D.C.: Brookings Institution Press, 2000); Said K. Aburish, Saddam Hussein, The Politics of Revenge (London: Bloomsbury, 2000); Andrew Cockburn and Patrick Cockburn, Out of the Ashes: The Resurrection of Saddam Hussein (London: Verso, 2000); Joseph S. Bermudez Jr., The Armed Forces of North Korea (New York: I.B. Tauris \& Co Ltd., 2001); Victor D. Cha, "Making Sense of the Black Box: Hypotheses on Strategic Doctrine and the DPRK Threat," in The North Korean System in the Post-Cold War Era, edited by Samuel S. Kim (New York: Palgrave, 2001); Kori N. Schake and Judith S. Yaphe, The Strategic Implications of a Nuclear-Armed Iran, McNair Paper No. 64 (Washington D.C.: Institute for National Strategic Studies, National Defense University, 2001); Anthony C. Cain, Iran's Strategic Culture and Weapons of Mass Destruction, Maxwell Paper No. 26 (Maxwell Air Force Base, AL: Air War College, April 2002); Shahram Chubin, Whither Iran? Reform, Domestic Politics and National Security, Adelphi Paper No. 342 (Oxford: Oxford University Press, International Institute for Strategic Studies, 2002).
} 
nations, the broader strategic consequences and theoretical implications of their WMD possession can be overlooked. Even a book that employs a wider scope, such as Robert Litwak's thorough and insightful Rogue States and U.S. Foreign Policy: Containment After the Cold War, is more concerned with critiquing America's sanctions-based strategy than uncovering how deterrence can best be strengthened for the future. ${ }^{19}$ Certainly there is a need for both country specific information and more general policy analysis, and this dissertation draws on each as necessary to make a critical assessment of the real world functioning of deterrence.

Closely related, other political scientists and psychologists have made significant contributions through their examination of the dynamics of leadership under pressure and the resulting potential for misperception and misjudgment. ${ }^{20}$ Deterrence is fundamentally a mental phenomenon, and thus any analysis of its potential failure ought to include elements such as emotions, biases, and cognitive disorders. However, this intersection of the fields of psychology and international relations has not been adequately explored, especially to incorporate the intensely stressful and disturbing potential of WMD use. Similarly, analyses of international terrorism are quite pertinent to the issue at hand, but they are not usually linked to the growing concern of state sponsorship and the utilization of terror for deterrence purposes. ${ }^{21}$ When faced with overwhelming U.S. military superiority, rogue states are very likely to turn to unconventional methods to carry out their goals or back up their threats. This potential for a symbiotic relationship of sub-state terror and state-level deterrence merits careful scrutiny.

\footnotetext{
${ }^{19}$ Litwak, Rogue States and U.S. Foreign Policy.

${ }^{20}$ Robert Jervis, Perception and Misperception in International Politics (Princeton, NJ: Princeton University Press, 1976); Irving L. Janis and Leon Mann, Decision Making: A Psychological Analysis of Conflict (New York: The Free Press, 1977).

${ }^{21}$ Marvin E. Wolfgang, International Terrorism (Beverly Hills, CA: Sage Publications, 1982); Jessica Stern, The Ultimate Terrorists (Cambridge, MA: Harvard University Press, 1999); Gary Ackerman and Laura Snyder, "Would They if They Could?" Bulletin of the Atomic Scientists (May/June 2002): 41-47.
} 
Further, in light of these real and growing dangers, international security experts have led a resurgence in counterproliferation research that aims to protect the United States through missile defenses, WMD detection devices, vaccines, or even preemptive strikes and preventive wars. ${ }^{22}$ This is a hugely important undertaking, but one which begs the question of whether traditional deterrence is satisfactory, and if it is not, how it is most likely to fail. Discovering the answers to these questions, which requires a combination of theoretical considerations and practical assessment, will be essential given finite resources for new military projects and acquisitions. Along these lines, there are several excellent works on the theoretical underpinnings of deterrence, as well as a few studies of the specific deterrent doctrines and strategies of rogue states. ${ }^{23}$ Unfortunately, while each of these aspects is an essential piece of the puzzle, there have been very few attempts to synthesize their insights and produce conclusions of both descriptive and prescriptive value. For example, Avigdor Haselkorn provides a brilliant and meticulous account of the WMD threats that occurred during the Gulf War in The

\footnotetext{
${ }^{22}$ Barry R. Schneider, Future War and Counterproliferation: U.S. Military Responses to NBC Proliferation Threats (Westport, CT: Praeger, 1999); Bernard I. Finel, "The Role of Aerospace Power in U.S. Counterproliferation Strategy," Aerospace Power Journal (winter 1999): 77-89; Biological Weapons: Limiting the Threat, edited by Joshua Lederberg (Cambridge, MA: The MIT Press, 1999); Prevailing in a Well-Armed World: Devising Competitive Strategies Against Weapons Proliferation, edited by Henry D. Sokolski (Carlisle, PA: Strategic Studies Institute, March 2000); Dean Wilkening, Ballistic-Missile Defence and Strategic Stability, Adelphi Paper No. 334 (Oxford: Oxford University Press, International Institute for Strategic Studies, 2000); James J. Wirtz and Jeffrey A. Larsen, Rockets Red Glare: Missile Defense and the Future of World Politics (Boulder, CO: Westview, 2001); James M. Lindsay and Michael E. O'Hanlon, Defending America: The Case for Limited National Missile Defense (Washington D.C.: Brookings Institution Press, 2001); The Gathering Biological Warfare Storm, edited by Jim A. Davis and Barry R. Schneider (Maxwell Air Force Base, AL: USAF Counterproliferation Center, April 2002); Michael A. Levi, Fire in the Hole: Nuclear and Non-Nuclear Options for Counterproliferation, Working Paper No. 31 (Washington D.C.: Carnegie Endowment for International Peace, November 2002); Robert S. Litwak, "The New Calculus of Pre-emption," Survival vol. 44, no. 4 (winter 2002-03): 53-80; Jason D. Ellis, "The Best Defense: Counterproliferation and U.S. National Security," The Washington Quarterly vol. 26 no. 2 (spring 2003): 115-133.

${ }^{23}$ Thomas C. Schelling, Arms and Influence (New Haven, CT: Yale University Press, 1966); Patrick M. Morgan, Deterrence: A Conceptual Analysis (Beverly Hills, CA: Sage Publications, 1977); Kenneth N. Waltz, The Spread of Nuclear Weapons: More May Be Better, Adelphi Paper No. 171 (London: International Institute for Strategic Studies, 1981); Edward Rhodes, Power and MADness: the Logic of Nuclear Coercion (New York: Columbia University Press, 1989). Shahram Chubin, Iran's National Security Policy: Intentions, Capabilities, \& Impact (Washington D.C.: Carnegie Endowment for International Peace, 1994); Timothy V. McCarthy, "Saddam's Toxic Arsenal: Chemical and Biological Weapons in the Gulf Wars," in Planning the Unthinkable, edited by Peter R. Lavoy, Scott D. Sagan, and James J. Wirtz (Ithaca, NY: Cornell University Press, 2000); Patrick M. Morgan, Deterrence Now (Cambridge: Cambridge University Press, 2003).
} 
Continuing Storm: Iraq, Poisonous Weapons, and Deterrence. ${ }^{24}$ To be able to apply these insights to other strategic interactions, though, the evidence presented must be integrated into a broader theoretical framework to obtain common lessons. Likewise, Keith Payne offers a compelling case for the inadequacy of deterrence theory, drawing upon historical examples and persuasive analysis in The Fallacies of Cold War Deterrence and a New Direction. ${ }^{25}$ In order to make his argument even stronger by backing up theory with practice, a solid link to contemporary examples of how states are actually practicing deterrence is necessary. This dissertation will attempt to bridge these two approaches, drawing from their strengths to build a logical argument that is also based on real world evidence.

As is apparent, its rich academic heritage notwithstanding, deterrence theory is in need of a scholarly reassessment in light of the collapse of the Soviet Union and the continued proliferation of WMD. In the United States, the Bush administration has correctly identified deterrence as an area of strategic uncertainty, but has put the cart before the horse by virtually declaring it a dead doctrine and pushing ahead with counterproliferation initiatives across the board. A crucial interim step is to clarify the likely conditions of deterrence failure and to be more country-specific regarding policy recommendations. Otherwise, the international community will label the Bush Doctrine a blunt tool of veiled aggression, inevitably inviting resistance from U.S. allies and retaliation from its adversaries.

In this sense, while the dissertation is primarily focused on the United States and has immediate relevance in crafting more practical counterproliferation options against rogue states, it has considerable import for American allies and adversaries, as well as international order more generally. According to Victor Utgoff, "If important U.S.

\footnotetext{
${ }^{24}$ Haselkorn, The Continuing Storm.

${ }^{25}$ Keith B. Payne, The Fallacies of Cold War Deterrence and a New Direction (Lexington, KY: The University Press of Kentucky, 2001).
} 
overseas interests are challenged by states newly armed with such weapons, the United States must choose between running sharply increased risks of defending its interests, or compromising those interests, together with its reputation for military preeminence and a willingness to protect allies and friends." 26 Of course, there will unavoidably be great disagreement over how free a hand the United States ought to have in intervening abroad, much of it depending on one's perspective. Limiting America's freedom of action might seem like a welcome development to those discontented with a perceived trend toward U.S. unilateralism. ${ }^{27}$ China, in particular, is worried that protection against coercion and blackmail, such as missile defenses, "will make the American military too brave, and that will be very, very dangerous for everyone." 28 Given the mixed record of U.S. foreign policy, including instances when America probably overstepped its bounds (as in Somalia) and many others when it should have done much more (as in Rwanda), this is an understandable concern. ${ }^{29}$

On the other side are those who rely on the United States for their security, or believe that only America has the military might capable of providing the backbone for international order and peace. ${ }^{30}$ The United States may not have an impeccable nationbuilding record, and it is often hypocritical when it comes to humanitarian intervention, but it still plays a major role in many peacekeeping operations and helps to keep some regional hotspots from flaring into war through mediation and security guarantees. To some, the prospect of the United States being deterred from responding to rogue state

\footnotetext{
${ }^{26}$ Victor A. Utgoff, "The Specter of Nuclear, Biological, and Chemical Weapons Proliferation," in The Coming Crisis: Nuclear Proliferation, U.S. Interests, and World Order, edited by Victor A. Utgoff (Cambridge, MA: MIT Press, 2000), 4.

${ }^{27}$ Stephen M. Walt, "Beyond Bin Laden: Reshaping U.S. Foreign Policy," International Security vol. 26, no. 3 (winter 2001-02): 60.

${ }^{28}$ Erik Eckholm, "Experts Try to Make Missile Shield Plan Palatable to China," New York Times, 28 January 2001.

${ }^{29}$ For a slightly charged account of America's past sins, see William Blum, Rogue State: A Guide to the World's Only Superpower (London: Zed Books, 2001).

${ }^{30}$ Charles Krauthammer, "The Unipolar Moment," Foreign Affairs vol. 70, no. 1 (1990-91): 25; Samuel Huntington, "Why International Primacy Matters," International Security vol. 17, no. 4 (spring 199.3): 82.
} 
provocations would mean a much more dangerous world, one in which regimes like the Taliban would remain in control of Afghanistan, providing a safe haven for Al Qaeda to continue to mastermind terrorist plots around the globe. Moreover, small, weak states are likely to be the most vulnerable if the United States is forced to retreat into a "Fortress America" mentality. ${ }^{31}$ Kuwait might not be a country today if America had not led the United Nations (UN) coalition to confront Iraq in 1990-91. Utgoff notes: “...the world needs at least one state, preferably several, willing and able to play the role of sheriff, or to be members of a sheriff's posse, even in the face of nuclear threats." 32 Indeed, Europe must make a similar strategic choice regarding how it will respond to states with factions or entire populations that hold virulent anti-Western views and weapons that can be used for blackmail or devastating covert attacks.

This dissertation will be of interest to readers of either perspective, since it will shed light on deterrence and how it is likely to affect U.S. foreign policy in both a positive and negative manner. Though there is an underlying motivating force of supporting U.S. interests, it is far from apparent what strategic doctrine will best serve that end. Richard Betts makes the astute observation that "American activism to guarantee international stability is, paradoxically, the prime source of American vulnerability." ${ }^{33}$ If the United States overreaches itself and gains a reputation as a unilateral bully, it is likely to find much needed international cooperation in peacekeeping and nation-building missions lacking as well as growing resistance to its policies. In sum, regardless of nationality or political affiliation, this topic is of central importance since all can agree that the United States is centrally involved as the one truly

\footnotetext{
${ }^{31}$ James R. Schlesinger, "The Strategic Consequences of Nuclear Proliferation," in Arms Control for the Late Sixties, edited by James E. Dougherty and J.F. Lehman Jr. (Canada: D. Van Nostrand Company, Inc., 1967), 175.

32 Victor A. Utgoff, "Proliferation, Missile Defence and American Ambitions," Survival vol. 44, no. 2 (summer 2002): 90.

${ }^{33}$ Richard K. Betts, "The New Threat of Mass Destruction," Foreign Affairs vol. 77, no. 1 (January/February 1998): 28.
} 
global power in world affairs and thus the extent to which it is active or deterred is of crucial relevance.

\section{Defining Terms}

Given that Cold War deterrence theory was so heavily dominated by considerations of the nuclear balance, it is worth remembering that other weapons are likely to take center stage during conflicts in the post-Cold War era. For instance, biological weapons (BW), toxins, chemical weapons $(\mathrm{CW})$, and radiological weapons are all capable of causing extreme damage, in some cases nearly on the scale of atomic detonations. Even certain conventional weapons, with exotic names like "fuel air explosives" or "thermobaric bombs" are beginning to have yields that rival nuclear blasts. ${ }^{34}$ At the same time, these weapons have significant differences that are important to note, especially regarding the ease with which they are weaponized and employed in wartime. Analysts often single out smallpox, for example, as an incredibly infectious biological agent that would be quite difficult to contain if released among a civilian population. ${ }^{35}$ As dangerous as this virus would be in the hands of a terrorist, it would be fairly difficult to use effectively in a tactical operation on the battlefield given the possibility of inoculation and the technical challenges involved in engineering a warhead that would not destroy its contents upon impact. Conversely, CW such as sarin and mustard gas, though not inherently as lethal as certain BW such as smallpox or anthrax, can nevertheless cause substantial fatalities if delivered efficiently in crowded environments. Overall, despite the important distinctions between different types of weapons, which I will note when relevant, for the purposes of this dissertation a

\footnotetext{
${ }^{34}$ Andre C. Revkin, "Advanced Armaments," New York Times, 3 December 2001.

${ }^{35}$ William J. Broad, Stephen Engelberg, and James Glanz, “Assessing Risks, Chemical, Biological, Even Nuclear," New York Times, 1 November 2001.
} 
collective term is needed and WMD offers a simple, commonly used, and analytically helpful shorthand.

An even more contentious debate over terminology persists due to the lack of a useful and widely accepted alternative to the somewhat pejorative term of "rogue states." Such an adjective is likely to conjure up negative connotations, leading to the implicit assumption that these states are aggressively inclined and do not adhere to the norms and rules of international relations. This is problematic not least because the list of "rogues" seems to be rather fluid, with today's friend quite easily becoming tomorrow's enemy, and vice-versa (as shown by Libya). As one commentator put it, "The reality is that whether a country is perceived as a threat or a rogue state or a member of the 'axis of evil' is more closely linked to whether countries are perceived to be friendly toward the United States than it is to a state's actual behavior or the actual threat it poses to international order."36 Moreover, states like Pakistan seem to straddle the boundary of the term, and others like Syria and Iran are clearly in a transitional phase that makes placing them in a collective category without differentiation a bit problematic.

Yet, as with the acronym WMD, a more general term is necessary for discussions of proliferation issues with a broad and theoretical perspective, and no substitute has taken hold in the literature. This does not mean I agree with the current U.S. classification, though it does include several states that have had a troubling track record in recent international affairs from any perspective. I use "rogue state" more as an analytic tool to describe states, present or in the future, who share certain characteristics such as an apparent penchant for aggression, links to terrorist networks, and an active interest in WMD. To balance objectives I will mention specific states whenever

\footnotetext{
${ }^{36}$ Pascal Boniface, "What Justifies Regime Change?" The Washington Quarterly vol. 26, no. 3 (summer 2003): 67.
} 
possible, but when appropriate use the term "rogue states," keeping in mind that this is an elastic grouping with a disputed membership.

\section{Method}

This is a challenging research topic because much of it is based on theoretical analysis and often sensitive or classified information. To start with, any study of deterrence, by its very nature, is not easily analyzed by empirical methods. ${ }^{37}$ It is a field based on alternative history that must "rely upon concepts, hypotheses and inferences not directly or fully tested." ${ }^{38}$ Given the lack of complete knowledge regarding how states perceive threats, it is impossible to definitively confirm when deterrence was successful in the past, much less how it will play out in the future. Indeed, there is no explicit way to prove or disprove my argument, other than providing a convincing case of how the strategic balance between the United States and rogue states is developing, and identifying the crucial variables behind such an evolution. Granted, if there were several instances of the United States charging into regional conflicts against WMD states without suitable counterproliferation assets-as would be the case if it attacked North Korea-then it would cast some doubt on my thesis. However, an isolated example such as Iraqi Freedom, or conversely the absence of relevant conflicts, should not bias the overall analysis in either direction. When discussing instances of WMD deterrence in particular, the relative lack of case studies means that it will be necessary to place significant weight on deductive reasoning rather than on calculations based on a large data set. $^{39}$

\footnotetext{
${ }^{37}$ Peter R. Lavoy, "The Strategic Consequences of Nuclear Proliferation: A Review Essay," Security Studies vol. 4, no. 4 (summer 1995): 698.

${ }^{38}$ Michael Quinlan, Thinking About Nuclear Weapons (London: Royal United Services Institute for Defence Studies, 1997), 3. See also Morgan, Deterrence Now, 121-128.

${ }^{39}$ Dean Wilkening and Kenneth Watman, Nuclear Deterrence in a Regional Context (Santa Monica, CA:

RAND, 1995), 2.
} 
While unavoidably theoretical and somewhat speculative, a rigorous and systematic investigation of deterrence can still yield important insights and conclusions. The groundbreaking work of George and Smoke, Deterrence in American Foreign Policy: Theory and Practice, employed counterfactual analysis of several historical examples of limited conflict to conclude that leaders often rely too heavily on outmoded concepts of deterrence. During the Korean War, U.S. leaders failed to realize that their attempts to reassure the Chinese of their peaceful intentions were completely at odds with MacArthur's offensive toward the Yalu River. A "double failure of deterrence" was the result of flawed signaling, poor intelligence, and incompatible security objectives, leading to a war that neither side wanted and both tried to avoid. ${ }^{40}$ Unwilling to settle for a general theory with uncertain practical relevance, George and Smoke sought to develop "contingent generalizations" that would identify causal patterns and thereby offer some assistance to policy makers through prognosis and prediction rather than extensive prescription. This dissertation likewise eschews an all-encompassing theory of the functioning of deterrence and instead recognizes that it is best to illuminate such a complex topic by analyzing how it is likely to function under specific conditions in the future based on how it has in the past.

Even when real-world evidence is somewhat scarce, hypothetical scenarios and conceptual illustrations can be very useful for understanding the logic and assumptions of certain principles. Thomas Schelling relied almost exclusively on game theoretical situations and invented examples to make his argument in The Strategy of Conflict. For instance, to explain the concept of tacit coordination, Schelling described a fictional situation wherein two parachute jumpers land in an unknown area, possessing maps but no means of communicating with one another. Needing to rendezvous in order to be

\footnotetext{
${ }^{40}$ Alexander L. George and Richard Smoke, Deterrence in American Foreign Policy: Theory and Practice (New York: Columbia University Press, 1974), 184-234.
} 
rescued, the two jumpers should be able to rely on intuitive focal points to find one another despite the lack of a predetermined meeting place. ${ }^{41}$ Beyond just a clever narrative, the story provides an easily accessible way of explaining how actors in a bargaining situation can act in concert as long as there are some convergent interests involved. This dissertation will also draw on Schelling's model, exploring contemporary case studies but equally supporting much of its analysis with historical references, hypotheticals, and evidence from psychological research.

The point is not that such methods are the preferred mode of academic inquiry, but merely that certain subjects merit detailed investigation even if all of the conclusions drawn cannot be definitively proven one way or the other. In the words of Peter Feaver, even if Rational Decision Theory (RDT) held $99.5 \%$ of the time, "this would qualify RDT for the social science theory hall of fame, but it would not make nuclear proliferation trivial." 42 Nor would it make the research into the causes and effects of WMD proliferation inconsequential. On balance, the better our understanding of the dynamics of deterrence involving WMD, the safer and more secure we will be. Toward that end, this dissertation follows the method of works such as Halperin's Limited War in the Nuclear Age, which sought to explain past events, predict the likely evolution of conflict, and distill recommendations for American policymakers. ${ }^{43}$ Just as Halperin challenged the reliance on the doctrine of massive retaliation to deter a Soviet conventional attack, so this dissertation will challenge the reliance on a similar doctrine of massive retaliation to deter a rogue state's WMD attack. It will also investigate various counterproliferation options for reducing this reliance, paying special attention to the evolving doctrine of pursuing preventive war to destroy prospective threats.

\footnotetext{
${ }^{41}$ Thomas C. Schelling, The Strategy of Conflict (Cambridge, MA: Harvard University Press, 1960), 5458.

${ }^{42}$ Peter D. Feaver, "Proliferation Optimism and Theories of Nuclear Operations," Security Studies vol. 2, nos. 3 and 4 (spring/summer 1993): 162.

${ }^{43}$ Halperin, Limited War in the Nuclear Age, viii.
} 
Finally, it is worth noting that even the most highly classified subject areas deserve discussion in an open forum. Millions of people are affected by decisions over national security, and scholars can generally analyze the most pertinent issues without access to sensitive intelligence. For this topic, there were a sufficient number of leaked insider accounts, government studies, and various secondary sources to support academic scholarship. This was certainly the case in the historical examples of WMD deterrence, where the participating government officials were quite candid in offering their perspective on events in personal memoirs, speeches, and interviews. While some relevant public figures still hold public office and were therefore reluctant or unavailable to be interviewed personally, it was generally possible to reach retired colleagues or analysts familiar with the background of U.S. policy choices. Newspaper reports, editorials, and journal articles also proved invaluable in rounding out certain details and uncovering new sources, documents, and information. Even though it may not be feasible to confirm examples of deterrence success, due to the imperfect knowledge of intentions, there is much to learn from how decisionmakers acted, communicated, and reflected afterward about crises. Conversely, deterrence failures are obviously much more concrete and therefore subject to greater scrutiny and analysis. All of these strands of research combine to create a more informed picture of the contemporary state of deterrence, forming the basis for policy recommendations and more general conclusions about strategy.

\section{Organization}

This dissertation will first introduce some of the traditional concepts of deterrence theory in Chapter Two, outlining several of its basic assumptions and reviewing the history of nuclear strategy. Chapter Two will also reveal some potential 
flaws in the theoretical construct of deterrence, cataloguing examples of extreme risktaking, explaining the influence of asymmetries of interest and psychological effects, and analyzing the special challenges posed by last resort threats and millenarian regimes. With this foundation, Chapter Three will then examine contemporary evidence of asymmetrical WMD deterrence, focusing in particular on the capabilities, doctrine, and behavior in the 1990-91 Gulf War and the 1993-94 crisis between the United States and North Korea. I selected these cases because they are the most significant of a very small subset of instances when the United States used or contemplating using force against a regional power suspected of possessing WMD. Other crises with Iran, Syria, and Libya all merit some analysis, but lack the same level of seriousness and explicit deterrent threats. With North Korea and Iraq, I will draw on the theoretical literature to explain why deterrence failed, may have failed, or succeeded in each case.

Next, Chapter Four will address how the proliferation of WMD is affecting international security, considering in particular whether Cold War conceptions of deterrence and containment are still applicable in the modern era. It will also analyze various counterproliferation options available to U.S. policymakers in coping with the declining utility of deterrence by examining the prospects for nonproliferation, active defenses, homeland security, and counterforce operations. Faced with the possibility that traditional counterproliferation may be inadequate to cope with new threats, Chapter Five will delve more deeply into the dilemmas posed by preemptive and preventive war, exploring their historical and legal foundations as well as the strategic ramifications of the Bush Doctrine. Especially in the wake of Iraqi Freedom, the consideration of how to place boundaries on the scope of U.S. military action is of prime importance. Chapter Six will then develop a strategic profile of North Korea, applying the factors introduced in Chapter Five to a real-world example. It will analyze possible motivations behind 
North Korea's nuclear program, illustrate the severe constraints on U.S. options, and describe the bargaining posture most suitable for resolving the crisis. Finally, Chapter Seven will draw some general conclusions and provide recommendations as to what specific policies and broader strategies would be most appropriate in responding to the developing global environment marked by the proliferation of WMD. 


\section{Chapter 2}

\section{Deterrence Theory and Its Flaws}

Deterrence as a concept is hardly new, dating back even to the Babylonian Code of Hammurabi in $17^{\text {th }}$ Century B.C., when virtually any serious crime was punishable by death. ${ }^{1}$ In fact, threats of retaliation and punishment are a feature of every day life, from parents attempting to discipline their children to statesmen haggling over the details of a treaty. In the words of Thomas Schelling: "Nations, like people, are continually engaged in demonstrations of resolve, tests of nerve, and explorations for understandings and misunderstandings." ${ }^{2}$ Given its ubiquitous presence, it is not surprising to discover that deterrence has attracted great interest from scholars and policymakers alike. This chapter will present the classic formulation of deterrence theory, its historical context, and its potential shortcomings.

\section{Basic Concepts}

Deterrence is a complicated term that traditionally means persuading an opponent that the costs of a particular action will outweigh any potential benefits. ${ }^{3}$ The aspect of persuading an opponent alludes to the psychological nature of deterrence, often an interplay of uncertain promises and threats that may be bluffs or firm commitments. According to the official U.S. Department of Defense definition, "Deterrence is a state of mind brought about by the existence of a credible threat of unacceptable counter

\footnotetext{
${ }^{1}$ Jean-Louis Gergorin, "Deterrence in the Post-Cold War Era," in The Use of Force: Military Power and International Relations, edited by Robert J. Art and Kenneth N. Waltz, $4^{\text {th }}$ edition (Lanham, MD: University Press of America, 1993), 447.

${ }^{2}$ Thomas C. Schelling, Arms and Influence (New Haven, CT: Yale University Press, 1966), 93.

${ }^{3}$ Alexander L. George and Richard Smoke, Deterrence in American Foreign Policy: Theory and Practice (New York: Columbia University Press, 1974), 11.
} 
action."4 Also, the word potential highlights the future-oriented nature of any deterrent threat, promising a certain reaction only in response to the undesired choice of another actor. If, on the other hand, a form of punishment is administered until the other side acts, rather than if it acts, scholars normally label the strategy as compellence. ${ }^{5}$ This difference is significant because while an adversary facing a deterrent threat can pretend that it never intended to act in the first place, compliance with a compellent threat often involves open submission to specific demands of the compeller, and thus may inflict greater costs on the opponent for giving in. ${ }^{6}$

Another important distinction regards the offensive or defensive nature of the response to an adversary's action. Glenn Snyder explains: "Essentially, deterrence means discouraging the enemy from taking military action by posing for him a prospect of cost and risk outweighing his prospective gain. Defense means reducing our own prospective costs and risks in the event that deterrence fails."7 Obviously the two can be combined, and a robust defense is likely to make a deterrent threat especially menacing. Similarly, theorists distinguish between deterrence based on denial and that based on punishment. One state's strategy of denial will attempt to convince an adversary that he is unlikely to achieve his objective; whereas a strategy of punishment will threaten to destroy something the opponent values greatly. ${ }^{8}$ Deterrence can also be based on positive inducements rather than merely negative consequences: reassurance is a tactic where one seeks to convince an adversary of one's benign intentions, hoping to forestall

\footnotetext{
${ }^{4}$ Quoted in Keith B. Payne, "Deterring the Use of Weapons of Mass Destruction: Lessons from History," Comparative Strategy vol. 14, no. 4 (October-December 1995): 347.

${ }^{5}$ Schelling, Arms and Influence, 70.

${ }^{6}$ Dean Wilkening and Kenneth Watman, Nuclear Deterrence in a Regional Context (Santa Monica, CA: RAND, 1995), 68.

${ }^{7}$ Glenn Snyder, "Deterrence and Defense," in The Use of Force, edited by Art and Waltz, 350.

${ }^{8}$ Wilkening and Watman, Nuclear Deterrence in a Regional Context, 9.
} 
aggressive action; conciliation involves offering rewards to an opponent in order to achieve the same result. ${ }^{9}$

Finally, deterrence theory draws important distinctions between general and immediate deterrence, and central and extended deterrence. ${ }^{10}$ General deterrence refers to a rivalry between states that may lead one side to anticipate potential enemies and seek to change the overall balance of power, but rarely includes overt military threats. By contrast, immediate deterrence consists of a challenger making an explicit threat to use military force and the defender attempting to dissuade the opponent from attacking by threatening some form of reprisal. Central deterrence describes the familiar Cold War relationship where each superpower seeks to prevent nuclear attacks on their homeland, whereas extended deterrence involves attempts to protect regional allies from war. Again, any real world cases will likely involve a mixture of all of these categories. During the 1990-91 Gulf War, for instance, the United States was concerned about direct attacks on American cities, as well as missile strikes against Israel and Saudi Arabia. Though the lack of functioning Intercontinental Ballistic Missiles (ICBMs) limits most rogue states to threatening regional targets, their capacity for state-sponsored international terrorism involving WMD requires a consideration of both central and extended deterrence.

\section{Deterrence Strategies}

Underlying any deterrent threat are the closely intertwined concepts of capability and credibility. While capability is reasonably straightforward and quantifiable, based

\footnotetext{
${ }^{9}$ David Garnham, Deterrence Essentials: Keys to Controlling an Adversary's Behavior (Abu Dhabi: Emirates Center for Strategic Studies and Research, 1995), 8.

${ }^{10}$ This section is drawn from Herman Kahn, On Thermonuclear War (Princeton, NJ: Princeton University Press, 1969), 126-144; Patrick M. Morgan, Deterrence: A Conceptual Analysis (Beverly Hills, CA: Sage Publications, 1977), Ch. 2; Kenneth Watman and Dean Wilkening, with John Arquilla and Brian Nichiporuk, U.S. Regional Deterrence Strategies (Santa Monica, CA: RAND, 1995), 13-15; and Patrick M. Morgan, Deterrence Now (Cambridge: Cambridge University Press, 2003), 80-115.
} 
on the military force that a state can bring to bear in a conflict, credibility is a much more fluid and qualitative variable, stemming from the probability that such force will be used. For instance, a state may have very formidable armed forces, but if it is bound by domestic opinion to use them only in defense of the homeland, any strategy of extended deterrence will lack credibility. According to Scott Sagan, credibility is based on a wide range of components including the perceived interests at stake, one's reputation for following through on threats, the legitimacy of the conflict, and the so-called "audience costs" of backing down. ${ }^{11}$ As this list makes clear, indeterminate factors such as value judgments and subjective assessments are at the heart of credibility, underscoring its protean nature. For instance, Watman and Wilkening point out that a state's reputation will decay quickly and tends to be specific to a given leader, a particular type of interest, and a particular type of warfare. ${ }^{12}$ As a result, one can never be sure that a deterrent threat is adequate, even if there is one hundred percent certainty in the mind of the deterrer; it is always possible that the opposing side will misperceive the credibility of a threat. Despite these difficulties, theorists have tried to develop strategies that are most likely to foster credibility, and a few significant aspects are discussed below.

To reinforce the perception of one's resolve, a common tactic is to employ commitment techniques that increase the costs of failing to act. This is akin to announcing publicly that one is about to go on a diet so that friends will act as a constant source of pressure to maintain the obligation. In the jargon of deterrence theory, making such a pledge imposes "audience costs" on oneself in the event of reneging on the promise. In a more dramatic illustration, the military image of "burning bridges" to make retreat impossible is the classic example of cementing one's resolve. As Thomas

\footnotetext{
${ }^{11}$ Scott D. Sagan, "The Commitment Trap: Why the United States Should Not Use Nuclear Threats to Deter Biological and Chemical Weapons Attacks," International Security vol. 24, no. 4 (spring 2000): 98. For a further explanation of audience costs, see the following paragraph.

${ }^{12}$ Watman and Wilkening, U.S. Regional Deterrence Strategies, xi.
} 
Schelling put it: "What we have to do is get ourselves into a position where we cannot fail to react as we said we would—where we just cannot help it—or where we would be obliged by some overwhelming cost of not reacting in the manner we had declared."13 The American decision to post troops in Western Europe as a "tripwire" against Soviet aggression was one instance of bolstering resolve, with the United States making the defense of Europe a more certain prospect by effectively denying itself the opportunity of retreat and abandonment.

The idea that denying oneself options can actually be beneficial may seem counterintuitive at first. Schelling describes this phenomenon as a "...paradox that the power to constrain an adversary may depend on the power to bind oneself."14 Considering the game of "chicken" may help to clarify this concept. If two drivers are about to start accelerating toward one another, it would send a powerful message if one driver chose to throw his steering wheel out the window. The other driver would then have no choice but to concede the contest or suffer catastrophe. Of course, while this technique can be a very effective way of enhancing resolve where interests or capability are lacking, the hidden danger is that it is always possible that both drivers will make the same decision, locking in an even worse outcome than if the position had been surrendered at the outset. ${ }^{15}$ The crucial factor, then, will be who is able to make the first move, leaving the other with the only "last clear chance" to avoid calamity. ${ }^{16}$

Finally, beyond committing oneself to a particular course, there is the tactic of issuing a "threat that leaves something to chance," wherein the final decision of whether to act is not altogether under the threatener's control. ${ }^{17}$ This is a gambling technique that

\footnotetext{
${ }^{13}$ Schelling, Arms and Influence, 43.

14 Thomas C. Schelling, The Strategy of Conflict (Cambridge, MA: Harvard University Press, 1960), 22.

${ }^{15}$ Stephen Maxwell, Rationality in Deterrence, Adelphi Paper No. 50 (London: International Institute for Strategic Studies, 1968), 4.

${ }^{16}$ Herman Kahn, Thinking About the Unthinkable (London: Weidenfeld and Nicolson, 1962), 46.

${ }^{17}$ Schelling, The Strategy of Conflict, 188.
} 
plays on the factor of risk-acceptance, assuming that the opposing side will choose to give in first. The classic image is of one person rocking a boat in order to elicit concessions from the other frightened occupants. Schelling uses the term brinksmanship to describe this strategy, the choice of "deliberately letting the situation get somewhat out of hand, just because its being out of hand may be intolerable to the other party and force his accommodation." 18 In keeping with the "chicken" scenario, this would be akin to one driver publicly consuming a large amount of alcohol before stepping into the car, creating doubt in his opponent's mind that he would be able to avoid collision even if he ultimately desired to do so. In the literature on deterrence, this phenomenon is called the "rationality of irrationality," since one can draw coercive power from the prospect of being potentially undeterrable. ${ }^{19}$ Once again, while this can be a particularly potent strategy, it courts disaster by embracing irrationality even though the opponent may have done the same or is fully expecting rational behavior in the crisis. Overall, despite the techniques that play out so well in game theory and hypothetical examples, it is always important to remember that deterrence is fundamentally about credibility and its roots in capability and resolve.

\section{Deterrence Theory in the Cold War}

Nuclear weapons were first used as an instrument of compellence to end World War II. The bomb dropped on Hiroshima on 6 August 1945 killed 66,000 people immediately and tens of thousands more afterward, ultimately resulting in Japan's surrender to the Allies. ${ }^{20}$ As the Cold War began and the Soviet Union joined the nuclear club in 1949, the United States faced a threat to its homeland it had never

\footnotetext{
${ }^{18}$ Ibid., 200.

${ }^{19}$ Edward Rhodes, Power and MADness: the Logic of Nuclear Coercion (New York: Columbia University Press, 1989), 16.

${ }^{20}$ Lawrence Freedman, The Evolution of Nuclear Strategy, $2{ }^{\text {nd }}$ edition (London: Macmillan Press Ltd., in association with the International Institute of Strategic Studies, 1989), xv.
} 
experienced before. In response, America began to focus more on deterrence, though this strategy went through endless cycles of reformulation, beginning with Eisenhower and John Foster Dulles' doctrine of massive retaliation, enunciated in 1954. Based on the premise that local defense was impossible against the overwhelming communist advantage in land power, Dulles argued that the United States should rely on strategic retaliation at places of its own choosing. ${ }^{21}$ The difficulty with this position was that the Soviet Union was not dependent solely on its ground forces but was developing a formidable nuclear arsenal as well, resulting in a relationship that Donald Brennan coined as "mutually assured destruction," or MAD. ${ }^{22}$ Many academics and policymakers questioned the credibility of American reliance on a nuclear response to a conventional attack, especially when the Soviets could retaliate in kind. ${ }^{23}$ Richard Betts humorously remarked: "In a competition in risk taking, why should Americans do better at Russian roulette than the Russians?"24 Eventually, Dulles phased out massive retaliation in 1957, though the dilemma of providing for the security of Europe remained. ${ }^{25}$

Put simply, the worry was that the superpowers' strategic arsenals would cancel each other out, enabling the Soviet Union to take advantage of its conventional superiority, most likely through limited advances-called "salami tactics"-that would aggregate into significant gains. ${ }^{26}$ Dubbed the "stability-instability" paradox, American strategic doctrine attempted to square this strategic circle by oscillating between a reliance on $\mathrm{MAD}$ and the development of war-fighting capabilities that would make even

\footnotetext{
${ }^{21}$ John Foster Dulles, "Massive Retaliation," in The Use of Force, edited by Art and Waltz, 371.

${ }^{22}$ Wolfgang K.H. Panofsky, "The Mutual-Hostage Relationship Between American and Russia," Foreign Affairs vol. 52, no. 1 (October 1973): 109.

${ }^{23}$ Robert Osgood, Limited War: The Challenge to American Security (Chicago: University of Chicago Press, 1957); Morton Halperin, Limited War in the Nuclear Age (Westport, CT: Greenwood Press, 1963); Robert Powell, Nuclear Deterrence Theory (Cambridge: Cambridge University Press, 1990), 13.

${ }^{24}$ Richard Betts, Nuclear Blackmail and Nuclear Balance (Washington D.C.: Brookings Institution, 1987), 13.

${ }^{25}$ Bernard Brodie, Strategy in the Missile Age (Princeton, NJ: Princeton University Press, 1959), 262.

${ }^{26}$ Henry Kissinger, Nuclear Weapons and Foreign Policy (New York: Harper \& Brothers, 1957), 134;

James J. Wirtz, "Counterproliferation, Conventional Counterforce and Nuclear War," Journal of Strategic Studies vol. 23, no. 1 (March 2000): 14.
} 
conventional aggression a dangerous prospect for the Soviets. ${ }^{27}$ Not to be outdone in the battle of the acronyms, critics of strategies that relied on options such as tactical nuclear weapons to fight a "credible" war against the Soviets labeled this idea "nuclear utilization theory," or NUTs. ${ }^{28}$

U.S. strategic thinkers were never quite able to achieve consensus on how to resolve this dilemma, simultaneously worrying that too much reliance on MAD would lack credibility, whereas too much confidence in fighting a "limited" conflict against the Soviets might actually increase the chance of war by making it easier to contemplate and plan for. ${ }^{29}$ Over the decades, successive administrations rehashed old concepts, from Dulles' New Look and McNamara's Flexible Response, to the Schlesinger Doctrine and Brown's Countervailing Strategy. From time to time, some policymakers even brought up missile defense as a potential solution to the uneasy state of MAD. Ultimately, a compromise incorporating elements of each strand of thought was adopted, placing a "trip-wire" force in Europe that would fight conventionally, and if defeated would trigger a broader strategic response. ${ }^{30}$ While not resolving the underlying dilemma-since this tripwire force could not succeed in large-scale battle and the resulting nuclear attack would still devastate Europe-this strategy nevertheless contained enough of an irreversible commitment to fight to create a significant likelihood in the minds of the

\footnotetext{
${ }^{27}$ Robert Jervis, The Illogic of American Nuclear Strategy (Ithaca, NY: Cornell University Press, 1984), 29-34.

${ }^{28}$ Spurgeon M. Keeny Jr. and Wolfgang K. H. Panofsky, "MAD Versus NUTS: Can Doctrine or Weaponry Remedy the Mutual Hostage Relationship of the Superpowers?" Foreign Affairs vol. 60, no. 2 (winter 1981-82): 289; Eric Mlyn, "U.S. Nuclear Policy and the End of the Cold War," in The Absolute Weapon Revisited: Nuclear Arms and the Emerging International Order, edited by T.V. Paul, Richard J. Harknett, and James J. Wirtz (Ann Arbor, MI: Michigan University Press, 1998), 192.

${ }^{29}$ G. W. Rathjens, "Flexible Response Options," Orbis vol. 18, no. 3 (fall 1974): 680; Lynne Etheridge Davis, "Limited Nuclear Options: Deterrence and New American Doctrine," in Strategic Deterrence in a Changing Environment, edited by Christoph Bertram (London: International Institute for Strategic Studies, 1981), 52.

${ }^{30}$ Michael Quinlan, Thinking About Nuclear Weapons (London: Royal United Services Institute for Defence Studies, 1997), 21.
} 
Soviets that a nuclear counter-attack would occur despite its consequences and apparent "irrationality."31

Fortunately, the superpowers never had to play out this "doomsday" scenario, and today the threat of a Soviet conventional attack on Europe has all but disappeared. Many in U.S. policy circles claim that since "deterrence has been proven to work" during the Cold War, concern over rogue states acquiring WMD is misplaced. ${ }^{32}$ In the words of U.S. Representative Cynthia McKinney: "Clearly if our nuclear arsenal and conventional military superiority deterred the Soviet Empire, it can do the same to Korea or Iraq."33 However, given the experience of Hungary, Czechoslovakia and Afghanistan, not to mention the scare during the Cuban Missile Crisis, it is difficult to argue that such recent history has raised deterrence to an "iron law." The fundamental dilemmas posed by the stability-instability paradox remain, and the answers are no more certain than before. The following section will address the factors that raise doubt about the continued applicability of "Cold War deterrence."

\section{Challenges to Deterrence}

On the face of it, nuclear deterrence has a simplicity that is quite compelling: the United States can promise certain and devastating retaliation in response to a WMD attack, and since no one in their right mind could tolerate such an outcome, the reliability of deterrence should hardly be at risk. This is the basic logic that Kenneth Waltz invokes when he offers the assurance that "not much is required to deter." 34 In fact, many

\footnotetext{
${ }^{31}$ Robert Jervis, “Why Nuclear Superiority Doesn't Matter," Political Science Quarterly vol. 94, no. 4 (winter 1979-80): 624.

${ }^{32}$ Kathleen C. Bailey, Doomsday Weapons in the Hands of Many: The Arms Control Challenge of the 90s (Chicago: University of Illinois Press, 1991), 80.

${ }^{33}$ Cynthia McKinney, "Should the U.S. Have a Missile Defense System?" American Legion Magazine vol. 148, no. 1 (January 2000): 42.

${ }^{34}$ Kenneth N. Waltz, "More May be Better," in Scott D. Sagan and Kenneth N. Waltz, The Spread of Nuclear Weapons: A Debate (New York: W.W. Norton \& Company, 1995), 22.
} 
scholars are so supremely confident in the power of deterrence that they speak of it "with the reverence of a physical principle," a universal and timeless formulation that applies in any and all places. ${ }^{35}$ Much of deterrence theory treats the concepts of capability and credibility like variables in a math equation that can be adjusted to somehow guarantee deterrence. Where credibility is lacking, increasing the level of force that can be brought to bear will compensate. Bruce Bueno de Mesquita and William Riker, for example, assume that once states can cause "unacceptable losses" to one another, the prospect of conflict virtually disappears, apparently regardless of the interests at stake. ${ }^{36}$ Conversely, if the amount of military power available is unconvincing, commitment techniques can help to eliminate doubt over one's willingness to act. To these theorists, all that is needed is sensible leadership to strike this balance and the compelling logic of deterrence will do the rest.

What is more, some scholars often apply this confidence in deterrence across the spectrum of conflicts against any adversary the United States may encounter. Kenneth Waltz again asserts: "Even the most troublesome and cruel leaders have shown themselves susceptible to deterrence."37 The U.S. Strategic Command seems to agree, claiming: "Leaders of 'rogue' states armed with WMD are not undeterrable, contrary to what many people argue." 38 The desire to simplify deterrence theory is understandable; grouping adversaries and relying upon certain assumptions has enormous predictive and

\footnotetext{
${ }^{35}$ Ken Booth, Strategy and Ethnocentrism (London: Croom Helm Ltd., 1979), 41; Richard Rosencrance, "Strategic Deterrence Reconsidered," in Strategic Deterrence in a Changing Environment, edited by Bertram, 7; William C. Martel, "Deterrence and Alternative Images of Nuclear Possession," in The Absolute Weapon Revisited, edited by Paul, Harknett, and Wirtz, 215.

${ }^{36}$ Bruce Bueno de Mesquita and William H. Riker, "Selective Nuclear Proliferation," Journal of Conflict Resolution vol. 26, no. 2 (June 1982): 287.

${ }^{37}$ Kenneth N. Waltz, “A Reply," Security Studies vol. 4, no. 4 (summer 1995): 804.

${ }^{38}$ Hans Kristensen, Nuclear Futures: Proliferation of Weapons of Mass Destruction and U.S. Nuclear Strategy (London: British American Security Information Council, March 1998), 31.
} 
prescriptive power. ${ }^{39}$ Doing so enables policymakers to downplay the more complicated task of investigating who is being deterred and instead merely ensure that the American arsenal is terrifyingly decisive. At the same time, one must also consider that these WMD capabilities must have some substantial value to rogue nations or they would not go through the risk and expense of their development. For instance, while it is unclear whether Iraq actually retained or hid anything, Saddam Hussein was willing to forgo \$15 billion a year in oil revenues in order to defy arms inspectors. ${ }^{40}$ Many of these states are likely to see WMD as the only way to win a regional conflict; either by threatening their use to avoid battle altogether or by using them to prevail in an asymmetric fashion. ${ }^{41}$ The rest of this chapter will investigate the theoretical and historical reasons to maintain a healthy skepticism toward deterrence, exploring asymmetries of interest and risktaking, commitment tactics, psychological effects and the rationality of the irrational, last resort attacks, and millenarian regimes.

Asymmetries of Interest and Running Risks: One major flaw of deterrence theory is that it posits a rational actor and then makes the assumption that a "rational" actor could never choose to risk its own destruction. This overlooks the fact that when a WMD threat is first being made, the opponent may sincerely believe that the United States will be deterred and it will never have to make good on its threat. After all, there is an important difference between running the risk of attack and actually suffering one; such a bet may not necessarily be irrational. ${ }^{42}$ To be effective, there really only has to be

\footnotetext{
${ }^{39}$ Keith B. Payne and Lawrence R. Fink, "Deterrence Without Defense: Gambling on Perfection," Strategic Review vol. XVII, no. 1 (winter 1989): 27-28; Edward Rhodes, Power and MADness: the Logic of Nuclear Coercion, 14.

${ }^{40}$ Philip Gordon, "Bush, Missile Defence and the Atlantic Alliance," Survival vol. 43, no. 1 (spring 2001): 23; Edward M. Spiers, Weapons of Mass Destruction: Prospects for Proliferation (London: Macmillan Press Ltd., 2000), 39.

${ }^{41}$ Robert G. Joseph, "The Role of Nuclear Weapons in U.S. Deterrence Strategy," in Deterrence in the $21^{\text {st }}$ Century, edited by Max G. Manwaring (London: Frank Cass \& Co., Ltd., 2001), 54.

${ }^{42}$ Wilkening and Watman, Nuclear Deterrence in a Regional Conflict, 3; T.V. Paul, Asymmetric Conflicts: War Initiation by Weaker Powers (Cambridge: Cambridge University Press, 1994), 174; Charles L. Glaser and Steve Fetter, "National Missile Defense and the Future of U.S. Nuclear Weapons Policy,"
} 
a chance that the WMD threat will be carried out, the magnitude of the consequences of which will make an assessment of "probably not" become "possibly yes" in the mind of U.S. planners. ${ }^{43}$ In this light, it is important to distinguish between rationality and reasonableness; there is a dangerous tendency to mold the term rational into the antonym of reckless, confusing what states should do with what they will do. ${ }^{44}$ Ken Booth offers a reminder of the experience of kamikaze pilots during WWII to stress that often times reasonable behavior is just what we are used to and that there is an "...almost universal assumption that it is always the next person who is crazy." ${ }^{, 45}$ Merely taking large risks is not irrational, per se; "prospect theory" shows that the potential for a serious or irremediable loss will motivate decisionmakers to accept particularly high risks relative to the expected utilities of other choices. ${ }^{46}$

Indeed, the historical record shows that from time to time, states are willing to accept enormous gambles, even ones that endanger national survival, for important causes. Thucydides described the famous dialogue in 416 B.C. between the Athenian spokesmen and the besieged Melians, the latter choosing to risk (and eventually suffering) annihilation and colonization by refusing to end their neutrality in the Second Peloponnesian war. $^{47}$ Likewise, Keith Payne recounts several instances of states suffering total societal destruction in the wake of war, ranging from the sacking of Carthage at the conclusion of the Third Punic War to the devastation of Kiev by Mongol warriors in 1240. According to Payne, “...leaders in the past have known or believed that their decisions would affect the probability of utter societal destruction, at least for

International Security vol. 26, no. 1 (summer 2001): 67; Victor A. Utgoff, "Proliferation, Missile Defence and American Ambitions," Survival vol. 44, no. 2 (summer 2002): 91.

${ }^{43}$ Avery Goldstein, Deterrence and Security in the $21^{\text {st }}$ Century: China, Britain, France, and the Enduring Legacy of the Nuclear Revolution (Stanford, CA: Stanford University Press, 2000), 46 and 179.

44 Rhodes, Power and MADness, 51.

${ }_{45}$ Booth, Strategy and Ethnocentrism, 64 and 71.

${ }^{46}$ Watman and Wilkening, U.S. Regional Deterrence Strategies, 23.

47 Thucydides, The Peloponnesian War, translated by Rex Warner (London: Cassell \& Company Ltd., 1954), 358-366; Donald Kagan, On the Origins of War and the Preservation of Peace (New York:

Doubleday, 1995), 7-8. 
them and their society, but that prospect did not render threats thereof reliable instruments for deterrence or coercion. ${ }^{, 48}$

There are also numerous examples of weak states actually attacking the strong, believing that there were no other options open to them or that the resolve of their opponent was quite frail. T.V. Paul studied six asymmetric conflicts of the 20th Century, from the Russo-Japanese War to the Falklands Crisis, observing: "The stronger powers in all the cases anticipated that their own overall superiority in power capability would act as a general deterrent preventing their weaker opponents from engaging in war." Instead, factors beyond mere capability were at play, often with the weaker side hoping for a political victory or judging that the asymmetries of interest were sufficiently in their favor to make military success possible. ${ }^{50}$ The Yom Kippur War of 1973 between Israel and Egypt, for example, was one instance of a stronger state simply not being able to understand that dim military prospects do not always outweigh other factors such as honor, prestige, or even a political gambit for sympathy, in the decision for war. ${ }^{51}$ History is replete with accounts of states fighting against insurmountable odds in the name of intangible values such as dignity and freedom, including the American Confederacy, the Irish Easter Rising, and the Finns in $1940 .{ }^{52}$

In most regional conflicts, it is likely that local opponents would show considerable resolve given that any war would probably involve their core interests

\footnotetext{
${ }^{48}$ Keith B. Payne, Deterrence in the Second Nuclear Age (Lexington, KY: The University Press of Kentucky, 2001), 97.

${ }^{49}$ Paul, Asymmetric Conflicts, 62-164 and 170.

${ }^{50}$ Andrew Mack, "Why Big Nations Lose Small Wars: the Politics of Asymmetric Conflict," World Politics vol. XXVII, no. 2 (January 1975): 175-200; Barry Wolf, When the Weak Attack the Strong: Failures of Deterrence (Santa Monica, CA: RAND Note, 1991), 9-11; Brad Roberts, "From Nonproliferation to Antiproliferation," International Security vol. 18, no. 1 (summer 1993): 161.

${ }^{51}$ Martin van Creveld, Nuclear Proliferation and the Future of Conflict (New York: The Free Press, 1993), 101; Paul, Asymmetric Conflicts, 9. Operation Desert Storm provides another example; some analysts believe that Saddam Hussein held firm in the face of coalition air strikes because at times in Middle Eastern political cultures it is better to be defeated (though not destroyed) than dishonored. See Adam Garfinkle, "An Observation on Arab Culture and Deterrence: Metaphors and Misgivings," in Regional Security Regimes, edited by Efraim Inbar (Albany, NY: State University of New York Press, 1995), 205.

${ }^{52}$ Richard Ned Lebow and Janice Gross Stein, "Beyond Deterrence," Journal of Social Issues vol. 43, no. 4 (1987): 10.
} 
whereas the stakes for the United States might be more peripheral in nature. ${ }^{53}$ The best illustration of this confidence is once again a variation on the game of "chicken," with one driver as a convict on death row and the other a man with a family. ${ }^{54}$ In such a match of wills, there will be an inherent advantage in brinksmanship to the side that feels it has "nothing left to lose." Of course, to take the analogy one step further and incorporate capabilities, it is probably appropriate to depict the American "family man" as driving a large truck relative to the regional adversary. As Kenneth Waltz has remarked, referring to the military standoff on the Korean peninsula: "Our vast nuclear forces would not deter an attack on the South, yet the dinky force that the North may have would deter us!" 55 In the words of Colin Gray, however, "The huge disparity in physical strength between the United States and Iraq, Iran, or North Korea is all but beside the point when there is perceived to be no less huge disparity (to the disfavor of the United States) in intensity of national interest at stake." 56 This is especially true when WMD are involved, which can act as a strategic equalizer, a sort of "bomb on the bumper" that would damage even the American truck in the event of a collision.

It is certainly plausible to think of states that would care enough about a certain vital interest even to the point of risking national catastrophe. The oft-quoted Chinese general who told an American envoy: "In the end, you care more about Los Angeles than you do about Taipei," was demonstrating how asymmetries of interest strengthen their deterrent threat over a Taiwanese conflict. ${ }^{57}$ The Chinese leadership clearly places extremely high priority on restoring its lost province, and hardly anyone would doubt

\footnotetext{
${ }^{53}$ Thomas G. Mahnken, “America's Next War," The Washington Quarterly vol. 16, no. 3 (summer 1993): 175; Wilkening and Watman, Nuclear Deterrence in a Regional Context, ix.

${ }_{55}^{54}$ Wilkening and Watman, Nuclear Deterrence in a Regional Context, 12, footnote 14.

${ }^{55}$ Kenneth N. Waltz, "Peace, Stability, and Nuclear Weapons," in The Use of Force: Military Power and International Relations, edited by Robert J. Art and Kenneth N. Waltz, $5^{\text {th }}$ edition, (Maryland: Rowland \& Littlefield), 362.

${ }^{56}$ Colin S. Gray, The Second Nuclear Age (London: Lynne Rienner Publishers, Inc., 1999), 125-126.

${ }^{57}$ Quoted in Patrick E. Tyler, "As China Threatens Taiwan, It Makes Sure U.S. Listens," New York Times, 24 January 1996. See also James M. Lindsay and Michael E. O'Hanlon, Defending America: The Case for Limited National Missile Defense (Washington DC: Brookings Institution Press, 2001), 125.
} 
that it is at least possible that China would risk a nuclear exchange to prevent Taiwan's independence. John Arquilla surmises: "This asymmetry of relative motivation could prove the most serious external constraint on regional deterrence, for if an opponent is relatively impervious to threats that raise the specter of higher costs and risks for aggression, then the fundamental calculus of deterrence is overturned." ${ }^{, 58}$ In situations like these, it may be quite a gamble to assume that dominance in capabilities will compensate for an imbalance in interests and resolve.

The prospect of unpredictable leaders with unknown levels of risk-acceptance poses substantial problems for deterrence theory. Especially if states choose to hide their aggression until the last moment through a surprise attack, as Egypt did in the Yom Kippur War, there may not even be time for the defending state to issue an explicit deterrent threat. ${ }^{59}$ To be sure, there is little question that the risks involved in attacking the United States with WMD would be extraordinary, but such a decision cannot be ruled out, especially when there is an imbalance in interests and resolve. ${ }^{60}$ States in the past have accepted such supreme dangers, even on the level of putting their entire societies in mortal danger, and it would be remiss to assume that they never will do so again.

Commitment Tactics: As mentioned, while imposing audience costs in a brinksmanship contest can bolster resolve, if a leader's reputation becomes too invested in a particular stand, a "commitment trap" can develop that creates an obligation to follow through with a threat even into an undesired conflict. ${ }^{61}$ Expectations and $^{2}$ vulnerabilities can develop through imprudent posturing, making the fear of a domestic uprising due to a retreat the greater danger than forging ahead with a risky war. For

\footnotetext{
${ }^{58}$ John Arquilla, "Bound to Fail: Regional Deterrence after the Cold War," Comparative Strategy vol. 14, no. 2 (April-June 1995): 127.

${ }^{59}$ Morgan, Deterrence: A Conceptual Analysis, 40.

${ }^{60}$ Lewis A. Dunn, Controlling the Bomb: Nuclear Proliferation in the 1980s (New Haven, CT: Yale University Press, 1982), 83.

${ }^{61}$ Sagan, "The Commitment Trap," 86.
} 
example, in the build-up to the Sino-Indian war of 1962, Nehru is quoted as having told a colleague, "If I give them [a negotiated settlement], I shall no longer be Prime Minister of India."62 Beyond external constraints, internal psychological momentum can also bind decisionmakers to a commitment once it is made. ${ }^{63}$ Feelings of pride and defiance can coalesce into a rigid determination to stay the course regardless of cost. In the Ussuri River border conflict between the Soviet Union and China in 1969, both sides were determined not to be intimidated by nuclear blackmail and the subsequent military clashes were disturbingly close to escalating into full-scale war. ${ }^{64}$

Another commitment technique is to tie one's hands not through audience costs, but by the actual pre-delegation of command authority, known in the deterrence literature as setting up a "doomsday machine" or issuing a "threat that leaves something to chance." ${ }^{, 65}$ Essentially, the authority to carry out a deterrent threat is placed down the chain of command, usually out of a fear of the destruction of command/control links and the desire to shore up credibility by increasing the likelihood that there will be retaliation even should such an attack be successful. Shockingly, unknown to most observers, this strategy nearly led to the outbreak of war during the Cuban Missile Crisis. Recently released documents reveal that a Soviet submarine commander was on the verge of launching a nuclear-tipped torpedo in response to the American depth charges that were seeking to force him to the surface. Unaware of what was occurring on land, he is quoted as saying: "Maybe the war has already started up there, while we are doing somersaults here...We're going to blast them now! We will die, but we will sink them

\footnotetext{
${ }^{62}$ Quoted in Watman and Wilkening, U.S. Regional Deterrence Strategies, 44-45.

${ }^{63}$ Irving L. Janis and Leon Mann, Decision Making: A Psychological Analysis of Conflict (New York: The Free Press, 1977), 287.

${ }^{64}$ Alfred D. Law, The Sino-Soviet Dispute (London: Associated University Presses, 1976), 277; Richard Wich, Sino-Soviet Crisis Politics: A Study of Political Change and Communication (Cambridge, MA: Harvard University Press, 1980), 166; Harry Gelman, The Soviet Far East Buildup and Soviet Risk-Taking Against China (Santa Monica, CA: RAND, August 1982), 41; Lyle J. Goldstein, "Do Nascent WMD Arsenals Deter? The Sino-Soviet Crisis of 1969," Political Science Quarterly vol. 118, no. 1 (spring 2003): 53-79.

${ }^{65}$ Rhodes, Power and MADness, 155.
} 
all. We will not disgrace our navy!"66 Fortunately the commander relented after conferring with his other officers, though the incident should serve as a sobering reminder of the limited control over wartime situations and the dangers of predelegation. Commitment tactics can be very savvy, but also incredibly dangerous if one's opponent does the same or refuses to give in.

Psychological Effects and the Rationality of the Irrational: Recognizing that cool, calculated decisionmaking will tend to strengthen deterrence, states may deliberately or implicitly cultivate a reputation for "irrational" behavior that paradoxically may be a very rational image to project. ${ }^{67}$ Nikita Khruschev is one famous example of a leader who sought to come across as slightly unstable in order to gain leverage in brinksmanship contests. ${ }^{68}$ Beyond such partial deception, there are also many naturally occurring psychological biases and influences that could make a crisiswhich by its very nature is inherently unstable- "get out of hand" in the heat of the moment. ${ }^{69}$ The rationality of decisionmakers "may be degraded by factors of personal character or by such adverse circumstances as time pressure, fatigue, and anxiety."70 Leaders can become desperate and panic, especially if extremist military cliques or domestic movements threaten their hold on power. Military factions might also push policy beyond the bounds the national leadership has set, as in the scenario of a "crazy colonel" independently lashing out with WMD to secure a sense of personal glory for landing a devastating blow against the West. ${ }^{71}$ Scholars of the conflicts between the

\footnotetext{
${ }^{66}$ Quoted in David Gonzalez, "At Cuba Conference, Old Foes Exchange Notes on 1962 Missile Crisis," New York Times, 14 October 2002.

${ }^{67}$ Patrick M. Morgan, "Saving Face for the Sake of Deterrence," in Psychology and Deterrence, edited by Robert Jervis, Richard Ned Lebow, and Janice Gross Stein (Baltimore, MD: Johns Hopkins University Press, 1985), 128; Rhodes, Power and MADness, 45 and 123.

${ }^{68}$ Schelling, Arms and Influence, 37.

${ }^{69}$ Ibid., 97.

${ }^{70}$ Klaus Knorr, The Power of Nations: The Political Economy of International Relations (New York: Basic Books, Inc., 1975), 41.

${ }^{71}$ Stephen M. Meyer, "Small Nuclear Forces and U.S. Military Operations in the Theater," in Small Nuclear Forces and U.S. Security Policy, edited by Rodney M. Jones (Washington, D.C.: Center for
} 
United States and North Korea in the late 1960s (assassination attempt on South Korean President Park Chung Hee in January 1968, seizure of the USS Pueblo in the same month, and the April 1969 downing of a U.S. Navy EC-121) point out that Kim Il Sung was forced to purge his aggressive generals after their subversive policies brought the nation uncomfortably close to war with the United States. ${ }^{72}$ During the Cuban Missile Crisis, another case study in the potential for disaster caused by organizational dysfunction, not only were the Soviet submariners on edge, but the U.S. political leadership was placed under intense stress and constant pressure from some military hawks to pursue a more belligerent course. ${ }^{73}$ More recently, the clashes between India and Pakistan over Kashmir have led some analysts to fear that the tension and political stakes involved have made war possible despite the potential for nuclear escalation. ${ }^{74}$ In sum, crises are often marked by surprises, mistakes, and catastrophic errors, all of which may work against the proper functioning of deterrence.

Even if leaders are functionally rational, there are numerous psychological biases and influences that can increase the likelihood of misperception and "sub-rational" behavior. It is important to recognize that deterrence is at root a psychological concept whose success requires a particular state of mind on the part of the opponent. In some cases, due to psychological effects, the target of a deterrence policy may simply not understand, fully register, or believe a particular threat. They may be resorting to

Strategic and International Studies, 1984), 164; George Quester, "The Future of Nuclear Deterrence," Survival vol. 34, no. 1 (spring 1992): 78.

${ }_{72}$ Dae-sook Suh, Kim Il Sung (New York: Columbia University Press, 1988), 239; Joseph S. Bermudez Jr., "The Democratic People's Republic of Korea and Unconventional Weapons," in Planning the Unthinkable, edited by Peter R. Lavoy, Scott D. Sagan, and James J. Wirtz (Ithaca, NY: Cornell University Press, 2000), 186-187.

${ }^{73}$ Sagan, in The Spread of Nuclear Weapons, 52; James G. Blight and David A. Welch, "Risking 'the Destruction of Nations:' Lessons of the Cuban Missile Crisis for New and Aspiring States," Security Studies vol. 4, no. 4 (summer 1995): 824.

${ }^{74}$ Waheguru Pal Sing Sidhu, "India's Nuclear Use Doctrine," in Planning the Unthinkable, edited by Lavoy, Sagan, and Wirtz, 143; Rajiv Chandrasekaran, "For India, Deterrence May Not Prevent War," Washington Post, 17 January 2002. See also Devin T. Hagerty, "Nuclear Deterrence in South Asia: the 1990 Indo-Pakistani Crisis," International Security vol. 20, no. 3 (winter 1995-96): 95. 
"wishful thinking," or only seeing what they expect or would like to see. ${ }^{75}$ Closely related to this is the concept of "denial" or "defensive avoidance," which involves refusing to fully consider evidence that contradicts a decision that has already been made. ${ }^{76}$ This type of "mental blinder" is known as a "motivated bias" since it satisfies a psychological need for peace of mind. In essence, when confronted with too many conflicting stimuli, a state of "cognitive dissonance" can develop, resulting in the distortion of information toward what one wants to believe in order to simplify an imminent decision or to cope with difficult and dangerous choices. ${ }^{77}$ Through defensive avoidance, evidence to the contrary is explained away, and "the decision maker achieves a state of 'pseudocalm' at the expense of effective search and appraisal."78 For example, in the lead-up to the bombing of Pearl Harbor, Admiral Kimmel screened out various warning signs that were mixed in with other intelligence by rationalizing that the Japanese would not dare make a surprise attack. The term "pseudocalm" is appropriate because the perception of calm may actually be quite false; the Argentinian junta, for instance, was quite off target in their wishful thinking that Britain would allow their fait accompli in the Falklands to stand unchallenged. ${ }^{79}$

Based on his analyses of past deterrence failures, Richard Lebow observed: "When leaders felt themselves compelled to pursue brinksmanship challenges, they frequently rationalized the conditions for their success." ${ }^{80}$ Lebow analyzed the information bias in the decisions that led to World War I, concluding that Germany's

\footnotetext{
${ }^{75}$ Robert Jervis, Perception and Misperception in International Politics (Princeton, NJ: Princeton University Press, 1976), 361.

${ }^{76}$ Robert Jervis, "Deterrence and Perception," International Security vol. 7, no. 3 (winter 1982-83): 29.

${ }_{78}^{7}$ Jervis, Perception and Misperception in International Politics, 382.

${ }^{78}$ Janis and Mann, Decision Making, 124.

${ }^{79}$ Janice Gross Stein "Calculation, Miscalculation, and Conventional Deterrence I: The View from Cairo," in Psychology and Deterrence, edited by Jervis, Lebow, and Stein, 108.

${ }^{80}$ Richard Ned Lebow, Between Peace and War: The Nature of International Crisis (Baltimore, MD: Johns Hopkins University Press, 1981), 335.
} 
hope for British neutrality in the event of war was nearly delusional. ${ }^{81}$ Especially when several individuals are brought together to make a decision, a phenomenon known as "groupthink" can arise, often resulting in a concurrence-seeking tendency and the development of an illusion of invulnerability. Janis and Mann examined several examples of this psychological bias, including Chamberlain's inner circle in 1937-38, Truman in the lead-up to Korea, and Kennedy in the Bay of Pigs fiasco. ${ }^{82}$ Once a state is committed to a certain policy, cognitive closure can set in, along with the conclusion that there are no other options available and that the risks involved with the chosen course are minimal. $^{83}$ Thus, it is always possible that even if a deterrent threat is credible and carefully communicated, the other side may simply not be listening or could misconstrue it as a bluff.

Finally, there is always the prospect that the leadership actually is mentally unbalanced, incapacitated, or following a non-rational method of decision-making. The infirmities of old age have affected numerous major political figures; U.S. presidents Woodrow Wilson and Ronald Reagan are among those who required some assistance toward the end of their terms. ${ }^{84}$ Several leaders in the past have abused drugs, including Hitler's cocaine treatments, Mao's barbiturate addiction, and South Korean President Park Chung Hee's alcoholism. Recently declassified U.S. State Department documents reveal that senior U.S. officials considered Park dangerously unstable and prone to issuing "all sorts of orders when he begins drinking" that were fortunately ignored until he became sober. ${ }^{85}$ There are further reports that Saddam Hussein relied on the advice of

\footnotetext{
${ }^{81}$ Ibid., 129-143.

82 Janis and Mann, Decision Making, 129; Booth, Strategy and Ethnocentrism, 107.

${ }^{83}$ Robert Jervis, "Perceiving and Coping with Threat," in Psychology and Deterrence, edited by Jervis, Lebow, and Stein, 32; Frank C. Zagare and D. Marc Kilgour, Perfect Deterrence (Cambridge: Cambridge University Press, 2000), 44.

${ }^{84}$ Jerome D. Frank, Sanity and Survival: Psychological Aspects of War and Peace (London: The Cresset Press, 1967), 60.

${ }^{85}$ Keith B. Payne, The Fallacies of Cold War Deterrence and a New Direction (Lexington, KY: The University Press of Kentucky, 2001), 58-59.
} 
"soothsayers" to provide assistance in making his ill-fated military decisions during the 1990-91 Gulf War. ${ }^{86}$ While instances of such erratic and unpredictable leaders may be rare, they are certainly dangerous if and when they do arise. ${ }^{87}$ All in all, the potential for misperception and irrationality in crises, be it feigned, deliberate, or actual, poses a significant challenge to the proper functioning of deterrence.

Last Resort Attacks: A major weakness of traditional deterrence theory is that it has little to offer in situations where vital interests may actually be in conflict. Richard Betts explains: "The logic of deterrence is clearest when the issue is preventing unprovoked and unambiguous aggression...Deterrence is less reliable when both sides in a conflict see each other as the aggressor... Such situations are ripe for miscalculation." As the United States seems to be moving toward a strategic outlook wherein rogue state WMD possession alone is an unacceptable security threat, mutual recriminations and competing claims of acting in self-defense are likely. This development could be very dangerous, since if the United States poses a severe challenge to an opposing regime or its perceived interests, the adversary's leadership may place certain values such as honor and dignity above life and even national survival. Some of these states are likely to be led by an unwavering belief in a powerful ideology or religious commitment, and there could be a readiness to sacrifice a great deal in its name. ${ }^{89}$ Moreover, faced with a potentially humiliating outcome to a war with the United States and/or its allies, revenge may even become a primary motivating factor. A government in its death throes might attack nihilistically or become obsessed with a martyr complex, feeling that it might as well implement a sort of "Samson" strategy and attempt to bring down its enemies along

\footnotetext{
${ }^{86}$ Ibid., 44.

${ }^{87}$ Yehezkel Dror, Crazy States: A Counterconventional Strategic Problem (Lexington, MA: Heath Lexington Books, 1971), xiii.

${ }^{88}$ Richard K. Betts, "The New Threat of Mass Destruction," Foreign Affairs vol. 77, no. 1

(January/February 1998): 33.

${ }^{89}$ Dror, Crazy States, 7.
} 
with itself. ${ }^{90}$ In the words of former Secretary of Defense Perry, such regimes "may not buy into our deterrence theory. Indeed, they may be madder than MAD."91

The concept of "undeterrable" states with leaders willing to sacrifice everything has some historical precedent. Hitler, for instance, called for a scorched earth form of national self-destruction in his infamous Nero orders of 18 and 19 March $1945 .^{92}$ A few months later, even after the atomic bomb devastated Hiroshima, some military leaders in Japan were contemplating a suicidal last stand, with the war minister musing: "Would it not be wondrous for this whole nation to be destroyed like a beautiful flower?"93 Such examples defy arguments that deterrence will always be sufficient to hold nations back from carrying out their WMD threat due to the ruinous repercussions. ${ }^{94}$ It is fully possible that some leaders will be willing to "go down with their state" rather than accept the loss of power or experience military defeat. ${ }^{95}$ Even Winston Churchill, notwithstanding his considerable confidence in the nuclear "balance of terror," still allowed for the "formidable admission" that such a deterrent did not apply to "lunatics or dictators in the mood of Hitler when he found himself in his final dugout." 96 In these circumstances, a final revenge attack may actually be "rational" in the mind of a desperate leader despite its consequences.

Many analysts concur, arguing prior to Operation Iraqi Freedom that Saddam Hussein would sooner start a Third World War than give up office voluntarily and that

\footnotetext{
${ }^{90}$ Seymour M. Hersh, The Samson Option: Israel, America and the Bomb (London: Faber, 1991); Lewis A. Dunn, Containing Nuclear Proliferation, Adelphi Paper No. 263 (London: International Institute for Strategic Studies, winter 1991), 24 and 26; Barry R. Schneider, "Strategies for Coping with Enemy Weapons of Mass Destruction," Airpower Journal (Special Edition 1996): 42; Haselkorn, The Continuing Storm, 151; James M. Lindsay and Michael E. O'Hanlon, "Correspondence," International Security vol. 26, no. 4 (spring 2002): 192.

${ }^{91}$ Quoted in Stephen J. Cimbala, The Past and Future of Nuclear Deterrence (Westport, CT: Praeger Publishers, 1998), 107.

${ }^{92}$ Albert Speer, Inside the Third Reich (New York: Macmillan Company, 1970), 440; Joachim Fest, Speer: The Final Verdict (London: Phoenix Press, 1999), 250-251.

${ }^{93}$ Quoted in David McCullough, Truman (New York: Simon \& Schuster, 1992), 459.

94 Thomas L. Friedman, "Who's Crazy Here?" New York Times, 15 May 2001.

${ }^{95}$ Dunn, Containing Nuclear Proliferation, 24.

${ }^{96}$ Quoted in Fred Charles Iklé, "Can Nuclear Deterrence Last Out the Century?" Foreign Affairs vol. 51, no. 2 (January 1973): 269.
} 
North Korea would likely launch a WMD attack in the event that the United States tried to eliminate its nuclear facilities. ${ }^{97}$ Indeed, given the number of suicide bombers that are willing to sacrifice their lives in the Arab-Israeli conflict, is it really that hard to imagine that a given leader would not at some point volunteer his state to serve that role? Radovan Karadzic, leader of the Bosnian Serbs, implied as much, threatening: "We are not prepared to give up our own self-defense. It is no problem to buy nuclear weapons on the world market. We will really carry it through. We have nothing to lose."98 During the Cuban Missile Crisis, Che Guevara and Castro reportedly urged a preemptive strike on the United States, preferring to sacrifice Cuba and "die beautifully" in the fight against American imperialism. ${ }^{99}$ As with the submarine commander, fortunately the Soviet Vice-Premier Anastas Mikoyan was able to overrule them, taking a much more conservative view of the situation. ${ }^{100}$ As Keith Payne notes, however: "In future crises, leaders ready to 'die beautifully' may be in control of missiles, and their cost-benefit calculus will not permit the predictable functioning of deterrence." ${ }^{101}$ Overall, while it may be true that rogue leaders will rarely risk massive retaliation since they "want to have a country that they can continue to rule," this simple logic becomes upended if regime change or unconditional surrender is the objective, which in many rogue states may end up resulting in the leader's death. ${ }^{102}$

\footnotetext{
${ }^{97}$ Bermudez, "The DPRK and Unconventional Weapons," 197; James Dao, "Pentagon's Worry: Iraqi Chemical Arms," New York Times, 19 May 2002; Bradley Graham, "'Scorched Earth' Plans in Iraq Cited," Washington Post, 19 December 2002; Michael R. Gordon, "Iraq Said to Plan Strategy of Delay and Urban Battle," New York Times, 16 February 2003; Rowan Scarborough, "Saddam Ready to Kill Iraqis, Blame U.S.," Washington Times, 12 March 2003.

${ }^{98}$ Quoted in Philip L. Ritcheson, "Proliferation and the Challenge to Deterrence," Strategic Review vol. XXIII, no. 2 (spring 1995): 42 (italics his).

${ }^{99}$ Quoted in Blight and Welch, "Risking 'the Destruction of Nations," 842. See also Payne, The Fallacies of Cold War Deterrence, 50.

${ }^{100}$ Robert T. Kadish, Speech at the Military Appreciation Banquet, Fairbanks, Alaska, 2 March 2001.

${ }^{101}$ Payne, The Fallacies of Cold War Deterrence, 52.

${ }^{102}$ Waltz, in The Spread of Nuclear Weapons, 13; Wilkening and Watman, Nuclear Deterrence in a Regional Context, 36.
} 
Millenarian Regimes: More troubling still is the potential that certain regimes will want to carry out WMD attacks regardless of whether their vital interests are threatened. Brad Roberts opines: "Proliferation may put strategic weapons in the hands of messianic leaders seeking to wage wars of ethnic or religious righteousness against what they perceive to be a corrupt, secular world...."103 Millenarian states and religious fanatics might seek destruction for its own sake, lashing out against America and its allies in retribution or to serve some higher end. Ramzi Yousef, the mastermind behind the 1993 World Trade Center bombing, claimed that he was retaliating for U.S. aid to Israel and hoped to kill 250,000 Americans. ${ }^{104}$ Such states and groups may even welcome the consequences of devastating American reprisals, justifying them as an act of martyrdom in service of a deity or ideology. ${ }^{105}$ A strong belief in an afterlife could create an extreme determination and willingness to sacrifice, brought about by the promise of great rewards after death. ${ }^{106}$ As with incapacitated leaders, while individuals, groups, or states with such a frame of mind are probably rather rare, even a low level of incidence is a major cause for concern given the potential effects of WMD. After all, it took just over a dozen hijackers to bring down the Twin Towers, and there are similar networks of terror across the world. It is difficult to see how such covert organizations can be reliably deterred. In the words of U.S. Undersecretary of State John Bolton, the type of individuals who would crash airplanes into buildings are "not going to be

\footnotetext{
${ }^{103}$ Roberts, "From Proliferation to Antiproliferation," 161.

${ }^{104}$ Jessica Stern, "Terrorist Motivations and Unconventional Weapons," in Planning the Unthinkable, edited by Lavoy, Sagan, and Wirtz, 215-16.

${ }^{105}$ William E. Burrows and Robert Windrem, Critical Mass: The Dangerous Race for Superweapons in a Fragmenting World (London: Simon \& Schuster Ltd., 1994), 19; Martel, "Deterrence and Alternative Images of Nuclear Possession," 221.

${ }^{106}$ Richard A. Falkenrath, Robert D. Newman, and Bradley A. Thayer, America's Achilles' Heel: Nuclear, Biological, and Chemical Terrorism and Covert Attack (Cambridge, MA: MIT Press, 1998); Kristensen, Nuclear Futures, 19; Payne, The Fallacies of Cold War Deterrence, 49.
} 
deterred by anything."107 Such a realization has profound implications for the durability of deterrence in regional conflicts.

In the final analysis, there is no magic formula to ensure deterrence; in every instance the ultimate decision rests with the state being deterred. There are a variety of psychological, cultural, and political variables that can affect an adversary's reaction to a deterrent threat, and their response can never be guaranteed by any amount of military capability. ${ }^{108}$ Keith Payne explains:

The tremendous lethality of nuclear weapons may usefully focus leadership attention on occasion. Even very lethal threats, however, cannot bring to an end the enormous capacity of leaders to have poor judgment, impaired rationality, to pursue 'unreasonable' goals and embrace unreasonable values, to be ignorant, passionate, foolish, arrogant, or selectively attentive to risks and costs, and to base their actions on severely distorted perceptions of reality. ${ }^{109}$

Any number of factors can create a deterrence deficiency: a state misperceiving the threat involved; purposefully manipulating the risk of war; or even actually desiring war. A regime may be "rational," yet act in ways that an opposing state finds quite unreasonable or even senseless.

In general, in light of the magnitude of U.S. power, deterrence should work quite well, especially in cases of overt aggression against vital American interests, such as territorial defense of allies and the homeland. It is worth remembering, however, that deterrence has failed many times in the past, and even nuclear powers have come quite close to war despite the harrowing potential for escalation. In the case of actually resorting to WMD use, the exception would certainly prove the rule, upending any

\footnotetext{
${ }^{107}$ William J. Broad, Stephen Engelberg, and James Glanz, "Assessing Risks, Chemical, Biological, Even Nuclear," New York Times, 1 November 2001.

${ }^{108}$ Gordon A. Craig and Alexander L. George, Force and Statecraft: Diplomatic Problems of Our Time, $3^{\text {rd }}$ Edition (Oxford: Oxford University Press, 1995), 208; Garfinkle, "An Observation on Arab Culture and Deterrence," 205.

${ }^{109}$ Payne, The Fallacies of Cold War Deterrence, 75.
} 
confidence in a stable order based on deterrence. ${ }^{110}$ Overall, the burden of proof is clearly on the side that holds that such an attack could never occur. As AJP Taylor noted: "A deterrent may work ninety-nine times out of a hundred. On the hundredth occasion it produces catastrophe."111 Chapter Three will investigate the contemporary evidence of the likelihood of such a breakdown in deterrence.

${ }^{110}$ Richard K. Betts, "Universal Deterrence of Conceptual Collapse? Liberal Pessimism and Utopian Realism," in The Coming Crisis: Nuclear Proliferation, U.S. Interests, and World Order, edited by Victor A. Utgoff (Cambridge, MA: MIT Press, 2000), 52.

${ }^{111}$ Quoted in Payne, Deterrence in the Second Nuclear Age, xi. 


\section{Chapter 3}

\section{Deterrence with WMD: Crisis and Conflict with Iraq and North Korea}

We have seen that history is full of surprises; states attack unexpectedly, make rash decisions, and take astounding risks even in the face of military disaster. Such examples reveal the theoretical wrinkles in the assumption of rationality, and thereby raise considerable doubt over the reliability of deterrence itself. It remains to be seen, though, whether adding WMD to the equation will make deterrence a more reliable prospect. In the past, nearly without exception, states have only employed WMD when their opponents lacked a comparable capability, implying that restraint—or deterrence in some sense-would be likely if the potential to cause major destruction was mutual. ${ }^{1}$ This has certainly been the case among the world's nuclear powers despite a few harrowing close calls.

How well, then, do deterrent threats hold up in asymmetric regional conflicts or crises when both sides possess WMD? While very few cases with such conditions exist, this chapter will investigate two in particular: the 1990-91 Gulf War and the 1993-94 U.S.-North Korea crisis. Both examples involved implicit and explicit WMD threats, as well as efforts by participants to employ brinksmanship tactics in the hopes of gaining an advantage over their opponent. Fortunately neither instance resulted in WMD use, notwithstanding multiple failures of deterrence and compellence. I will examine the likely causes of such failures, as well as the equally relevant examples of deterrence success. I conclude that in each case regional actors sought to prevent U.S. interference by posing the prospect of WMD retaliation, and were never pushed to the extreme of having to make good on their threat. U.S. freedom of action was constrained by these

\footnotetext{
${ }^{1}$ Kathleen Bailey, Doomsday Weapons in the Hands of Many: The Arms Control Challenge of the 90s (Chicago: University of Illinois Press, 1991), 63.
} 
threats, particularly in North Korea, and American counter-threats frequently went unheeded, notably in Iraq. Neither example supports the notion that deterrence is stable or reliable in regional conflicts.

\section{U.S.-Iraq and the Gulf War (1990-91)}

The strategic interaction between the United States and Iraq has always been complex. In the aftermath of World War II, monarchical Iraq for a time was a promising bulwark of stability in the Middle East, forming the core of the Baghdad Pact, a NATOsponsored military alliance intended to quell communist and liberation movements in the region. The Iraqi revolution in 1958 came as quite a shock to the West, terminating Iraq's participation in the Baghdad Pact and ushering in years of turmoil. The subsequent violence was capped by a Ba'athist coup in 1968 that paved the way for Saddam Hussein's eventual accession to the presidency in 1979 , the same year as the revolution in Iran. Given the West's extreme antipathy toward Ayatollah Khomeini, the United States was eager to assist Hussein in his quest for military power, especially once war broke out between Iran and Iraq a year later. ${ }^{2}$

Despite the imperative to assist a de facto ally, the United States was never quite at ease with the rapid advancement of Iraq's WMD capabilities during this period, a tension that resulted in considerable controversy given the subsequent deterioration in relations. ${ }^{3}$ The extensive use of chemical weapons $(\mathrm{CW})$ during the war with Iran only exacerbated these misgivings, as Iraq experimented with a whole range of toxins and

\footnotetext{
${ }^{2}$ For a full account of this support, see Kenneth R. Timmerman, The Death Lobby: How the West Armed Iraq (London: Fourth Estate Limited, 1992) and Leonard A. Cole, The Eleventh Plague: The Politics of Biological and Chemical Warfare (New York: W.H. Freeman and Company, 1997), 81.

${ }^{3}$ Barry Rubin, "The United States and Iraq: From Appeasement to War," in Iraq's Road to War, edited by Amatzia Baram and Barry Rubin (London: Macmillan Press, 1994), 257; Patrick E. Tyler, "Officers Say U.S. Aided Iraq in War Despite Use of Gas," New York Times, 18 August 2002.
} 
nerve gases. ${ }^{4}$ The conflict turned especially brutal toward the end, when Iraq fired more than 160 Scud missiles toward Tehran alone during the infamous "War of the Cities" in early $1988 .^{5}$ Hussein also stepped up the CW attacks, the most egregious of which occurred at Halabja in March of 1988, when a mixture of mustard gas and the nerve agents sarin, tabun, and VX killed over 5,000 Iraqi civilians, most of them Kurds. ${ }^{6}$

The Iraqi willingness to employ unconventional weapons became a yet greater worry once the remnants of the alliance with the United States fell apart and Iraq began to make preparations for the annexation of Kuwait. Hussein minced no words in attempting to capitalize on this fear, warning in May of 1990 that any military aggression against him would be met by a counterattack to "sweep away U.S. influence in the region."7 Around the same time he made a similar threat to Israel, alluding to his CW arsenal: "I swear to God that we shall burn half of Israel if it tries to wage anything against Iraq."8 In a meeting with the American ambassador just prior to invading Kuwait, Hussein broadened his threat to include terrorist reprisals against the United States, stating: "We cannot come all the way to you in the United States, but individual Arabs may reach you." $" 9$ Tariq Aziz, then Iraqi foreign minister, soon extended this admonition to all of America's allies, contending that Iraq would be "free of any moral constraint" if attacked. ${ }^{10}$

\footnotetext{
${ }^{4}$ David B. Ottaway, "In Mideast, Warfare With a New Nature," Washington Post, 5 April 1988; Dilip Hiro, The Longest War: The Iran-Iraq Military Conflict (New York: Routledge, 1991), 209.

${ }^{5}$ Thomas L. McNaugher, "Ballistic Missiles and Chemical Weapons: The Legacy of the Iran-Iraq War," International Security vol. 15, no. 2 (fall 1990): 5.

${ }^{6}$ Youssef M. Ibrahim, "Iran Reports New Iraqi Gas Raids, And Says Cities May be Hit Next," New York Times, 2 April 1988; Patrick E. Tyler, "Both Iraq and Iran Gassed Kurds in War, U.S. Analysis Finds," Washington Post, 3 May 1990; Adel Darwish and Gregory Alexander, Unholy Babylon: The Secret History of Saddam's War (London: Victor Gollancz Ltd., 1991), 78; Christine Gosden, "Why I Went, What I Saw," Washington Post, 11 March 1998.

${ }^{7}$ Quoted in Amatzia Baram, "The Iraqi Invasion of Kuwait: Decision-Making in Baghdad," in Iraq's Road to War, edited by Baram and Rubin, 11.

${ }^{8}$ Ibid.

${ }^{9}$ Quoted in Dilip Hiro, Desert Shield to Desert Storm: The Second Gulf War (New York: Routledge, 1992), 92.

${ }^{10}$ Quoted in Efraim Karsh and Inari Rautsi, Saddam Hussein: A Political Biography (London: Brassey's, 1991), 232.
} 
After occupying Kuwait, as tensions mounted toward war, Hussein also tried to raise the prospect of mass casualties, promising “...whoever attacks Iraq will find in front of him columns of dead bodies which may have a beginning but may not have an end." 11 According to some reports, Iraq openly and ostentatiously loaded and then removed chemical weapons from aircraft in an attempt to deter U.S. military action. ${ }^{12}$ Once the coalition air strikes began, Hussein became even more explicit regarding the potential for WMD use, commenting in an interview with a CNN reporter: "I pray to God I will not be forced to use these [nonconventional] weapons, but I will not hesitate to do so should the need arise."13 Al-Qadisiya, a prominent Iraqi newspaper, intoned a few days later: "We will use whatever power and weapons are at our disposal, starting from kitchen knives to weapons of mass destruction."14 Even the Iraqi Ambassador to the UN, Abd al-Amir al-Anbari, warned: "If the high-altitude bombings against Iraq are not stopped, we would have no choice but to resort to weapons of mass destruction."15 Most dramatically of all, just before the Coalition ground campaign Hussein insinuated the possibility of imminent CW use by asking "the people of justice" to "forgive Iraq for any action they will initiate." 16 In essence, Hussein attempted to initially deter the United States and the coalition forces from intervening at all, and then from taking the war too far by threatening to launch $\mathrm{CW}$ attacks against allied troops, Israel, and Saudi Arabia.

\footnotetext{
${ }^{11}$ Quoted in Avigdor Haselkorn, The Continuing Storm: Iraq, Poisonous Weapons, and Deterrence (New Haven, CT: Yale University Press, 1999), 35.

${ }^{12}$ R. Jeffrey Smith, "U.S. Warns of Retaliation if Iraq Uses Poison Gas," Washington Post, 9 August 1990; Karsh and Rautsi, Saddam Hussein: A Political Biography, 232.

${ }^{13}$ Quoted in Con Coughlin, Saddam: The Secret Life (London: Macmillan, 2002), 268.

${ }^{14}$ John Swain and James Adams, "Saddam Gives Local Commanders Go-Ahead for Chemical Attacks," Sunday Times, 3 February 1991.

${ }^{15}$ Quoted in Karsh and Rautsi, Saddam Hussein: A Political Biography, 260.

${ }^{16}$ Quoted in Timothy V. McCarthy and Jonathan B. Tucker, "Saddam's Toxic Arsenal: Chemical and Biological Weapons in the Gulf Wars," in Planning the Unthinkable: How New Powers Will Use Nuclear, Biological, and Chemical Weapons, edited by Peter R. Lavoy, Scott D. Sagan, and James J. Wirtz, (Ithaca, NY: Cornell University Press, 2000), 68.
} 
The United States, for its part, was certainly not a silent recipient of such dire warnings. President Bush wrote a letter to Saddam Hussein that was delivered to Tariq Aziz, stating that if chemical or biological weapons were used, "The American people would demand the strongest possible response. You and your country will pay a terrible price if you order such unconscionable action of this sort."17 The envoy to that meeting,

Secretary of State James Baker, made the most explicit counter-threat in person:

If the conflict starts, God forbid, and chemical or biological weapons are used against our forces, the American people would demand revenge, and we have the means to implement this. This is not a threat, but a pledge that if there is any use of such weapons, our objective would not be only the liberation of Kuwait, but also the toppling of the present regime. Any person who is responsible for the use of these weapons would be held accountable in the future...we will not permit terrorism to be directed against Americans or against their partners in this coalition, and we will not allow any attempt to destroy Kuwaiti oilfields. ${ }^{18}$

After hostilities began in January, Defense Secretary Cheney reiterated the point, stressing that "were Saddam Hussein foolish enough to use weapons of mass destruction, the U.S. response would be absolutely overwhelming and devastating."19

Since there is no concrete evidence that Iraq resorted to WMD during the Gulf War, most analysts draw the conclusion that U.S. threats to that effect were successful. ${ }^{20}$ Indeed, if post-war accounts from the Iraqi leadership and military command are accurate, there is little doubt that they believed the coalition (as well as Israel) was

\footnotetext{
${ }^{17}$ George Bush and Brent Scowcroft, A World Transformed (New York: Alfred A. Knopf, 1998), 442.

${ }^{18}$ Lawrence Freedman and Efraim Karsh, The Gulf Conflict 1990-1991: Diplomacy and War in the New World Order (London: Faber and Faber, 1993), 257.

${ }^{19}$ Quoted in Robert Toth, "American Support Grows for Use of Nuclear Arms," Los Angeles Times, 3 February 1991.

${ }^{20}$ Kenneth N. Waltz, "More May be Better," in Scott D. Sagan and Kenneth N. Waltz, The Spread of Nuclear Weapons: A Debate (New York: W.W. Norton \& Company, 1995), 13; Robin Ranger and David Wiencek, The Devil's Brews II: Weapons of Mass Destruction and International Security (Lancaster: Centre for Defence and International Security Studies, Bailrigg Memorandum 17, 1997), 21; Daniel Byman, Kenneth Pollack, and Matthew Waxman, "Coercing Saddam Hussein: Lessons from the Past," Survival vol. 40, no. 3 (autumn 1998): 132; Robert G. Joseph and John F. Reichart, Deterrence and Defense in a Nuclear, Biological, and Chemical Environment (Washington D.C.: National Defense University Press, 1999), 19; Robert S. Litwak, Rogue States and U.S. Foreign Policy: Containment after the Cold War (Baltimore, MD: Johns Hopkins University Press, 2000), 41; Jan Lodal, The Price of Dominance: The New Weapons of Mass Destruction and Their Challenge to American Leadership (New York: Council of Foreign Relations, 2001), 25.
} 
prepared to use nuclear weapons or topple Hussein had Iraq attacked with CW. ${ }^{21}$ This assessment, however, is usually unqualified, and presented without much direct evidence to substantiate such a significant finding. Sometimes the "proof" is as spurious as claiming that since copies of Bush's letter were found all around Iraq after the war, the threats therein must have been effective. ${ }^{22}$ Very few commentators ask the decisive question of whether deterrence would have continued to hold firm if coalition forces had begun to directly threaten Hussein's grip on power with an attack on Baghdad itself. While just such a military operation has taken place over ten years later, considerable uncertainty and disagreement remains even now over why Iraq did not turn to WMD-if it had them-as a last resort option. ${ }^{23}$ Moreover, even if we judge deterrence to be a success in the present day, or that there was nothing to deter, it would not prove that similar restraint would have prevailed under quite different circumstances in 1991.

Counterfactuals like this, of course, have no easy answers. One critical indicator of Hussein's intentions is the nature of his WMD capabilities and deployments at the time, for such preparations would hardly be made without any intent for their use in combat or as a tool of deterrence. Much of our knowledge of these aspects comes from either UN weapons inspections or information from the defection in August 1995 of Hussein's son-in-law, Hussein Kamil Hassan al-Majid, who was in charge of Iraq's biological weapons (BW) program after its launch in 1985. We now know, for instance, that Iraq deployed 191 weapons (both aerial bombs and missiles) carrying BW to two

\footnotetext{
${ }^{21}$ William M. Arkin, "Calculated Ambiguity: Nuclear Weapons and the Gulf War," The Washington Quarterly vol. 19, no. 4 (autumn 1996): 9; Robert W. Chandler with Robert J. Trees, Tomorrow's War, Today's Decisions: Iraqi Weapons of Mass Destruction and the Implications of WMD-Armed Adversaries for Future U.S. Military Strategy (McLean, VA: AMCODA Press, 1996), 64; Cole, The Eleventh Plague, 128.

${ }^{22}$ Walter Pincus, "Military Study Mulled Deterrence of 'Fear," Washington Post, 5 July 2001.

${ }^{23}$ Tony Capaccio, "U.S. Tactics May Have Blunted Iraqi Chemical Threat," Bloomberg.com, 8 April 2003; Brian Knowlton, "War Largely Going as Planned, Pentagon Says," New York Times, 9 April 2003; Therese Delpech, "The Weapons Hunt," Wall Street Journal, 16 April 2003; Bryan Bender, "Regime Ordered Chemical Attack, Investigator Says," Boston Globe, 8 August 2003; Walter Pincus and Dana Priest, "Hussein's Weapons May Have Been Bluff," Washington Post, 1 October 2003; Douglas Jehl, "Iraq Removed Arms Material, Aide Says," New York Times, 29 October 2003.
} 
sites before the Gulf War. ${ }^{24}$ At least three separate BW agents were weaponized for use during war-developed to serve both tactical and strategic missions. ${ }^{25}$ Moreover, as late as December 1990, Iraq was working on a spray tank to deliver anthrax by remotely piloted plane and had conducted field trials of munitions containing anthrax simulant and botulinum toxin. ${ }^{26}$ According to Rolf Ekeus, then chief UN arms inspector, BW were "Baghdad's last trump card and could have been fired immediately-which is really unique. Bombs with biologically effective material were already stationed at military air bases and rocket launching sites. This is an absolute novelty-worldwide."27

As for CW preparation, there is evidence that Iraq had thirty CW Scud warheads ready for launch and even established chemical decontamination sites for protection. ${ }^{28}$ UN inspections confirmed that Iraq deployed gas-filled $155 \mathrm{~mm}$ artillery and $122 \mathrm{~mm}$ multiple rocket rounds into the rear areas of the war theatre. Shockingly, Iraq's chemical weapons had no special visible markings, and were often stored in the same area as conventional weapons. $^{29}$ Overall, given the unlikely U.S. initiation of WMD use, the extensive weaponization and deployment of Iraq's chemical-biological (CB) capability casts doubt on claims that such weapons were solely a deterrent against U.S. nuclear strikes and would never be used first under any circumstances, as they were designed much more for war fighting then revenge attacks.

One crucial point of contention is whether or not Saddam Hussein actually predelegated control over any $\mathrm{CB}$ weapons to lower-level commanders, a "commitment

\footnotetext{
${ }^{24}$ Raymond A. Zilinskas, "Iraq's Biological Warfare Program: The Past as Future?" in Biological Weapons: Limiting the Threat, edited by Joshua Lederberg (Cambridge, MA: The MIT Press, 1999), 141; Haselkorn, The Continuing Storm, 13; McCarthy and Tucker, "Saddam's Toxic Arsenal," 54.

${ }^{25}$ Anthony H. Cordesman, Iran's Military Forces in Transition: Conventional Threats and Weapons of Mass Destruction (Westport, CT: Praeger Publishers, 1999), 254.

${ }^{26}$ Chandler, Tomorrow's War, Today's Decisions, 78; McCarthy and Tucker, "Saddam's Toxic Arsenal," 53. However, the remotely piloted plane was probably not operational, and would have been quite vulnerable given U.S. air superiority. See Zilinskas, "Iraq's Biological Warfare Program: The Past as Future?" 146.

${ }^{27}$ Quoted in Haselkorn, The Continuing Storm, 1-2.

${ }^{28}$ Ibid., 26 and 37.

${ }^{29}$ Cordesman, Iran's Military Forces in Transition, 251.
} 
tactic" normally used to enhance credibility. Some analysts argue that CB authority was quite circumscribed and probably released on a very strict basis, if at all. ${ }^{30}$ However, the growing consensus on this issue is that Hussein did authorize local commanders to launch $\mathrm{CW}$ in the event of his death or the destruction of command and control links. ${ }^{31}$ Recent scholarship reveals that Hussein probably hedged his bets against the dangers of unauthorized WMD use on the one hand, and the risk of a decapitation blow against him on the other, granting authority to a special unit commander to carry out a revenge attack in the event of a coalition nuclear strike. ${ }^{32}$

While uncertainty remains over whether Iraq would have actually escalated to WMD if Hussein's hold on power was jeopardized, the reported contingency plans lead to the conclusion that it was certainly possible if not probable. This assessment is supported by British, U.S., and Israeli intelligence reports at the time that viewed CB attacks as likely in any event, and all but assured if Iraq was defeated and Hussein felt he was on the brink of being ousted. ${ }^{33}$ Most telling, Central Command's Situation Report

\footnotetext{
${ }^{30}$ Lawrence Freedman and Efraim Karsh, "How Kuwait Was Won: Strategy in the Gulf War," International Security vol. 16, no. 2 (fall 1991): 34; Ranger and Wiencek, The Devil's Brews II, 43.

${ }^{31}$ Lewis A. Dunn, Containing Nuclear Proliferation, Adelphi Paper No. 263 (London: International Institute for Strategic Studies, winter 1991), 21; Elaine Sciolino, The Outlaw State: Saddam Hussein's Quest for Power and the Gulf Crisis (New York: John Wiley \& Sons, Inc., 1991), 258; Hiro, Desert Shield to Desert Storm, 337; Chandler, Tomorrow's War, Today's Decisions, 90; Paul Bracken, Fire in the East: The Rise of Asian Military Power and the Second Nuclear Age (New York: Harper Collins Publishers, 1999), 40; Haselkorn, The Continuing Storm, 49; Scott D. Sagan, "The Commitment Trap: Why the United States Should Not Use Nuclear Threats to Deter Biological and Chemical Weapons Attacks," International Security vol. 24, no. 4 (spring 2000): 109; Joseph Cirincione, with John B. Wolfsthal and Miriam Rajkumar, Deadly Arsenals: Tracking Weapons of Mass Destruction (Washington D.C.: Carnegie Endowment for International Peace, June 2002), 279; Bob Drogin, “'91 Iraq Toxics Plan Reported," Los Angeles Times, 10 March 2003.

${ }^{32}$ McCarthy and Tucker, "Saddam's Toxic Arsenal," 76; Kenneth Pollack, "Why Iraq Can't Be Deterred," New York Times, 26 September 2002. To be fair, Iraqi officials stress the second-strike nature of this capability; Hussein himself is even reported as stating that Iraq "knew its limits" and well understood the mismatch between Israel's nuclear capability and his own country's chemical one. See Martin van Creveld, Nuclear Proliferation and the Future of Conflict (New York: The Free Press, 1993), 117.

${ }^{33}$ Swain and Adams, "Saddam Gives Local Commanders Go-Ahead for Chemical Attacks"; Lisa Beyer, "Coping with Chemicals," Time, 25 February 1991; Tom Masland with Douglas Waller, "Are We Ready for Chemical War?" Newsweek, 4 March 1991; Michael R. Gordon and General Bernard E. Trainor, The General's War (New York: Little, Brown and Company, 1995), 355; Haselkorn, The Continuing Storm, 59; Judith Miller, Stephen Engleberg, and William Broad, Germs: The Ultimate Weapon (London: Simon \& Schuster UK Ltd., 2001), 113; Richard L. Russell, "CIA's Strategic Intelligence in Iraq," Political Science Quarterly vol. 117, no. 2 (summer 2002): 200.
} 
on 24 February, the eve of the ground war, stated that it expected Iraq to initiate chemical operations within twenty-four hours. ${ }^{34}$ Even the Soviet Union was fearful of a chemical response to the initiation of a ground war. ${ }^{35}$ As Iraqi scholar Amatzia Baram put it: "The logic behind [Hussein's pre-delegation] is that he preferred Baghdad be annihilated rather than conquered by the Allied forces." "36 Iraq clearly began "rocking the boat" with its missile attacks on Israel, and sent an especially potent signal when it launched a missile toward the Israeli nuclear facility at Dimona. This was quite a dangerous decision, especially since Israel was barely restrained from striking back. ${ }^{37}$ As Scott Sagan remarked: "How could Saddam Hussein have been absolutely certain that Israel would not retaliate with nuclear weapons? Governments take gambles, especially when they are in desperate straits." 38 Notably, this missile-a Scud variant known as "al Hijarah" - was full of hardened concrete, an indication that it was capable of containing BW. ${ }^{39}$ Avigdor Haselkorn concludes that this missile was not a mistake, but the indirect delivery of a last-resort threat. According to Haselkorn, "Saddam was apparently hoping to convince his enemies that if they were thinking about toppling him, he was ready to bring Israel and perhaps the entire Middle East with him." ${ }^{40}$ In sum, it is not completely clear that Hussein was ever actually deterred; it is possible that "the fighting ended before the U.S. (or, for that matter, Israeli) deterrence could be put to the test." ${ }^{, 41}$ Indeed,

\footnotetext{
${ }^{34}$ William M. Arkin, "Calculated Ambiguity: Nuclear Weapons and the Gulf War," The Washington Quarterly vol. 19, no. 4 (autumn 1996): 7.

${ }_{35}^{35}$ Dilip Hiro, Desert Shield to Desert Storm: The Second Gulf War (New York: Routledge, 1992), 349.

${ }^{36}$ Amatzia Baram, "Saddam Husayn: Between His Power Base and the International Community," Middle East Review of International Affairs vol. 4, no. 4 (December 2000): 19.

${ }^{37}$ Rick Atkinson, Crusade: The Untold Story of the Gulf War (London: Harper Collins Publishers, 1994), 84.

${ }^{38}$ Sagan, in The Spread of Nuclear Weapons, 129 (italics his).

${ }^{39}$ Ofra Bengio, Saddam's World: Political Discourse in Iraq (New York: Oxford University Press, 1998), 201. See also http://www.fas.org/nuke/guide/iraq/missile/al_hussein.htm.

${ }^{40}$ Haselkorn, The Continuing Storm, 72-75. Based on interviews with U.S. government officials, if this was Hussein's intent, the message was not adequately communicated and the al Hijarah missile did not affect coalition war operations. Buster Glosson, phone interview with author, 26 August 2003; Brent Scowcroft, phone interview with author, 28 August 2003; James Baker, phone interview with author, 20 November 2003.

${ }^{41}$ Haselkorn, The Continuing Storm, 85.
} 
if the Gulf War was definitive proof of the futility of threatening the use of CB weapons, one must explain the various reports of Iraqi warnings-though admittedly now it appears that they were backed up with questionable capabilities—of a "red-line" around Baghdad that was to serve as a trip-wire for $\mathrm{CW}$ use during Operation Iraqi Freedom. ${ }^{42}$

When looked at in this way, the question is not simply whether Iraq was deterred from using WMD, but indeed whether the United States itself was deterred from achieving all of its objectives in Operation Desert Storm. While it is true that the United States never explicitly identified ousting Hussein as its war aim, there is ample evidence that this was highly desired; President Bush called upon the Iraqi people to "take matters into their own hands, to force Saddam Hussein, the dictator, to step aside," and even remarked that the American people did not want to "let Saddam get away." nearly all U.S. analysts reassuring Bush that Hussein would surely fall on his own, though, there was little reason to continue fighting even if much of the Iraqi army was in full retreat. ${ }^{44}$ Moreover, there would have been other major obstacles in taking the war to Baghdad. U.S. policymakers noted the risk of transforming Hussein into a nationalist hero, the costs of occupation when dealing with a hostile population, and the danger of opening the region up to Iranian influence through the "Lebanonization of Iraq."

\footnotetext{
${ }^{42}$ Bradley Graham, "'Scorched Earth' Plans in Iraq Cited," Washington Post, 19 December 2002; Philip Sherwell and David Wastell, "Iraq Has Poison Bombs," London Sunday Telegraph, 23 February 2003; Greg Jaffe, "Intelligence Suggests Hussein Allowed Chemical-Weapon Use," Wall Street Journal, 20 March 2003; David E. Sanger, "U.S. Officials Fear Iraqis Plan to Use Gas on G.I.'s," New York Times, 25 March 2003; Bernard Weinraub, "Army Reports Iraq is Moving Toxic Arms to its Troops," New York Times, 28 March 2003; Bill Gertz, "Coalition Still Wary of Chemical Weapons," Washington Times, 5 April 2003.

${ }^{43}$ Bush and Scowcroft, $A$ World Transformed, 483; Atkinson, Crusade, 303. See also James A. Baker III, with Thomas M. DeFrank, The Politics of Diplomacy (New York: G.P. Putnam's Sons, 1995), 408 and Secretary of State Baker's comment that there is "unfinished business" in Gordon and Trainor, The General's War, 416.

${ }^{44}$ Michael Sterner, "Closing the Gate: The Persian Gulf War Revisited," Current History vol. 96, no. 606 (January 1997): 14; Andrew Cockburn and Patrick Cockburn, Out of the Ashes: The Resurrection of Saddam Hussein (London: Verso, 2000), 37.

${ }^{45}$ Patrick E. Tyler, "Stirring the Iraqi Pot," New York Times, 21 March 1991; Yuen Foong Khong, "Vietnam, the Gulf, and U.S. Choices: A Comparison," Security Studies vol. 2, no. 1 (autumn 1992): 89; Atkinson, Crusade, 300 and 452; Baker, The Politics of Diplomacy, 435-37; Cockburn and Cockburn, Out of the Ashes, 24.
} 
the same time, there were some military officers who did not want to call for a ceasefire, instead urging that a push toward Baghdad could be achieved with minimal casualties on

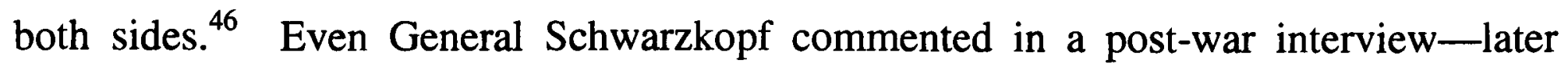
recanting after Colin Powell reminded him that he had an opportunity to air those views during the conflict—that his recommendation would have been to "continue the march" since the mission was not just to liberate Kuwait, but to destroy Iraq's offensive capabilities as well. ${ }^{47}$

President Bush, despite recognizing that there "hasn't been a clean end," felt that the original mission was accomplished and that pushing beyond it would be a political mistake, likely to result in the dissolution of the fighting coalition. ${ }^{48}$ Granting that the dangers inherent in continuing war were quite legitimate, what is nevertheless amazing is that there is scarcely even a mention of the specter of WMD use that remained the Iraqi wildcard, nor of the intense danger that Israel would attempt to unilaterally destroy the Iraqi WMD capability if missile attacks continued. Indeed, there seems to be no public record whatsoever indicating that this unconventional last-resort threat was a reason for the cessation of hostilities. ${ }^{49}$ This omission is particularly surprising given how frank some of the same decisionmakers were about expressing their concerns regarding Iraq's potential WMD threat in the lead-up to Operation Iraqi Freedom. ${ }^{50}$ Bush's advisors,

\footnotetext{
${ }^{46}$ Atkinson, Crusade, 475; Gordon and Trainor, The General's War, 423, 452, and 476. See also Kenneth M. Pollack, The Threatening Storm (New York: Random House, 2002), 46.

${ }^{47}$ R.W. Apple Jr., "Allies Destroy Iraqis' Main Force; Kuwait is Retaken After 7 Months," New York Times, 28 February 1991; Sterner, "Closing the Gate: The Persian Gulf War Revisited," 16. For Schwarzkopf's clarification, see H. Norman Schwarzkopf, with Peter Petre, It Doesn't Take a Hero (London: Bantam Press, 1992), 497 and Colin L. Powell, with Joseph E. Persico, A Soldier's Way (London: Arrow Books, 1995), 524.

${ }^{48}$ Bush and Scowcroft, A World Transformed, 489; James Dao, "Senior Bush Defends '9l Decision on Iraq," New York Times, 1 March 2003.

${ }^{49}$ William L. Dowdy and Barry R. Schneider, "On to Baghdad? Or Stop at Kuwait? A Gulf War Question Revisited," Defense Analysis vol. 13, no. 3 (December 1997): 323; Samuel Berger, Caspar Weinberger, and Joseph Biden, Hearing on Iraq before the Foreign Relations Committee, U.S. Senate, Washington D.C., 1 August 2002.

${ }^{50}$ Brent Scowcroft, "Don't Attack Saddam," Wall Street Journal, 15 August 2002; John Diamond, "Split over Iraq Grows more Public," USA Today, 19 August 2002. See also Avigdor Haselkorn, "Iraq's Bio-
} 
though, insist that Iraq's suspected CB arsenal played no part in the Gulf War cease-fire decision. $^{51}$ Such disregard is unusual given the nearly universal alarm over Iraq's CB potential both before and during the war, but military strategists probably discounted the Iraqi threat due to the rudimentary design of its warheads and delivery methods. ${ }^{52}$ Whether the cease-fire strategic assessment would have been the same had the U.S. officials been aware of the true magnitude of the BW threat they faced is another matter.

As with any counterfactual analysis, while some conclusions are possible, one cannot make a definitive determination of who was successful in deterring whom. Identifying deterrence failures, fortunately, is a much easier task. On the Iraqi side, it certainly appears that Saddam Hussein misjudged the United States, especially in regards to his initial warning that a conflict against Iraq would turn into the "mother of all battles." His menacing threats to create "columns of dead bodies" did not stop coalition forces from following through with Desert Storm and ejecting the Iraqis from Kuwait, even with the knowledge (albeit underestimated) of Iraq's CB capability. Moreover, U.S. forces were even confident enough to target Hussein himself with super penetrator munitions, a remarkably foolhardy objective if they truly feared WMD retaliation in the wake of a decapitation strike. ${ }^{53}$ American deterrence failures include Hussein choosing to initially invade Kuwait and hold his ground despite massive coalition forces aligned against him and American promises that his aggression would not stand. Significant controversy remains over how clear American threats were prior to the invasion of Kuwait, but regardless, it was an undeniably bold and aggressive move by Iraq against

\footnotetext{
Warfare Option: Last Resort, Preemption, or a Blackmail Weapon?" Biosecurity and Bioterrorism: Biodefense Strategy, Practice, and Science vol. 1, no. 1 (2003): 19-26.

${ }^{51}$ Scowcroft, phone interview; Baker, phone interview.

${ }^{52}$ Gordon and Trainor, The General's War, 414; Russell, "CIA's Strategic Intelligence in Iraq," 200; Michael R. Gordon, "Iraq Said to Plan Tangling the U.S. in Street Fighting," New York Times, 26 August 2002; Joby Warrick, "Uncertain Ability to Deliver a Blow," Washington Post, 5 September 2002.

${ }^{53}$ Byman, Pollack, and Waxman, "Coercing Saddam Hussein: Lessons from the Past," 141; Cockburn and Cockburn, Out of the Ashes, 34 .
} 
U.S. interests. ${ }^{54}$ Theoretically, it appears that Hussein believed that the asymmetries of interest involved were sufficient to enable a victory despite Baghdad's inferior military capabilities. Saddam Hussein also took a major gamble in flouting Baker's threat to hold accountable those who commit terrorism against coalition partners or attempt to destroy Kuwaiti oilfields. Hussein did it all, apparently without fear of the consequencesraining missiles down on Israeli and Saudi cities, directing a (mostly failed) global terrorism effort, and setting oil wells ablaze in the last days of the war (causing one of the worst environmental disasters ever). Even if Iraq was aware of the Bush administration's private decision not to employ nuclear weapons in the event of an Iraqi $\mathrm{CB}$ attack, this is still the most unambiguous failure of a specific deterrence threat in the war. $^{55}$

On the positive side of the ledger, it appears that U.S. deterrent threats made Hussein think twice about using his WMD; after all, Iraqi restraint prevailed amidst a sweeping and humiliating defeat in the land war. While some analysts speculate that non-use may have been due to interrupted communications or a lack of atropine injectors to prevent self-contamination, this cannot fully explain the absence of $\mathrm{CW}$ in the longrange Scud launches or the scarcity of $\mathrm{CW}$ in the Kuwaiti front if mass devastation was Iraq's strategic intention. ${ }^{56}$ It is much more likely that Hussein was concerned about an Allied nuclear response, or the prospect of being forcibly ousted from power. At the same time, it also looks as if Hussein was able to prevent the United States from directly challenging his regime, even when pushing on to Baghdad would not have been a

\footnotetext{
${ }^{54}$ Thomas L. Friedman, "Envoy to Iraq, Faulted in Crisis, Says She Warned Hussein Sternly," New York Times, 21 March 1991; Darwish and Alexander, Unholy Babylon, 268, 270, and 275; Janice Gross Stein, "Deterrence and Compellence in the Gulf, 1990-91: A Failed or Impossible Task?" International Security vol. 17, no. 2 (fall 1992): 152-156; Baram, "The Iraqi Invasion of Kuwait," 20; Cockburn and Cockburn, Out of the Ashes, 84; Said K. Aburish, Saddam Hussein, The Politics of Revenge (London: Bloomsbury, 2000), 282.

${ }^{55}$ Baker, The Politics of Diplomacy, 359; Bush and Scowcroft, $A$ World Transformed, 463.

${ }^{56}$ Sciolino, The Outlaw State, 262; Stephen D. Bryen, "Ironic Chemistry: The U.N. Boosts Saddam's Threat," Wall Street Journal, 9 December 2002.
} 
particularly taxing mission. There are many credible reasons for this restraint, and Iraq's CB may have been low on the list, but the fact that the coalition forces were equipped with gas masks and Israel inspected every missile attack for $\mathrm{CW}$ indicates an underlying fear that deterrence could fail. Even Colin Powell acknowledged that the possibility of a BW attack was his greatest nightmare during the war. ${ }^{57}$ How, then, can so many authors express such unqualified confidence that deterrence worked entirely in America's favor during the Gulf War? It seems more accurate to argue that both sides "rocked the boat" but neither was willing to tip it over.

\section{U.S.-North Korea (1993-94)}

Even though its nuclear research program dates back to the 1950 s, by the mid1980s North Korea's main communist benefactors-China and the Soviet Union-were providing less than certain defense support, leading the Democratic People's Republic of Korea (DPRK) to decide to secretly develop a nuclear weapons capability that could eventually serve as a deterrent against U.S. military intervention. ${ }^{58}$ During a covert refueling of their operating reactor in 1989, U.S. intelligence agencies estimate that the DPRK extracted and potentially reprocessed approximately $10-12 \mathrm{~kg}$ of plutonium, which is sufficient fissile material for at least two nuclear devices, depending on the

\footnotetext{
${ }^{57}$ Powell, A Soldier's Way, 503-504. Primakov, the Russian foreign minister, worried that Hussein suffered from a "masada complex." See Atkinson, Crusade, 283.

${ }^{58}$ Victor D. Cha, "The Second Nuclear Age: Proliferation Pessimism Versus Sober Optimism in South Asia and East Asia," Journal of Strategic Studies vol. 24, no. 4 (December 2001): 91. Of course, relations between the United States and North Korea were patchy throughout the Cold War. North Korea pursued a succession of dramatically erratic and brazen provocations, ranging from a commando raid on the South Korean Blue House (1968), the illegal seizure of an American electronic intelligence vessel named the USS Pueblo (1968), the downing of a navy EC-121 reconnaissance plane, killing 30 (1969), the brutal axe murder of two American officers over the pruning of a tree in the De-Militarized Zone (1976), and blowing up half of the South Korean cabinet with a bomb in Rangoon (1983), just to name a few. See Richard K. Betts, "What Will it Take to Deter the United States?" Parameters vol. XXI, no. 4 (winter 1995-96): 79, note 4 and Chuck Downs, Over the Line: North Korea's Negotiating Strategy (Washington D.C.: AEI Press, 1999), 119-162.
} 
design. $^{59}$ North Korea is also suspected of having produced a wide range of CB weapons-an estimated stockpile of 2,500 to 5,000 tons-and ballistic missiles with nearly intercontinental range. ${ }^{60}$ Overall, North Korea's WMD programs remain largely a mystery to the outside world, and are becoming even more so now that the DPRK has expelled the International Atomic Energy Agency (IAEA) inspectors from the country.

Diplomatically, ever since Reagan's "modest initiative" in 1988, the United States has sought to engage North Korea, all the while communicating a tough stance of firm resolve and deterrent power. Relations were improving dramatically in December of 1991, when North and South Korea concluded the Joint Declaration on the Denuclearization of the Korean Peninsula-now nullified-renouncing nuclear reprocessing or uranium enrichment and providing for mutual inspections. ${ }^{61}$ Unfortunately, after a promising initial meeting in New York in January of 1992, IAEA inspections later that year at Yongbyon uncovered evidence that three plutonium separations may have taken place in 1989, prompting accusations of cheating and demands for evidence of the missing plutonium. ${ }^{62}$ The United States presented satellite photos indicating further deception in February of 1993, enraging members of Congress and leading North Korea to announce its intention to withdraw from the NonProliferation Treaty (NPT). As Korea expert Don Oberdorfer put it, "The announcement of the withdrawal was treated as an incomprehensible act of defiance and an ominous sign that North Korea was hell-bent on the production of nuclear weapons."63 Some on Capitol Hill and in the American media began pressing for tough counter-action,

\footnotetext{
${ }^{59}$ Joseph S. Bermudez Jr., "Exposing North Korea's Secret Nuclear Infrastructure—Part Two," Jane's Intelligence Review vol. I1, no. 8 (August 1999): 42; Joseph S. Bermudez Jr., The Armed Forces of North Korea (New York: I.B. Tauris \& Co Ltd., 2001), 8.

${ }^{60}$ Joseph S. Bermudez Jr., "The Rise and Rise of North Korea's ICBMs," Jane's International Defense Review vol. 32, no. 7 (1 July 1999); Joseph S. Bermudez Jr., "The Democratic People's Republic of Korea and Unconventional Weapons," in Planning the Unthinkable, edited by Lavoy, Sagan, and Wirtz, 191.

${ }^{61}$ Marcus Noland, Avoiding the Apocalypse: The Future of the Two Koreas (Washington D.C.: Institute for International Economics, 2000), 147.

${ }^{62}$ Don Oberdorfer, The Two Koreas: A Contemporary History (London: Warner Books, 1997), 270.

${ }^{63}$ Ibid., 280.
} 
including the consideration of military options. ${ }^{64}$ Talks recommenced later that year, culminating in a joint statement that suspended the North Korean withdrawal threat one day before it was to take effect.

With this temporary reprieve in hand, the IAEA returned to its demand of full inspections, even though North Korea was actively seeking a middle ground that allowed a continuity of monitoring but forbade investigation into its prior potential diversion of fissile material. ${ }^{65}$ Some bargaining took place, as the United States raised the option of providing a proliferation-resistant light water reactor (LWR) and discussed the possible tradeoff of inspections in return for a suspension of the U.S.-South Korean military training known as Team Spirit Exercises. Talks were never consistent, however, and soon broke down amidst reports of a North Korean military buildup along the DeMilitarized Zone (DMZ) and a subsequent reconsideration of sanctions by the United States. With inspections still on hold, the IAEA announced that its monitoring equipment would soon run out of film and batteries, placing at risk the ability to ensure that North Korea would not remove more plutonium from the reactor. About this time, in November of 1993, President Clinton claimed on NBC's "Meet the Press" that "North Korea cannot be allowed to develop a nuclear bomb."66 South Korean President Kim Young Sam backed this assessment, stating: "North Korea's nuclear development should be stopped by all means." 67

Relations continued to plummet with the start of the new year, as the United States prepared to send reinforcements to the peninsula, including Patriot missiles, and

\footnotetext{
${ }^{64}$ Litwak, Rogue States and U.S. Foreign Policy, 210.

${ }^{65}$ Michael J. Mazarr, North Korea and the Bomb: A Case Study in Nonproliferation (London: Macmillan Press Ltd., 1995), 128.

${ }^{66}$ Quoted in Bermudez, "The DPRK and Unconventional Weapons," 189. Later, after various U.S. officials speculated that North Korea already had at least one bomb, the White House said that Clinton had misspoken. See Oberdorfer, The Two Koreas, 295.

${ }^{67}$ Quoted in Andrew Mack, "A Nuclear North Korea," World Policy Journal vol. XI, no. 2 (summer 1994): 28.
} 
began to plan for Team Spirit Exercises. A new visit by the IAEA in March of 1994 failed to guarantee that plutonium had not been reprocessed since the previous visit, but fortunately seemed able to preserve the continuity of its monitoring capabilities. ${ }^{68}$ Talks remained stymied and became heated, as a North Korean official broadcast declared that the new military steps by the United States and South Korea had "pushed the situation to a very dangerous brink of war." ${ }^{, 69}$ However, the most dramatic remark came from the North Korean negotiator at Panmunjom, Park Yong Su, who made the now famous warning to his South Korean counterpart: "Seoul is not far from here. If a war breaks out, it will be a sea of fire. Mr. Song, it will probably be difficult for you to survive."70 As in the dialogue leading up to Desert Storm, the United States responded forcefully to this deterrent threat, with Secretary of Defense William Perry issuing a sharp warning that the United States intended to stop North Korea from developing a substantial arsenal of nuclear weapons even at the potential cost of another war on the Korean peninsula. ${ }^{71}$

As if tensions were not high enough, crisis struck in April 1994 when Kim Il Sung announced that North Korea would shut down the major reactor at Yongbyon a second time so that spent fuel rods from its core could be removed, potentially erasing evidence of its past defueling permanently. Surprisingly, Kim coupled this revelation with two remarkably conciliatory interviews in which he disowned the "sea of fire" comment by calling it "a mistake," renounced any nuclear ambitions, and called for a recommencement of talks with the United States. ${ }^{72}$ Focusing on North Korea's actions rather than its words, the United States proved that Perry's statement was far from empty rhetoric; along with harsh economic sanctions, subsequent accounts now reveal that the

\footnotetext{
${ }^{68}$ Mazarr, North Korea and the Bomb, 155.

${ }^{69}$ Quoted in T. R. Reid, "North Korea Warns of 'Brink of War," Washington Post, 23 March 1994.

${ }^{70}$ Quoted in J.F.O. McAllister, "Pyongyang's Dangerous Game," Time, 4 April 1994. See also Oberdorfer, The Two Koreas, 304.

${ }^{71}$ R. Jeffrey Smith, "Perry Sharply Warns North Korea," Washington Post, 31 March 1994.

${ }^{72}$ Quoted in Leon V. Sigal, Disarming Strangers: Nuclear Diplomacy with North Korea (Princeton, NJ:

Princeton University Press, 1998), 111.
} 
United States was also contemplating a preemptive attack-readying a war plan that called for the precision bombing of the Yongbyon facility, hoping to destroy it and entomb the plutonium without causing a meltdown. ${ }^{73}$ As the United States considered its military options, the IAEA responded to North Korea by emphasizing that it would be imperative for IAEA inspectors to have complete access during the defueling to ensure that none of the fuel rods were diverted. It also requested to take samples from the reactor's fuel rods to determine the amount of fuel unloaded in the 1989 shutdown. $^{74}$ The DPRK agreed to allow inspectors to view the defueling, but refused the sampling request.

When unloading of the fuel rods began in mid-May, proceeding at a pace that made proper IAEA monitoring impossible, chief inspector Hans Blix declared that confidence over the control of reactor fuel had been irreversibly lost. With this news, the pressure rose further and the United States pushed its case for economic sanctions to the international community, stating that the DPRK had "crossed the point of no return."75 North Korea promptly responded that it would "rather accept a war" than give up its defense secrets, and that "sanctions mean war, and there is no mercy in war." days later the U.S. ambassador ordered his family out of Seoul and met with the commander of U.S. forces in Korea to map out evacuation plans. ${ }^{77}$ Relations were in a free-fall, as North Korea withdrew from the IAEA and again hinted at leaving the NPT.

\footnotetext{
${ }^{73}$ Ashton B. Carter and William J. Perry, Preventive Defense: A New Security Strategy for America (Washington D.C.: Brookings Institution Press, 1999), 128; Ashton B. Carter and William J. Perry, "Back to the Brink," Washington Post, 20 October 2002; Selig S. Harrison, Korean Endgame: A Strategy for Reunification and U.S. Disengagement (Princeton, NJ: Princeton University Press, 2002), 122; William J. Perry and Ashton B. Carter, "The Crisis Last Time," New York Times, 19 January 2003.

${ }^{74}$ Paul Leventhal and Steven Dolley, "The North Korean Nuclear Crisis," Nuclear Control Institute, 16 June 1994. See http://www.nci.org/n/nkib2.htm.

${ }^{75}$ Quoted in Leventhal and Dolley, "The North Korean Nuclear Crisis."

${ }^{76}$ Quoted in Oberdorfer, The Two Koreas, 311.

${ }^{77}$ Harrison, Korean Endgame, 117.
} 
Conservatives in the American press were outraged, and began another strong push for the consideration of military strikes. ${ }^{78}$ The U.S. military command was indeed weighing over that very option in a major strategy session, and on 18 June Clinton met with his national security advisors to finalize an "Action Plan" for a substantial expansion of American military forces in and near Korea. ${ }^{79}$ Around this time former President Jimmy Carter was en route to Pyongyang on a mission to try and avert the looming war, and upon meeting with Kim Il Sung the two worked out a plan to keep inspectors in place and start a new round of talks. ${ }^{80}$ Perry testified to Congress that he was just in the process of presenting several alternative build-up plans to President Clinton for his final approval at the very hour they got word from Carter that the North Koreans were prepared to sit down and negotiate an agreement. ${ }^{81}$ Though many in Washington were infuriated by Carter's intervention, it certainly came at a fortuitous time and led to a round of talks that eventually culminated in the Agreed Framework in October of 1994.

Most analysts and the direct participants agree that the danger of war during these two months was quite high. Robert Litwak opines: "Given the mutual mistrust and the absence of regular contact between North Korea and the United States, the May-June 1994 crisis carried a significant risk of inadvertent military escalation through misperception and miscalculation." 82 Since the conflict was defused before it could get too far out of hand, it is difficult to judge how actively deterrence-and compellencewere at play. On the one hand, a DPRK preemptive attack seemed extremely unlikely, despite the comment of one North Korean colonel to a U.S. officer that "We are not

\footnotetext{
${ }^{78}$ Charles Krauthammer, "Get Ready for War," Washington Post, 3 June 1994; Sigal, Disarming Strangers, 117.

${ }^{79}$ Harrison, Korean Endgame, 118.

${ }^{80}$ See Douglas Brinkley, The Unfinished Presidency (New York: Penguin Putnam, 1998), 400-410.

${ }^{81}$ William Perry, Hearing on Security Implications of the Nuclear Agreement with North Korea before the Armed Services Committee, U.S. Senate, Washington D.C., 26 January 1995.

${ }^{82}$ Litwak, Rogue States and U.S. Foreign Policy, 216.
} 
going to let you do a buildup. ${ }^{, 83}$ On the other hand, the likelihood of an unprovoked U.S. military attack appeared equally remote, especially given U.S. casualty estimates of a prospective war. Perry noted that he and General Shalikashvili (the chairman of the Joint Chiefs of Staff) had concluded that a preemptive attack "was very likely to incite the North Koreans to launch a military attack on South Korea," effectively removing the military option from further consideration. ${ }^{84}$ There were certainly not many attractive options, and even the alternative of sanctions carried a very real threat of devastating war. In a hearing before Congress, Perry testified that he took the DPRK "sea of flames" rhetoric seriously enough to lead him to recommend to the president that any imposition of sanctions on North Korea should be accompanied by an immediate augmentation of U.S. military forces in the Republic of Korea. ${ }^{85}$

Essentially, using our theoretical framework, the DPRK successfully communicated the impression (feigned or actual) of irrationality, leading to the quite rational outcome of deterrence power against the United States. Though North Korea certainly was deficient in overall strategic capabilities and could not threaten the U.S. homeland directly, its abundant artillery batteries located within striking distance of Seoul (and therefore American troops as well) created a rough conventional parity that was worrisome enough. Moreover, the DPRK had sufficient compelling interest in protecting its nascent nuclear program and avoiding sanctions that would further cripple its economy to make the threat of all-out war credible. In the final analysis, to the United

\footnotetext{
${ }^{83}$ Quoted in Oberdorfer, The Two Koreas, 326. There is some evidence that the North Korea military was moving to a war footing, conducing unusual training exercises in response to the U.S. reinforcement measures. See Mitchell Reiss, Bridled Ambition (Washington D.C.: Woodrow Wilson Center Press, 1995), 271.

${ }^{84}$ Steven Greenhouse, "Perry Says U.S. Considered Bombing North Korean Reactor," The Houston Chronicle, 25 January 1995; Carter and Perry, Preventive Defense, 128-29. Despite this conclusion, in November 2002 former president Bill Clinton reportedly told an audience at the University of California's Davis campus that eight years ago, "we literally threatened to attack and planned to attack North Korea if they didn't end their nuclear weapons program." See Carl Limbacher, "Clinton: I Threatened to Attack North Korea," NewsMax.com, 24 November 2002.

${ }^{85}$ Perry, Hearing on North Korea, 26 January 1995.
} 
States, the imperative to discover North Korea's potential to produce a handful of nuclear weapons was simply not worth the risk of a major conflict. U.S. Ambassador Laney and General Luck both saw a diplomatic deal as the most prudent option, commenting: "Why are we going to risk killing a million people? A bomb or two can't even do that." ${ }^{, 86}$ In fact, Perry implied a tacit consent of a limited DPRK arsenal, conceding in April of 1994: "Our policy right along has been oriented to try to keep North Korea from getting a significant nuclear-weapon capability." Regarding the one to two weapons the U.S. already suspected the DPRK of possessing, Perry said: "We don't know anything we can do about that. What we can do something about, though, is stopping them from building beyond that. ${ }^{, 87}$

At the same time, if we reverse perspective, it becomes apparent that the United States had a fair amount of deterrence leverage itself. Or, more accurately, the United States had a strong coercive stance that combined elements of compellence (the demand that North Korea freeze its nuclear program) and deterrence (a warning not to attack South Korean or U.S. forces). ${ }^{88}$ Of course, we will never know how events would have played out if Carter had not intervened, but Perry and his colleague Ashton Carter insist that they were prepared to risk war if the Agreed Framework had fallen through. Most U.S. officials involved in the crisis likewise maintain that the North Korean threat of war did not deter them from pursuing their objective of restraining further DPRK nuclear development. $^{89}$ North Korea did ultimately have to offer concessions to reach a compromise, implying that there was some fear that continued "stonewalling" on their

\footnotetext{
${ }^{86}$ Quoted in Sigal, Disarming Strangers, 122.

${ }^{87}$ Quoted in Mark Thompson, "Well, Maybe a Nuke or Two," Time, 11 April 1994.

${ }^{88}$ Yuen Foong Khong, "Strategic Coercion in East Asia: The Cases of Cambodia and North Korea," in Strategic Coercion: Concepts and Cases, edited by Lawrence Freedman (Oxford: Oxford University Press, 1998), 129.

${ }^{89}$ Joel Wit, interview with author, 18 August 2003; William Perry, phone interview with author, 21 August 2003; Robert Gallucci, phone interview with author, 22 August 2003. For a more in-depth assessment, see William M. Drennan, "Nuclear Weapons and North Korea: Who's Coercing Whom?" in The United States and Coercive Diplomacy, edited by Robert J. Art and Patrick M. Cronin (Washington D.C.: United States Institute of Peace Press, 2003).
} 
part could indeed lead to a military strike on Yongbyon or international sanctions, despite the threat of war in response.

Especially given the almost total lack of knowledge of the DPRK leadership, it is quite hard to compare which side felt the greater deterrence pressure; for two states facing the imminent prospect of catastrophic war, they both seemed willing to stand firm over certain baseline negotiating positions no matter what. Deterrence theory would generally predict a more cautious approach, though this was perhaps an instance of both sides employing commitment techniques and thereby locking themselves into positions from which it became increasingly difficult to make a graceful retreat. Theory aside, even if deterrence worked successfully in this case, the potential for war in the spring of 1994 was disturbingly high. Robert Gallucci, the chief negotiator of the Agreed Framework with North Korea, said recently: "There was every indication at the time that President Clinton would have used force rather than allow the North Koreans to separate more plutonium to produce nuclear weapons." ${ }^{90}$ Perry himself said in a 1999 news conference: "We were literally within a day of imposing severe sanctions on North Korea-sanctions that they said would be equivalent to an act of war. We were within a day of making major additions to our troop deployments in Korea, and we were about to undertake an evacuation of American civilians from Korea."91 Most telling of all, Lieutenant General Howard Estes, the senior U.S. Air officer in Korea, admitted: "Inside we all thought we were going to war." 92

Perhaps both the United States and North Korea were engaged in a high-stakes bluff and neither would have actually stayed the course into conflict. Perhaps too Iraq

\footnotetext{
${ }^{90}$ Quoted in David E. Sanger and James Dao, "North Korea Says It Regains Access to Its Plutonium," New York Times, 23 December 2002.

${ }^{91}$ Quoted in Kim Myong Chol, "Kim Jong Il's Military Strategy for Reunification," Comparative Strategy vol. 20 (2001): 404.

${ }^{92}$ Quoted in Oberdorfer, The Two Koreas, 306.
} 
would never have resorted to WMD, even with the coalition forces marching on Baghdad, as turned out to be the case in Iraqi Freedom. No matter how one interprets the evidence, however, these cases are certainly not a ringing endorsement for the power of deterrence in the post-Cold War era. Kenneth Waltz's assurance that "not much is required to deter" begins to ring a little hollow when applied to real-world conflicts. ${ }^{93}$ More important, these two examples are hardly isolated events; rather, they are part of a definitive trend, an evolution in the way that weaker states and terrorist groups choose to counterbalance the conventional superiority of the United States. Virtually every other conflict in the past decade-ranging from the Bosnian War to Operation Desert Foxhas involved open references to asymmetric unconventional warfare. ${ }^{94}$ Iran has also embarked on an ambitious effort to offset American military advantages, working on producing anti-ship technology, long-range missiles, and even nuclear weapons. ${ }^{95}$ During the campaign in Afghanistan, there were numerous newspaper accounts of $\mathrm{Al}$ Qaeda trying desperately to develop WMD. Subsequently, raids on various labs and hideouts have revealed bioterror manuals, videos of experiments with chemical agents, a diagram for a "dirty" radiological bomb, and even low-grade uranium-238. ${ }^{96}$ Even

\footnotetext{
${ }^{93}$ Waltz, in The Spread of Nuclear Weapons, 22.

${ }^{94}$ Philip L. Ritcheson, "Proliferation and the Challenge to Deterrence," Strategic Review vol. XXIII, no. 2 (spring 1995): 42; Henning Riecke, "NATO's Non-Proliferation and Deterrence Policies: Mixed Signals and the Norm of WMD Non-Use," Journal of Strategic Studies vol. 23, no. 1 (March 2000): 46; Robert D. Critchlow, "Whom the Gods Would Destroy: An Information Warfare Alternative for Deterrence and Compellence," Naval War College Review vol. LIII, no. 3 (summer 2000): 27.

${ }^{95}$ Iran's Medium Range Ballistic Missile program has benefited from considerable Russian assistance, but its nuclear program has received intense scrutiny recently. For further details on Iran's WMD and missile build-up, see: Shahram Chubin, "Does Iran Want Nuclear Weapons?" Survival vol. 37, no. 1 (spring 1995): 97; Cordesman, Iran's Military Forces in Transition, 4; Michael Dobbs, "A Story of Iran's Quest for Power," Washington Post, 13 January 2002; Scott Peterson, "Iran's Nuclear Challenge: Deter, not Antagonize," The Christian Science Monitor, 21 February 2002; Joby Warrick and Glenn Kessler, "Iran's Nuclear Program Speeds Ahead," Washington Post, 10 March 2003; Massimo Calabresi, "Iran's Nuclear Threat," Time, 17 March 2003; Joby Warrick, "Enriched Uranium Traces Found in Iran," Washington Post, 19 July 2003.

${ }^{96}$ Colum Lynch, "Bin Laden Sought Uranium, Jury Told," Washington Post, 8 February 2001; Mike Boettcher, "Evidence Suggests Al Qaeda Pursuit of Biological, Chemical Weapons," CNN, 14 November 2001; Bob Woodward, Robert G. Kaiser, and David B. Ottaway, "U.S. Fears Bin Laden Made Nuclear Strides," Washington Post, 4 December 2001; Judith Miller, "Qaeda Videos Seem to Show Chemical Tests," New York Times, 19 August 2002; Neil Doyle, "Al Qaeda Nukes Are Reality, Intelligence Says," Washington Times, 28 October 2002; Associated Press, "Bin Laden Said to Have Sought Nuclear Arms,"
} 
though reporters have quoted bin Laden as only desiring chemical and nuclear weapons to deter American use of the same, Al Qaeda's development of such weapons would be of grave concern. ${ }^{97}$ Terrorists do not seem to be following the old dictum that they "want a lot of people watching and not a lot of people dead." There is simply not enough confidence in deterrence to allow leaders and states with a declared and demonstrated willingness to attack innocent Americans to threaten such weapons. The next chapter will examine the strategic consequences of this transformation of deterrence and how the United States is responding.

Baltimore Sun, 30 December 2002; Josh Meyer, "Al Qaeda Feared to Have 'Dirty Bombs," Los Angeles Times, 8 February 2003.

${ }^{97}$ David Willman and Alan C. Miller, "Nuclear Threat is Real, Experts Warn," Los Angeles Times, 11 November 2001; Bill Gertz, "CIA Says Al-Qaeda Ready to Use Nukes," Washington Times, 3 June 2003. ${ }^{98}$ Brian M. Jenkins, "Will Terrorists Go Nuclear?" Orbis vol. 29, no. 3 (fall 1985): 511 (italics his). 


\section{Chapter 4}

\section{$\underline{\text { Strategic Considerations and Counterproliferation Options }}$}

The preceding chapters suggest that deterrence is in a state of flux, both theoretically and practically. This does not mean that it ceases to play a role in world affairs merely because it is a fallible concept; the United States will inevitably rely upon deterrence to some degree, especially for territorial defense of allies and the homeland. If anything, the increasing salience of WMD will make efforts at deterrence even more frequent and pronounced. The U.S. National Security Strategy to Combat Weapons of Mass Destruction states:

The United States will continue to make clear that it reserves the right to respond with overwhelming force-including through resort to all of our options-to the use of WMD against the United States, our forces abroad, and friends and allies. ${ }^{1}$

This was certainly the case in the lead-up to Iraqi Freedom, when two senior U.S. Senators disclosed that U.S. officials had warned Saddam Hussein that he and his country could face "annihilation" if Iraq employed WMD during war. ${ }^{2}$ In reality, as in Desert Storm, the American options for retaliation would have been rather limited given the profound reluctance to resort to nuclear weapons and the already extensive conventional bombing plans. ${ }^{3}$ U.S. focus instead shifted to attempting to deter Iraqi leaders from carrying out orders to use their $\mathrm{CB}$ arsenal, based on an intense campaign involving speeches, leaflets and even e-mails that threatened war crimes trials for those

\footnotetext{
${ }^{1}$ U.S. Government, National Security Strategy to Combat Weapons of Mass Destruction (Washington D.C.: December 2002), 3.

2 Joyce Howard Price, "U.S. Reprisal to be 'Annihilation,"” Washington Times, 9 September 2002.

${ }^{3}$ Bradley Graham, “As U.S. Girds for Worst in Iraq, Retaliation Isn't Clear-Cut Issue,” Washington Post, 29 January 2003.
} 
responsible. ${ }^{4}$ President Bush gave several speeches reinforcing this message, declaring in one:

An Iraqi regime faced with its own demise may attempt cruel and desperate measures. If Saddam Hussein orders such measures, his generals would be well advised to refuse those orders. If they do not refuse, they must understand that all war criminals will be pursued and punished. ${ }^{5}$

Similar signaling is also taking place vis-à-vis North Korea, as the commander of American forces in the Pacific requested additional air and naval forces specifically to strengthen the U.S. deterrent on the peninsula. ${ }^{6}$

Deterrence is a constant presence in international relations, even without such explicit warnings, and some analysts argue that the immense conventional and strategic weapon advantages the United States enjoys will be more than sufficient to convince any adversary that the costs of aggressive action would far outweigh any benefits. ${ }^{7}$ Any threat by a rogue nation to use WMD would lack credibility because carrying it out would invite devastating and unacceptable retaliation. According to this view, as outlined in Chapter Two, if American resolve to follow through with a military operation under the shadow of WMD is in question, the United States should either find ways to strengthen the perception of U.S. interests in the region or develop greater military

\footnotetext{
${ }^{4}$ Thomas D. Grant, "For an Iraq Amnesty," Washington Post, 20 August 2002; Walter Pincus, "U.S. Effort Aimed at Iraqi Officers," Washington Post, 30 September 2002; James Drummond and Edward Alden, "Rumsfeld Orders Extra Forces to Mideast," Financial Times, 13 January 2003; Thom Shanker and David Johnston, "U.S. Lists Iraqis to Punish, or to Work With," New York Times, 26 February 2003.

${ }^{5}$ George W. Bush, Remarks on Iraq, Cincinnati, Ohio, 7 October 2002; see also George W. Bush, "Taking Action to Strengthen Small Business," St. Louis, Missouri, 22 January 2003.

${ }^{6}$ Eric Schmitt and David E. Sanger, "Admiral Seeks Deterrent Force in Korea Crisis," New York Times, 1 February 2003; David E. Sanger and Thom Shanker, "U.S. Sending 2 Dozen Bombers in Easy Range of North Koreans," New York Times, 5 March 2003.

${ }^{7}$ Stephen M. Walt, "Containing Rogues and Renegades: Coalition Strategies and Counterproliferation," in The Coming Crisis: Nuclear Proliferation, U.S. Interests, and World Order, edited by Victor A. Utgoff (Cambridge, MA: MIT Press, 2000), 211; Jan Lodal, The Price of Dominance: The New Weapons of Mass Destruction and Their Challenge to American Leadership (New York: Council of Foreign Relations, 2001), 100; James H. Lebovic, "The Law of Small Numbers: Deterrence and National Missile Defense," The Journal of Conflict Resolution vol. 46, no. 4 (August 2002): 465; John J. Mearsheimer and Stephen M. Walt, “An Unnecessary War," Foreign Policy no. 134 (January/February 2003): 50-59.
} 
capabilities to compensate. ${ }^{8}$ Given that backing down in the face of such a threat would surely entice other countries to develop and more boldly wield such weapons, it would seem that the United States would be loath to shrink from such a test of its credibility. ${ }^{9}$

The difficulty with this perspective is that the potency of WMD is challenging the fundamentals of the classic deterrence calculus. The United States can hardly make its strategic forces more fearsome, and even with its current nuclear arsenal there are substantial moral restraints against its use in all but the most extreme of situations. As a result, the excessive power of American nuclear weapons may ironically make an adversary's threat to use WMD—especially $\mathrm{CB}$-more credible; expecting that a U.S. counterattack is likely to remain conventional, a regional aggressor may decide that using nonconventional weapons to complement an asymmetric military strategy is worth the risk. ${ }^{10}$ In such an event, the United States would probably still follow through with some form of retaliation and expand its efforts to win the war, but that would be of little solace once WMD had been used.

More importantly, a rogue state may not ever need to actually employ WMD in order to achieve the desired effect; all that is necessary is for an adversary to make the expected costs of action unacceptable to U.S. leaders. ${ }^{11}$ The overall likelihood of WMD escalation may be quite low, but if the interests involved are substantially in a rogue state's favor, the United States may not want to take the chance. As Thomas Schelling

\footnotetext{
${ }^{8}$ Dean Wilkening and Kenneth Watman, Nuclear Deterrence in a Regional Context (Santa Monica, CA: RAND, 1995), 21-22.

${ }^{9}$ Barry R. Posen, "U.S. Security Policy in a Nuclear-Armed World, or What if Iraq Had Had Nuclear Weapons?" in The Coming Crisis, edited by Utgoff, 158; Victor Utgoff, "The Coming Crisis: Nuclear Proliferation, U.S. Interests, and World Order-A Combined Perspective," in The Coming Crisis, edited by Utgoff, 290.

${ }^{10}$ Lewis A. Dunn, "Rethinking the Nuclear Equation: The United States and the New Nuclear Powers," The Washington Quarterly vol. 17, no. 1 (winter 1994): 10. This was in fact the strategy of several "red teams" that participated in a recent U.S. war gaming exercise. See Frank Tiboni, "War Game Stuns U.S. Strategists," Defense News, 12 May 2003.

${ }^{11}$ Stephen J. Cimbala, Nuclear Strategy in the Twenty-First Century (Westport, CT: Praeger Publishers, 2000), 191; Keith B. Payne, Deterrence in the Second Nuclear Age (Lexington, KY: The University Press of Kentucky, 2001), 30.
} 
has observed, deterrence strategy "...is not concerned with the efficient application of force but with the exploitation of potential force." 12 For instance, nuclear states during the Cold War were never able to prove that retaliation was certain in the event of military action against them, but the unacceptable consequences of such an event made an assessment that the state would "probably not" use nuclear weapons become the functional equivalent of determining that they "possibly could" in the eyes of the opposing power. ${ }^{13}$ In fact, the analogy to the Cold War can be quite informative if we recognize that in the present day the roles are reversed. Whereas before the United States and NATO sought to prevent a Soviet conventional attack on Europe by threatening an apparently suicidal counterstrike in response, today a whole range of regional powers are developing WMD to achieve very similar ends against the United States. Keith Payne queries: "If we expected Soviet leaders to discount their capability to deter NATO nuclear escalation while fighting on NATO territory, can we now expect our own deterrence policies of the second nuclear age to give us such a capability vis-àvis regional rogues?"14

In this way, paradoxically, the potential for deterrence failure against a rogue state may be the very condition for deterrence success against America. In the gray areas of foreign policy, U.S. officials will have to make agonizing decisions by balancing the value of a particular international action against the risk that it will result in a breakdown of deterrence and the possibility of disastrous harm. As an illustration, the Cuban Missile Crisis of 1962 (during which the United States had an overwhelming advantage in local conventional and nuclear capability) demonstrated how constrained decisionmakers can feel when confronted with even a low probability of a devastating

\footnotetext{
${ }^{12}$ Thomas C. Schelling, The Strategy of Conflict (Cambridge, MA: Harvard University Press, 1960), 5 (italics his).

${ }^{13}$ Avery Goldstein, Deterrence and Security in the $21^{\text {st }}$ Century: China, Britain, France, and the Enduring Legacy of the Nuclear Revolution (Stanford, CA: Stanford University Press, 2000), 46 and 133.

${ }^{14}$ Payne, Deterrence in the Second Nuclear Age, 33.
} 
response to military action. President Kennedy and his advisors ultimately ruled out the option of air strikes on missile sites in Cuba because of the possibility that a few nuclear weapons might survive the attack. ${ }^{15}$ Today, the proliferation of weapons of mass destruction has the potential to turn international relations into a perpetual Cuban Missile crisis, with a constant progression of brinksmanship tests that will strain deterrence to its limits.

U.S. strategic thinkers are quite aware of this tension. According to the National Security Strategy: "These weapons may also allow these states to attempt to blackmail the United States and our allies to prevent us from deterring or repelling the aggressive behavior of rogue states." ${ }^{\prime 16}$ The mere possession of WMD might be sufficient to splinter a coalition, complicating over-flight rights, aircraft basing, and force projection operations in a regional conflict. American allies, often closer to the war zone than the United States, may have significantly different risk tolerances or vulnerabilities, making them more susceptible to coercive tactics. ${ }^{17}$ Operationally, American deployment strategies and warfighting maneuvers could be severely constrained by the hazards of presenting fixed targets, potentially reducing military effectiveness. ${ }^{18}$ Moreover, once war has begun, WMD capabilities may be instrumental in limiting American or allied war aims, given the possibility of a last resort attack.

\footnotetext{
${ }^{15}$ Ibid., 25.

${ }^{16}$ U.S. Government, The National Security Strategy of the United States of America (Washington D.C.: September 2002), 15.

${ }^{17}$ Barry R. Schneider, "Strategies for Coping with Enemy Weapons of Mass Destruction," Airpower Journal (Special Edition 1996): 37; Robert W. Chandler with Robert J. Trees, Tomorrow's War, Today's Decisions: Iraqi Weapons of Mass Destruction and the Implications of WMD-Armed Adversaries for Future U.S. Military Strategy (McLean, VA: AMCODA Press, 1996), xix.

${ }^{18}$ Robert G. Joseph, "Regional Implications of NBC Proliferation," Joint Forces Quarterly no. 9 (autumn 1995): 68 .
} 
The point is not that regional opponents are undeterrable, but that they should be considered as only potentially deterrable. ${ }^{19}$ Much will depend on context, for the United States is likely to have considerably more confidence in deterring the use of WMD when responding to overt aggression (as in Desert Storm) than when attempting to compel some form of disarmament or policy action (as in North Korea). Perhaps the solution is for the United States to adopt a defensive mindset and avoid situations that would result in a rogue state feeling driven to make such grave threats. Ideally, if all states were fearful of impinging on one another's vital interests, a relationship Hedley Bull described as a "unit-veto system" would be in existence, wherein every state practiced mutual deterrence against all others. ${ }^{20}$ Rather than turn to preemption without concrete evidence of hostile intent, the United States could set boundaries that would keep dangerous states in their "box." After all, containment seems to have worked with the Soviet Union and hence many would like to see it applied to rogue states as well. ${ }^{21}$ Perhaps the United States could, as Stephen Walt argues, combine deterrence with reassurance and promise not to overthrow a suspect regime as long as it abstains from aggression. ${ }^{22}$ Kenneth Waltz essentially advocates this viewpoint, accepting that with nuclear proliferation the United States "militarily punishing small countries for behavior we dislike would become much more perilous." 23 Such an answer is far less satisfactory, though, if the behavior America "dislikes" is a rogue state providing sanctuary for international

\footnotetext{
${ }^{19}$ Lewis Dunn, Peter Lavoy, and Scott Sagan, "Conclusions: Planning the Unthinkable," in Planning the Unthinkable: How New Powers Will Use Nuclear, Biological, and Chemical Weapons, edited by Peter R. Lavoy, Scott D. Sagan, and James J. Wirtz, (Ithaca, NY: Cornell University Press, 2000), 257.

${ }^{20}$ Hedley Bull, The Anarchical Society, ${ }^{\text {nd }}$ Edition (London: Macmillan Press Ltd., 1995), 116. See also Morton A. Kaplan, System and Process in International Politics (New York: John Wiley \& Sons, Inc., 1957), 50 and Pierre Gallois, The Balance of Terror: Strategy for the Nuclear Age (Boston, MA: Houghton Mifflin Company, 1961), 8-9.

${ }^{21}$ Robert S. Litwak, Rogue States and U.S. Foreign Policy: Containment after the Cold War (Baltimore, MD: Johns Hopkins University Press, 2000), 152; William Raspberry, "Our Insane Focus on Iraq," Washington Post, 9 September 2002; New York Times, "In Defense of Deterrence," 10 September 2002. ${ }^{22}$ Walt, "Containing Rogues and Renegades," 224.

${ }^{23}$ Kenneth N. Waltz, "Waltz Responds to Sagan," in Scott D. Sagan and Kenneth N. Waltz, The Spread of Nuclear Weapons: A Debate (New York: W.W. Norton \& Company, 1995), 111.
} 
terrorist groups, plotting a surprise attack, or pursuing limited coercive military operations against a neighboring country that might not clearly qualify as aggression.

A non-interference pact of the kind Stephen Walt suggests could allow a rogue state to clandestinely build up its WMD arsenal until the point that it felt confident enough to challenge U.S. interests. In fact, rogue states may actually become more aggressive if they feel that their WMD have neutralized the U.S. strategic arsenal, calculating that they enjoy a conventional advantage over local adversaries. The great unknown is whether the United States would be deterred in such an instance from bringing its immense military assets to bear against a regional foe that may have much more at stake in the conflict-and therefore perhaps a more credible threat to escalate to WMD. ${ }^{24}$ The strategic merits of Operation Iraqi Freedom aside, it is worth considering how much stronger international opposition-and indeed, U.S. domestic resistancewould have been if Saddam Hussein had provided evidence of possessing a nuclear weapon. The almost complete unwillingness to consider a military response to North Korea's growing nuclear threat provides a telling comparison.

Given these examples, nuclear optimists like Kenneth Waltz would likely respond by pointing out the fact that neither Iraq nor North Korea has instigated a war since fighting with the United States, perhaps proving that deterrence can restrain even the most dangerous regimes. If such states ever did choose to commit aggression on a significant scale, they would have little hope of deterring the United States, and even less reason to actually resort to WMD given the all but certain consequences of such a choice. Patrick Morgan remarked: "[Rogue states] are not going to find it easy to deter us (the U.S., the Security Council, the West, etc.) if they develop WMD-not if they are

\footnotetext{
${ }^{24}$ Alexander L. George and Richard Smoke, Deterrence in American Foreign Policy: Theory and Practice (New York: Columbia University Press, 1974), 111; Charles L. Glaser and Steve Fetter, "National Missile Defense and the Future of U.S. Nuclear Weapons Policy," International Security vol. 26, no. 1 (summer 2001): 67.
} 
sufficiently provocative and we are exceedingly determined." ${ }^{25}$ However, the dilemma lies in determining what level of aggression qualifies as significant or "provocative," and whether the United States is determined enough to accept the risk that rogue states will be "rational" and refrain from using WMD. Certain military preparations or operations can be ambiguous as to their aggressive nature, and low intensity conflicts could further obfuscate attribution as to which side is acting in a defensive manner and therefore has the "upper hand" in deterrence. For instance, the North Korean nuclear program does not inherently pose a direct threat to the United States, but certainly has security implications if atomic weapons are eventually sold on the black market. States with deficient military capabilities are often adept at "designing around" deterrent strategies, making only gradual advances so that no single step on its own would merit retaliation. ${ }^{26}$ In effect, extending mutually assured destruction on a multilateral basis would open a Pandora's box of uncertainty over what would or would not be defended, with each side hoping-or gambling — that the other had enough restraint to keep the fighting on a conventional level. Given that there were extremely dangerous crises even during the Cold War, when most of the major powers were fundamentally status quo actors, it is very difficult to argue that expanding such a framework could be sustainable or stable over the long run.

As the Cold War demonstrated, mutually assured destruction does not mean that conflict ceases to exist, merely that it generally goes "under the table" and takes on the form of mini-conflicts, terrorism, and proxy wars. Rogue states are still capable of causing a great deal of damage without resorting to overt aggression, perhaps through attempts at blackmail or interference in regional politics. The image of a nuclear-armed

\footnotetext{
${ }^{25}$ Patrick M. Morgan, Deterrence Now (Cambridge: Cambridge University Press, 2003), 292.

${ }^{26}$ George and Smoke, Deterrence in American Foreign Policy. See also Elli Lieberman, Deterrence

Theory: Success or Failure in Arab-Israeli Wars? McNair Paper No. 45 (Washington D.C.: Institute for National Strategic Studies, National Defense University, October 1995), 35 and 58.
} 
Nazi Germany and the potential for internal devastation argues strongly against a reactive strategy based purely in response to the use of force externally. ${ }^{27}$ Moreover, as occurred in Afghanistan, granting a rogue state a form of sanctuary could allow its government or terrorist networks within it to bide their time in preparing a surprise attack that would have as little warning as potential for being deterred. Such a fear was quite prominent in the U.S. Congressional authorization of force against Iraq, which stated:

Whereas Iraq's demonstrated capability and willingness to use weapons of mass destruction, the risk that the current Iraqi regime will either employ those weapons to launch a surprise attack against the United States or its Armed Forces or provide them to international terrorists who would do so, and the extreme magnitude of harm that would result to the United States and its citizens from such an attack, combine to justify action by the United States to defend itself. ${ }^{28}$

Whether or not such concerns were valid, or whether the eventual American response was justified, the strategic reality of global threats that have no warning demands a reassessment of relying predominately on deterrence as the foundation of national security.

In sum, in an era of mass globalization, enabling a few individuals to kill thousands and potentially millions, perhaps through covert means, the containment "box" is becoming more porous than ever-hardly a sturdy barrier against creeping regional threats and terrorism. Unfortunately, security no longer seems to end at one's border, for the dangers can come from all directions at any time, and the harm caused can be virtually irreparable. The United States cannot necessarily afford the luxury of relying on the threat of punishment or regime removal to deter the use of WMD; chemical, biological, and nuclear weapons have taken the rungs out of the escalation

\footnotetext{
${ }^{27}$ Steven R. David, "Risky Business: Let Us Not Take a Chance on Proliferation," Security Studies vol. 4, no. 4 (summer 1995): 776.

${ }^{28}$ U.S. Government, Joint Resolution to Authorize the Use of United States Armed Forces Against Iraq, Office of the Press Secretary, 2 October 2002.
} 
ladder, creating a world in which the first break in the WMD taboo is likely to be catastrophic.

\section{Counterproliferation Options}

As is evident, basing deterrence almost exclusively on retaliatory measures is becoming increasingly problematic as weapons of mass destruction proliferate around the globe and into unpredictable hands. Despite the confidence demonstrated in Iraqi Freedom, the United States is likely to face ever-increasing constraints over participating in regional conflicts, possibly rendering it "self-deterred" in some circumstances. In response, U.S. strategy has begun to focus on reducing the expected costs of engaging rogue states, known in military circles as "counterproliferation." 29 Then Secretary of Defense Les Aspin initiated this policy course in 1993 when he chartered the Defense Counterproliferation Initiative, partly in response to the major inadequacies in U.S. WMD detection capabilities revealed by the 1990-91 Gulf War. ${ }^{30}$ The U.S. intelligence community was shocked at how badly it had underestimated the quantities and deployment of Iraqi CB, sparking the awareness of how much damage such weapons could have caused. Eventually the United States consolidated programs associated with the Counterproliferation Initiative into the Defense Threat Reduction Agency in 1998, which is now responsible for developing new technologies through what is known as the Counterproliferation Program Review Committee (CPRC). ${ }^{31}$ The CPRC's mission is to identify areas where the United States needs new capabilities and to conduct

\footnotetext{
${ }^{29}$ U.S. Government, National Security Strategy, 14.

${ }^{30}$ Mitchel B. Wallerstein, "The Origins and Evolution of the Defense Counterproliferation Initiative," in Countering the Proliferation and Use of Weapons of Mass Destruction, edited by Vincent J. Jodoin and Alan R. Van Tassel (New York: McGraw-Hill, 1998), 23.

${ }^{31}$ Barry R. Schneider, Future War and Counterproliferation: U.S. Military Responses to NBC

Proliferation Threats (Westport, CT: Praeger, 1999), 55; Stephen Younger, Hearing on the Defense Threat Reduction Agency before the Emerging Threats and Capabilities Subcommittee, Armed Services Committee, U.S. Senate, Washington D.C., 10 April 2002; Counterproliferation Program Review Committee, Report on Activities and Programs for Countering Proliferation and NBC Terrorism, Executive Summary (May 2002).
} 
demonstrations of advanced concepts such as micromechanics, stealth materials, and cognitive computer systems.

The basic objective of counterproliferation is to develop capabilities for protection and defense in order to provide some safeguards in the event that deterrence fails. $^{32}$ However, there is also an emphasis on actively defeating the effects of proliferation, which has led to the recent perception that counterproliferation is virtually synonymous with the Bush Doctrine and its focus on preemption. In reality, the U.S. counterproliferation strategy is based on several objectives including nonproliferation, active defense, passive defense/consequence management, and counterforce. While such measures will never eliminate the potential for a WMD attack, they are ways to manage risk and enable the United States to continue to support international stability in a confident manner. The remainder of this chapter will briefly examine the range of counterproliferation options under review and development.

Nonproliferation: The use of export controls to prevent potential adversaries from acquiring advanced weaponry has always been the most sensible first line of defense in U.S. counterproliferation efforts. During the Cold War, the United States created the Coordinating Committee for Multilateral Export Controls to deny sophisticated technology to the Soviet Union, and a veritable alphabet soup of arms control agencies and treaties are in place today to limit the spread of WMD, including the Missile Technology Control Regime (MTCR), the Nuclear Suppliers Group (NSG), and the Enhanced Proliferation Control Initiative (EPCI). ${ }^{33}$ Unfortunately, the intense secrecy of weapons programs and the difficulty in placing restrictions on dual-use items

\footnotetext{
${ }^{32}$ U.S. Department of Defense, Proliferation: Threat and Response (Washington D.C.: January 2001), 69; National Defense University, The Counterproliferation Imperative: Meeting Tomorrow's Challenges (Washington D.C.: November 2001), 2; William J. Perry, "Preparing for the Next Attack," Foreign Affairs vol. 80, no. 6 (November/December 2001): 33.

${ }^{33}$ U.S. Department of Defense, Threat and Response, 70-77.
} 
has made this effort a very modest success. ${ }^{34}$ Blocking equipment such as centrifuges or $\mathrm{x}$-ray machines can be extraordinarily politically sensitive given the humanitarian benefit of their legitimate medical use. Companies and governments, driven by a motivation for profit, often overlook the possible negative security effects of commercial sales and neglect to ensure that their products are being used for their intended purpose. ${ }^{35}$ Iraq in particular shocked the world with the degree to which it was able to quietly procure the precursors to its arsenal of WMD prior to the 1990-91 Gulf War, often directly from suppliers in the West. ${ }^{36}$ The Internet is also proving to be a useful tool for proliferators, prompting the Bush administration to withdraw scores of technical documents relating to $\mathrm{CB}$ weapon production from the web and draft a new information security policy. ${ }^{37}$

As the revelations surrounding Pakistan's nuclear salesmanship makes clear, nonproliferation measures on a solely domestic basis are likely to be futile. To secure and regulate foreign sources of nuclear fuel and technological expertise, the United States primarily relies on the Cooperative Threat Reduction Program. By finding new employment for former nuclear scientists and dismantling ageing nuclear forces, this initiative aims to stem the flow of hardware and scientific expertise from the former Soviet Union to prospective WMD clients. ${ }^{38}$ Parallel to this effort, the United States has made a major financial and political commitment to the G-8 Partnership Against the Spread of Weapons and Materials of Mass Destruction, which intends to raise over \$20

\footnotetext{
${ }^{34}$ David Albright, "A Proliferation Primer," The Bulletin of Atomic Scientists vol. 49, no. 5 (June 1993): 14. Dual-use items are goods developed for civilian purposes, but which can be used for military applications or to produce weapons. The difficulty in controlling dual-use items is highlighted by the recent example of Japan trying to restrict exports of its PlayStation 2 video game system because it could process high quality images quickly, a feature much in demand for advanced missile guidance systems. See Morgan, Deterrence Now, 234.

${ }^{35}$ U.S. General Accounting Office, Post-Shipment Verification Provides Limited Assurance That Dual-Use Items Are Being Properly Used, GAO-04-357 (Washington D.C.: January 2004).

${ }^{36}$ Kenneth R. Timmerman, The Death Lobby: How the West Armed Iraq (London: Fourth Estate Limited, 1992); David Kay, "Denial and Deception Practices of WMD Proliferators: Iraq and Beyond," The Washington Quarterly vol. 18, no. 1 (winter 1995): 85-105; Chandler, Tomorrow's War, Today's Decisions, 129 and 154.

${ }^{37}$ William J. Broad, "U.S. Tightening Rules on Keeping Scientific Secrets," New York Times, 17 February 2002.

${ }^{38}$ Michael Krepon, “Moving Away from MAD," Survival vol. 43, no. 2 (summer 2001): 87.
} 
billion in ten years to help maintain control over this dismantlement process. As important as this program is, it fails to address the equal danger of black market trade in atomic technology among second-tier nuclear states like Pakistan. Libya's rapid progress in assembling the basic components to enrich uranium was a harsh reminder that even intense monitoring can fail to detect secret nuclear development programs. ${ }^{39}$ In order to target the transport of WMD materials, the United States is touting a multilateral effort called the Proliferation Security Initiative (PSI). Announced in May of 2003, the PSI intends to utilize consensus among its members to provide international backing for the seizure of suspected arms shipments between proliferators and rogue states. ${ }^{40}$ While significant obstacles involving maritime law could hamper this cooperative system, the increasing success of multilateral policing operations (as demonstrated by the apprehension of several dangerous international terrorists) ${ }^{41}$ provides some grounds for hope. Interdiction missions will inevitably lead to tense confrontations and probably some embarrassing mistakes, but at the very least the PSI should put proliferators on notice of an increased risk of getting caught sending WMD to unsavory buyers.

One troubling aspect of nonproliferation efforts is that many states see them as hypocritical because the enforcing nations do not always adhere to agreements or are exempt from them, thereby seeming to be "advocating water, but drinking wine."42 While there is little doubt that documents such as the NPT enshrine a double-standard of nuclear possession, this is an unfortunate but inevitable reality given the impracticalities

\footnotetext{
${ }^{39}$ Douglas Frantz, "Libya's Arms Development Surprises U.N.," Los Angeles Times, 21 February 2004.

${ }^{40}$ For instance, the PSI would ideally prevent a repetition of the botched search of a North Korean boat carrying Scud missiles bound for Yemen in December of 2002. See Thomas E. Ricks and Peter Slevin, "Spain, U.S. Seize N. Korean Missiles," Washington Post, 11 December 2002; Nicholas Kralev, "U.S. Asks Aid Barring Arms From Rogue States," Washington Times, 5 June 2003; Bradley Graham, "Gaps in Plan to Halt Arms Trade," Washington Post, 3 August 2003.

${ }^{41}$ Sarah Lyall, "Arrest of Terror Suspects in London Turns up a Deadly Toxin," New York Times, 8 January 2003; Toni Locy and Kevin Johnson, "Suspect Helping U.S. Gauge Al-Qaeda's Arsenal," USA Today, 15 January 2003; Don Van Natta Jr., "Al Qaeda Hobbled by Latest Arrest, U.S. Says," New York Times, 3 March 2003.

${ }^{42}$ Steve Fetter, "What is the Threat?" in The Use of Force: Military Power and International Relations, edited by Robert J. Art and Kenneth N. Waltz, $5^{\text {th }}$ edition, (Maryland: Rowland \& Littlefield), 355.
} 
of verification and the danger of noncompliance. Overall, it is better to limit whatever further proliferation may take place, recognizing that any effective arms control measures means fewer weapons that may be used in any circumstance. To avoid excessive accusations of exceptionalism, it is important for the United States to act on a multilateral basis whenever possible in resolving international disputes and to serve as a role model when considering proposals like the Comprehensive Test Ban Treaty, conventions against CB weapons, or disarmament initiatives. In sum, nonproliferation efforts may have significant shortcomings, but they are among the brightest prospects for multinational cooperation and are likely to be the most cost-effective means to reduce the threat posed by WMD.

Active Defense: Given the enormous challenges inherent in nonproliferation, U.S. government officials are giving much more attention and funding to missile defense programs. ${ }^{43}$ Often maligned as a pipe dream that seeks to "hit a bullet with a bullet," some observers feel that the low reliability of such a system, combined with its susceptibility to countermeasures, means that it is unlikely to provide many strategic benefits. $^{44}$ Referring to the current National Missile Defense (NMD) proposal, one group of analysts assert: "Confidence in the effectiveness of the planned NMD system would not be high enough to increase U.S. freedom of action beyond the level already achieved through deterrence." ${ }^{45}$ In this view, even if the chance of a missile defeating the NMD system and destroying a city were incredibly small, it would still generate

\footnotetext{
${ }^{43}$ James Dao, "Pentagon Optimistic About Missile Shield," New York Times, 15 April 2002; Greg Miller, "U.S. Claims 90\% Hit Rate in Missile Plan," Los Angeles Times, 19 March 2003.

${ }^{44}$ William J. Broad, "The Nuclear Shield: Repelling an Attack," New York Times, 30 June 2000; Richard L. Garwin, "A Defense That Will Not Defend," The Washington Quarterly vol. 23, no. 3 (summer 2000): 110; Gordon R. Mitchell, Strategic Deception: Rhetoric, Science, and Politics in Missile Defense Advocacy (East Lansing, MI: Michigan State University Press, 2000); William J. Broad, "Achilles' Heel in Missile Plan: Crude Weapons," New York Times, 27 August 2001; Bradley Graham, "Scientists Raise Doubts About Missile Defense," Washington Post, 16 July 2003; Paul Richter, "Missile Defense System Doubts," Los Angeles Times, 22 January 2004.

${ }^{45}$ George Lewis, Lisbeth Gronlund, and David Wright, "National Missile Defense: An Indefensible System," Foreign Policy no. 117 (winter 1999-2000): 128.
} 
extreme caution in U.S. foreign policy. Conversely, Robert Powell, an expert on nuclear deterrence theory, believes that a moderately effective NMD will decrease American security by making the United States more bold in its interactions with rogue states, thereby increasing the risk of a nuclear attack in response. ${ }^{46}$ Other critics point out that if American NMD ambitions are too extensive or seen as too effective, Russia and China may respond with a missile build-up of their own, possibly producing an overall net loss in security. In order to avoid a strategic arms race among the great powers over the balance of offensive and defensive capabilities, there has been extensive dialogue over how to defend against the threats posed by rogue states without undermining the supposedly desirable situation of MAD, perhaps involving the unlikely partnership of the two former Cold War rivals cooperating over the development of missile defense systems. $^{47}$

On the opposing side of this debate are those who feel that any uncertainty over accuracy will affect the enemy as well, and it is worth "raising the admission price" of potential WMD attacks as high as possible. ${ }^{48}$ According to this position, U.S. missile defenses could act as a "psychological deterrent," providing important insurance against attack by raising the prospect in an adversary's mind that using its WMD-missile force could bring about all of the costs inherent in U.S. retaliation without any of the "benefit" of causing damage to American interests. ${ }^{49}$ As Lindsay and O'Hanlon put it, “...even a

\footnotetext{
${ }^{46}$ Robert Powell, "Nuclear Deterrence Theory, Nuclear Proliferation, and National Missile Defense," International Security vol. 27, no. 4 (spring 2003): 88.

${ }^{47}$ Erik Eckholm, "Experts Try to Make Missile Shield Plan Palatable to China," New York Times, 28 January 2001; Patrick E. Tyler, "Putin Invites West to Work on a Defense for Missiles," New York Times, 21 February 2001; David E. Sanger and Thom Shanker, "U.S. Plans Offer to Russia to End ABM Treaty Dispute," New York Times, 28 May 2001.

${ }^{48}$ Henry Kissinger, Does America Need a Foreign Policy? (New York: Simon \& Schuster, 2001), 69; U.S. Department of Defense, Nuclear Posture Review (Washington D.C.: 31 December 2001).

${ }^{49}$ Jerome H. Kahan, "Deterrence and Warfighting in an NBC Environment," in The Niche Threat: Deterring the Use of Chemical and Biological Weapons, ed. Stuart E. Johnson (Washington D.C.: National Defense University Press, 1997), 54; Stephen J. Hadley, "A Call to Deploy," The Washington Quarterly. vol. 23, no. 3 (summer 2000): 100; Philip Gordon, "Bush, Missile Defence and the Atlantic Alliance," Survival vol. 43, no. 1 (spring 2001): 18.
} 
porous missile defense could enhance deterrence by forcing an attacker with limited capability to contemplate the possibility that any attack would be futile and fatal.",50 With such a system in place, rogue states would be less inclined to engage in blackmail or extreme coercive measures under the cover of deterrence, realizing that the United States might feel secure enough to follow through regardless of whether the threat was a bluff or not. This viewpoint meshes with Robert Powell's central premise-that robust defensive capabilities would also make the U.S. willingness to use force offensively more credible-but concludes instead that greater freedom of action would not inherently be so dangerous and is therefore advantageous to American foreign policy. The prospect of such an outcome has resulted in much of the international opposition to WMD by those interested in keeping American military might as constrained as possible. $^{51}$

Both sides of the argument have merit, and ultimately the decision will come down to technical feasibility and what level of insurance against missile attack is worth the expense involved. In brinksmanship situations, if an adversary is hoping to deter the United States, will it likely rely heavily on a long-range missile threat? The sources of danger will multiply as cruise missile proliferate, weapons perfectly suited for carrying BW and capable of extreme accuracy if coupled with Global Positioning System (GPS) technology. ${ }^{52}$ Choosing defensive technologies against this panoply of threats will require careful prioritization, especially with research into boost-phase options and sophisticated theatre missile defense (TMD) technologies competing for budget

\footnotetext{
${ }^{50}$ James M. Lindsay and Michael E. O'Hanlon, Defending America: The Case for Limited National Missile Defense (Washington DC: Brookings Institution Press, 2001), 20.

${ }^{51}$ Robin Ranger and David Wiencek, The Devil's Brews II: Weapons of Mass Destruction and International Security, Bailrigg Memorandum 17 (Lancaster: Centre for Defence and International Security Studies, 1997), 49; Lodal, The Price of Dominance, 58-59.

${ }^{52}$ Kathleen C. Bailey, Doomsday Weapons in the Hands of Many: The Arms Control Challenge of the 90s (Chicago: University of Illinois Press, 1991), 103; Chandler, Tomorrow's War, Today's Decision, 178; Schneider, Future War and Counterproliferation, 126; Rex R. Kiziah, Assessment of the Emerging Biocruise Threat, Future Warfare Series No. 6 (Maxwell Air Force Base, AL: Air War College, August 2000).
} 
resources. Further complicating matters is the uncertainty and mistrust spurred by the revelation that the Patriot missile launcher's success in the 1990-91 Gulf War was a myth, sparking challenges of NMD and TMD performance and test results that continue to this day. ${ }^{53}$ All in all, there is a great deal of skepticism regarding missile defense systems, and much of it is justified. Nevertheless, the unique coercive power of ballistic and cruise missiles justifies further testing of new defensive technologies to see whether they are technically feasible and cost-effective.

Passive Defense/Consequence Management: Considering the fallibility of nonproliferation efforts and missile defenses, it is imperative to try and limit the destructiveness of WMD attacks should they ever occur. Given their smaller claim on resources relative to other counterproliferation missions, passive defenses can be justifiably described as offering "more 'anti-bang' for the buck." 54 Military gaming exercises show that CB detection and defense capabilities can significantly boost U.S. resolve, giving soldiers confidence that they can fight and win in a contaminated environment. ${ }^{55}$ Reversing perspective, war games in which teams were assigned to play the role of a regional adversary revealed that the U.S. ability to operate in a WMD environment had a major impact on the adversary's decision over whether to resort to unconventional weapons. ${ }^{56}$ Similar to the psychological deterrent power of missile defenses, effective passive defense measures are likely to create uncertainty in the mind of an adversary that their WMD use would succeed, causing them to fear inviting repercussions without any military gain.

\footnotetext{
${ }^{53}$ Rick Atkinson, Crusade: The Untold Story of the Gulf War (London: Harper Collins Publishers, 1994), 79; Bradley Graham, "Improved Air Defense Gets Tryout in Combat," Washington Post, 21 March 2003.

${ }^{54}$ Richard Betts, "Universal Deterrence or Conceptual Collapse? Liberal Pessimism and Utopian Realism," in Utgoff, The Coming Crisis, 79.

${ }^{55}$ Robert G. Joseph, "The Role of Nuclear Weapons in U.S. Deterrence Strategy," in Deterrence in the $21^{\text {st }}$ Century, ed. Max G. Manwaring (London: Frank Cass \& Co., Ltd., 2001), 58.

${ }^{56}$ Robert G. Joseph and John F. Reichart, "NBC Military Planning: Lessons Learned from Analysis and Wargaming," in Jodoin and Van Tassel, Countering the Proliferation and Use of Weapons of Mass Destruction, 185.
} 
To reinforce this perception, the Department of Defense (DoD) is developing and fielding a range of sensors, masks, decontamination systems, and medical kits for soldiers in combat. ${ }^{57}$ New protective suits and masks are standard issue for American soldiers, and DoD is adding vaccinations against smallpox to the other immunizations soldiers receive. ${ }^{58}$ The U.S. military is also gradually expanding its training for operations involving WMD, including the use of simulations, the construction of Humvees that protect against and detect $\mathrm{CB}$, the creation of special response teams and medical units, and the exploration of new doctrine and operational tactics to limit vulnerability. ${ }^{59}$ In general, stationary "fixed" sites will either require extra protection or mobility in order to survive the aforementioned growth in GPS-guided munitions and cruise missiles. While there are surely shortcomings in certain areas and significant room for improvement, assessments that coalition soldiers in Operation Iraqi Freedom were reasonably well prepared to withstand a chemical weapons attack reflected well on America's progress in CB defense capabilities. ${ }^{60}$

Such training, investment, and innovation should be mirrored on the domestic level to improve the skills and equipment of first-responders and Civil Support Teams in

\footnotetext{
${ }^{57}$ Edward M. Spiers, Weapons of Mass Destruction: Prospects for Proliferation (London: Macmillan Press Ltd., 2000), 134; U.S. Department of Defense, Threat and Response, 85-90; John Hendren, "Pentagon Battles Unknown Preparing for a Toxic War," Los Angeles Times, 29 September 2002; Teresa Riordan, "Plastic Pods for Biological Attacks," New York Times, 30 September 2002.

${ }^{58}$ Vicki Kemper, "Vaccine Program Going Well, Military Reports," Los Angeles Times, 14 February 2003; Matthew Cox and William Matthews, "The Best Protective Gear in the World?" Air Force Times, 24 February 2003.

${ }^{59}$ U.S. Department of Defense, Chemical and Biological Defense Program, Annual Report to Congress and Performance Plan (Washington D.C.: April 2003); Ann Scott Tyson, "For Army, A New Primer in Chemical War," Christian Science Monitor, 21 October 2002; John Diedrich, "SpaceCom Improves Ability to Dodge Scuds," Colorado Springs Gazette, 31 January 2003; George Coryell, "New Humvee Protects Against All Chemical, Biological Warfare," Tampa Tribute, 11 March 2003. One particularly interesting project involves a competition sponsored by the Defense Advanced Research Projects Agency that set a $\$ 1$ million reward for a team that can construct an unmanned land vehicle capable of navigating across 200 miles of open desert without any human assistance. See Rene Sanchez, "Robot Race is Giant Step for Unmanned Kind," Washington Post, 10 March 2004.

${ }^{60}$ Matt Kelley, "Iraq Can Make Chemical Weapons That Penetrate U.S. Protective Gear," Associated Press, 17 November 2002; Peter Baker, "But What if the Iraqis Strike First?" Washington Post, 23 January 2003; Romesh Ratnesar, "Can They Strike Back?" Time, 3 February 2003; Tony Capaccio, "Iraq Probably Can't Mount Major Chemical Attack, General Says," Bloomberg.com, 4 March 2003.
} 
major cities. ${ }^{61}$ Especially after the U.S. anthrax attacks in the autumn of 2001 and subsequent reports of a plot to detonate a "dirty bomb" in a U.S. city, the threat of WMD has without question become a domestic concern. Border security is taking on critical importance, particularly in light of a new intelligence estimate that concludes that a WMD terrorist attack from ships, trucks or airplanes is more likely than a strike by longrange missiles. ${ }^{62}$ Thankfully this task is being substantially aided by the development of portable pager-sized nuclear detection devices that can sense minute amounts of radioactive material. ${ }^{63}$ Unfortunately, producing comparable biological weapon detectors is proving much more of a challenge, prompting research into advanced technologies such as tissue-based biosensors as well as specialized environmental and public health monitoring systems to improve detection speed and sensitivity. ${ }^{64}$

On the surface, it seems that the Bush Administration understands the need for developing such defensive technologies, having requested $\$ 11$ billion over two years to protect the nation against bioterror. ${ }^{65}$ Beyond the well-publicized smallpox vaccine shots prior to Operation Iraqi Freedom, Bush also proposed a $\$ 6$ billion program called Project Bioshield that would encourage private firms to conduct research into new vaccines against threats such as anthrax and experiment with novel techniques like artificial antibodies to potentially treat smallpox after infection. Some studies, however, have found that the Bush administration's current Homeland Security program is far too

\footnotetext{
${ }^{61}$ See Richard A. Falkenrath, Robert D. Newman, and Bradley A. Thayer, America's Achilles' Heel: Nuclear, Biological, and Chemical Terrorism and Covert Attack (Cambridge, MA: MIT Press, 1998); Bill Miller, "Denver Stages Mock Terror Attack," Washington Post, 23 February 2002.

${ }^{62}$ Walter Pincus, "U.S. Alters Estimate of Threats," Washington Post, 11 January 2002; Philip Shenon, "U.S. Widens Checks at Foreign Ports," New York Times, 12 June 2003.

${ }^{63}$ Barton Gellman, "Fears Prompt U.S. to Beef Up Nuclear Terror Detection," Washington Post, 3 March 2002; Steven Johnson, "Stopping Loose Nukes," Wired vol. 10, no. 11 (November 2002), Available online at http://www.wired.com/wired/archive/10.11/nukes.html; Anthony L. Kimery, "Searching for 'Dirty Bombs,"” Insight Magazine, 21 January 2003; Joby Warrick, "Bush to Seek Funds for Fighting 'Dirty Bombs," Washington Post, 30 January 2003; Philip Shenon, "Border Inspectors to Look for Radioactive Material," New York Times, 1 March 2003.

${ }^{64}$ U.S. Department of Defense, Threat and Response, 119; Judith Miller, "U.S. is Deploying a Monitor System for Germ Attacks," New York Times, 22 January 2003; Spencer S. Hsu, "Sensors May Track Terror's Fallout," Washington Post, 2 June 2003.

${ }^{65}$ Judith Miller, "Bush to Request Big Spending Push on Bioterrorism," New York Times, 4 February 2002.
} 
shallow to afford genuine protection and leaves many areas, especially critical industries like food supplies and oil refineries, dangerously unprepared against a catastrophic terrorist attack. ${ }^{66}$ Despite the considerable financial burden, it is important to have sufficient investment in these areas to protect both soldiers in the field and civilians at home, providing some level of safety if the unthinkable does occur.

Counterforce: Fearing that none of these largely defensive measures will be adequate, military analysts and government officials are more seriously considering the prospect of preemptive strikes against WMD facilities-eliminating them before they can be used or threatened in wartime. ${ }^{67}$ This new strategic outlook was articulated in an article by Secretary of Defense Donald Rumsfeld: "It is not possible to defend against every threat, in every place, at every conceivable time. Defending against terrorism and other emerging threats requires that we take the war to the enemy."68 The challenge, though, will be how to make this offensive outlook militarily successful and politically viable, given that "we can expect future WMD target sets to be large, extremely difficult to find, hardened, well-protected, and located next to things or people we do not want to damage or injure."69 Novel tunneling techniques have given rogue states the ability to bury bunkers and compartments, reinforced to withstand intensive bombing, far beneath the Earth's surface; indeed, there are now more than 1,100 such facilities known be in

\footnotetext{
${ }^{66} \mathrm{Jim}$ A. Davis and Barry R. Schneider, eds., The Gathering Biological Warfare Storm (Maxwell Air Force Base, AL: USAF Counterproliferation Center, April 2002); Gary Hart and Warren B. Rudman, CoChairs of Council on Foreign Relations Task Force, America Still Unprepared-America Still in Danger, 17 October 2002; Stephen Smith, "U.S. Farms Called Vulnerable to Terrorism," Boston Globe, 22 November 2002; Brad Knickerbocker, "Risk of Terrorism to Nation's Food Supply," Christian Science Monitor, 24 December 2002; Ceci Connolly, "Readiness for Chemical Attack Criticized," Washington Post, 4 June 2003.

${ }^{67}$ Wilkening, Ballistic-Missile Defence and Strategic Stability, 7; Michael J. Glennon, "Preempting Terrorism: The Case for Anticipatory Self-Defense," The Weekly Standard vol. 7, no. 19 (28 January 2002); U.S. Government, National Security Strategy, 15.

${ }^{68}$ Donald H. Rumsfeld, "Transforming the Military," Foreign Affairs vol. 81, no. 3 (May/June 2002): 2032.

${ }^{69}$ Chandler, Tomorrow's War, Today's Decisions, 156. See also Marc Dean Millot, "Facing the Emerging Reality of Regional Nuclear Adversaries," The Washington Quarterly vol. 17, no. 3 (summer 1994): 48.
} 
existence. $^{70}$ To be fair, advances have taken place on the detection side as wellincluding sophisticated techniques such as hyperspectral imaging, seismic sensing, and gravimetry-that help discover even well-hidden underground construction efforts. Still, if there are too many targets to be able to place confidence in even the most thorough of air campaigns to destroy them all, then a preemptive attack runs the risk of provoking the very attack it intended to foreclose. The reliability of target identification ought to be tempered by the experience of the 1990-91 Gulf War, after which target planners were shocked at how badly they underestimated the number of Iraqi WMD facilities. ${ }^{71}$ Conversely, the apparent overestimation of Iraqi WMD stockpiles during Iraqi Freedom also does little to instill faith in the ability of the intelligence community to develop an accurate target set. ${ }^{72}$

Even if it were possible to identify all of a state's underground facilities and WMD caches, there is significant disagreement over whether current conventional munitions are capable of destroying them. In order to be certain of reaching deeply buried targets, the DoD is reconsidering the employment of tactical nuclear weapons, and the U.S. Senate has cleared the way by lifting a ban on their research and development. $^{73}$ Some analysts argue that only nuclear weapons are powerful enough to

\footnotetext{
${ }^{70}$ Eric M. Sepp, Deeply Buried Facilities: Implications for Military Operations, Occasional Paper No. 14 (Maxwell Air Force Base, AL: Air War College, May 2000), 5; U.S. Department of Defense, Nuclear Posture Review; Michael A. Levi, Fire in the Hole: Nuclear and Non-Nuclear Options for Counterproliferation, Working Paper No. 31 (Washington D.C.: Carnegie Endowment, November 2002), 8; David A. Fulghum, "Iraq's Hidden Weapon 'Are Likely Underground," Aviation Week \& Space Technology, 16 December 2002.

${ }^{71}$ Chandler, Tomorrow's War, Today's Decisions, 154; Schneider, Future War and Counterproliferation, 155; Andrew Cockburn and Patrick Cockburn, Out of the Ashes: The Resurrection of Saddam Hussein (London: Verso, 2000), 96; Buster Glosson, War with Iraq: Critical Lessons (Charlotte, NC: Glosson Family Foundation, 2003), 287.

${ }^{72}$ Walter Pincus, "U.S. Has Still Not Found Iraqi Arms," Washington Post, 26 April 2003; Barton Gellman, "Frustrated, U.S. Arms Team to Leave Iraq," Washington Post, 11 May 2003; Greg Miller, "Analysis of Iraqi Weapons 'Wrong,"' Los Angeles Times, 31 May 2003; Michael Duffy, "Weapons of Mass Disappearance," Time, 9 June 2003; Barton Gellman, "Iraq's Arsenal Was Only on Paper," Washington Post, 7 January 2004.

${ }^{73}$ Paul Richter, "U.S. Works up Plan for Using Nuclear Arms," Los Angeles Times, 9 March 2002; Walter Pincus, "U.S. Nuclear Arms Stance Modified by Policy Study," Washington Post, 23 March 2002; Walter Pincus, "U.S. Explores Developing Low-Yield Nuclear Weapons," Washington Post, 20 February 2003;
} 
penetrate shielded and hardened facilities, and could have the added advantage of creating temperatures likely to incinerate any CB materials that are contained therein. ${ }^{74}$ Furthermore, advocates of tactical nuclear weapons believe that by being "usable" and thereby more credibly threatened, they will contribute to deterrence more than thermonuclear devices that would create unacceptable levels of damage. ${ }^{75}$ However, there is a growing consensus that such a strategy will fall prey to the same flaws that have foiled plans for tactical nuclear weapons before, from nuclear artillery to neutron bombs: no matter how tiny, they simply cannot be used without causing intolerable radioactive fallout. ${ }^{76}$ As an alternative, development is proceeding on new conventional options such as penetrating "thermobaric" bombs (called BLU-118Bs), advanced munitions that can repeatedly strike the same precise location to drive further and further down, and bombs that employ a "hard target smart fuze" to delay detonation until deep underground. ${ }^{77}$

Regardless how the debate over tactical nuclear weapons turns out, there is still the serious danger of causing collateral damage in the attempt to destroy WMD stockpiles. During Operation Desert Fox in 1998, then Secretary of Defense William

Dan Stober, "Nuclear 'Bunker Busters' Sought," San Jose Mercury News, 23 April 2003; Carl Hulse, "Senate Votes to Lift Ban on Producing Nuclear Arms," New York Times, 21 May 2003; William J. Broad, "Facing a Second Nuclear Age," New York Times, 3 August 2003; Julian Coman, "Pentagon Wants 'MiniNukes' to Fight Terrorists," London Sunday Telegraph, 26 October 2003.

${ }^{74}$ Thomas M. Dowler and Joseph S. Howard II, "Stability in a Proliferated World," Strategic Review vol. XXIII, no. 2 (spring 1995): 28; Walter Pincus, "Nuclear Strike on Bunkers Assessed," Washington Post, 20 December 2001; Levi, Fire in the Hole, 22.

${ }^{75}$ David G. Savage, "Nuclear Plan Meant to Deter," Los Angeles Times, 11 March 2002; Amy Scott Tyson, "Nuclear Plan Changes Calculus of Deterrence," The Christian Science Monitor, 14 March 2002; Richard T. Cooper, "Making Nuclear Bombs 'Usable," Los Angeles Times, 3 February 2003.

${ }^{76}$ Robert W. Nelson, "Low-Yield Earth-Penetrating Nuclear Weapons," Journal of the Federation of American Scientists vol. 54, no. 1 (January/February 2001): 1-5; William J. Broad, "Call for New Breed of Nuclear Arms Faces Hurdles," New York Times, 11 March 2002; Rose Gottemoeller, "On Nukes, We Need to Talk," Washington Post, 2 April 2002; Michael M. May and Zachary Haldeman, Effectiveness of Nuclear Weapons Against Buried Biological Agents (Stanford, CA: Center for International Security and Cooperation, June 2003).

${ }^{77}$ Andrew Koch, "Dual Delivery is Key to Buried Targets," Jane's Defence Weekly vol. 33, issue 10 (8 March 2000); U.S. Department of Defense, Threat and Response, 90; National Defense University, The Counterproliferation Imperative, 30; Andre C. Revkin, "Advanced Armaments," New York Times, 3 December 2001; John F. Burns, with Eric Schmitt, "U.S. Forces Join Big Assault on Afghan Stronghold," New York Times, 3 March 2002; Levi, Fire in the Hole, 17-20; Walter Pincus, "Future of U.S. Nuclear Arsenal Debated," Washington Post, 4 May 2003. 
Cohen left many Iraqi CB facilities off the target list, remarking: "We're not going to take a chance and try to target any facility that would release any kind of horrific damage to innocent people."78 This is a significant lesson for any rogue state hoping to secure sanctuary for its WMD. As a result, extensive research is underway on technologies like high-power microwave weapons (that would disable the electricity and communications of a facility), high-temperature incendiaries (that would seek to burn up any released material) and special foam (that would seal off a site and render it unusable without releasing its contents) to disable a target without emitting WMD. ${ }^{79}$ Given that even the most protected underground sites require contact with the surface, the prospects for "functional defeat," or isolating a facility by destroying its electronics or support systems, are rather promising. ${ }^{80}$

Finally, probably the most difficult counterforce mission involves hunting down mobile ballistic and cruise missile launchers. In fact, during the 1990-91 Gulf War there was not a single confirmed kill of a mobile Scud launcher, though the immense number of operations against them did have some beneficial effect by forcing Scud teams to fire quickly and move continuously, thereby reducing the pace of launches. ${ }^{81}$ In order to rectify this shortcoming, the DoD is now employing advanced unmanned aerial vehicles (UAVs) and new hyper-spectral imaging satellites that will be capable of dwelling onsite or achieving rapid enough revisit rates to enable persistent surveillance. ${ }^{82}$ With more

\footnotetext{
${ }^{78}$ Steven Lee Myers, "The Targets: Jets Said to Avoid Poison Gas Sites," New York Times, 18 December 1998.

${ }^{79}$ Bryan Bender, "USA Planning Warhead to Hit CB Weapons," Jane's Defence Weekly, 24 March 1999; John Hendren, "U.S. Studies Foam Bombs Among Options to Isolate Chemicals," Los Angeles Times, 18 July 2002; David A. Fulghum, "Microwave Weapons May Be Ready for Iraq," Aviation Week \& Space Technology, 5 August 2002; Michael Smith, "Saddam to be Target of Britain's 'E-Bomb," London Daily' Telegraph, 26 August 2002; Michael Sirak, "US Air Force Set to Acquire Chem-Bio 'Agent Defeat' Weapons Soon," Jane's Defence Weekly, 4 December 2002.

${ }^{80}$ Sepp, Deeply Buried Facilities, 10, and 23-28; Levi, Fire in the Hole, 21.

${ }^{81}$ Chandler, Tomorrow's War, Today's Decisions, 111; Schneider, Future War and Counterproliferation, 127.

${ }^{82}$ U.S. Department of Defense, Nuclear Posture Review; Vernon Loeb, "U.S. Gains in Attacking Mobile Arms," Washington Post, 5 July 2002; Eric Schmitt, "U.S. Would Use Drones to Attack Iraqi Targets,"
} 
accurate and versatile sensors (like J-STARS and AWACS), the development of improved data fusion capabilities should produce near-real-time intelligence that will enhance counter-missile operations. ${ }^{83}$ Also, as with the underground bunkers, information warfare options that aim at the functional defeat of missile launches either by disrupting orders to fire or confusing missile guidance systems may be an effective strategy. $^{84}$

Despite the admirable progress in counterforce technologies, it is unclear who will win this offense/defense cat-and-mouse game over the long-term. Overall, the viability of deterrence turns on this evolution of strategy and the success of counterproliferation; if such measures are seen as effective then adversaries will be less likely to run the risk of using WMD and may not even bother to develop such weapons in the first place. On the other hand, if they are deemed a failure, rogue states may be emboldened to make challenges to international security, confident that the United States and its allies will find the dangers of a response too great and end up self-deterred. The difficult question is whether it is worth risking a war to eliminate a potential threat before it becomes truly imminent. There are no easy answers, and ultimately U.S. policymakers will have to make a careful balance of the costs of action versus inaction; as one observer put it: "Is it worth the price of another war to deny North Korea the atomic bomb?"85 Most likely not, but the Bush Administration has made it very clear that it will consider preventive force as an option, if only of last resort. This aspect of counterproliferation,

\footnotetext{
New York Times, 6 November 2002; Jonathan Finer, "A High-Tech Pilot Who Keeps His Feet on the Ground," Washington Post, 7 March 2003.

${ }^{83}$ Chandler, Tomorrow's War, Today's Decisions, 127; Greg Jaffe, "Iraq's Scuds Still Keep the Pentagon Guessing," Wall Street Journal, 15 October 2002; Ann Roosevelt, "New Systems Could Improve 'Next Great Scud Hunt,"” Defense Week, 25 November 2002; Mark Thompson, "The Great Scud Hunt," Time, 23 December 2002.

${ }^{84}$ Robert D. Critchlow, "Whom the Gods Would Destroy: An Information Warfare Alternative for Deterrence and Compellence," Naval War College Review vol. LIII, no. 3 (summer 2000): 32.

${ }^{85}$ Barry R. Schneider, Radical Responses to Radical Regimes: Evaluating Preemptive Counterproliferation, McNair Paper No. 41 (Washington D.C.: National Defense University Press, May 1995 ), 33.
} 
known as the Bush Doctrine, deserves special attention and will be addressed in detail in the next chapter. 


\section{Chapter 5}

\section{Preemptive and Preventive War}

The U.S. National Security Strategy (NSS) states that America must identify and destroy security threats before they reach its borders, reserving a right of military preemption even in the absence of a direct attack. According to the NSS, while the decision to preempt may be necessitated by modern technology and new adversaries, its justification is not novel:

The United States has long maintained the option of preemptive actions to counter a sufficient threat to our national security. The greater the threat, the greater is the risk of inaction-and the more compelling the case for taking anticipatory action to defend ourselves....To forestall or prevent such hostile acts by our adversaries, the United States will, if necessary, act preemptively. ${ }^{1}$

National Security Advisor Condoleezza Rice affirmed this viewpoint in a speech to the Manhattan Institute in October of 2002, claiming: "There has never been a moral or legal requirement that a country wait to be attacked before it can address existential threats."2 This may be the case in principle, but the record of American historical practice suggests that there is little to no precedent for the United States ever engaging in a preemptive military attack, with the exception of the Spanish-American War and more recent conflicts like Iraqi Freedom. ${ }^{3}$ Instead, the United States has primarily reacted to acts of aggression or chosen to support its foreign policy interests by conducting covert operations that were neither major armed engagements nor justified by an immediate threat.

\footnotetext{
${ }^{1}$ U.S. Government, The National Security Strategy of the United States of America (Washington D.C.: September 2002), 15.

${ }^{2}$ Condoleezza Rice, Wriston Lecture to the Manhattan Institute, New York, 1 October 2002.

${ }^{3}$ Craig Gilbert, "Can U.S. Be First to Attack Enemy?" Milwaukee Journal Sentinel, 31 March 2002; Richard F. Grimmett, "U.S. Use of Preemptive Military Force," Congressional Research Service, 18 September 2002; Michael Duffy, "Does Might Make Right?" Time, 30 September 2002.
} 
To be precise, the concept articulated by the NSS-also known at the Bush Doctrine-relates to a military action more appropriately termed preventive war. By contrast, a preemptive action, in its traditional meaning, is based on incontrovertible evidence that an enemy attack is imminent, leading the targeted state to strike first in order to attain an advantage. ${ }^{4}$ As common sense would suggest, there can be little expectation for a state to wait and absorb the first blow when war is at hand. Especially when terrorists are involved, the international community is bound to defer to the better judgment of governments in taking the offensive to ensure that any plot is foiled before coming to fruition. The inherent danger with such a strategy, though, is that it is based on the supposition of intended harm, and thus could bring about a war that perhaps might have been averted through eleventh hour diplomacy or a last minute change of heart. There may be standards of imminence that truly do equate to actual attack, such as missiles en route, but generally preemption seeks to precede the initiation of conflict enough to gain a decisive edge. If two states share this same intent, a very unstable situation can develop with each side hoping to preempt the other's planned preemption.

Alternatively, preventive war is a response not to imminent danger, but to longterm threat. According to one useful definition: "Preventive war is based on the concept that war is inevitable, and that it is better to fight now while costs are low rather than later when the costs are high. It is a deliberate decision to begin a war....Preemption, by contrast, is nothing more than a quick draw." ${ }^{5}$ Lawrence Freedman provides a more colorful comparison: "Prevention is cold blooded; it intends to deal with a problem before it becomes a crisis, while preemption is a more desperate strategy employed in the

\footnotetext{
${ }^{4}$ Michele Flournoy, "Preemption in Peacetime, Crisis and War," Speech to the National Defense University Conference on Counterproliferation, Washington D.C., 17 May 2001; Jack S. Levy and Joseph R. Gochal, "Democracy and Preventive War: Israel and the 1956 Sinai Campaign," Security Studies vol. 11, no. 2 (winter 2001-02): 7.

5 James J. Wirtz and James A. Russell, "U.S. Policy on Preventive War and Preemption," The Nonproliferation Review vol. 10, no. 1 (spring 2003): 116.
} 
heat of crisis." The distinguishing factors of preventive war are a degree of premeditation and a threat that is prospective rather than immediate. Such a description, if loosely interpreted, could apply to most all conflicts, and Freedman cautions that-in the absence of a compelling cause-claims of preventive war can easily become a cover for aggressive war. ${ }^{7}$ Hegemonic powers fearful of rising rivals, neighboring states with undefined borders, or historical enemies on constant alert, all could use preventive war as a universal justification depending on one's interpretation of what constitutes an inevitable threat. This elasticity explains a great deal of the reluctance of weaker states in the international system to justify any principle of anticipatory self-defense, especially preventive in nature, fearful that it will grant the United States carte blanche to wage war with the slightest provocation or even based on mere suspicion. ${ }^{8}$

In truth, it is not readily apparent whether the Bush Administration makes a clear distinction between preemptive and preventive war, often using them interchangeably or in a similar context. Secretary of Defense Donald Rumsfeld gave a sweeping call to action in a speech to the graduating class of the Air Force Academy in May of 2002: "Prevention and preemption are the best, and indeed in most cases the only defense against terrorism. Our task is to find and destroy the enemy before they strike us. And it's a big world."9 A few months earlier, Paul Wolfowitz, Rumsfeld's Deputy, made similar remarks to a conference in Munich: "Our approach has to aim at prevention and not merely punishment. We are at war. Self-defense requires prevention and sometimes

\footnotetext{
${ }^{6}$ Lawrence Freedman, "Prevention, Not Preemption," The Washington Quarterly vol. 26, no. 2 (spring 2003): 107.

${ }^{7}$ Ibid., 108.

${ }^{8}$ Stanimir A. Alexandrov, Self-Defense Against the Use of Force in International Law (Cambridge, MA: Kluwer Law International, 1996), 149; Stephen Murdoch, "Preemptive War: Is It Legal?" The Washington Lawyer vol. 17, no. 5 (January 2003): 29.

${ }^{9}$ Donald H. Rumsfeld, Speech at the Air Force Commencement Ceremony, Colorado Springs, Colorado, 29 May 2002.
} 
preemption."10 In the aftermath of 11 September 2001 , one would expect the United States to make a vigorous effort to track down members of $\mathrm{Al}$ Qaeda. However, given that terrorists are scattered across the globe, including in the United States, a crucial issue left unanswered was what criteria or standard of threat would be used to trigger preemptive or preventive action, especially against states that lack a clear connection to Al Qaeda.

President Bush's speeches justifying Iraqi Freedom provide some clue as to how his administration interprets the Bush Doctrine. Just prior to the war, Bush described Iraq as a "direct and growing threat," adding that "Acting against the danger will also contribute greatly to the long-term safety and stability of our world." ${ }^{11}$ And yet, even putting the WMD controversy aside, there was never any evidence that Saddam Hussein was actively planning to attack the United States or its allies (either directly or through terrorists), the traditional criterion for a preemptive war. Bush chose to use the word "direct" rather than "imminent" apparently to highlight the perceived severe-but not proximate-nature of the Iraqi threat. In his 2003 State of the Union Address, Bush specifically denied the need to show proof of impending harm:

Some have said we must not act until the threat is imminent. Since when have terrorists and tyrants announced their intentions, politely putting us on notice before they strike? If this threat is permitted to fully and suddenly emerge, all actions, all words, and all recriminations would come too late. Trusting in the sanity and restraint of Saddam Hussein is not a strategy, and it is not an option. ${ }^{12}$

Without an indication of intentions or a fully emerged or imminent threat, it is clear that the Bush Doctrine moves beyond acts of anticipatory self-defense. Rather, it sanctions preventive war, basing security on the elimination of potential threat rather than the

\footnotetext{
${ }^{10}$ Paul Wolfowitz, Remarks at the $38^{\text {th }}$ Munich Conference on Security Policy, Munich, Germany, 2 February 2002.

${ }^{11}$ George W. Bush, Speech at the American Enterprise Institute, Washington D.C., 26 February 2003.

${ }^{12}$ George W. Bush, State of the Union Address, Washington D.C., 28 January 2003.
} 
power of deterrence. This is not to say that U.S. policy is necessarily misdirected, merely that it adheres less closely to a preemptive war strategy than its rhetoric might suggest. To be fair, the lines between the two concepts will never be clearly drawn, especially since the United States is unlikely to face a foe that telegraphs its intentions by carrying out a laborious mobilization. A calculation of imminent threat will rather be within the domain of the intelligence services, whose information is only as good as its sources. As such, especially if any other major attacks occur, the United States will likely shift toward preventive measures under the philosophy that without adequate warning it can only gain protection by taking the offensive. Already, some U.S. administration officials are discrediting the prospects for an effective defense against terrorists and rogue states, ${ }^{13}$ and several other European countries are incorporating the concept of preventive actions into their security strategies. ${ }^{14}$

There is clearly a great deal of controversy regarding the Bush Doctrine and its implications for international stability. The adoption of a preventive war policy is nothing short of revolutionary, and it remains to be seen whether it is a practical solution to today's security environment. In this chapter, I will first address the theoretical and legal underpinnings of preemptive and preventive war, employing historical examples as illustrations and analogies for current dilemmas. I will then examine how contemporary circumstances might alter our understanding of these concepts, requiring a redefinition of the basic terms and a reconsideration of some primary assumptions. Finally, I will show how this reformulation relates back to the discussion of deterrence and counterproliferation, and how it can inform U.S. strategy. I conclude that the Bush

\footnotetext{
${ }^{13}$ Condoleezza Rice, Remarks on Terrorism and Foreign Policy, Paul H. Nitze School of Advanced International Studies, Washington D.C., 29 April 2002; Richard Cheney, Speech at the Veterans of Foreign Wars $103^{\text {rd }}$ National Convention, Nashville, Tennessee, 26 August 2002.

${ }^{14}$ Elise Kissling, "Preemption an Option for EU," Frankfurter Allgemeine Zeitung, 30 May 2003; Francois Heisbourg, "A Work in Progress: The Bush Doctrine and Its Consequences," The Washington Quarterly vol. 26, no. 2 (spring 2003): 83.
} 
Doctrine is a modern iteration of a historic line of thought justifying anticipatory action, but one that lacks a foundation of articulated standards, however imprecise. Failure to provide any genuine restraints on an offensive notion of self-defense will likely generate a backlash among targeted states. Fearful that their security depends on a favorable American assessment of their peaceful intentions, many states will probably prefer to embrace WMD for deterrence instead, exacerbating the U.S. security dilemma.

\section{Preemptive War and Self-Defense}

A state's right to self-defense is clearly expressed in international law, both in treaty and in custom. ${ }^{15}$ Moreover, an allowance for responding to aggression is not necessarily limited to repelling invading troops, but can expand to include carrying out limited reprisals or an incursion into enemy territory to destroy the offending military force. ${ }^{16}$ For example, while disagreements may persist over the morality of the nuclear attacks at the conclusion of America's counter-offensive against Japan after Pearl Harbor, the basic justification for the war in the Pacific was sound. Likewise, there were few objections to Kuwait's effort to defend itself against the Iraqi invasion in 1990, even to the point of enlisting an international coalition that both evicted the aggressors and carried out an extensive bombing campaign in Iraq. The act of illegitimately initiating hostilities forfeits certain aspects of territorial immunity and empowers the attacked state to undertake defensive-as well as retaliatory-measures.

This retaliatory privilege has its bounds, though, as when the international community rejected U.S. claims to have exhausted all diplomatic options before

\footnotetext{
15 Anthony Clark Arend, "International Law and the Preemptive Use of Military Force," The Washington Quarterly vol. 26, no. 2 (spring 2003): 90.

${ }_{16}$ Myers S. McDougal and Florentino P. Feliciano, Law and Minimum World Order (New Haven, CT:

Yale University Press, 1961), 222-23.
} 
launching air strikes against Libya in $1986 .{ }^{17}$ Stunned by a string of terrorist atrocities linked to Libyan leader Muammar Gaddafi that culminated in the bombing of a disco in Berlin, the United States decided to send a message that such brutal attacks would have consequences. Similar recriminations of expediency and excessive force surround President Bill Clinton's 1998 selection of a reputed pharmaceutical plant in Sudan as the target of a cruise missile attack in response to the Al Qaeda bombings of two U.S. embassies in Africa. Ambiguous evidence connecting the plant to chemical weapons production or terrorist activity undermined claims of a defensively motivated reprisal, and amplified suspicions that a desire to deflect attention from Clinton's escalating personal scandal was at play. ${ }^{18}$ In the Libyan case, Reagan was careful not to identify the airstrikes as retaliation but rather a kind of preventive self-defense: "Gaddafi was supporting terrorist attacks against the U.S. He was also planning further attacks and there was no way of guarding effectively all the possible targets."19 The parallels between this quote and the Bush Doctrine are self-evident: invoking a war on terror, discounting a feasible defense, and claiming that preventive strikes are the only alternative.

Self-defense can also include anticipatory actions made prior to the initiation of hostilities by the aggressor. In the words of legal scholar Elihu Root: "International law does not require the threatened state to wait in using force until it is too late to protect itself." ${ }^{20}$ Sensible in principle, it has nevertheless proven difficult to reach a consensus

\footnotetext{
${ }^{17}$ Alexandrov, Self-Defense Against the Use of Force in International Law, 185. See also George J. Church, "Targeting Gaddafi," Time, 21 April 1986; Seymour Hersh, "Target Gaddafi: Reagan's Secret Plot," The London Times, 22 February 1987.

${ }^{18}$ Karl Vick, "U.S., Sudan Trade Claims on Factory," Washington Post, 25 August 1998; Steven Lee Myers and Tim Weiner, "After the Attack: The Chemicals," New York Times, 27 August 1998; Michael Barletta, "Chemical Weapons in the Sudan: Allegations and Evidence," Nonproliferation Review vol. VI, no. 1 (Fall 1998): 115-136.

${ }^{19}$ Quoted in Timothy L.H. McCormack, Self-Defense in International Law: The Israeli Raid on the Iraqi Nuclear Reactor (New York: St. Martin's Press, 1996), 230.

${ }^{20}$ Quoted in Barry R. Schneider, Future War and Counterproliferation: U.S. Military Responses to NBC Proliferation Threats (Westport, CT: Praeger, 1999), 163.
} 
over what kind of preemptive actions are legitimate in practice. Jurists at Nuremberg rejected the German defense counsel's claim that the Nazi invasion of the Soviet Union was intended to forestall a Soviet attack from the East. ${ }^{21}$ Perhaps this explanation lacked credibility since recourse to a claim of self-defense was already made in justifying the Nazi offensive against Norway, which hardly posed as great a threat (despite its potential role as a launching pad for British naval missions). ${ }^{22}$ In the Tokyo war crimes trials, Japanese defense lawyers sought to invoke a similar right of self-preservation to account for its military advances, positing that the sanctions imposed upon it were a form of aggression. $^{23}$ Clearly the right of self-defense requires a more sophisticated standard than perceived danger or economic harm. Otherwise, without some sense of boundaries, it is likely to excuse any and all wars, which are usually based in some part on mutual fear and suspicion.

The UN can provide a sense of international standards in such matters. Article 51 of the UN Charter states:

\begin{abstract}
Nothing in the present Charter shall impair the inherent right of individual or collective self-defense if an armed attack occurs against a Member of the United Nations, until the Security Council has taken measures necessary to maintain international peace and security. Measures taken by Members in the exercise of this right of self-defense shall be immediately reported to the Security Council and shall not in any way affect the authority and responsibility of the Security Council under the present Charter to take at any time such action as it deems necessary in order to maintain or restore international peace and security. ${ }^{24}$
\end{abstract}

Based on this passage, some international legal scholars dispute the existence of a right of preemption altogether, noting that force is valid only "if an armed attack occurs," and

\footnotetext{
${ }^{21}$ Ian Brownlie, International Law and the Use of Force By States (Oxford: Oxford University Press, 1963), 258.

${ }^{22}$ McCormack, Self-Defense in International Law, 255.

${ }^{23}$ Brownlie, International Law and the Use of Force By States, 253. Granted that the oil embargo posed a genuine threat to the island nation domestically, its greatest impact was felt by the Japanese military, dependent on the resource to fuel its plans for regional expansion.

${ }^{24}$ United Nations Charter, Article 51. Available at http://www.un.org/aboutun/charter/chapter7.htm.
} 
not before. ${ }^{25}$ Such a reading, known as a "restrictive" view of Article 51, would exclude all claims of potential threat, imminent or otherwise, justifying the use of military force. It would likewise nullify any attempt to use economic sanctions, shifting alliances, or unstable governments as grounds for war. "Restrictivist" thinkers also point to the prominent role Article 51 gives to the Security Council as further proof that the right of self-defense is meant to be limited in scope, a stopgap until the international community can act.

Opposing this perspective, those who subscribe to the so-called "permissive" view of Article 51 focus instead on the notion of an "inherent" right of self-defense. ${ }^{26}$ Whereas Article 51 may be the authoritative source of treaty-based international law, pre-existing rights under customary law can exist that empower states to use force prior to being the victim of armed aggression. Justification for this interpretation springs from the recognition that being forced to wait and absorb the first blow of combat confers an enormous advantage to a hard-hitting assailant. In the words of moral theorist Michael Walzer:

...aggression often begins without shots being fired or borders crossed. Both individuals and states can rightfully defend themselves against violence that is imminent but not actual; they can fire the first shots if they know themselves about to be attacked. ${ }^{27}$

Just as there might not be time to alert the police of a crime about to take place, a state may need to foil another's offensive plans before they can be put into action.

\footnotetext{
${ }^{25}$ Brownlie, International Law and the Use of Force By States, 275; Louis Henkin, How Nations Behave: Law and Foreign Policy, $2^{\text {nd }}$ Edition (New York: Columbia University Press, 1979), 141; National Defense University, Center for Counterproliferation Research, The Counterproliferation Imperative: Meeting Tomorrow's Challenges (Washington D.C.: November 2001), 52.

${ }^{26}$ Julius Stone, Aggression and World Order (London: Stevens \& Sons Limited, 1958), 44; Derek W. Bowett, Self-Defence in International Law (Manchester: The University Press, 1958), 185; Richard G. Maxon, "Nature's Eldest Law: A Survey of a Nation's Right to Act in Self-Defense," Parameters vol. XXV, no. 3 (autumn 1995): 55-68; Christine Gray, International Law and the Use of Force (Oxford: Oxford University Press, 2000), 86.

${ }^{27}$ Michael Walzer, Just and Unjust Wars (New York: BasicBooks, 1977), 74.
} 
How does this qualification square with Article 51's requirement that states only act in self-defense if an armed attack occurs? "Permissive" scholars note that Article 51 does not explicitly limit self-defense solely to reactive measures because it does not use the phrase "if and only if." 28 This phrasing decision theoretically leaves room for alternative interpretations of when the inherent right of self-defense might apply. Moreover, Article 2 (4) of the UN Charter states: "All members shall refrain in their international relations from the threat or use of force against the territorial integrity or political independence of any state...."29 This section creates an inherent tension with Article 51 because it forbids a state of affairs short of armed conflict (the threat of force), but omits any assignment of responsibility for dealing with such coercion. ${ }^{30}$ As such, especially because the Security Council cannot generally be expected to respond to all instances of conflict—much less threats short of war-states may need to step in and fill the breach if they are facing an imminent attack.

"Restrictivists" criticize this interpretation as merely semantic gymnastics that distort the "plain meaning" of Article 51, which appears to have the basic intention of restricting state autonomy to resort to the use of force in favor of adjudication by the Security Council. ${ }^{31}$ It may be true, as international law expert Derek Bowett reports, that the UN Charter's preparatory work indicates that the authors intended to safeguard the customary right to self-defense. ${ }^{32}$ However, the overarching intention to empower the Security Council is undeniable, as exemplified by the requirement that even states

\footnotetext{
${ }^{28}$ Myres S. McDougal, "The Soviet-Cuban Quarantine and Self-Defense," The American Journal of International Law vol. 57, no. 3 (July 1963): 600; Anthony Clark Arend and Robert J. Beck, International Law and the Use of Force: Beyond the UN Charter Paradigm (London: Routledge, 1993), 73; McCormack, Self-Defense in International Law, 148. In the International Court of Justice case of Nicaragua v. United States of America in 1986, Judge Schwebel made this point in his dissent. ${ }^{29}$ United Nations Charter, Article 2 (4). Available at http://www.un.org/aboutun/charter/chapter1.htm.

${ }^{30}$ Bowett. Self-Defence in International Law, 191; Michael J. Glennon, "The Fog of War: Self-Defense, Inherence, and Incoherence in Article 51 of the United Nations Charter," Harvard Journal of Law and Public Policy vol. 25. no. 2 (spring 2002): 546.

${ }^{31}$ McCormack, Self-Defense in International Law, 148.

${ }^{32}$ Bowett, Self-Defence in International Law, 188.
} 
legitimately responding to armed attack must report to the Council and should not affect its authority or responsibility. In this way, by seeking an exception to the rule, "permissive" thinkers may be identifying a loophole that will be difficult to regulate, enabling states to develop their own conception of what constitutes a threat of force. As Michael Glennon notes, such a position “...would render chimerical the armed attack requirement...because an attack would then begin not with bullets and bombs but with pencils and paper, possibly deployed months or even years before actual hostilities."33 Not only would preemptive attack be authorized, but so too would preventive war, negating the purpose of Article 51.

The historical touchstone legal scholars often use to justify a limited right of preemptive attack - as well as to delegitimize preventive war-is known as the Caroline case. As a brief background, in 1837 on the Niagara River along the American border, insurgents seeking the overthrow of the British government in Canada were using an American steamship (the Caroline) from U.S. territory to transport men and supplies. ${ }^{34}$ Deeming the ship of piratical character, British forces elected to forcibly board the ship, set it on fire, and send it over the Niagara Falls to ensure that it could no longer provide such support. This incident set off a flurry of correspondence between diplomatic offices; the British minister in Washington claimed that since the ordinary laws of the United States were not being enforced in restraining the ship, the Caroline had to be destroyed in the interests of self-preservation and self-defense. Incensed at what many perceived as an unprovoked destruction of American lives and property, the U.S. minister in London presented the British government with a demand for reparations. The dispute languished for nearly five years, until the trial of one of the British assailants led

\footnotetext{
${ }^{33}$ Glennon, "The Fog of War," 547

${ }^{34}$ Historical details drawn from R.Y. Jennings, "The Caroline and McLeod Cases," The American Journal of International Law vol. 32, no. 2 (April 1938): 82-99. See also http://www.danorr.com/webster/webster_ashburton_treaty.html and http://www.yale.edu/lawweb/avalon/diplomacy/britian/br-1842d.htm.
} 
Daniel Webster, then U.S. Secretary of State, to begin an exchange of letters with his British counterpart (Lord Ashburton) that eventually resulted in a treaty confirming the eastern border of both nations. After a debate over several particulars of the Caroline case, Webster penned his now famous remark that to make such an attack, there must be shown a "necessity of self-defense, instant, overwhelming, leaving no choice of means and no moment for deliberation." Lord Ashburton assured Webster that the British action met these criteria, as the Caroline was likely to remain moored until the very moment of attack and it was extremely unlikely that the United States would prevent its departure, making the danger a virtual certainty. Satisfied with the concurrence on principle, though not on substance, Webster agreed to put the matter to rest.

Daniel Webster's correspondence regarding the Caroline case resulted in two fundamental principles regulating the use of force under international law. First, the principle of necessity requires that the defending state must face a proximate and severe threat before it can act. ${ }^{35}$ Only a threat that is truly imminent, leaving not a "moment for deliberation," can be legitimately preempted; distant dangers that are merely possible or probable would not suffice. Further, the threat must be "overwhelming," serious enough to merit a military response, or even the most minor threat could be used as a pretext for war. Naturally the principle of necessity is imprecise, given the difficulty of determining when an attack is certain or unavoidable. However, it provides an important exception to the strict "armed attack" rule of Article 51, which appears to forbid preemptive attacks under any circumstances. Second, while not captured in Webster's famous quotation, the principle of proportionality demands that self-defense not be retaliatory or punitive, only sufficient to repel the attack and provide reasonable protection against future

\footnotetext{
${ }^{35}$ McCormack, Self-Defense in International Law, 263.
} 
occurrences. $^{36}$ It would be unacceptable for a state to cite a series of small raids as justification for major conflict, a charge leveled against Israel for its role in the 1956 war with Egypt. ${ }^{37}$

A different Israeli-Egyptian conflict, the Six-Day War of 1967, provides a useful illustration of an instance of preemption more widely perceived as legitimate. This time around, prior to the outbreak of hostilities, Egypt carried out a series of unilateral provocations that seriously escalated tensions with its neighbor. Nasser, the Egyptian president, decided to mass troops in the Sinai, expel the UN Emergency Force in place as peacekeepers, and impose a blockade of the Straits of Tiran that severely threatened Israeli shipping and as such was already identified as a casus belli by Israel. ${ }^{38}$ Considerable controversy remains as to whether Nasser seriously intended war, or if he was merely practicing brinksmanship at the goading of the radical leadership in Syria. Regardless, from Israel's perspective these actions amounted to a situation wherein it was as though an armed attack had already taken place. Dependent on a large pool of mobilized reservists, Israel could not afford to maintain a defensive stance counterbalancing Egypt's formation on the border for a long period of time. ${ }^{39}$ As such, Michael Walzer argues that Israel experienced a "just fear" legitimizing the exercise of anticipatory force. ${ }^{40}$ Especially given that Nasser had declared that if war came Egypt's goal would be the destruction of Israel, the criteria of a severe and proximate threat mandated by Webster's principle of necessity seem to be satisfied. Less certain is answering whether the devastating Six-Day War Israel launched was proportionate,

\footnotetext{
${ }^{36} \mathrm{McDougal}$ and Feliciano, Law and Minimum World Order, 243; Gray, International Law and the Use of Force, 106.

${ }^{37}$ Alexandrov, Self-Defense Against the Use of Force in International Law, 151.

${ }^{38}$ Edward Luttwak and Dan Horowitz, The Israeli Army (London: Penguin Books Ltd., 1975). 221.

${ }^{39}$ Ibid., 212.

${ }^{40}$ Walzer, Just and Unjust Wars, 84-85.
} 
given that it virtually destroyed the Egyptian air force and secured significant portions of territory in the region.

The concept of preemptive military action has a mixed heritage, seemingly forbidden by the UN Charter but sanctioned by precedent and the principle of selfdefense. Especially in this day and age, when weapons of mass destruction can cause instantaneous and devastating harm, following without exception the precepts of a document drafted to respond to the lurching mobilization of mass armies could be a bit anachronistic. As Derek Bowett argues, "No state can be expected to await an initial attack which, in the present state of armaments, may well destroy the state's capacity for further resistance and so jeopardize its very existence." ${ }^{41}$ And yet, how much patience should we demand? The lessons of the Caroline case are not as clear as they may first appear; the ship was not launching an imminent attack, but was transferring troops and supplies. There was certainly time for some deliberation, if not the use of alternate means such as demanding that the United States secure its borders. In sum, the justification of self-defense is unavoidably elastic, and the following section will explore attempts to expand its scope beyond that of anticipatory action.

\section{Preventive War}

Unlike the preceding analysis on preemptive conflicts, there has been little legal or moral debate over whether preventive war can be justified. Even permissive interpreters of the UN Charter have been reluctant to link the self-defense clause of Article 51 to preventive war, and few philosophical thinkers have put forward principles to guide when it might be suitable. Perhaps this is because of its ignoble historical record; under the pretense of avoiding a more terrible conflict in the future, some states

\footnotetext{
${ }^{41}$ Bowett, Self-Defence in International Law, 191-92.
} 
have wrought immeasurable suffering with reputedly defensively oriented wars. Historian A.J.P. Taylor observes in his 70-year history of European affairs: "Every war between Great Powers with which this book deals started as a preventive war, not as a war of conquest."42 Even the examples of the Nazi invasion of Norway and Japan's attack on Pearl Harbor are probably most accurately described as preventive wars, initiated without any true imminent threat from the opposing side. As mentioned in the previous chapter, there are also numerous political difficulties-collateral damage, insufficient intelligence, etc...-inherent in striking a state without provocation. Along with these considerations, many observers shy away from sanctioning any military action that lacks a clear and specific threat because it provides an open-ended rationale for war, invoking Michael Glennon's concern that culpability can come at the stage of pencils and paper rather than anything resembling armed attack.

Despite the limited theoretical and legal grounding, preventive war has remained a constant factor in international affairs, even in the decades after the time frame of A.J.P. Taylor's study. Several scholars deem Germany's decision to plunge into World War I as preventive in nature, borne of a calculation that there was a limited window of opportunity before Russia completed its railroad network during which it was much preferable to implement the Schlieffen Plan for a two-front conflict in Europe. ${ }^{43}$ In the years following World War II, there were several instances of American journalists, military commanders, and political officials advocating an atomic strike on the Soviet Union before it could respond in kind. ${ }^{44}$ These preventive considerations continued after the end of the U.S. nuclear monopoly, particularly when regional crises and conflicts

\footnotetext{
${ }^{42}$ A.J.P. Taylor, The Struggle for Mastery in Europe, 1848-1918 (Oxford: Oxford University Press, 1954), 166.

${ }^{43}$ Hew Strachan, The First World War, Volume One (Oxford: Oxford University Press, 2001), 62-63; Richard Betts, "Suicide From Fear of Death?" Foreign Affairs vol. 82, no. 1 (January/February 2003): 43.

${ }^{44}$ Russell D. Buhite and William Christopher Hamel, "War for Peace: The Question of an American Preventive War Against the Soviet Union, 1945-1955," Diplomatic History vol. 14, no. 3 (Summer 1990): $367-84$.
} 
(such as Berlin, Korea, Taiwan, and Vietnam) heated up to the extent of risking an expansion into a wider war. Nor was the United States alone in contemplating advance strikes on possible nuclear rivals; in the early 1960s the Soviet Union seriously considered a military attack on China's nascent nuclear program, even conferring with the United States over a cooperative effort. ${ }^{45}$ Lesser known examples include India discussing allowing Israel to attack Pakistan's nuclear facilities in the early 1980s, and Iraq's bombing of Iran's nuclear reactor in $1984 .^{46}$ Beyond atomic diplomacy, the United States also conducted preventive military operations on a smaller scale against countries like Nicaragua, Grenada and Panama, basing its justification partly on the future danger posed by such states to international peace and security. ${ }^{47}$ More recently, in 1996 then Secretary of Defense William Perry threatened a similar kind of intervention against Libya, asserting that it "will not be allowed to begin production" at a CW facility hidden in the desert. ${ }^{48}$

By far the most famous example of a preventive strike was Israel's destruction of Iraq's Osiraq nuclear reactor in June of 1981. Supplied by the French, Osiraq had survived a bombing raid by Iran in 1980 and was scheduled to "go hot" and begin producing plutonium shortly after the attack took place. ${ }^{49}$ In a sense, then, the Israeli

\footnotetext{
${ }^{45}$ William Burr and Jeffrey T. Richelson, "Whether to 'Strangle the Baby in the Cradle:' the United States and the Chinese Nuclear Program, 1960-64," International Security vol. 25, no. 3 (winter 2000-01): 54-55 and 68; Robert S. Litwak, "The New Calculus of Pre-emption," Survival vol. 44, no. 4 (winter 2002-03): 61 .

${ }^{46}$ Barry R. Schneider, Radical Responses to Radical Regimes: Evaluating Preemptive Counterproliferation, McNair Paper \#41 (Washington D.C.: National Defense University Press, May 1995), 8; Schneider, Future War and Counterproliferation, 154.

${ }^{47}$ Ann Devroy and Patrick E. Tyler, "Bush Launches Strike to Seize Noriega; Fighting Widespread in Panama City," Washington Post, 20 December 1989; Michael R. Gordon, "U.S. Troops Move in Panama in Effort to Seize Noriega; Gunfire is Heard in Capital," New York Times, 20 December 1989; Christine Gray, International Law and the Use of Force, 97.

${ }^{48}$ Brad Roberts, "NBC-Armed Rogues: Is There a Moral Case for Preemption?" in Close Calls: Intervention, Terrorism, Missile Defense, and 'Just War' Today, edited by Elliott Abrams (Washington D.C.: Ethics and Public Policy Center, 1998), 83; Raymond Tanter, Rogue Regimes: Terrorism and Proliferation (London: Macmillan Press Ltd., 1999), 175.

${ }^{49}$ Steve Weissman and Herbert Krosney, The Islamic Bomb: the Nuclear Threat to Israel and the Middle East (New York: Times Books, 1981), 4 and 7; Seymour M. Hersh, The Samson Option: Israel, America and the Bomb (London: Faber and Faber, 1991), 9.
} 
mission was preemptive since it targeted a suspect facility immediately before it became sheltered due to its radioactivity. Yet, the justification for the attack was not some imminent danger of Baghdad gaining access to fissile material, but the possibility that Iraq could eventually develop nuclear weapons that would pose a profound threat to Israel's existence. Israeli Prime Minister Menachem Begin saw the Osiraq bombing as "a supreme act of national self-defense," since in his mind if Saddam Hussein were armed with atomic weapons, he "would not have hesitated to drop them on Israel's cities and population centers." ${ }^{, 50}$ Given that Iraq's future use of a nuclear bomb was conjecture at best, the Osiraq operation was certainly more preventive than preemptive in nature.

In Israel's defense, there was little doubt based on the type of reactor and nuclear fuel Iraq sought from France that Hussein was interested in a military device and not a civilian program. ${ }^{51}$ Moreover, given the technical specifications of Osiraq, Iraq would have acquired the necessary fuel for atomic weapons from the reactor within 18 months of its activation. While hardly an "instant" threat leaving not a "moment for deliberation," the prospect of a nuclear neighbor hostile to its very existence was certainly close to qualifying as an overwhelming danger for Israel. The question, of course, is how likely Iraq was to act upon its prospective capability. Hussein's animosity and threatening rhetoric toward Israel was well documented, but it does not then follow that he would carry out an attack likely to be suicidal (due to Israel's assumed retaliatory capability) without considerable cause. As for Webster's criteria, whereas the principle of necessity might remain unclear, there is widespread agreement that Israel's strike in

\footnotetext{
${ }^{50}$ Quoted in Weissman and Krosney, The Islamic Bomb, 16. See also Shai Feldman, The Bombing of Osiraq-Revisited," International Security vol. 7, no. 2 (fall 1982): 122.

${ }^{51}$ Uri Shoham, "The Israeli Raid Upon the Iraqi Nuclear Reactor and the Right to Self-Defense," Military Law Review vol. 109 (summer 1985): 207; Shlomo Nakdimon, First Strike: The Exclusive Story of How Israel Foiled Iraq's Attempt to Get the Bomb (New York: Summit Books, 1987), 74; McCormack, SelfDefense in International Law, 48.
} 
June of 1981 was astounding for its surgical precision and therefore would likely satisfy the principle of proportionality.

World opinion rejected Israel's claims of self-defense, remarking that the Osiraq bombing was undoubtedly preventive in nature and so could not satisfy the requirements of Article 51. Many speakers at the Security Council deliberations invoked the Caroline case, arguing that while preemptive strikes could be permissible under the Charter framework (thereby supporting the stance of "permissive" theorists), the Israeli circumstance did not meet this high standard because there was no imminent threat. ${ }^{52}$ Even the United States initially criticized Israel, miffed that American equipment was used in the attack, but later announced that Israel had indeed acted in self-defense. ${ }^{53}$ The United States eventually reversed its position fully, coming to view the Osiraq bombing as a virtual textbook case in successful counterproliferation. In fact, Secretary of State Colin Powell recently remarked: "The Israelis did it in 1981. It was a clear preemptive military strike. Everyone now is quite pleased even though they got the devil criticized out of them at the time." ${ }^{54}$ Israel stood virtually alone in the face of a UN resolution condemning its action, arguing that a second Holocaust could not be permitted under any circumstances. In the words of then Israeli Defense Minister Ariel Sharon, now Prime Minister: "Israel cannot afford the introduction of the nuclear weapon. For us, it is not a question of a balance of terror but a question of survival. We shall therefore have to prevent such a threat at its inception." term utility of such a strike since it may have led the Iraqis to better hide and protect their weapons programs.

\footnotetext{
${ }^{52}$ Arend and Beck, International Law and the Use of Force, 78.

${ }^{53}$ Nakdimon, First Strike, 235; McCormack, Self-Defense in International Law, 34.

${ }^{54}$ Quoted in Glenn Kessler and Peter Slevin, "Preemptive Strikes Must Be Decisive, Powell Says," Washington Post, 15 June 2002.

${ }^{55}$ Quoted in Jed C. Snyder, “The Road to Osiraq: Baghdad's Quest for the Bomb," Middle East Journal vol. XXXVII (autumn 1983): 582.
} 
The language of Israel's justification of the Osiraq strike is remarkably similar to the U.S. National Security Strategy_reflecting a fundamental rejection of the reliability of deterrence and therefore a willingness to employ preventive force as necessary. In a way, the United States now views rogue state WMD the same way that Israel saw Iraqi nuclear weapons: as an existential threat too great to live under indefinitely. For Israel, the threshold for unacceptable danger was placed not at the level of imminent attack, nor the perception of aggressive plans, nor even the possession of nuclear weapons, but at their development - truly a remarkable step from the traditional standards of preemptive war.

\section{The Bounds of Preemptive and Preventive War}

As WMD, and $\mathrm{CB}$ in particular, proliferate around the world, designating the mere development of these weapons as sufficient to merit offensive military action may appear to be a recipe for perpetual conflict-an endless string of Osiraqs. Yet, since WMD are uniquely capable of causing such an astounding degree of harm, some states may not find it prudent to put faith in deterrence alone to ward off a surprise attack or dilute an effort at coercive diplomacy. After all, an adversary may never overtly demonstrate the intent to injure; it could try to evade identification altogether and merely sow fear and destruction through covert attacks. Weapons transfers might take place to terrorist groups who, even when clearly culpable, can be difficult to punish (as shown by the operations in Afghanistan against Al Qaeda). To attempt and accommodate such considerations, respected philosopher Michael Walzer put forward three criteria to justify a first strike: “...a manifest intent to injure, a degree of active preparation that makes that intent a positive danger, and a general situation in which waiting, or doing anything other 
than fighting, greatly magnifies the risk."56 Walzer's formula is similar in spirit to Webster's standard in the Caroline case by reaffirming the requirement of an imminent threat before taking action. However, Walzer elaborates on Webster in two major areas: first, by calling for a degree of proof concerning the intent to harm; and second, by demanding evidence of plans to back up such intent with credible means of action. Like the Caroline principles, this is a significant departure from the strictures of Article 51, proposing a standard for when force can be used prior to an armed attack. Keeping these competing conceptualizations in mind, this last section will analyze how self-defense is developing in response to novel threats.

Standards of an acceptable defensive threshold have certainly changed over time. Even prior to the Caroline incident, in 1823 James Monroe articulated his eponymous doctrine which held that the United States would consider any attempt by Europe to extend its political influence into the Western hemisphere as a threat to its security. As legal scholar Elihu Root observed:

The [Monroe] doctrine is not international law but it rests upon the right of selfprotection and that right is recognized by international law. The right is a necessary corollary of independent sovereignty. It is well understood that the exercise of the right of self-protection may and frequently does extend beyond the limits of the territorial jurisdiction of the state exercising it. ${ }^{57}$

The Cuban Missile Crisis demonstrated yet another redefinition of the bounds of selfdefense, as the United States refused to accept the introduction of nuclear weapons to a country so close to its borders. Interestingly, in its public justification for the eventual blockade, the United States never referred to the right of self-defense under Article 51, but cited a threat to regional security under the auspices of the Organization of American

\footnotetext{
${ }^{56}$ Walzer, Just and Unjust Wars, 81.

${ }^{57}$ Elihu Root, "The Real Monroe Doctrine," The American Journal of International Law' vol. 8, no. 3 (July 1914): 432.
} 
States and Article 52 of the UN Charter. ${ }^{58}$ In fact, some scholars would argue that

Cuba's acquisition of missiles was the more defensive action since they had just been the victim of a U.S. backed coup attempt and were woefully out-gunned militarily. ${ }^{59}$ In the subsequent UN deliberations, as would occur again in the debates over Osiraq, various delegations referenced the principle of necessity and its requirement of an imminent threat as the basis for opposing the blockade. ${ }^{60}$

From the American perspective, the Soviet missile shipment may not have been overtly aggressive, but neither was it entirely benign in its attempt to shift the global balance of power against the United States. Even without plans for a direct attack, such weapons carried a coercive potential not easily measured and certainly not accounted for under Article 51 or Webster's principles. President Kennedy revealed a shift in strategic thinking in his famous television and radio address at the height of the crisis:

We no longer live in a world where only the actual firing of weapons represents a sufficient challenge to a nation's security to constitute maximum peril. Nuclear weapons are so destructive and ballistic missiles so swift, that any substantially increased possibility of their use or any sudden change in their deployment may well be regarded as a definite threat to peace. ${ }^{61}$

Regardless of its validity at the time, this outlook has taken root and found new adherents in the Bush Administration, which seeks to adapt traditional notions of selfdefense-and imminent threat in particular-to contemporary circumstances. Whereas the Cuban Missile Crisis dealt with ballistic missiles that could not easily be defended against, the current panoply of threat involves weapons that are equally destructive but may offer even less warning and possibly no indication of their origin. President George

\footnotetext{
${ }^{58}$ McCormack, Self-Defense in International Law, 216.

${ }^{59}$ Quincy Wright, "The Cuban Quarantine," The American Journal of International Law vol. 57, no. 3 (July 1963): 551; Alexandrov, Self-Defense Against the Use of Force in International Law, 156 and 159.

${ }^{60}$ Arend and Beck, International Law and the Use of Force, 75.

${ }^{61}$ John F. Kennedy, Address to the Nation on the Soviet Arms Buildup in Cuba, The White House, Washington D.C., 22 October 1962. Available at http://www.jfklibrary.org/j102262.htm.
} 
Bush remarked: "Terrorists and terror states do not reveal these threats with fair notice, in formal declarations-and responding to such enemies only after they have struck first is not self-defense, it is suicide." ${ }^{, 62}$ Akin to the British perspective in the Caroline case, the Bush Administration believes that there are enemies plotting and gathering strength in secret, and that there will be no warning of their design until the moment of attack.

The critical judgment will be over where to draw the line in measuring the imminence and magnitude of a prospective threat. How elastic ought these terms to become? 11 September 2001 may have shown the devastating effects of coordinated and covert terror attacks, but it did not provide a clear and simple standard for how to respond. If we return to Walzer's three principles, terrorist organizations will generally be fair game for anticipatory attacks since they very often both intend and plan to cause harm, usually without warning. Rogue states, though, are likely to be much more ambiguous in their intentions, and equally opaque regarding specific plans or capabilities. For example, a great deal of uncertainty surrounds Iran's reputed harboring of Al Qaeda suspects and its ambitions for a nuclear program. ${ }^{63}$ Should either of these charges be grounds for an attack if they could somehow be proven? A U.S. poll taken nine months after 11 September 2001 found that four out of five Americans favored military action against a country that is planning to attack the United States or aiding terrorists who target Americans, and three out of four favored action against enemies that are developing WMD. ${ }^{64}$ This finding meshes with a realization that at some point in the future, either deterrence will fail against a regional adversary or a rogue state will transfer WMD to a terrorist client, and the United States will need a near perfect defense

\footnotetext{
${ }^{62}$ George W. Bush, Remarks by the President in Address to the Nation, The White House, Washington D.C., 17 March 2003.

${ }^{63}$ David Stout, "Bush Again Accuses Iran and Syria of Harboring Terrorists," New' York Times, 21 July 2003; Douglas Frantz, "Iran Closes in On Ability to Build a Nuclear Bomb," Los Angeles Times, 4 August 2003.

${ }^{64}$ Andrea Stone, “Americans in Survey Support First Strike,” USA Today, 26 June 2002.
} 
to prevent catastrophe. In effect, the specter of WMD presents the equivalent of the famous IRA threat made against Margaret Thatcher, but instead directed at an entire nation: "We only have to be lucky once. You will have to be lucky always."

The advent of U.S. conventional military superiority has spurred widespread clandestine WMD proliferation and thereby weakened the foundations of both Webster's and Walzer's criteria, undermining the notion that there will be plans to discover or the ability to preempt them if they are known. Unfortunately, there is an inverse relationship between how advanced a WMD program is-a well-developed program should be more likely to elicit proof of a concrete threat-and how vulnerable it will be to attack given the extra time and stronger inclination to protect it. ${ }^{65}$ As one analyst put it:

The problem is not so much that WMD can be used with little warning-attacks with conventional weapons have all too often achieved tactical surprise-but that surprise use could be decisive and that the capability can be so successfully concealed that preemption is operationally impossible even if warning were available. ${ }^{66}$

Similarly, as a program becomes more robust, it will also be more dangerous to attack due to the risk of retaliation. In a world where one cannot take the chance that WMD will be used, the line of self-defense must be drawn not at imminent use, but at development and possession (a line of thinking beginning to resemble the Israeli perspective toward the Osiraq reactor or the American stance against Iraq and now North Korea). As journalist Johanna McGeary perceptively remarked in the lead-up to Iraqi Freedom: "Bush is proposing a doctrine of pre-emption that claims the right and the duty to invade another country-not based on a clear and present danger but on what he sees as an equally clear and future danger." ${ }^{, 67}$ In essence, the moral standards proposed by

\footnotetext{
${ }^{65}$ Michele Flournoy and Vinca LaFleur, "Quick-Stick Doctrine," Washington Post, 18 June 2002.

${ }^{66}$ Walter B. Slocombe, "Force, Pre-emption and Legitimacy," Survival vol. 45, no. 1 (spring 2003): 125.

67 Johanna McGeary, "What Does Saddam Have?" Time, 16 September 2002.
} 
Walzer and others requiring proof of active planning and intent to harm are swept aside by the notion that capability equals culpability, and that possession is the same as use.

The Bush administration is quick to assure that the number of cases where anticipatory action would be justified will always be small, limited to instances when the threat is very grave and the risks of waiting unacceptable. ${ }^{68}$ Left unclear, though, is how the very uncertainty that makes anticipatory force necessary will not also obscure estimations of when a threat reaches a level that is too risky to tolerate. After all, some states may only seek WMD for defensive purposes, and so a distinction must be drawn between the motivation to acquire and the motivation to use such weapons. ${ }^{69}$ Otherwise, as legal scholar Louis Henkin sharply observes, "To say that whoever sets up 'offensive weapons' justifies pre-emptive use of force would justify unilateral force by everyone everywhere."70 In a sense, given that the American military has the most potent offensive weapons, this may be the implicit bargain the United States hopes to strike, building forces “...strong enough to dissuade potential adversaries from pursuing a military build-up in hopes of surpassing, or equaling, the power of the United States."71 Ideally, if the U.S. threat of preventive war is fearsome and credible enough, it will eventually become unnecessary as states will accept the futility of developing WMD, regardless of their intent.

Critics of this strategy warn of a backlash against what may be perceived as U.S. hegemonic impulses, seeking a pliant international system to go with its one-sided sense of security:

\footnotetext{
${ }^{68}$ U.S. Government, National Security Strategy, 15; Rice, Wriston Lecture, 1 October 2002.

${ }^{69}$ Brad Roberts, "The Prospects of Biological War in the Middle East," in The Gathering Biological Warfare Storm, edited by Jim A. Davis and Barry R. Schneider (Maxwell Air Force Base, AL: USAF Counterproliferation Center, April 2002), 161.

${ }^{70}$ Henkin, How Nations Behave, 295.

${ }^{71}$ U.S. Government, National Security Strategy, 30.
} 
At the extreme, these notions form a neoimperial vision in which the United States arrogates to itself the global role of setting standards, determining threats, using force, and meting out justice. It is a vision in which sovereignty becomes more absolute for America even as it becomes more conditional for countries that challenge Washington's standards of internal and external behavior. ${ }^{72}$

Rumsfeld may believe it is America's task "to find and destroy enemies before they strike," but that mission will take place in "a big world" that is responsive to U.S. actions. If opponents are not cowed into forswearing WMD, aggressive American enforcement borne of fear of deterrence failure will probably accelerate proliferation as states will feel compelled to turn to deterrence as their sole source of protection against U.S. conventional power. Worse, a unilateralist attitude toward security may spur additional attacks against American interests, motivating new recruits in the war for terror. As columnist Maureen Dowd succinctly observes: "Terrorism is not, as the president seems to suggest, a finite thing."73 Thus, a fine line exists between trying to gain universal security by eliminating WMD and provoking universal vulnerability by taking actions that lead weaker states and their people to feel desperate and unjustly targeted.

Such concerns are raised with even greater intensity in the aftermath of Iraqi Freedom, as there is evidence of growing popular unrest and terrorist incidents, but not of the scope or depth of threat that the Bush administration implied was present. ${ }^{74}$ The war in Iraq represented a definitive departure from the precepts of Article 51 as well as the principle of necessity, because evidence simply did not exist demonstrating active Iraqi plans (or capability) to attack the United States or its allies. And yet, in some ways, proof of WMD possession or intent is beside the point; the greater danger was that Iraq

\footnotetext{
${ }^{72}$ G. John Ikenberry, “America's Imperial Ambition," Foreign Affairs vol. 81, no. 5 (September/October 2002): 44.

${ }^{73}$ Maureen Dowd, "The Jihad All-Stars," New York Times, 27 August 2003.

${ }^{74}$ Barton Gellman and Walter Pincus, "Depiction of Threat Outgrew Supporting Evidence," Washington Post, 10 August 2003.
} 
would eventually gain nuclear weapons and thereby—as North Korea has shown—shift the balance of power in the region in its favor. Whether this would be strategically significant depends on one's assessment of the durability of deterrence, and in this way the two concepts come full circle: preventive war will become more likely the less confidence there is in deterrence succeeding over the long-run. As was the case in Osiraq, the question was over the likelihood that Hussein would act on his prospective capability. If it was high, then the standard of preventive attack was correctly drawn quite early, before the world had to discover how far Iraq would press its leverage as a nuclear power. If low, then the U.S. action was a very expensive and damaging insurance policy against a risk that perhaps could have been managed in other ways.

Given the difficulty in determining how well deterrence has functioned in the past, predicting its future viability is likely to be a monumental task. As one might expect, there are no easy answers; the numerous incorrect forecasts prior to the Gulf War and Iraqi Freedom are testament to that. And yet, it is possible to lay out the relevant issue areas to help better understand the factors at play in any consideration of preventive war. When such analysis is synthesized for a particular country it represents a "strategic profile" that can serve as the basis for policy recommendations. ${ }^{75}$ First, it is important to consider the risk-tolerance and values of the target state and whether it is likely to remain fundamentally conservative or to be highly motivated to challenge the status quo and threaten the United States. Second, an estimation of U.S. interests in the region will be helpful in determining the overall balance of resolve in a potential conflict. Third, one should calculate the likelihood of success of a military strike, based on the vulnerability of the target state's forces and American offensive capabilities. Fourth, it is worth

\footnotetext{
${ }^{75}$ This section draws on Michele A. Flournoy, "Implications for U.S. Strategy," in New Nuclear Nations: Consequences for U.S. Policy, edited by Robert D. Blackwill and Albert Carnesale (New York: Council on Foreign Relations Press, 1993), 135-161; Philip Zelikow, "Offensive Military Options," in New Nuclear Nations, 162-63; Schneider, Radical Responses to Radical Regimes, 23-26; Roberts, "NBC-Armed Rogues," 83-107.
} 
calculating the likelihood and potential consequences of a retaliatory strike relative to U.S. defensive assets. Finally, one must ask if all other non-military options have been exhausted. If so, the question becomes whether or not the United States has clear objectives and the public support and commitment to carry the action through to completion.

In sum, one must attempt to weigh the risks and rewards of action versus inaction. This is a particularly difficult task because one can never prove that a preventive action was a causal factor in avoiding the occurrence of a greater harm. As one analyst remarked:

It is important to note that most NBC [nuclear, biological, chemical] arsenals have been used not militarily but politically, to coerce a potential adversary to make an important concession (either to do or to refrain from doing something). The costs of this 'use' of NBC weapons cannot readily be compared with the costs of preemptive military attack upon them. ${ }^{76}$

As uncertain as this assessment may be, it is preferable to the sweeping generalizations now in fashion that either promote or condemn preventive war. Absolute proof may not be possible, but we still have the responsibility to make decisions that are as well informed as possible. History has shown that the notion of self-defense-like deterrence-is very much in dispute and in transition. Previously accepted principles and precedents may no longer apply, and yet the appearance of new threats should not lead us to reject widely accepted standards outright. Even if the United States and other nations determine that Article 51 is an unsuitable constraint on self-defense, it is necessary to articulate a new doctrine beyond declaring that the United States will attack its adversaries before they can strike first.

This chapter has analyzed preemptive and preventive war and identified several relevant guidelines when considering anticipatory military action. It suggests that

\footnotetext{
${ }^{76}$ Roberts, "NBC-Armed Rogues," 89
} 
strategic profiles of suspect states are indispensable toward determining whether the United States should pursue engagement, containment, or war. The next chapter will examine North Korea in detail, investigating how these concepts operate in practice. 


\section{Chapter 6}

\section{Modern Dilemmas: North Korea}

Hardly a day passes without a breaking news piece on the turbulence of the occupation in Iraq, an exposé of Iran's suspected nuclear program and the illicit atomic assistance it receives from Russia and Pakistan, or the revelation of new threats and reprisals further damaging the already poisoned relations with North Korea. These nations may not fully live up to their billing as an "axis of evil," but they certainly have drawn a great deal of attention from the international community, especially in the wake of 11 September 2001. They are incredibly diverse nations, yet united by an antagonistic relationship with the United States and a desire to acquire weapons that can place restraints on the U.S. capability to project power in their respective regions. ${ }^{1}$ One common thread running through this dissertation is the troubling uncertainty regarding whether the intention of such arms is primarily defensive, offensive, or a combination of both. If it is defensive, then the United States should take the trend toward regional deterrence capabilities in stride, carefully monitoring suspect states and developing its own defensive technologies, but not using WMD development as grounds for preventive action. If instead there is an underlying aggressive motivation, or propensity to trade and cooperate with terrorist elements, then counterproliferation efforts must supercede doctrines such as deterrence and containment that rely on a more passively oriented adversary. Article 51 can hold no sway in an era when "if an armed attack occurs" there are no measures left for the Security Council to take.

The real world is never so kind as to offer a neat black and white assessment of these perplexing issues. Even with the benefit of hindsight we are often unable to

\footnotetext{
' James M. Lindsay and Michael E. O'Hanlon, Defending America: The Case for Limited National Missile Defense (Washington D.C.: Brookings Institution Press, 2001), 200.
} 
uncover the internal deliberations that lie behind a decision to deter or be deterred. Thus far I have approached the topic of deterrence from a theoretical and historical perspective, considering also the assessment of practical counterproliferation options and the application of moral principles toward choices of preemptive and preventive war. Now it is worth delving into a contemporary example of this phenomenon with a detailed look at the security relationship between the United States and North Korea, one of the most dangerous standoffs in the world. I will first sketch the background of the case, reviewing historical developments since the 1994 Agreed Framework. Then I will work through the essentials of the current crisis, paying particular attention to the threats and bargaining positions of each side. Finally, I will close by completing a strategic profile utilizing the issue areas presented at the conclusion of Chapter Five. This analysis should be useful in better understanding the deterrence interaction of these two adversaries, and how the United States can best craft its foreign policy in the region.

\section{Background}

The Agreed Framework quelled the reprocessing crisis of 1994 by freezing (at least on paper) the North Korean nuclear program, but it hardly brought an end to the persistent tension and heated exchanges on the Korean peninsula. Border flare-ups actually appeared to increase following the agreement, with the downing of an American helicopter in December of 1994 and a major incident involving the infiltration of a DPRK spy submarine less than two years later. DPRK missile development continued apace, and the United States was caught off-guard by the North Korean test of a threestage rocket launched over Japan in 1998, reputedly to send a satellite into space. Suspicions also began to mount that North Korea was in the midst of a covert expansion of its nuclear program involving the construction of a uranium enrichment facility, 
thereby bypassing the plutonium producing reactor at Yongbyon that was shut down by the Agreed Framework. American attention focused on a remote site named Kumchangri, and after protracted negotiations and payment of a hefty fee, U.S. inspectors gained access to what turned out to be a largely abandoned site. ${ }^{2}$ Though embarrassed, the United States was not convinced of North Korean compliance with the Agreed Framework, and as a result its terms went largely unfulfilled, with most phases far behind schedule.

Controversy and dramatic diplomacy have not been exclusive to North Korea's relations with the United States in the past decade. Boundary disputes were common with South Korea, especially over fishing rights and naval patrols, leading to several military skirmishes. At the same time, there have been efforts, albeit inconsistent, toward reconciliation. For instance, after a particularly violent clash in the Yellow Sea in July of 2002, in which five South Koreans were killed, the DPRK issued an unusual expression of regret and called for cabinet-level talks between the two countries. ${ }^{3}$ There have also been heartening steps toward easing the tension along the De-Militarized Zone (DMZ), including the re-linking of cross-border railroads and the first official opening of a land route between the states to allow for tourist visits to Mt. Kumgang in North Korea. ${ }^{4}$ But equally there has been reluctance from the North to de-mine a portion of the DMZ, or to make a major effort at establishing inter-Korean contacts that could help ease the way toward reconciliation. ${ }^{5}$ The few signs of a thaw in political relations between the two Koreas, highlighted by a landmark summit in 2000 as part of former president

\footnotetext{
${ }^{2}$ Marcus Noland, Avoiding the Apocalypse: The Future of the Two Koreas (Washington D.C.: Institute for International Economics, 2000), 159; Kim Myong Chol, "Kim Jong Il's Military Strategy for Reunification," Comparative Strategy vol. 20 (2001): 357.

${ }^{3}$ Don Kirk, "North Korea Regrets Naval Clash With Seoul and Seeks Talks," New York Times, 26 July 2002.

${ }^{4}$ Barbara Demick and Mark Magnier, "The 2 Koreas Get a Land Link," Los Angeles Times, 15 February 2003; James Brooke, "North Korea Moves to Win Some Friends Before Nuclear Talks," New York Times, 5 August 2003.

${ }^{5}$ Thomas A. Schwartz, Hearing on North Korea before the Armed Services Committee, U.S. Senate, Washington D.C., 5 March 2002.
} 
Kim Dae Jung's "sunshine policy," have since been marred by revelations that South Korea paid large sums of money for the North to attend. ${ }^{6}$ Elsewhere in the region, North Korea has made friendly gestures toward Japan by allowing some of the victims of several notorious kidnapping incidents in the 1970 s and 80 s to return home to their families.

Economically, North Korea today is a destitute nation on the brink of starvation. Perhaps with some hyperbole, perhaps not, U.S. Assistant Secretary of State John Bolton described North Koreans as living in a "hellish nightmare."7 Given the extreme secrecy of DPRK society, it is difficult to discern how desperate the financial situation is, but clearly there are enough strains to have forced the government to take the painful steps of initiating a limited program of economic reforms. Over the past year or so, North Korea has begun to phase out its food-rationing system, ease the fixed rates on wages and prices, and allow the creation of a special investment zone on its border with China that has been described as "the most significant reversal of economic policy since North Korea was founded." 8 It remains to be seen what impact these changes will have, though the fact that North Korea plans to wall off the new commercial area from the rest of the country indicates that the DPRK leadership will likely retain a cautious approach. Early assessments (at least of the short-run effects) have been decidedly negative, as the shock of such abrupt liberalizing measures to an economy built on a state-run communist system has led to runaway inflation and widespread shortages. ${ }^{9}$ Sustained economic growth in North Korea will probably remain stunted as long as its main source of

\footnotetext{
${ }^{6}$ Howard W. French, "South Korea Chief Says North Received Cash in Bid for Peace," New York Times, 14 February 2003.

${ }^{7}$ John R. Bolton, "A Dictatorship at the Crossroads," Asian Wall Street Journal, 1 August 2003. This comment then drew the retort from North Korea that Bolton was "human scum" no longer considered an official of the U.S. government. See Glenn Kessler, "N. Korea Seeks to Exclude U.S. Official From Talks," Washington Post, 4 August 2003.

${ }^{8}$ John Larkin, "North Korea Relaxes Economy, Reaches Out to U.S. and Japan," Wall Street Journal, 2 August 2002.

9 John Pomfret, "Reforms Turn Disastrous for North Koreans," Washington Post, 27 January 2003.
} 
revenue comes from arms shipments and drug trafficking rather than industrial production.

Despite these economic woes—and perhaps largely to blame for them-North Korea possesses a formidable military. Its main strength lies in a major artillery arsenal believed to contain some 10,000 long-range pieces, many of which are aimed at Seoul (which is less than fifty miles from the DMZ). ${ }^{10}$ More significant than the number of these weapons is the care with which the North Koreans have shielded them from air attack. The DPRK is renowned for its assiduous tunneling efforts, going so far as to clear out the entire base of a mountain in order to protect sensitive equipment and rocket launchers. Regarding its longer-range capability, after the 1998 missile test, North Korea agreed to a moratorium on launches that lasted until February 2003, when it fired a rocket (believed to have possibly been a long-range cruise missile) into the sea to coincide with the inauguration of the new South Korean president. Despite the absence of testing for several years, few doubt that North Korea's research and development efforts continued without interruption, and U.S. intelligence experts warn of a "nearterm" intercontinental ballistic missile threat from the DPRK. ${ }^{11}$

Even in light of recent assertions and contentious claims, North Korea has remained remarkably vague over its suspected WMD programs. It has claimed possession of a "nuclear deterrence," displayed to private visitors what appeared to be a small amount of plutonium, and hinted at the possibility of an atomic test, but has put forward no direct proof of an advanced nuclear weapons program, preferring to adopt a slightly more conservative stance that it is "entitled" to such weapons for defensive

\footnotetext{
${ }^{10}$ Chol, "Kim Jong Il's Military Strategy for Reunification," 313.

"Michael R. Gordon and Felicity Barringer, "North Korea Wants Arms and More Aid From U.S.," New York Times, 13 February 2003.
} 
purposes. $^{12}$ Such deliberate and barely veiled ambiguity is likely meant to steer a careful path between the sanctions and military strikes that could accompany the announcement of a fully fledged program, and the vulnerability it probably believes it would experience by verifying the true extent of what is likely still a very rudimentary arsenal. This uncertainty is reflected in international intelligence assessments-based on the amount of plutonium North Korea is suspected of extracting prior to 1994-which range from a CIA estimate of one to two weapons, to China's calculation of three to five. ${ }^{13}$ This is not to say that North Korea speaks softly as it carries a concealed stick; in fact, it has been remarkably brash about making threats such as turning the United States into "an agonizing hell of nuclear Armageddon..." if war ever did break out. ${ }^{14}$ Whether this is more smoke than fire, the United States takes such warnings seriously, and is also quite concerned about reports of a robust $\mathrm{CB}$ capability intended to complement an offensive against Seoul or keep American reinforcements from coming to the Korean peninsula in wartime. $^{15}$

North Korea's scorching rhetoric and intense secrecy have served to keep tensions high over decades, with little concrete information known about the intentions or capabilities of the "hermit kingdom." This made the acknowledgement in October of 2002 that it had built a clandestine uranium enrichment facility in contravention of the Agreed Framework all the more dramatic. Presented with what observers have described

\footnotetext{
${ }^{12}$ Bruce Cummings, Korea's Place in the Sun (New York: W.W. Norton \& Company, 1997), 467; Howard W. French, "North Korean Radio Asserts Country Has Nuclear Arms," New York Times, 18 November 2002; Howard W. French, "North Korea Clarifies Statement on A-Bomb," New York Times, 19 November 2002; Anthony Faiola, "N. Korea Claims Nuclear Advance," Washington Post, 3 October 2003. For an account of North Korea's most open presentation of its WMD program, see Siegfried S. Hecker, "Visit to the Yongbyon Nuclear Scientific Research Center in North Korea," Testimony before the Senate Committee on Foreign Relations, U.S. Senate, Washington D.C., 21 January 2004.

${ }^{13}$ Schwartz, Hearing on North Korea; Michael Sheridan, "Koreans May Have Five Nuclear Missiles," London Sunday Times, 27 October 2002; David E. Sanger, "North Korea Open Unofficial Channel for U.S. Talks," New York Times, 10 January 2003.

${ }^{14}$ Chol, "Kim Jong Il's Military Strategy for Reunification," 398.

${ }^{15}$ Joseph S. Bermudez Jr., The Armed Forces of North Korea (New York: I.B. Taurus \& Co Ltd., 2001), 8 and 226; Kyoung-Soo Kim, "North Korea's CB Weapons: Threat and Capability," The Korean Journal of Defense Analysis vol. XIV, no. 1 (spring 2002): 84 and 92; Christopher Torchia, "Suspected N. Korean Chemicals Worry U.S.," Washington Post, 23 August 2003.
} 
as incontrovertible evidence from an American envoy, North Korea initially chose to angrily deny the allegation but eventually decided that admitting to the program was inevitable and could perhaps force the United States into much sought after bilateral negotiations. So began a high stakes cycle of threats, demands, and free-wheeling diplomacy that often seems on the verge of spiraling out of control and highlights the complex interaction of deterrence and counterproliferation.

\section{The Current Crisis}

Discovery of the clandestine uranium enrichment facility confirmed U.S. fears that North Korea had never given up its ambitions to become a nuclear power. As disconcerting as this revelation was, the more immediate danger remained the status of any plutonium that may have been diverted from the Yongbyon reactor, a supply frozen by the Agreed Framework which had the potential to provide the fuel for thirty or more nuclear weapons. ${ }^{16}$ Recriminations and demands flared, with the United States calling for an immediate dismantlement of North Korea's nuclear program and the DPRK insisting upon direct negotiations and a nonaggression pact from the United States. Both sides claimed a sense of betrayal, as the U.S. evidence of deception was countered by North Korean charges that America was not upholding its side of the Agreed Framework and that Bush's "axis of evil" rhetoric was overtly threatening. Faced with a refusal to enter into bilateral talks, North Korea warned that it might recommence testing missiles and began making conflicting statements regarding its nuclear status, perhaps exercising a bit of deliberate ambiguity to raise the stakes.

As in 1993-94, U.S.-DPRK relations fell into a destructive pattern of brinksmanship that escalated the situation to dangerous levels. After the DPRK rejected

\footnotetext{
${ }^{16}$ Doug Struck, "Crisis Could Push N. Korea to Expel Nuclear Inspectors," Washington Post, 14 November 2002.
} 
a last appeal by the IAEA for inspections of the new plant, South Korea and the United States decided to cut off shipments of heavy oil mandated by the Agreed Framework. Then, in December, just as U.S. and Spanish special operations forces were boarding a ship carrying North Korean missiles to Yemen, the DPRK announced that it was lifting the freeze on Yongbyon and two other reactors imposed by the 1994 agreement. This move was particularly alarming in Washington, because it meant that these plants could resume producing spent fuel rods that might then be reprocessed into weapons grade plutonium at a rate sufficient to make over fifty nuclear bombs a year. ${ }^{17}$ Initially, North Korea stopped short of kicking out the IAEA inspectors charged with ensuring that Yongbyon's existing spent fuel rods remained in place. However, two weeks later it chose to remove all of the surveillance cameras and seals from the pond where the fuel rods were stored, stripping them of their monitoring capabilities. ${ }^{18}$

Having effectively returned to the crisis situation of 1994 , both sides began to ratchet up their rhetoric. Building off of President Bush's statement that North Korea's decision to reactivate an idle reactor was "unacceptable," Secretary of Defense Donald Rumsfeld intimated that the United States was still capable of winning two major regional conflicts simultaneously, a fairly direct hint to North Korea given the war planning taking place over Iraq. ${ }^{19}$ The DPRK responded in kind, warning of "uncontrollable catastrophe" and "merciless punishment" if negotiations did not occur. ${ }^{20}$ The North Korean Defense Minister Kim Il Chol asserted that the United States was

\footnotetext{
${ }^{17}$ Bill Gertz, "North Korea Can Build Nukes Right Now," Washington Times, 22 November 2002.

${ }^{18}$ David E. Sanger and James Dao, "North Korea Says it Regains Access to its Plutonium," New York Times, 23 December 2002.

${ }^{19}$ Quoted in David Stout, "Bush and Seoul Call North Korea Nuclear Plan 'Unacceptable," New York Times, 13 December 2002; David Stout, "Rumsfeld Says, if Necessary, U.S. Can Fight 2 Wars at Once," New York Times, 23 December 2002.

${ }^{20}$ Quoted in Howard W. French, "North Korea Warns the U.S. to Negotiate or Risk "Catastrophe," New York Times, 24 December 2002; Howard W. French, "U.S. Gets Warning From North Korea," New York Times, 25 December 2002.
} 
pushing the crisis to the "brink of a nuclear war" and that there would be a "fight to the end" if the United States provoked a conflict. ${ }^{21}$

North Korea wasted no time in creating some provocations of its own. In the last week of December 2002, it officially expelled the IAEA inspectors and moved about 1,000 fresh fuel rods into Yongbyon, an unmistakable signal of willingness to recommence production of plutonium. ${ }^{22}$ Shortly thereafter, the DPRK confirmed its intention to withdraw from the Non-Proliferation Treaty, a perhaps redundant move that nevertheless carried significant symbolic weight. When U.S. satellites began detecting trucks that appeared to be moving the previously quarantined stockpile of 8,000 nuclear fuel rods out of storage at Yongbyon, observers questioned whether all restraints on North Korean actions had been tossed aside as they would now be capable of producing weapons grade plutonium by the end of March $2003 .^{23}$ Alongside the announcement that it would resume "normal operations" at Yongbyon, the DPRK attempted to reassure the world that such work would "at the present stage" only be used for electricity generation. $^{24}$

The United States found little solace in such claims, and the commander of American forces in the Pacific sent a request to Washington for additional air and naval forces to serve as a deterrent against North Korea. ${ }^{25}$ Pentagon officials were careful to mention that such preparations did not signal imminent military action, though the redeployment of twenty-four B-52 bombers to the Pacific island of Guam likely added to

\footnotetext{
${ }^{21}$ Quoted in Christopher Torchia, "N. Korea Warns U.S. Risking Nuclear War," Washington Post, 24 December 2002; Peter S. Goodman, "N. Korean Official Threatens 'Fight to the End' With U.S.," Washington Post, 25 December 2002.

${ }^{22}$ Peter S. Goodman, "N. Korea Moves to Activate Complex," Washington Post, 27 December 2002; James Brooke, "North Korea Says it Plans to Expel Nuclear Monitors," New York Times, 28 December 2002.

${ }^{23}$ David E. Sanger and Eric Schmitt, "Satellites Said to See Activity at North Korean Nuclear Site," New York Times, 31 January 2003.

${ }^{24}$ Howard W. French, "North Korea Restarts Reactor With Ability to Fuel Arms," New York Times, 6 February 2003.

${ }^{25}$ Eric Schmitt and David E. Sanger, "Admiral Seeks Deterrent Force in Korea Crisis," New York Times, 1 February 2003.
} 
North Korea's insecurity. This was the first military response in the escalating crisis, and the diplomatic tension increased in kind. President Bush told reporters that while he believed it was possible to achieve a peaceful resolution to the crisis, "all options are on the table" if diplomacy failed to prevent North Korea from resuming its efforts to build nuclear weapons. ${ }^{26}$ The DPRK renounced the buildup of American "aggression troops" and warned that such moves could lead to a nuclear war that would reduce both Koreas "to ashes." 27 The danger of an accidental or quickly escalating conflict grew even more real as a North Korean MiG fighter jet intruded into South Korean airspace for the first time in twenty years. Only a few weeks later, in March 2003, four North Korean fighter jets intercepted an unarmed American spy plane on a surveillance mission, leading the United States to consider ordering the addition of armed fighter escorts to dissuade future interference.

By the spring of 2003, American intelligence resources were focused intently on trying to uncover any evidence of whether North Korea was reprocessing its spent plutonium. As the supposed "red-line" in the 1993-94 crisis, analysts were disturbed to pick up signs of increasing activity around Yongbyon's reprocessing plant, indicating that there might not be the same level of North Korean restraint as occurred the decade before. $^{28}$ The level of American resolve in holding back the DPRK nuclear program was also uncertain, with some Administration officials hinting that the United States might be tacitly accepting a nuclear North Korea and would instead focus its resources on preventing any sale of missile technology or fissile material. ${ }^{29}$ Complicating efforts to

\footnotetext{
${ }^{26}$ Quoted in James Dao, "Bush Urges Chinese President to Push North Korea on Arms," New York Times, 9 February 2003.

${ }^{27}$ Ibid.

${ }^{28}$ David E. Sanger, "U.S. Sees Quick Start of North Korean Nuclear Site," New York Times, 1 March 2003.

${ }^{29}$ Doug Struck and Glenn Kessler, "Foes Giving in to N. Korea's Nuclear Aims," Washington Post, 5 March 2003; Sonni Efron, "U.S. Said to be Resigned to a Nuclear Korea," Los Angeles Times, 5 March 2003; David E. Sanger, "Bush Shifts Focus to Nuclear Sales by North Korea," New York Times. 5 May 2003.
} 
craft an informed U.S. strategy were the vague and often contradictory reports concerning North Korean progress in reprocessing. For instance, efforts to discover evidence of krypton gas (a tell-tale byproduct of plutonium reprocessing that is emitted into the atmosphere) were generally inconclusive or conflicted with reports that the DPRK was having difficulty even starting up its reprocessing facility. ${ }^{30}$

High hopes for the talks between the United States, North Korea, and China in late April were dashed when the negotiations ended a day early amidst some of the most provocative comments to date. According to reports of the exchange, the North Korean negotiator told an American envoy outside of the official session that the DPRK already possessed nuclear weapons, had begun making bomb-grade plutonium, and that the decision over whether it would market its nuclear materials or conduct an atomic test would depend on American actions. ${ }^{31}$ Once the dust settled from this unexpected confrontation, discussion began to focus on a possible package of U.S. security guarantees and economic assistance in return for DPRK nuclear disarmament. The difficulty, though, just as in 1994, was that neither side seemed willing to take the first steps down this road. New evidence of North Korean reprocessing, coupled with the perception of an increasingly hard-line approach to negotiation, led many Bush administration advisors to consider giving up on a diplomatic solution and instead move to impose sanctions and a tight economic blockade to force compliance.

Over the summer of 2003, progress toward a round of much anticipated sixnation multilateral talks, eventually scheduled for late August, gave the prospects for a diplomatic resolution new life. Bringing the other regional actors to the negotiating table was a primary objective of the United States, which believed that only a united front

\footnotetext{
${ }^{30}$ Glenn Kessler and Walter Pincus, "N. Korea Stymied on Plutonium Work," Washington Post, 20 March 2003; Bill Gertz, " $2^{\text {nd }}$ N. Korean Nuclear Site Not Likely," Washington Times, 22 July 2003; Douglas Frantz, "N. Korea's Nuclear Success is Doubted," Los Angeles Times, 9 December 2003.

${ }^{31}$ David E. Sanger, "North Korea Says it Now Possesses Nuclear Arsenal," New York Times, 25 April 2003.
} 
opposing North Korean nuclear advances would convince it to change its path. Toward that end, the United States worked hard to rally its allies to take an active role in breaking the deadlock with North Korea. In a joint statement with South Korea's new president Roh Moo Hyun, Bush declared that the two countries "will not tolerate nuclear weapons in North Korea" and threatened the use of "further steps" in response. 32 Soon after, Bush met with Japanese Prime Minister Junichiro Koizumi and issued a similar warning against the DPRK building additional weapons. While such summits gave the appearance of a united front, the threats were left deliberately vague largely because both Japan and South Korea remained nervous of the consequences that could follow from taking too coercive a stance against the DPRK. Instead, the Pacific allies put into motion a gradual program of economic restrictions, initiated partly by Japan cracking down on companies that had long been suspected of providing North Korea with equipment used in the development of WMD. ${ }^{33}$ Building off of this, the United States devoted a great deal of diplomatic effort to recruiting a broad range of participants for its Proliferation Security Initiative (PSI), an eleven-nation partnership (not including Russia or China) created to intercept WMD shipments from suspect states like North Korea. The same group also sought to implement a parallel program called the DPRK Illicit Activities Initiative, meant to crack down on North Korea's narcotics trade, counterfeiting, money laundering, and other illegal financial activities. ${ }^{34}$ For the United States, getting other important players like China and Russia on board has been a daunting task, mostly due to their proximity and relatively close relationship with the DPRK. For those two regional actors, fear of a massive refugee crisis in the wake of a collapse of the North Korean

\footnotetext{
${ }^{32}$ Quoted in Joseph Curl, "North Korea Gets Stern Warning," Washington Times, 15 May 2003.

${ }^{33}$ Sachiko Sakamaki and Doug Struck, "Japan Cracks Down on Firms Tied to N. Korea," Washington Post, 22 May 2003.

${ }^{34}$ Steven R. Weisman, "U.S. to Send Signal to North Koreans in Naval Exercise," New York Times, 18 August 2003.
} 
government is tempered only by the equal concern of a nuclear "domino" effect resulting in the decision of South Korea and Japan to pursue their own nuclear weapons programs.

As a more direct security measure, the United States announced that it was initiating a major realignment of American troop deployments on the Korean peninsula, moving many of its soldiers further away from the DMZ. Such a shift, Pentagon officials argued, would save lives from the anticipated artillery barrage along the DMZ in the event of war and preserve a fighting force capable of a decisive counter-attack. ${ }^{35}$ However, as the Cold War amply demonstrated, even reputedly defensive measures can be threatening due to the cover they might provide for offensive plans. In response, North Korea announced for the first time that it was seeking a "nuclear deterrent" to ease the burden of its million-man army, and disclosed that it was making significant progress toward producing enough plutonium for several nuclear bombs. ${ }^{36}$

This backdrop was far from ideal for the multilateral talks, and they broke down in similar fashion to the round a few months earlier. The addition of new participants did little to transform the fundamental dilemma that North Korea was unwilling to bargain away its nuclear program without security guarantees, and the United States would not offer such immunity until it was sure the DPRK was disarmed and unable to transfer WMD abroad. The DPRK rejected a joint accord offered by South Korea, Japan, and the United States laying out a "coordinated" set of steps toward disarmament, preferring instead "simultaneous" moves that did not leave it open to attack. ${ }^{37}$ A North Korean counterproposal raising the prospect of a nuclear freeze in return for energy aid was

\footnotetext{
${ }^{35}$ Howard W. French, "Official Says U.S. Will Reposition its Troops in South Korea," New York Times, 3 June 2003.

${ }^{36}$ David E. Sanger, "North Korea Says it Has Made Fuel for Atom Bombs," New York Times, 15 July 2003.

${ }^{37}$ Glenn Kessler, "U.S. Agrees to Statement on North Korea Talks," Washington Post, 8 December 2003; Sang-hun Choe, "North Korea Rejects U.S. Nuclear Proposal," Philadelphia Inquirer, 15 December 2003.
} 
likewise turned down by President Bush as inadequate. ${ }^{38}$ Consequentially, plans for a follow-up round of multilateral talks nearly fell through, and were largely ineffectual when they did finally occur in late February $2004 .^{39}$ A visit by an unofficial U.S. delegation in early January resolved little, and even resulted in North Korea denying the existence of the uranium enrichment facility that had sparked the entire controversy a year and a half earlier. ${ }^{40}$ And so, the United States and its allies press on with military interdiction exercises associated with the PSI, even as they puzzle over the full extent of North Korea's progress toward reprocessing and weapons production. Just as a decade ago, the options available for resolution are becoming ever narrower and unpalatable, as the DPRK continues steadily toward what will likely be an eventual open and unambiguous declaration of nuclear possession.

\section{Strategic Profile}

In a 1939 radio broadcast, Winston Churchill conceded the virtual impossibility of forecasting the next move of the Soviet Union, remarking that the Communist state was "a riddle wrapped in a mystery inside an enigma." 41 And yet, he continued that the key to the puzzle may lie in a consideration of Soviet national interests. If there is one country that ought to inherit the mantle for a reputation of inscrutability, it would be North Korea. The reclusive state boasts an unmatched level of secrecy and intrigue, and is run by a leader reported to have kidnapped a South Korean actress and film director so

\footnotetext{
${ }^{38}$ Soo-Jeong Lee, "Bush Rejects N. Korea's Offer of Nuclear Programs Freeze for Energy," Washington Post, 10 December 2003.

${ }^{39}$ Joseph Kahn, "North Korea Says it is Against More Talks," New York Times, 30 August 2003; Barbara Demick, "N. Korea Says it Will Be a No-Show at Six-Party Talks," Los Angeles Times, 10 December 2003; Joseph Kahn, "Diplomats See Modest Progress in North Korea Nuclear Talks," New York Times, 28 February 2004.

${ }^{40}$ Barbara Demick, "N. Korea Denies It Has a Warhead," Los Angeles Times, 13 January 2004; Philip P. Pan, "Nuclear Talks Clouded by N. Korea's Denial of Enrichment Effort," Washington Post, 25 February 2004.

${ }^{41}$ Winston S. Churchill: His Complete Speeches, 1897-1963, vol. 6, edited by Robert Rhodes James (New York: Chelsea House Publishers, 1974), 6161.
} 
he could have movies made to order. Intelligence services worldwide appear to be as much in the dark as analysts and commentators, with many news breakthroughs coming from defector reports and most negotiations conducted in private behind-the-scene channels. As Churchill observed, such uncertainty ought not to engender complacency, but rather focus attention on a calculation of interests, which perhaps can be a useful indicator of a likely strategy. This last section will begin with exactly that approach (as outlined in Chapter Five), investigating the possible intentions of North Korea based on its goals, values, and risk-tolerance. It will then move on to look at U.S. interests in the region and its associated level of resolve in any potential conflict. Next, I will briefly examine the prospects for a successful American preventive strike on North Korean WMD assets, and then couple that with an account of the likelihood and consequences of a retaliatory strike by the DPRK. Finally, I will consider other policy options open to the United States, before offering a conclusion of how the United States ought to frame its strategy to best deal with the profile North Korea appears to present.

DPRK Intentions: Divining the political and strategic goals that North Korea hopes to achieve through its WMD program is admittedly a daunting task, but one that merits special consideration given its relevance to crafting an American response. If the DPRK perceives its burgeoning arsenal as a militarily useful tool, the proper opposing disposition of forces and doctrine will be entirely different than if North Korea is truly solely trying to deter a preemptive attack on its facilities. Victor Cha provides a very useful illustration of this underlying uncertainty, depicting the North Korean WMD program in metaphorical terms as potentially a shield meant to provide protection from attack, a sword intended for aggressive or revisionist purposes, or a badge to serve as a 
symbol of prestige as well as confer leverage in talks. ${ }^{42}$ Most unsettling of all is the possibility that the suspected WMD could have multiple ends, for a strong shield can offer a great incentive to brave an attempt at wielding the sword. Likewise an impressive and provocative shield can simultaneously serve as a kind of badge, serving notice of the respect that ought to accompany retaliatory capabilities.

Taking these possibilities in reverse order, the persistence with which North Korea ties its WMD programs to negotiations lends credence to the view that they are primarily a bargaining chip to elicit more substantial economic and political concessions. ${ }^{43}$ The 1994 Agreed Framework was probably the most explicit quid pro quo, linking a freeze in plutonium reprocessing to American and South Korean shipments of oil and the planned construction of a light-water reactor. This deal led many to believe that North Korea was not determined to develop a nuclear arsenal regardless of cost but was perhaps capitalizing on the one sensitive area that could bring such a poor country respect, attention, and financial gain. At the same time, a growing number of analysts believe that the DPRK views its nuclear "card" as too valuable to be played only once and instead will retain it as a hidden trump used both for protection and leverage. $^{44}$ Indeed, CIA Director George Tenet testified last year that Kim Jong II appeared to be attempting to negotiate an implicit tolerance of North Korea as a nuclear state, even as he invoked such a threat to spur an improvement in relations. ${ }^{45}$ Support for the bargaining chip theory of DPRK nuclear status is sharply undermined by North Korea's determined attempts to further refine and diversify its research and production,

\footnotetext{
${ }^{42}$ Victor D. Cha, "North Korea's Weapons of Mass Destruction: Badges, Shields, or Swords?" Political Science Quarterly vol. 117, no. 2 (summer 2002): 211.

${ }^{43}$ Chung Min Lee, "Coping with the North Korean Missile Threat: Implications for Northeast Asia and Korea," in Emerging Threats, Force Structures, and the Role of Air Power in Korea, edited by Natalie W. Crawford and Chung-in Moon (Santa Monica, CA: RAND, 2000), 225.

${ }^{44}$ Andrew Mack, "A Nuclear North Korea," World Policy Journal vol. XI, no. 2 (summer 1994): 27; Joel S. Wit, "North Korea: The Leader of the Pack," The Washington Quarterly vol. 24, no. 1 (winter 2001): 88.

${ }^{45}$ George J. Tenet, Hearing on "The Worldwide Threat in 2003: Evolving Dangers in a Complex World," before the Select Committee on Intelligence, U.S. Senate, Washington D.C., 12 February 2003.
} 
hardly a sensible economic approach for an asset that is meant to be traded away. In this light, the badge characterization might be more appropriate since continual nuclear development maintains international attention and keeps the possibility of further concessions within reach.

If the depth and scope of North Korea's nuclear program belie its use solely as a bargaining chip, then we must give special attention to military efforts that could indicate the DPRK's intention of brandishing an atomic bomb as a "sword" to either attack directly, provide strategic cover for a conventional assault, or coerce South Korea and its allies. To be sure, we must weigh evidence of reputed North Korean offensive designs in context of the over fifty years that have passed without a major armed conflict on the Korean peninsula. At the same time, it is possible that the introduction of a nuclear equalizer on the DPRK side, no matter how drastically outnumbered by the U.S. arsenal, could create the perception of a military balance in North Korea's favor, one that might even prompt a more bold and risk-accepting policy on its part. As far as force disposition can illuminate, North Korea's extreme forward troop concentration-over seventy percent of its army is stationed south of Pyongyang-seems to reveal a preemption-friendly belief in the advantages of the offense and the importance of holding Seoul at risk with little tactical warning. ${ }^{46}$ The difficulty with such analysis, however, is that it is equally plausible that such a seemingly aggressive deployment could merely serve as a credible threat of a deterrent nature. The familiar security dilemma concept obscures the true intent behind North Korean military enhancements including infantry mechanization, the addition of thousands of long-range artillery tubes, and the expansion of special operations forces. ${ }^{47}$ Do such changes, which are especially suited to carrying

\footnotetext{
${ }^{46}$ Schwartz, Hearing on North Korea; Victor D. Cha, "Hawk Engagement and Preventive Defense on the Korean Peninsula," International Security vol. 27, no. 1 (summer 2002): 52; Homer T. Hodge, "North Korea's Military Strategy," Parameters vol. XXXIII, no. 1 (spring 2003): 72.

${ }^{47}$ Cha, "Badges, Shields, or Swords?" 226.
} 
out offensives deep into enemy territory, betray hostile designs? According to Victor Cha, "Since 1980, the KPA have improved their capabilities in ways that are difficult to interpret as wholly defensive."48 And yet, nuclear weapons are a perfect example of a military asset that can truly only be used offensively but may have an underlying, perhaps even primary, defensive purpose. The danger of a spiraling reaction to ambiguous strategic decisions (trying to deter or preempt what one believes could be a preemptive posture by an adversary) is a constant source of danger in international affairs.

North Korea's rhetoric is unlikely to resolve this dilemma, as it oscillates between the desire to be left alone from American aggression and the militant insistence that there will be a reuniting-perhaps by force—of the Korean fatherland. Analyses of the balance of conventional forces across the $\mathrm{DMZ}$ seem to suggest that any North Korean offensive would ultimately be a losing prospect, though there would be tremendous casualties on all sides. One analyst remarks that "[a] traditional armored assault by North Korean forces would amount to putting metal into a metalgrinder, and be fairly straightforward for the allies to stop." ${ }^{, 49}$ The question, of course, is whether the DPRK military leadership has come to the same realization, especially given its efforts at military modernization. Perhaps such investment is a North Korean version of "flexible response," seeking to have adequate conventional means to inflict damage in the event of a U.S. preemptive strike on its nuclear facilities. Or perhaps it is meant to intimidate, and thereby gain concessions from, regional rivals - a prospect that is leading Japan to consider stepping up its retaliatory and preemptive capabilities, possibly even with

\footnotetext{
${ }^{48}$ Victor D. Cha, "Making Sense of the Black Box: Hypotheses on Strategic Doctrine and the DPRK Threat," in The North Korean System in the Post-Cold War Era, edited by Samuel S. Kim (New York: Palgrave, 2001), 185.

${ }^{49}$ Michael O'Hanlon, "Stopping a North Korean Invasion: Why Defending South Korea is Easier than the Pentagon Thinks," International Security vol. 22, no. 4 (spring 1998): 136.
} 
nuclear weapons of its own. ${ }^{50}$ Ironically, the DPRK's apocalyptic images of any war are more indicative of a primarily conservative perspective, since they are based on the acceptance that fighting on the Korean peninsula would be quite costly. This speaks for at least a base understanding of deterrence by North Korea, recognizing that any attack on South Korea or the United States would likely bring immense retaliation. Such awareness diminishes the credibility of any coercive threats of major war, but certainly could provide some confidence that smaller provocations would go unpunished.

If there is limited value to an atomic sword, is the North Korean nuclear program best seen as a shield against a feared United States attack? The available evidence supports this conceptualization, to a point. Many analysts stress the fact that despite its occasional rash behavior, North Korea has generally acceded to compromise in the face of intense international pressure. ${ }^{51}$ Both the Agreed Framework and the missile testing moratorium were examples of concessions that North Korea would not have made had it sought nuclear arms and advanced delivery devices at all costs. The important point to keep in mind is that the DPRK has very legitimate security concerns. As Barry Schneider humorously remarked, “...as the saying goes, just because you are paranoid, does not mean someone is not out to get you. North Korean fears of preemption are not entirely misplaced...."52 North Korea sees the Bush Doctrine, the "axis of evil" appellation, and President's Bush's admission that he "loathes Kim Jong II" collectively as a virtual declaration of war that threatens the very existence of its country. ${ }^{53}$ With

\footnotetext{
${ }^{50}$ Doug Struck, "Threat Erodes Japan's Pacifism," Washington Post, 15 February 2003.

${ }^{51}$ Chuck Downs, Over the Line: North Korea's Negotiating Strategy (Washington D.C.: AEI Press, 1999), 282; Jung-Hoon Lee and Il Hyun Cho, "The North Korean Missiles: A Military Threat or a Survival Kit?" The Korean Journal of Defense Analysis vol. XII, no. 1 (summer 2000): 152; Steven R. Weisman, "Weighing 'Deterrence' vs. 'Aggression,"' New York Times, 18 October 2002;

${ }^{52}$ Barry R. Schneider, Radical Responses to Radical Regimes: Evaluating Preemptive Counterproliferation, McNair Paper \#41 (Washington D.C.: National Defense University Press, May 1995), 32.

${ }_{53}$ Doug Struck, "For North Korea, U.S. is Violator of Accords," Washington Post, 21 October 2002; Julia Preston, "North Korea Demands U.S. Agree to Nonaggression Pact." New York Times, 25 October 2002: Bob Woodward, "A Course of 'Confident Action," Washington Post, 19 November 2002; James T. Laney
} 
such pressure from the world's sole superpower bearing down on a reclusive state with few allies, it is little wonder that the former commander of U.S. forces in Korea expressed concern over the realization of a "cornered rat syndrome."54 North Korea has even gone so far as to express that they "truly fear a U.S. attack," a surprising admission for a state some believe is plotting to stage an attack of its own. ${ }^{55}$

There are several indications that North Korea's protestations of insecurity are not mere diversionary tactics but are in fact genuine. First, the considerable value the DPRK placed on having the United States and South Korea suspend Team Spirit exercises reveals a growing apprehension over the widening gap of military preparedness across the DMZ. ${ }^{56}$ If North Korea truly felt it was in a dominant strategic position on the Korean peninsula, it would probably have far more important bargaining interests. Second, the decision to place the Yongbyon reactor in plain view rather than within a hardened shelter below ground (like much of North Korea's sensitive equipment and artillery) stresses its value as a symbol of deterrence rather than a key military asset. ${ }^{57}$ While the DPRK kept the recently discovered uranium enrichment facility secret and its location is still not precisely known, this may have been due to dissatisfaction with the implementation of the Agreed Framework, and not some belief that nuclear weapons will confer some kind of offensive advantage. Indeed, there is further evidence that the DPRK nuclear program is not well integrated into its military structure-also hinting toward a deterrence mindset rather than a belief in the operational utility of nuclear

and Jason T. Shaplen, "How to Deal with North Korea," Foreign Affairs vol. 82, no. 2 (March/April 2003): 20.

${ }^{54}$ Quoted in Don Oberdorfer, The Two Koreas: A Contemporary History (London: Warner Books, 1997), 314.

${ }^{55}$ Paul Eckert, "N. Korea Still Recognizes '94 Pact With U.S., Ex-Envoy Says," Washington Post, 7 November 2002.

${ }^{56}$ Michael J. Mazarr, North Korea and the Bomb: A Case Study in Nonproliferation (London: Macmillan Press Ltd., 1995), 132.

${ }^{57}$ Cummings, Korea's Place in the Sun, 468. 
weapons. ${ }^{58}$ The recurring theme in North Korean negotiations is a persistent desire for a nonaggression treaty with the United States, the most obvious sign of defensive intentions and legitimate fear. It is because of these factors that most analysts conclude that North Korea desires nuclear weapons as a deterrence failsafe in the event that it cannot secure some guarantee of peaceful intent on the part of the United States. Despite the fact that pursuing an atomic deterrent may bring about the very attack it seeks to avoid, it seems to be a risk North Korea feels it must take.

A final disturbing possibility is that North Korea may see nuclear weapons as a commodity for sale to shore up its failing economy. Such an option, raised by the North Korean negotiator at the April 2003 talks with the United States, cannot be lightly brushed aside given the extensive history of DPRK proliferation activities. Over the last decade North Korea has cooperated with Pakistan by exchanging missile parts in return for gas centrifuges and machinery to assist in enriching uranium. ${ }^{59}$ Furthermore, once such technology or material is out of the country, there is little control over its final destination, as proven by recent revelations of deals for missile and nuclear technology among Pakistan, Iran, and Saudi Arabia. ${ }^{60}$ North Korea's arms contacts extend far and wide, from Yemen to Germany and China, and there is little doubt that there would be many interested buyers for weapons grade plutonium or a completed nuclear device. ${ }^{61}$ At the same time, despite being designated as a prime proliferation threat, there is no evidence that North Korea has sought to export any of its WMD capabilities. Moreover,

\footnotetext{
${ }^{58}$ Cha, "Making Sense of the Black Box," 181.

${ }^{59}$ David E. Sanger, "In North Korea and Pakistan, Deep Roots of Nuclear Barter," New York Times, 24 November 2002.

${ }^{60}$ Douglas Frantz, "Iran Closes in On Ability to Build a Nuclear Bomb," Los Angeles Times, 4 August 2003; Joby Warrick, "Iran Admits Foreign Help On Nuclear Facility," Washington Post, 27 August 2003; David R. Sands, "Israeli General Says Saudis Seek to Buy Pakistan Nukes," Washington Times, 23 October 2003; David E. Sanger and William J. Broad, "From Rogue Nuclear Programs, Web of Trails Leads to Pakistan," New York Times, 3 January 2004.

${ }^{61}$ Bill Gertz, "China Ships North Korea Ingredient for Nuclear Arms," Washington Times, 17 December 2002; Bill Gertz, "N. Korea Ship Gets Arms In and Out," Washington Times, 18 February 2003: Nicholas Kralev, "North Korea Offers Nigeria Missile Deal," Washington Times, 29 January 2004.
} 
as Victor Cha and David Kang have noted, the only link between North Korea and the rest of the "axis of evil" has been financial-related to missile sales. ${ }^{62}$ This may be because transferring any nuclear know-how would be an enormously risky proposition given the extent of U.S. concern. North Korean ties to terrorist entities have largely dissipated, with the main grounds for keeping the DPRK on the U.S. list of statesponsors of terrorism being its lack of support for international efforts to combat terror. The U.S. State Department's Patterns of Global Terrorism acknowledges that North Korea has not sponsored any terrorist acts since 1987, and only makes the vague claim that it has "sold weapons to various terrorist groups."63 North Korea's previous restraint in selling WMD certainly should not inspire confidence that such a policy will continue, especially in light of direct threats to the contrary, but it at least tempers allegations that North Korea is primarily interested in nuclear technology for financial gain. The immense cost, risk, and sacrifice involved in the DPRK nuclear program, far beyond what could likely be recouped, suggest that defensive motivations were probably more central.

As this analysis shows, it is not easy to discern North Korea's nuclear intentions, nor can they be compartmentalized into discrete objectives. In all likelihood, there is no consensus even within North Korea, as the reasons that Kim Il Sung created the program years ago may not be the same as those which lead his son to expand it today. Assuming that Kim Jong Il is the sole decision maker, only he can know the true long-term plan, and even that can change with the circumstances. Nevertheless, social scientists can infer likely costs and benefits, analyze past behavior, and thereby attempt to determine a nation's current strategic interests and probable future choices. In this case, the bargaining positions and military decisions the DPRK has made imply that it views a

\footnotetext{
${ }^{62}$ Victor D. Cha and David C. Kang, "The Korea Crisis," Foreign Policy (May/June 2003): 20 and 22.

${ }^{63}$ U.S. Department of State, Patterns of Global Terrorism, 2002 (Washington D.C.: April 2003), 80-81. See also James Miles, "Waiting Out North Korea," Survival vol. 44, no. 2 (summer 2002): 42.
} 
nuclear capability primarily as a deterrent against the uncertain prospect of U.S. efforts to topple its regime. It is true that North Korea's conventional forces pose a deterrent threat as well, but they may not be as credible in certain limited contingencies, such as a focused preemptive strike. While more aggressive designs, such as coercive diplomacy or exporting plutonium are conceivable, they are not in line with North Korean interests or practice.

U.S. Interests: Given the American troop presence in South Korea and nearby on Okinawa, there can be little doubt that the region is of prime strategic importance to the United States. Ambiguity may pervade the U.S. defense commitments to Taiwan in the event of war with China, but the initiation of hostilities on the Korean peninsula would unavoidably involve American forces. At the same time, whether the United States has sufficient resolve to respond to circumstances short of war, such as the DPRK development of a nuclear arsenal, is unknown. Thus far, American presidents have refrained from issuing an ultimatum regarding the specific nature of consequences that would flow from the creation of a robust North Korean nuclear program. An attempt at regime change along the Iraqi Freedom model is probably out of the question due to the prospect of mass casualties. To this extent at least, it seems apparent that North Korea is able to deter the United States, since Iraq had a considerably less mature nuclear weapons program that nevertheless struck many U.S. policymakers as unacceptably dangerous. ${ }^{64}$ The United States, however, is far from indifferent to a prospective North Korean nuclear arsenal, as is demonstrated by its willingness to contemplate military strikes and sanctions, as well as to offer an array of incentives for DPRK forbearance.

\footnotetext{
${ }^{64}$ Joseph S. Nye, "Hourglass Runs Low," Los Angeles Times, 12 March 2003.
} 
U.S. interests on the Korean peninsula, and regarding the DPRK WMD program in particular, center on four major concerns. ${ }^{65}$ First and foremost, the United States fears that North Korea might choose to sell some of its excess plutonium to other states or possibly even to terrorist organizations. Especially after 11 September 2001, there is an understandable reluctance on the part of the United States to rely on deterrence or to count on being able to interdict a nuclear terrorist plot. As mentioned, exporting WMD is an unlikely ambition of the DPRK, but the disturbing fact is that it will be virtually impossible to know whether such a transfer ever takes place. Sufficient plutonium for a nuclear weapon can be the size of a football, and it is unrealistic for the United States to search all ships leaving port or have any hope of catching smuggling across North Korea's border with China. ${ }^{66}$ Second, since it is difficult to tell how robust the DPRK government is, unintended nuclear proliferation could also occur through the chaos that would likely follow from the fall of Kim Jong Il's regime. As an instructive analogy, immediately preceding the invasion of Iraq, satellite imagery showed a heavy flow of traffic into Syria that some officials believe may have consisted of material from Hussein's weapons program. ${ }^{67}$ Similarly, if North Korea produces and disperses nuclear devices in remote locations to avoid detection and possible destruction, it will be extremely difficult to keep track of weapons stolen by factions looking to turn a quick profit on the black market in the midst of a civil war or coup. As with direct exports, this form of indirect proliferation would also pose a severe threat to the United States if a terrorist group ever tried to make an American city a nuclear target.

Third, in line with the "shield" and "sword" theory of North Korean nuclear objectives, the DPRK may view nuclear weapons as a strategic safeguard to provide

\footnotetext{
${ }^{65}$ Ashton B. Carter, "The Korean Nuclear Crisis," Harvard Magazine vol. 106, no. 1 (September/October 2003): 41. See also Michael E. O'Hanlon and Mike Mochizuki, Crisis on the Korean Peninsula (New York: McGraw-Hill, 2003), 41.

${ }^{66}$ William J. Perry, "It's Either Nukes or Negotiation," Washington Post, 23 July 2003.

${ }^{67}$ Douglas Jehl, "Iraq Removed Arms Material, Aide Says," New York Times, 29 October 2003.
} 
cover for more provocative policies or military coercion. Historically, the Korean People's Army has not been particularly risk-averse in asserting sea boundaries, challenging U.S. reconnaissance missions, and destabilizing the tense stand-off at the DMZ through infiltrations or efforts at intimidation. Hard-liners in the DPRK military hierarchy could use nuclear weapons as a rationale to pursue a more assertive and threatening campaign to gain concessions or perhaps to seek to force steps toward unification on terms more favorable to the North. Even if a nuclear North Korea does not significantly alter the military balance across the DMZ, it will certainly ratchet up yet further the contests of brinksmanship that seem to be a habitual occurrence, and thereby increase the risk of miscalculation, accidents, and disaster. Finally, faced with an unpredictable and existential threat in their midst, some regional actors are likely to seek a stronger guarantee of their security, either through firmer commitments from the United States or by creating a nuclear arsenal of their own. ${ }^{68}$ This nuclear "domino effect" is certainly feasible given that states like South Korea, Taiwan, and Japan all have the technological wherewithal to develop atomic weapons but have been restrained thus far by U.S. pressure and security assistance. While this secondary proliferation would not pose a direct threat to U.S. interests, since these three most immediate neighbors are U.S. allies, it could spur other countries to follow suit and thereby altogether eliminate the fragile normative restraints inherent in agreements like the Nonproliferation Treaty. Efforts to constrain other potential nuclear powers-such as Iran, Syria, and Saudi Arabia-would likely fail due to their hypocritical nature. Besides the self-evident dangers of a nuclearized Middle East, more fingers on nuclear triggers increases in general the danger of catastrophic accidents or failures of deterrence.

\footnotetext{
${ }^{68}$ Marc Dean Millot, "Facing the Emerging Reality of Regional Nuclear Adversaries," Washington Quarterly vol. 17, no. 3 (summer 1994): 56.
} 
Thus, American interests in preventing North Korea from developing nuclear weapons are plainly significant. The dilemma lies in determining what U.S. countermeasures are appropriate in response, given the dangers inherent in both action and inaction. The following two sections will discuss U.S. policy options, beginning with the most controversial: weighing the strategic costs and benefits of an attack on North Korea's nuclear facilities.

Preventive Strike Considerations: Considering that previous promises from North Korea regarding its WMD program have been less than reliable, U.S. strategists are often drawn back to contemplating a unilateral solution by force: conducting an Osiraq-style pin-point attack on Yongbyon and other suspected nuclear facilities. The prospect of a preventive strike was an element of the 1993-94 crisis, and remains an underlying threat behind current negotiations. Some of those options, according to Pentagon contingency plans, include cruise missile strikes on WMD sites accompanied by tactical nuclear attacks against North Korea's hardened artillery positions. ${ }^{69}$ While one might be tempted to dismiss this strategizing as nothing more than unrealistic drawing board sketches, a serious assessment of such plans is appropriate since not only might U.S. offensive means become inevitable if the DPRK chooses to sell WMD or initiate its own attacks, but some respected analysts believe that destroying North Korea's WMD potential is the only certain way to avoid unacceptable proliferation. For instance, James Woolsey and Thomas McInerney, former U.S. government officials, argued in a provocative opinion piece that unless the multilateral talks-with China's help in particular-succeed in terminating North Korea's nuclear weapons program, the United

\footnotetext{
${ }^{69}$ Nicholas D. Kristof, “Secret Scary Plans,” New York Times, 28 February 2003.
} 
States should proceed with an aerial assault to disarm the DPRK, despite the risk of fullscale war. $^{70}$

The principal concerns regarding a preventive strike against North Korea center around two issues: the uncertain likelihood of success and the potential consequences of a retaliatory response. First, the very dearth of intelligence that exacerbates the crisis with North Korea also frustrates the ability to resolve it by force. It is dubious that the United States has the wherewithal to find and destroy facilities that it is uncertain exist. With ambiguous data surrounding North Korea's emission of krypton, U.S. analysts appear unsure as to whether Yongbyon is the primary reprocessing facility or whether an alternative hidden plant exists. ${ }^{71}$ Moreover, there seems to be even less certainty over the location of the uranium enrichment plant that sparked the current controversy in October $2002 .^{72}$ North Korea is masterful in its concealment and deception, moving sensitive activity beneath the Earth's surface where it cannot easily be detected by spy satellites. This burrowing strategy is extensive; South Korea estimates that the North has more than 8,000 underground installations, including 500 kilometers of tunnels. ${ }^{73}$ Assuming for the moment that American and South Korean intelligence agencies have secret knowledge of the location of North Korean nuclear sites, it is highly doubtful that these areas will be vulnerable to conventional air strikes. Underground facilities are not only shielded from prying electronic eyes, but can be constructed to be virtually impervious to aerial bombardment. The U.S. campaign in Afghanistan demonstrated that even multiple attacks with large fuel-air explosive bombs often leave hardened

\footnotetext{
${ }^{70}$ R. James Woolsey and Thomas G. McInerney, "The Next Korean War," Wall Street Journal, 4 August 2003.

${ }^{71}$ David E. Sanger and Howard W. French, "North Korea Prompts U.S. to Investigate Nuclear Boast," New York Times, 1 May 2003; David E. Sanger and Thom Shanker, "North Korea Hides New Nuclear Site, Evidence Suggests," New York Times, 20 July 2003.

72 John Diamond, "N. Korea Keeps U.S. Intelligence Guessing," USA Today, 10 March 2003.

${ }^{73}$ Kongdan Oh and Ralph C. Hassig, North Korea: Through the Looking Glass (Washington D.C.: Brookings Institution Press, 2000), 108.
} 
enclaves protected by natural rock formations unscathed. Worse still, even if such sites could be located and destroyed, since North Korea has already removed (and likely dispersed) the plutonium from the Yongbyon reactor, it can continue with reprocessing virtually anywhere probably undetected. Thus, while the United States could undoubtedly cause substantial damage to North Korea's nuclear facilities, a preventive strike would be unlikely to destroy the plutonium that the DPRK could use either for sale abroad or for future manufacture into nuclear weapons.

Second, the DPRK has many options for causing unacceptable harm both to South Korea and the United States. North Korea may not, despite its boasts, have the capability to send a missile to the continental United States, but it has plenty of missiles with ample range to reach its regional adversaries. The Commander of U.S. Forces in Korea, General Leon LaPorte, estimates that the DPRK possesses over 800 missiles capable of striking the Korean peninsula and surrounding countries. ${ }^{74}$ Add to this an estimated 10,000 artillery pieces, and it becomes clear that North Korea can wreak devastation in the region regardless of whether it has nuclear weapons or not. General LaPorte emphasizes the asymmetric nature of North Korea's threat, which he believes is based on a 120,000 strong special operations force and a doctrine of using CW as munitions. ${ }^{75}$ Though the United States and South Korea have far superior air forces and well-trained armies, the sheer numbers the DPRK can bring to bear in terms of both manpower and artillery mean that any war will be incredibly costly. This is not to say that the ultimate success of the United States and the Republic of Korea in any all-out conflict would be in doubt, merely that it would be a far different conflict from the experience in Iraq.

\footnotetext{
${ }^{74}$ Leon LaPorte, This Week With George Stephanopoulos, ABC News Transcripts, 27 July 2003.

${ }^{75}$ Bill Gertz, "U.S. Commander Fears N. Korea Would Sell Nukes," Washington Times, 18 November 2003.
} 
In principle, it is possible that the United States could launch a preventive strike and not face any retaliation from North Korea-this is the dual nature of deterrence on the Korean peninsula. Given the scale of the air assault that would be necessary to cripple the DPRK nuclear program, however, it is extremely unlikely that a U.S. president, much less his South Korean counterpart, would authorize such an attack in response to an invasion, let alone a highly substantial provocation. Thus, most analysts prefer to bracket a preventive strike as a last-resort and instead focus on other policy options, several of which I examine below.

Policy Alternatives: The simplest approach for the United States is to attempt to "wait out" North Korea, hoping that the passage of time will ease the conflict. Dictatorships cannot last forever, and the dismal state of the North Korean economy would generally suggest that since its people are on the brink of starvation, a popular revolution would be inevitable. Unfortunately, such forecasts have been wrong many times in the past. North Korea is a remarkably hardy and proud country, and it is also a totalitarian dictatorship. Chairman Mao presided over the deaths of more than 20 million Chinese and remained in power, and there is no reason to believe that Kim Jong Il cannot do the same. Leadership mortality is also a false hope; not only is Kim Jong II relatively young, but his successful family transition from Kim Il Sung indicates that the same should be possible to the next generation. Nor is the challenge of nuclear proliferation a long-term prospect that is compatible with a wait-and-see approach. Unlike Iraq, North Korea has a confirmed supply of plutonium and the reprocessing technology to produce weapons grade fuel. It is very possible that North Korea has already completed the reprocessing stage, in which case the danger of transfer or weapons production will persist regardless of what kind of regime is in power. 
The nature of North Korea's leadership is relevant when calculating the extent of the danger posed by its WMD possession. A more moderate DPRK, with a stake in the status quo, would be less likely to push relations to the brink of war or risk the consequences of selling nuclear material abroad. Consequently, to create a positive influence, many analysts advocate a strategy of engagement, encouraging reform and reassuring Kim Jong Il that the United States does not have aggressive intentions. The process of engagement can take many forms, ranging from conciliatory measures (like offering food aid) to more conditional agreements (such as granting trading rights in return for inspections or a freeze on missile testing). The most prominent trade-off under consideration is the exchange of a multilateral security guarantee of some kind for the dismantlement of North Korea's nuclear facilities. Disagreement persists, however, over whether both sides should move simultaneously or in coordinated and reciprocal steps. The U.S. reluctance to offer even a basic unilateral security guarantee is curious given its repeated statements that it is not considering an invasion. According to David Kang, an expert on Korean security, if the United States truly has no intention of starting a war, it should be willing to put it in writing, especially if it leads to important concessions from the DPRK. ${ }^{76}$ One concern is that such a promise could tie the United States' hands in the event that conditions change, with little concrete in return, but it is hard to imagine a scenario short of full-scale war (in which case the guarantee would obviously be void) in which the United States would invade North Korea. ${ }^{77}$ More telling is how adamantly the DPRK appears to desire an agreement that ultimately is based on nothing more than the word and honor of the U.S. president. This demonstrates that North Korea seems genuinely willing to strike a deal of some sort. The DPRK has claimed that "everything

\footnotetext{
${ }^{76}$ Victor D. Cha and David C. Kang, Nuclear North Korea: A Debate on Engagement Strategies (New York: Columbia University Press, 2003), 116.

${ }^{77}$ Peter Grier and Faye Bowers, "Pyongyang Options Opening Up," Christian Science Monitor, 9 January 2003.
} 
will be negotiable" in disarmament talks, and has pursued several private channels of communication to try and jumpstart negotiations. ${ }^{78}$ Such attempts at diplomacy may merely be a diversion to keep the United States occupied while DPRK nuclear development continues apace, but they are substantial enough to signal openness to compromise. After all, North Korea never needed to consent to the Agreed Framework, and-despite the creation of an alternative uranium enrichment facility-it abided by the freeze on Yongbyon for nearly a decade.

On the other side of the coin are those who believe that reform is impossible or highly unlikely and thus recommend a strategy of containment, perhaps with direct efforts to undermine Kim Jong II's regime. Given North Korea's dependence on aid and its limited international trade, the prospect of sanctions is a genuine threat to its wellbeing and security. Several times in the past, North Korea has identified the imposition of sanctions as a casus belli, and perhaps as a result, U.S. officials have ceased pressing for them at the UN Security Council. ${ }^{79}$ A fundamental restraint on U.S. freedom to pursue tough containment measures is the unwillingness of its neighbors, particularly South Korea, to allow the North to fall apart-possibly resulting in an "implosionexplosion" scenario that would be far worse than an unsteady peace. ${ }^{80}$ However, there are several alternative forms of leverage that would not create the same risk of a meltdown and refugee crisis. One idea is to smuggle in small radios-which are currently prohibited by the North Korean government-in order to combat the pervasive censorship over knowledge about the outside world. ${ }^{81}$ Alternatively, encouraging family

\footnotetext{
${ }^{78}$ Philip Shenon, "North Korea Says Nuclear Program Can be Negotiated," New York Times, 3 November 2002; Sanger, "North Korea Open Unofficial Channel for U.S. Talks;" Steven R. Weisman, "Private Group Prepares Visit to North Korea," New York Times, 4 January 2004.

${ }^{79}$ Doug Struck, "U.S. Signals It Won't Seek Sanctions Against N. Korea," Washington Post, 23 January 2003.

${ }^{80}$ Robert A. Manning, "The Enigma of the North," The Washington Quarterly vol. 23, no. 3 (summer 1999): 72; Anthony Lake and Robert Gallucci, "Negotiating with Nuclear North Korea," Washington Post, 6 November 2002.

${ }^{81}$ James Brooke, "Infiltrators of North Korea: Tiny Radios," New York Times, 3 March 2003.
} 
reunions with South Korea and any other forms of cultural exchange or international events will inevitably expose more North Koreans to the extreme deprivation they endure relative to other nations. Unfortunately, any of these "softer" measures are of uncertain efficacy and would have no direct impact on preventing the DPRK from producing nuclear weapons, which is an immediate concern.

The most important containment objective is establishing a regime to prevent North Korea from exporting any fissile material. The Proliferation Security Initiative is the international effort created for this purpose, designed to develop "new means to disrupt WMD trafficking at sea, in the air, and on land."82 The challenge, which may very well be insurmountable, is that plutonium emits a faint radiation signature, complicating the ability to detect its presence in cargo or other transport containers. ${ }^{83}$ Given the quite small size of usable plutonium, along with the relatively porous border between North Korea and China, it becomes evident that interdiction will be an enormously difficult task for the Proliferation Security Initiative. ${ }^{84}$ Numerous opportunities for smuggling exist, and so containment of North Korean nuclear proliferation will ultimately rely less on the ability to actually intercept illegal shipments with high reliability than on the power of deterrence to dissuade the DPRK from ever attempting to transfer due to the potential consequences.

Conclusions: Naturally these policy alternatives are not mutually exclusive; in his well-known recommendations, former Defense Secretary William Perry urged the United States to present North Korea with two paths-engagement and containmentwhich would be dependent on the DPRK's disarmament choices. ${ }^{85}$ Victor Cha likewise

\footnotetext{
${ }^{82}$ John R. Bolton, Remarks to the Conference of the Institute for Foreign Policy Analysis and the Fletcher School's International Security Studies Program, Washington D.C., 2 December 2003.

${ }^{83}$ Sonni Efron, "U.S. Officials in a Quandary Over N. Korea," Los Angeles Times, 8 May 2003.

${ }^{84}$ O'Hanlon and Mochizuki, Crisis on the Korean Peninsula, 34.

${ }^{85}$ William J. Perry, "Review of United States Policy Toward North Korea: Findings and Recommendations," 12 October 1999.
} 
argued that engagement is intertwined with containment because "today's carrots can be tomorrow's sticks," lending justification and support for harsher options should North Korea reject attempts at conciliation. ${ }^{86}$ The trouble is that this metaphorical transformation can occur in either direction; it appears that the possibility of removing sanctions (the "stick") against Libya became a very appealing "carrot" to motivate Gaddafi's acceptance of an inspections regime. ${ }^{87}$ The fact that Libya held firm for several decades and developed a surprisingly robust WMD program in the meantime, though, should give pause to applying this model to North Korea.

As many commentators ruefully note, the dilemma with North Korean negotiations is that there are few attractive options: too strong a position lacks credibility because the United States is unwilling to seriously risk war on the Korean peninsula unless America or its allies are gravely endangered, but too soft a line could embolden the DPRK to develop and disperse its program until only a full-scale conflict (or complete and unconditional inspections, which would become less and less likely as the program advanced) could eradicate it. Thus far a happy medium has been elusive, and there is speculation as to whether North Korea truly desires a settlement that would irreversibly terminate its WMD potential. However, this speculation must be tested since it is clearly the most desirable outcome by far. The Proliferation Security Initiative cannot possibly be infallible, and so the potential for North Korea to transfer plutonium to terrorists will be omnipresent-an extremely disturbing prospect. One would expect that the United States would pursue any and all avenues to avoid this nuclear sword of Damocles, even if the likelihood of transfer were extremely low. This makes the Bush Administration's refusal to consider direct talks with North Korea particularly incomprehensible. The demand for multilateral participation is so strong that after

\footnotetext{
${ }^{86}$ Cha, "Hawk Engagement and Preventive Defense," 72.

${ }^{87}$ David Stout, "Bush Says Libya Will Allow Arms Inspections," New York Times, 19 December 2003.
} 
Richard Armitage, the Deputy Secretary of State, suggested in Congressional testimony that bilateral negotiations were likely to take place, Bush directed that all U.S. officials no longer even publicly discuss the option of one-on-one talks. ${ }^{88}$ This might be an acceptable stance if the United States had the upper hand in negotiations, but the harsh reality is that time is on North Korea's side, and stonewalling will only allow its nuclear program to become further entrenched and therefore more difficult to dismantle and less likely to be willingly bargained away.

Past North Korean indiscretions and its violation of the 1994 Agreed Framework make the United States understandably reluctant to enter into another agreement that is not fully verifiable and permanent. However, even if the end goal is inflexible, the means toward achieving it must be. The Bush Administration's rhetoric is not always the most conducive to positive relations and an atmosphere of compromise that may be indispensable to resolving the conflict. For instance, John Bolton's now infamous speech in Seoul in July 2003 lambasted Kim Jong II as a tyrannical dictator and mentioned him by name forty-one times. ${ }^{89}$ President Bush has also personalized the issue, confiding to correspondent Bob Woodward that he loathed Kim Jong Il and had a "visceral reaction to [the] guy." negotiating style that denies personal contacts and makes offensive remarks such as these is antithetical to Korean notions of allowing an opponent to "save face" and retain honor. ${ }^{91}$ Another analyst has studied North Korean negotiating behavior and concludes that it follows a tit-for-tat strategy, meeting threats with threats and cooperation with cooperation, with obvious implications for a negative and combative U.S. approach. ${ }^{92}$

\footnotetext{
${ }^{88}$ Sanger, "U.S. Sees Quick Start of North Korean Nuclear Site."

${ }^{89}$ Bolton, "A Dictatorship at the Crossroads."

${ }^{90}$ Woodward, "A Course of "Confident Action."

${ }^{91}$ Mazarr, North Korea and the Bomb, 207.

${ }^{92}$ Leon V. Sigal, Disarming Strangers: Nuclear Diplomacy with North Korea (Princeton, NJ: Princeton University Press, 1998), 125.
} 
Even if such American feelings are strongly held and fully justified, they have dubious value for diplomacy, especially when talks are at a standstill. This is not meant to imply that the United States is solely at fault-after all, North Korea has given its fair share of bombastic and threatening rhetoric-merely that it is worth considering whether a cycle of negative feedback is more responsible for poisoning relations than actual irreconcilable differences.

If the United States and North Korea truly have incompatible security interests, then no amount of talking, no matter how civil, will suffice to break the impasse. Along with flexibility over methods of negotiation, though, must come flexibility over the content of negotiations. This does not mean the United States should make unilateral concessions, but it should be forthcoming with a reasonable package of incentives to test North Korea's willingness to trade away its nuclear program. It does not, for example, seem plausible to expect that North Korea would voluntarily disarm before receiving any guarantees of its security. As discussed in the intentions section, North Korea would be understandably loathe to trade in a nuclear shield that thus far has proven quite effective for a paper shield based on a promise from its sworn enemy. The timing of this bargain, which seems quite favorable to the United States, should not be preventing its completion. Imagination on the terms of a compromise is essential; Michael O'Hanlon argues that since America's allies do not want a coercive strategy, it should consider a grand package that would offer extensive aid and security assurances in return for liberalization measures and a reduction in North Korea's military forces. ${ }^{93}$ Regardless of the specific terms, the United States and its allies must put forward a comprehensive offer soon, since the demand for extra incentives will only grow as the DPRK program becomes more robust.

\footnotetext{
${ }^{93}$ Michael O’Hanlon, “Think Bigger on North Korea," Washington Post, 17 September 2003.
} 
If form and content fail to achieve a settlement that results in the dismantlement of North Korea's nuclear programs, the United States will face some difficult choices. First, it will have to decide whether military action or a strategy of containment is appropriate to achieve disarmament by force and coercive pressure. This decision carries an unmistakable risk of full-scale war on the Korean peninsula, including perhaps attacks on Japan and the U.S. mainland, and so would be a remarkably risky enterprise. Whether to proceed would depend on an assessment of the likelihood of North Korean regional aggression or nuclear proliferation. To keep this calculation as favorable as possible, the United States should make an unambiguous and public announcement to North Korea that any type of WMD transfer will lead to the most severe of consequences. Establishing "red-lines" can be a dangerous business, but in this case the line should be very credible indeed. On the one hand, this arrangement could serve to inspire other nations to pursue WMD in order to achieve similar immunity from U.S. attack. On the other, it is undeniable that nuclear weapons are powerful tools of deterrence, and the desire to set a precedent and use North Korea as an example should not come at the cost of Seoul and countless thousands of lives. If anything, the North Korean situation should serve as a spur for the United States to make even greater efforts to come to some sort of arrangement with states like Iran and Syria, as it appears to have done with Libya. If those terms prove unacceptable, then the United States and its allies have no choice but to invest in counterproliferation and defensive technologies to disarm its foes by force or diminish the damage if war ever does break out.

With North Korea, the United States must make clear that any form of regional aggression or coercion will be fruitless, and any transfer of WMD technology or material will be met with a strong response. It should attempt to reach a negotiated solution, in a professional and flexible manner, but be prepared for the consequences of failure. The 
Proliferation Security Initiative is not a satisfactory palliative, and should not lend any encouragement to the United States to dig in its heels and demand an agreement on its terms. $^{94}$ It is North Korea that holds the advantage of effectively being on the defensive; it is the United States that has the "last clear chance" to avoid disaster. Fortunately the DPRK appears sensitive to deterrence, and willing to reach a negotiated resolution to the conflict. It would be a profound mistake not to make every effort to test this opportunity. If it proves to be a false hope, then the United States will be no worse for trying, save the lost time of negotiation.

\footnotetext{
${ }^{94}$ This appears to be what President Bush attempted to communicate when he directed his envoy at the multilateral talks in February 2004 to inform the North Korean delegation that America's patience in a seeking a diplomatic solution was running out. See Glenn Kessler, "Bush Signals Patience on North Korea is Waning," Washington Post, 4 March 2004.
} 


\section{Chapter 7}

\section{$\underline{\text { Recommendations and Conclusions }}$}

The last few years have brought a sea of change to international affairs. 11 September 2001 shattered America's sense of security and triggered a surge in global indignation that provided moral support for the war in Afghanistan. World sympathy quickly transformed to suspicion as U.S. attention shifted to Iraq, and the intelligence failures and political unrest in that defeated country have led many people both in America and around the globe to question U.S. intentions. One virtual constant amidst the tumult has been the United States' military dominance; if anything, America's relative advantage is growing over its closest rivals. ${ }^{1}$ The troubling result is that such undisputed superiority is not making the United States safer. Rather, it is spurring an underground network of trade in unconventional technology and weapons that is both increasing American vulnerability to catastrophic acts of WMD terrorism and decreasing the credibility of U.S. commitments to resolve regional crises and conflicts in its favor.

Chapter One introduced this dilemma, observing that there is a crisis of confidence regarding the durability of deterrence. In apparently contradictory fashion, deterrence seems simultaneously insufficient to reliably dissuade so-called "rogue states" from harming the interests of the United States and its allies, but potent enough to possibly keep the latter from intervening in such threatening situations. Chapter Two applied a theoretical lens to this puzzle, explaining how asymmetries of interest and brinksmanship techniques can confer a strategic advantage beyond what one would expect from a pure comparison of military capability. Estimations of resolve are directly linked to subjective variables such as risk sensitivity and degree of commitment, each based on psychological factors that may not be strictly rational. Chapter Three

\footnotetext{
' Gregg Easterbrook, "American Power Moves Beyond the Mere Super," New York Times, 27 April 2003.
} 
demonstrated how these concepts play out in real-world regional conflicts; both the 1990-91 Gulf War and the 1993-94 crisis between the United States and North Korea were rife with deterrent threats, efforts to manipulate credibility, and the disconcerting omnipresent potential for the use of WMD.

Faced with these experiences, U.S. policymakers now confront the challenge of crafting a strategy in response to the increasing proliferation of WMD. As articulated in Chapter Four, one option is to adopt a quasi-isolationist stance-responding only to overt regional aggression and relying on deterrence to prevent attacks on the United States and its allies. However, the major drawback to this posture is that there is no bright line between an unambiguous armed offensive and more subtle forms of coercion and interference. Moreover, the nexus between terrorist organizations and state sponsors reduces the appeal of a reactive approach since non-state actors have less to fear from an American retaliatory response. Instead, the Bush administration has adopted a comprehensive counterproliferation strategy that includes defensive elements such as a missile defense system and WMD detectors, but also contemplates offensive counterforce operations to eliminate the threat altogether. Chapter Five elaborated on the moral, legal, and political difficulties inherent in any choice for preemptive or preventive war, including the immense practical barriers to carrying out a successful attack. Not only will the United States generally lack adequate intelligence to support a strike on suspected WMD sites, but the diplomatic consequences will be overwhelmingly negative in all but the most extreme circumstances. Finally, Chapter Six, in outlining a strategic profile of North Korea, illustrated the troubling inverse relationship between knowledge of a state's WMD capabilities and the ability to destroy suspect facilities or negotiate their dismantlement. In contrast to the aggressive sanctioning and pressure the world community placed on states with less advanced WMD capabilities like Libya and Iraq, 
North Korea has a much more mature program and must therefore be treated with greater caution. Other regional powers that feel threatened by U.S. encroachment will likely seek a similar form of immunity through advanced WMD programs unless the United States can alter their incentives or strategic calculations.

It is clear that there is no uniform strategy for responding to the proliferation of WMD. The United States would be foolhardy to embark on a global crusade to rid the world of weapons and evil regimes; in fact, there is an inherent tension between striking a threat at its source, and that action eventually contributing to the very source of the threat. ${ }^{2}$ Power alone can never change people's hearts and minds, and since the decision of whether to use WMD will ultimately always rest with the adversary, a long-term development toward peaceful relations is the best hope for security. At the same time, there are some states and organizations that pose too great a danger to adopt a "wait and see" approach. It is frightening to think of a terrorist group like Al Qaeda finding a true sanctuary behind a fully WMD-armed nation, or taking over a vulnerable nuclear state such as Pakistan. Containment can be a very effective and prudent doctrine, but only against those regimes that accept the status quo and judge that the balance of deterrence is not in their favor. Those that believe otherwise, or do not care about consequences, must be dealt with in a different manner. Secretary of Defense Rumsfeld cautions:

I think realistically we have to face up to the fact that we live in a world where our margin for error has become quite small...we have to recognize that terrorist networks have relationships with terrorist states that have weapons of mass destruction and that they inevitably are going to get their hands on them, and they would not hesitate one minute in using them. That's the world we live in. ${ }^{3}$

\footnotetext{
${ }^{2}$ Richard K. Betts, "The New Threat of Mass Destruction," Foreign Affairs vol. 77, no. 1 (January/February 1998): 40.

${ }^{3}$ Donald H. Rumsfeld, Hearing on FY 2003 Appropriations for the Defense Department before the Appropriations Committee, U.S. Senate, Washington D.C., 21 May 2002.
} 
By way of illustration, the critical question is if the United States determines it cannot afford to count on the adversary always swerving in these international games of "chicken," what policies_-driving an armored car, killing the other driver, avoiding the contest altogether-ought the U.S. to follow?

I suggest that deterrence must be refashioned to incorporate counterproliferation strategies, bolstering U.S. defensive capabilities so that an adversary's WMD threat is drained of its coercive power. In the end, America's willingness to accept risks and, if necessary, to absorb or deflect costs in regional conflicts will determine whether deterrence will favor the United States or its adversaries in the age of WMD. This final chapter will analyze the most important components of an effective U.S. global strategy, providing recommendations in two broad areas: diplomacy and technology.

\section{Diplomacy}

More and more, citing the war in Iraq, various broken or failed multilateral treaties, and a general hegemonic disposition, commentators describe the United States as a nascent imperial power. ${ }^{4}$ Usually intertwined with this observation is the premonition that empires tend toward excess, carrying the seeds of their own destruction within the cyclical need to expand in order to protect their ever-broadening interests. According to one analyst:

America's nascent neoimperial grand strategy threatens to rend the fabric of the international community and political partnerships at a time when that community and those partnerships are urgently needed....And if history is a guide, it will trigger antagonism and resistance that will leave America in a more hostile and divided world. 5

\footnotetext{
${ }^{4}$ G. John Ikenberry, “America's Imperial Ambition,” Foreign Affairs vol. 81 no. 5 (September/October 2002): 44-60; Stephen Peter Rosen, "An Empire, If You Can Keep It," National Interest vol. 71 (spring 2003): 51-62; Dimitri K. Simes, "America's Imperial Dilemma," Foreign Affairs vol. 82, no. 6 (November/December 2003): 91-102.

${ }^{5}$ Ikenberry, "America's Imperial Ambition," 45.
} 
The dissension at the UN Security Council in February of 2003 over Iraq was proof positive of the fraying multilateral support for American foreign policy. To be fair, it would be unreasonable to expect homogeneous interests across such a diverse range of states. There are divergent perceptions of threat, and indeed different degrees of actual vulnerability. The United States is much more at risk than Norway of suffering a terrorist attack from $\mathrm{Al}$ Qaeda, and will have a correspondingly more assertive and uncompromising security perspective. Given this context, the mere presence of international disagreement is not sufficient proof that U.S. strategy has gone awry. In certain cases, as with missile defense, fierce initial resistance gave way to grudging acceptance and even active support from some allies. ${ }^{6}$ In other cases, as with the International War Crimes Court and the Kyoto Protocol, the world community ignored American opposition and pressed on regardless, leaving the United States on the sidelines as other nations developed new institutions and regulatory frameworks. This is not to say that the United States should blindly accede to every multilateral agreement or security arrangement, merely that it should carefully choose its battles, since a perception of U.S. intransigence gained through relatively insignificant issues can have a disproportionate effect when weightier concerns come into play. On balance, the United States ought to follow a unilateral path very reluctantly, accepting short-term compromises in the pursuit of a long-term and ultimately preferable cooperative international environment. ${ }^{7}$

Fortunately, there seems to be relatively uniform interests regarding WMD, especially when non-state actors are involved. As the 2002 National Security Strategy (NSS) noted: "Today, the world's great powers find ourselves on the same side-united

\footnotetext{
${ }^{6}$ Marc Lacey, "Powell Fails to Persuade NATO on Antimissile Plan," New York Times, 30 May 2001; James Brooke, "A Missile Shield Appeals to a Worried Japan," New York Times, 11 November 2002; Michael Evans, "Britain 'Needs Missile Shield," London Times, 13 November 2002.

${ }^{7}$ Joseph S. Nye Jr., The Paradox of American Power: Why the World's Only Superpower Can't Go it Alone (Oxford: Oxford University Press, 2002), 158.
} 
by common dangers of terrorist violence and chaos." ${ }^{\prime 8}$ The United States needs multilateral cooperation on this issue; the range of threats are simply too widespread to be managed alone, no matter how "imperial" the effort. The WMD black market spans the globe, stretching from a secret BW cache in South Africa to the nuclear bazaar centered in Pakistan —each led by nominally friendly governments—and virtually everywhere in between. ${ }^{9}$ In proposing the Proliferation Security Initiative (PSI), the Bush administration implicitly recognized the essential role American allies will play in providing intelligence and local expertise to interdiction efforts. Undersecretary of State John Bolton remarked:

The national legal authorities of each participant will allow us to act together in a flexible manner, ensuring actions are taken by participants with the most robust authorities in any given case. By coordinating our efforts with other countries, we draw upon an enhanced set of authorities for interdiction. ${ }^{10}$

President Bush confirmed this multilateral approach in his February 2004 speech at the National Defense University, announcing that he intends the PSI to expand both in membership and in the scope of shipments and transfers it target. ${ }^{11}$ Bush also emphasized the need to create international laws criminalizing the proliferation of WMD and requiring strict export controls and border security measures from all nations. A legal regime is necessary to legitimize the function of the PSI since many shipments of

\footnotetext{
${ }^{8}$ U.S. Government, The National Security Strategy of the United States of America (Washington D.C.: September 2002), forward.

${ }^{9}$ Joby Warrick and John Mintz, "Lethal Legacy: Bioweapons for Sale," Washington Post, 20 April 2003; David E. Sanger and William J. Broad, "From Rogue Nuclear Programs, Web of Trails Leads to Pakistan," New York Times, 3 January 2004.

${ }^{10}$ John R. Bolton, Remarks to the Conference of the Institute for Foreign Policy Analysis and the Fletcher School's International Security Studies Program, Washington D.C., 2 December 2003.

${ }^{11}$ George W. Bush, Remarks on Weapons of Mass Destruction Proliferation, Fort Lesley J. McNair, National Defense University, Washington D.C., 11 February 2004.
} 
illicit weapons on the high seas are actually legal if undertaken by states not party to certain export treaties. $^{12}$

The role of international organizations, particularly the International Atomic Energy Agency (IAEA), is prominent in Bush's vision, and parallels IAEA Director Mohamed ElBaradei's call for empowering inspectors to close off loopholes inherent in the NPT. ${ }^{13}$ The IAEA has had a mixed record in uncovering secret WMD programs, but it is becoming an increasingly prominent player in mobilizing pressure on suspect states to submit to more intensive inspections. ${ }^{14}$ The IAEA is indispensable in this process because it confers international legitimacy on nonproliferation efforts, defusing claims from target states that they are merely victims of an American-led witch hunt. As is evident with Iran, and was apparent in Iraq, the major difficulty is that inspections are ultimately at the discretion of the host country, and so there are not necessarily any immediate consequences to rejecting an IAEA request for access. ${ }^{15}$ However, the IAEA can be a useful intermediary while other states bring coercive tactics to bear, as occurred in late 2003 when the United States and a European consortium eventually reached a rough compromise with Iran over how to proceed with inspections. ${ }^{16}$

Perhaps more important than inspecting suspect states is cutting off their supply of WMD technology and employing economic incentives for voluntary disarmament. A combination of demonstrating how futile and costly WMD acquisition will be relative to the financial gains of coming clean may suffice, especially with states that face as much of a threat internally from popular unrest over a stagnating economy as externally

\footnotetext{
${ }^{12}$ Benjamin Freedman, The Proliferation Security Initiative: The Legal Challenge, Policy Brief (Washington D.C.: Bipartisan Security Group, September 2003), 1.

${ }^{13}$ Mohamed ElBaradei, "Saving Ourselves From Self-Destruction," New York Times, 12 February 2004.

${ }^{14}$ Fred Barbash, "U.N. Nuclear Agency Censures Iran," Washington Post, 26 November 2003.

${ }^{15}$ Richard Bernstein, "U.N. Atom Agency Seeks Wider Scrutiny of Iran, But is Rebuffed," New York Times, 20 June 2003.

${ }^{16}$ Glenn Kessler and Robin Wright, "U.S., Allies Agree on Iran Move," Washington Post, 25 November 2003.
} 
through traditional security concerns. This appears to have been the successful mix of carrots and sticks that convinced Libya to give up its weapons program. The interception of a major shipment of centrifuge parts bound for Libya in September of 2003, coupled with imaginative diplomacy in London-trading Libyan WMD disclosure for the prospect of opening the door to massive foreign investment-seems to have convinced Colonel Gaddafi that the pursuit of nuclear weapons was more trouble than it was worth. ${ }^{17}$ As an undoubtedly desirable outcome, the international community should make every effort to showcase Libya as a role model, encouraging economic ties and friendly relations, ideally with states like North Korea, Iran, and Syria taking note.

The troubling reality is that Libya is probably the exception rather than the rule, especially since Iran and North Korea appear to be much more advanced in their nuclear programs and thus will be less willing to part with them. In such cases, a more realistic target may be not the suspect state itself, but its primary supplier. The most disturbing aspect of the recent revelations regarding A.Q. Khan's nuclear dealing is how he was virtually the sole source of technology for nearly all of the world's suspected proliferators. ${ }^{18}$ While there might be some cause for optimism since it appears that Pakistan will shut down this nuclear clearinghouse, much of the damage may have already been done since designs and blueprints are not easily retrieved and cannot be unlearned. Even so, the knowledge that most of the nuclear advances that spark concern were not indigenously developed but were rather based on black market sales ought to reinvigorate interest in export controls since it demonstrates that effective

\footnotetext{
${ }^{17}$ Glenn Frankel, “A 'Long Slog' Led to Libya's Decision,” Washington Post, 21 December 2003; Robin Wright, "Ship Incident May Have Swayed Libya," Washington Post, 1 January 2004; Kenneth R. Timmerman, "Gadhafi's Mea Culpa on Arms, Terror," Washington Times, 4 March 2004; Daniel Williams, "Quick Change Suits Libyan Leader," Washington Post, 6 March 2004.

${ }^{18}$ Joby Warrick, "Nuclear Program in Iran Tied to Pakistan," Washington Post, 21 December 2003; Patrick E. Tyler and David E. Sanger, "Pakistan Called Libya's Source of Atom Design," New York Times, 6 January 2003; David Rohde and David E. Sanger, "Key Pakistani Said to Admit Atom Transfers," New York Times, 2 February 2004.
} 
nonproliferation efforts could have a substantial impact. This awareness should induce U.S. policymakers to increase funding for the Nunn-Lugar Cooperative Threat Reduction Program with the aim of ensuring that a Russian A.Q. Khan does not provide these states or other buyers with fissile material. ${ }^{19}$

Overall, there are two broad diplomatic approaches to combating the proliferation of WMD. First, in taking the diplomatic offensive, the United States must organize and lead a robust multilateral nonproliferation regime, perhaps built on the PSI and incorporating the IAEA and NATO. Given the gradual integration of Russia into the NATO structure, and the organization's expansion of membership into Eastern Europe, NATO is experiencing a self-definition crisis and is thus a prime candidate to refashion itself as a rapid-reaction anti-terror force. Fortunately, there are some indications that internal specialization along these lines is taking place, including the creation of a battalion trained for reconnaissance, WMD analysis, and decontamination. ${ }^{20}$ Ideally, an appropriate division of labor would have the PSI focusing on nonproliferation and interdiction, the IAEA being responsible for inspections, and NATO taking the lead on crisis management activities. No matter what, the crucial ingredient is to ensure that states with a high risk of proliferation activity that are not in NATO or the PSI-like Pakistan, China, and Russia-fully participate. This will certainly be a difficult diplomatic task, but based on a recently released Chinese white paper on nonproliferation, it appears that a prohibition against any form of transfer or assistance with WMD materials is becoming a widely accepted international norm. ${ }^{21}$ In time, these

\footnotetext{
${ }^{19}$ Nor is Russia the sole source of weapons grade uranium; see Joel Brinkley and William J. Broad, "U.S. Lags in Recovering Fuel Suitable for Nuclear Arms," New York Times, 7 March 2004.

${ }^{20}$ Nicholas Kralev, "NATO to Expand with New Focus on Terror Defense," Washington Times, 20 November 2002; Bruce I. Konviser, "NATO Plans Special Brigade to Fight Terror Risks," Washington Times, 5 February 2004.

${ }^{21}$ China, State Council Information Office White Paper, "China's Non-Proliferation Policy and Measures," December 2003. Available at http://news.xinhuanet.com/english/2003-12/03/content_1212032.htm. See also Edward Cody, "U.S.: China is Ally Against Proliferation," Washington Post, 17 February 2004 and
} 
organizations should have the capabilities and authority to back up their mandates with military force so that dictators cannot immunize their proliferation activities behind a false pretense of sovereignty. ${ }^{22}$ As with the Chinese white paper, a recent European Union statement of principles regarding proliferation states that a coercive form of disarmament "could be envisioned," lending hope that the global community is beginning to recognize its common vulnerability to WMD and conclude that tough cooperative initiatives are the only realistic response. ${ }^{23}$

To make this a reality, the United States must shift its strategic thinking away from unilateral supremacy and toward alliance predominance. One of the most frequently criticized sections of the National Security Strategy is the proclamation that the United States will not allow any strategic rivals to emerge: "Our forces will be strong enough to dissuade potential adversaries from pursuing a military build-up in hopes of surpassing, or equaling, the power of the United States." ${ }^{24}$ From a theoretical standpoint, this may be a natural desire of states, facing the inevitable uncertainties of a security dilemma within an anarchic international system and seeking to preserve a preeminent global position. ${ }^{25}$ However, given a brief survey of history—or, better yet, of China's growth rates-it is a profoundly optimistic and ultimately short-sighted strategy. Rather than rely on perpetual unipolarity, the United States should strive to create an entirely different balance of power based on like-minded regimes committed to protecting themselves against catastrophic WMD terrorism. The democratic and free states of the world must stay strong enough together to dissuade and defeat potential terrorist and

\footnotetext{
Robert Marquand, "China Brings Shift on Nukes to Korea Talks," Christian Science Monitor, 24 February 2004.

${ }^{22}$ For one vision along these lines, see Lee Feinstein and Anne-Marie Slaughter, "A Duty to Prevent," Foreign Affairs vol. 83, no. 1 (January/February 2004): 136-151.

${ }^{23}$ European Union, Basic Principles for an EU Strategy against Proliferation of Weapons of Mass Destruction, June 2003. Available at http://ue.eu.int/pressdata/EN/reports/76328.pdf.

${ }^{24}$ U.S. Government, National Security Strategy, 30.

${ }^{25}$ Michael Mastanduno, "Preserving the Unipolar Moment: Realist Theories and U.S. Grand Strategy After the Cold War," International Security vol. 21, no. 4 (spring 1997): 51 and 66; John J. Mearsheimer, The Tragedy of Great Power Politics (New York: W.W. Norton \& Company, 2001), 3.
} 
failed state challengers. Strangely enough, this very form of rhetoric is in the same NSS document: "The great strength of this nation must be used to promote a balance of power that favors freedom....America is now threatened less by conquering states than we are by failing ones." ${ }^{26}$ There is a profound disconnect between these two NSS statements, though, for the former implies that the United States remains fearful of conquering states, while the latter discounts such a threat.

In all likelihood, the real war the United States must win is one of values and ideals, with victory coming from the expansion and strengthening of peaceful relations. In this manner, America's second diplomatic approach is to lead a defensive strategy by targeting the demand side of the proliferation of WMD through an effort to promote regional security. Once again, the U.S. documents on strategic planning give special attention to this notion:

Together with the international community, we will wage a war of ideas to make clear that all acts of terrorism are illegitimate, to ensure that the conditions and ideologies that promote terrorism do not find fertile ground in any nation, to diminish the underlying conditions that terrorists seek to exploit in areas most at risk, and to kindle the hopes and aspirations of freedom of those in societies ruled by the sponsors of global terrorism. ${ }^{27}$

Yet, the question is whether this vision conforms to reality. Secretary of State Colin Powell has stressed the importance of partnerships in American strategy, noting in particular that the United States made a significant effort to bring its claims over Iraq to the UN Security Council. ${ }^{28}$ From the perspective of some other Council members, though, such consultation was mere pretext, with the United States convinced that war was necessary and the only matter open for discussion being which nations would participate in the coalition. In his defense, Powell also made a careful distinction

\footnotetext{
${ }^{26}$ U.S. Government, National Security Strategy, 1.

${ }^{27}$ U.S. Government, National Strategy for Combating Terrorism (Washington D.C.: February 2003), 23.

${ }^{28}$ Colin L. Powell, "A Strategy of Partnerships," Foreign Affairs vol. 83, no. 1 (January/February 2004): 25 .
} 
between working with other states toward common goals, and deferring to them for some kind of permission. International unanimity may be desirable, but the ultimate objective is a safer and more stable world, even if only a few like-minded states are willing to make the sacrifices for that to become a reality.

To win the war of ideas, the guiding principle of American grand strategy should be the empowerment of moderate elements in all societies, elevating those forces to a position where they can resolve regional security dilemmas and reduce the need and desire for WMD. The Arab-Israeli conflict serves as a painful and constant reminder that military force, no matter how overwhelming, cannot impose peace without a complementary spirit of compromise and fair settlement. Generally this process must be internally driven, though there are times when the good offices of neutral parties can be indispensable for breaking a deadlock and moving negotiations along. For instance, in a remarkably promising diplomatic breakthrough, UN Secretary General Kofi Annan has pledged an active role in moderating-and, if necessary, breaking stalemates-in reunification talks between Greek and Turkish Cypriot leaders. ${ }^{29}$ India and Pakistan have also shown renewed interest in reaching a settlement over Kashmir, partly spurred by international interest in tamping down nuclear tensions on the subcontinent. With every regional conflict that is brought closer to resolution, particularly in areas known for their propensity to cultivate terrorist factions, the world becomes that much safer and there are likely to be more states interested in the status quo and willing to rein in extremist elements. $^{30}$ Editorialist Thomas Friedman has written extensively on the link between poverty, war, and radicalism, claiming that the only way to defuse the antiAmerican terrorist threat is "by changing the context in which these young men grow up

\footnotetext{
${ }^{29}$ Warren Hoge, "Cyprus Greeks and Turks Agree on Plan to End 40-Year Conflict," New York Times, 14 February 2004.

${ }^{30}$ Robert S. Litwak, "Non-Proliferation and the Dilemmas of Regime Change," Survival vol. 45, no. 4 (winter 2003-04): 16.
} 
- namely all the Arab-Muslim states that are failing at modernity and have become an engine for producing undeterrables. ${ }^{31}$

The challenge is to translate a mission of transforming the global context of poverty and hatred into specific, concrete, and practical foreign policies. Democratization may be a desirable end goal, but the appropriate means toward that objective are very much in dispute. Iraq's struggle over how to establish a fair and balanced electoral system highlights the danger of pressing for democratic institutions before a population has accepted and internalized the principles behind them. Unfortunately, many states do not have the luxury of time to allow for measured deliberation and gradual reforms. Afghanistan, for instance, has presidential and parliamentary elections scheduled for June 2004, and it is uncertain whether President Hamid Karzai's fragile hold on power can prevent fundamentalist violence from marring the process. Although few would claim that Afghanistan is worse off than under Taliban-rule, the American investment of money and manpower has been relatively small, and what limited progress has taken place is mostly confined to the urban centers. ${ }^{32}$ As the United Nations initiates an Afghani voter drive in anticipation of the elections, it is essential that the United States provide strong financial and logistical backing. Especially in states that America defeats in war, when the U.S. reputation as a benign and peaceful superpower is on the line, the United States should liberally supply resources to make the defeated state a role model of its own. In the words of British Prime Minister Tony Blair: "How hollow would the charges of American imperialism be when these failed countries are and are seen to be transformed from states of terror to

\footnotetext{
${ }^{31}$ Thomas L. Friedman, "Iraq, Upside Down," New York Times, 18 September 2002.

${ }^{32}$ Michael Hirsh, "Bush and the World," Foreign Affairs vol. 81 no. 5 (September/October 2002): 24.
} 
nations of prosperity; from governments of dictatorship to examples of democracy; from sources of instability to beacons of calm?"33

The harsh reality is that there is a destructive imbalance in U.S. foreign policy; as the American military becomes ever more proficient at destroying adversaries and breaking down governments, the ability of the United States to cultivate allies and build up friendly regimes has atrophied. This is not to say that investment in "hard" military assets is imprudent, merely that a reallocation of resources may be in order under the guiding principle that an ounce of prevention is worth a pound of cure. ${ }^{34}$ With a defense budget of over $\$ 350$ billion in 2003 , it is difficult to understand why the United States chose to allocate only $\$ 25$ million for pilot programs to promote political, economic, and educational reforms in the Middle East. ${ }^{35}$ Troops posted in Germany to defend against a bygone Cold War threat are likely less important than teachers posted in Afghanistan to counterbalance the very current threat of fundamentalist schools, often providing the only available option for education and social services along with a strong element of anti-Americanism. Defense Secretary Rumsfeld appears to recognize the need to transform and modernize the U.S. military, but similar innovation is needed in areas like foreign aid, international trade, and cultural exchanges. ${ }^{36}$

As discussed in Chapter Six, encouraging engagement with adversaries can be a useful complement to a stern and uncompromising deterrence posture. Iran in particular has fallen into a black hole of American foreign policy, as it seems that U.S. leaders cannot agree on whether to soften a long-standing strategy of containment with more

\footnotetext{
${ }^{33}$ Tony Blair, Address to a Joint Session of Congress, Washington D.C., 17 July 2003.

${ }^{34}$ Lawrence Freedman, "Prevention, Not Preemption," The Washington Quarterly vol. 26, no. 2 (spring 2003): 114.

${ }^{35}$ Peter Slevin and Glenn Kessler, "U.S. to Seek Mideast Reforms," Washington Post, 21 August 2002.

${ }^{36}$ Donald H. Rumsfeld, "Defense for the $21{ }^{\text {st }}$ Century," Washington Post, 22 May 2003. The Bush Administration's Millennium Challenge Account will increase development aid substantially and target it toward liberalizing countries-a sensible first step; see Christopher Marquis, "New System Begins Rerouting U.S. Aid for Poor Countries," New York Times, 22 February 2004.
} 
friendly gestures. The devastating earthquake of late December 2003 in Bam provided the impetus for a humanitarian gesture on the part of the United States, which although ultimately rejected by Iran may still serve as a small first step toward talks and warmer relations. ${ }^{37}$ While suspicions over the Iranian nuclear program remain-many of them fully warranted ${ }^{38}$-there are also many heartening signs of the ascendancy of reform movements and a willingness to reach out to the United States in what Iranian President Mohammad Khatami termed a "dialogue of civilizations."39 The twin objectives of nonproliferation and liberalization may be competing in some ways, but they should not be seen as mutually exclusive. Iran is in the midst of an enormously important period of transition, as demonstrated by their tumultuous parliamentarian elections in February of 2004, and it is incumbent on the United States to support what Iranian expert Ray Takeyh terms the "mullahs in the middle." fair share of animosity toward the United States, which will be difficult to overcome, but there is no reason to expect that isolation and pressure tactics will increase the chances of Iranian nuclear forbearance; if anything, it will likely exacerbate their fears over security. In sum, America must balance its "hard" multinational nonproliferation regime with a "soft" campaign of promoting peace, stability, justice, and international cooperation. This strategy should involve efforts at nontraditional diplomacy, including

\footnotetext{
${ }^{37}$ Robin Wright, "U.S. Makes Overture to Iran," Washington Post, 2 January 2004; Karl Vick, "U.S. Talks Possible, Iranian Aide Says," Washington Post, 8 January 2004.

${ }^{38}$ Azadeh Moaveni, "Are Iran's Nuclear Promises Real?" Los Angeles Times, 21 November 2003; Joby Warrick, "Iranian Nuclear Plans Found," Washington Post, 13 February 2004; Peter Slevin and Joby Warrick, "U.N. Finds Uranium Enrichment Tools in Iraq," Washington Post, 20 February 2004; Karl Vick, "Another Nuclear Program Found in Iran," Washington Post, 24 February 2004; Craig S. Smith, "Alarm Raised Over Quality of Uranium Found in Iran," New York Times, 11 March 2004.

${ }^{39}$ Christopher de Bellaigue, "Iran's Last Chance for Reform?" The Washington Quarterly vol. 24, no. 4 (autumn 2001): 77. On Iran's reform movements and cooperation with the United States, see Geneive Abdo, "Iran's Generation of Outsiders," The Washington Quarterly vol. 24, no. 4 (autumn 2001): 163-171: Nazila Fathi, "Iranian Lawmaker Opens Door to American Talks," New York Times, 16 December 2002; Peter Slevin, "U.S. Met with Iranians on War," Washington Post, 9 February 2003; Neil MacFarquhar, "Student Protests in Tehran Become Nightly Fights for Freedom," New York Times, 14 June 2003; and Neil MacFarquhar, "A Khomeini Breaks With His Lineage to Back U.S.," New York Times, 6 August 2003.

${ }^{40}$ Ray Takeyh, "Re-imagining U.S.-Iranian Relations," Survival vol. 44, no. 3 (autumn 2002): 25.
} 
radio broadcasts that reach beyond a hostile government to its general population, or HIV/AIDS programs that seek to avoid a global medical catastrophe. ${ }^{41}$ It should also include innovative thinking on making nation-building more effective, such as the experimental "provincial reconstruction teams" deployed by NATO in Afghanistan to develop ties with local villages and tribal elders. ${ }^{42}$ Finally, it ought to embrace indirect mediation efforts (such as track-II diplomacy), using third parties to spur conciliation as on Cyprus or between the United States and North Korea. The common objective is a world that is more stable, friendlier toward the United States and its allies, and therefore generally safer to live in.

\section{Technology}

The twin elements that will determine the efficacy of global nonproliferation efforts are knowledge and capabilities. Even perfect unanimity and cooperation between countries will be useless if they lack timely and accurate information about a suspect WMD program or other potential threats. Likewise, stellar intelligence will be of little value if the assets needed to capitalize on it are wanting. With this in mind, the United States must invest in specialized counterproliferation technologies, aiming to undermine the foundation of a regional deterrent threat by being able to destroy it altogether or deflect its coercive power.

First and foremost, the United States needs to reform and strengthen its intelligence capabilities. The rising discontent over the apparently non-existent Iraqi

\footnotetext{
${ }^{41}$ Antony J. Blinken, "From Preemption to Engagement," Survival vol. 45, no. 4 (winter 2003-04): 48-50. Changing deeply ingrained perceptions of America will not be a simple task, as demonstrated by the reaction to a new Arabic television station run by the United States; see Neil MacFarquhar, "Washington's Arabic TV Effort Gets Mixed Reviews," New York Times, 20 February 2004.

${ }^{42}$ Eric Schmitt, "U.S. General Maps New Tactic to Pursue Taliban and Qaeda," New' York Times, 18 February 2004. American companies and civic organizations could "adopt" these Afghan villages and provide much needed supplemental support to the military teams; see Tom Brokaw, "How the Home Front Can Help," New York Times, 19 February 2004. For an employment-based nation-building strategy, see Ariana Eunjung Cha, "New U.S. Weapon: Jobs for Iraqi Men," Washington Post, 22 February 2004.
} 
WMD has led to over a half dozen investigations into the intelligence failures leading up to Iraqi Freedom. One recurring theme in these assessments is the urgent need for human sources to corroborate or deny defector reports and to pierce the veil of extensive systems of deception and disinformation. David Kay, the chief inspector in Iraq until January 2004, wrote a decade ago about the elaborate schemes WMD proliferators employ to hide evidence of their activities-techniques that appear to have improved over time. ${ }^{43}$ In fact, many observers now believe that Saddam Hussein may have had a double-deception program that sought to convince both the outside world and even his own military commanders that $\mathrm{CB}$ weapons existed when they actually did not. ${ }^{44}$ The difficulty is that gaining access to a well-placed spy is extraordinarily difficult in tribal regimes such as Saddam Hussein's Iraq, fundamentalist theocracies such as Khamenei's Iran, Al-Qaeda's compartmentalized terrorist cells, or totalitarian police-states like Kim Jong Il's North Korea. When direct espionage fails, a captured enemy prisoner can be an incredibly tempting source of insider knowledge (as apparently has been the case with some Al-Qaeda operatives ${ }^{45}$ ), setting off difficult moral dilemmas over the proper scope of coercive methods of interrogation. ${ }^{46}$ However, the United States can never be sure that it will be able to apprehend a senior adversary figure, and so it will have to rely on independent means of intelligence gathering. One crucial American advantage is its deep pockets and technological savvy. A tempting award can be remarkably motivating, as appears to have been the case in the search for Uday and Qusay Hussein. The United States also has revolutionized UAV technology, and coupling this with electronic

\footnotetext{
${ }^{43}$ David A. Kay, "Denial and Deception Practices of WMD Proliferators: Iraq and Beyond," The Washington Quarterly vol. 18, no. 1 (winter 1995): 85-105.

${ }^{44}$ Walter Pincus and Dana Priest, "Hussein's Weapons May Have Been Bluff," Washington Post, 1 October 2003; Nancy Gibbs and Michael Ware, "Chasing a Mirage," Time, 6 October 2003; Charles Krauthammer, "Calling Iraq's Bluff," Washington Post, 30 January 2004.

${ }^{45}$ Toni Locy and Kevin Johnson, "Suspect Helping U.S. Gauge Al-Qaeda's Arsenal," USA Today, 15 January 2003.

${ }^{46}$ Mark Bowden, "The Dark Art of Interrogation," The Atlantic Monthly vol. 292, no. 3 (October 2003): 51-76.
} 
eavesdropping devices should be quite effective. ${ }^{47}$ Against covert attack in particular, an advanced intelligence system is America's first and perhaps only line of defense, and should be prioritized accordingly. ${ }^{48}$

Relatedly, along with intelligence regarding WMD threats, the United States must develop country-specific knowledge, or "strategic profiles" as mentioned in Chapter Six. This is probably the most important area for further research, given that even America's vast resources are finite and will be spread thin without some selectivity over what states merit greater scrutiny. It will be far more efficient to separate out fundamentally defensively-oriented states for a strategy of containment-reserving more forceful, active measures for aggressive states and major proliferators. For instance, despite the advantage of hindsight, it is painfully clear how much easier it would have been to stem the black market trade in nuclear technology at its source in Pakistan (or, better yet, at its true point of origin in a Dutch nuclear facility with lax export controls) rather than expend financial and political capital to chase down its multiple endpoints. ${ }^{49}$ Not only will local knowledge be useful in identifying high-risk states, but it will also be a crucial component of gaining and sustaining world support should military action become necessary. ${ }^{50}$ The intelligence that supported Colin Powell's famous speech at the United Nations in February 2003 is now largely discredited, with correlative consequences for American credibility both in Iraq and beyond. ${ }^{51}$ The key realization is that adversary regimes are fluid and evolving entities - as most recently demonstrated by

\footnotetext{
${ }^{47}$ Noah Schactman, "A War of Robots, All Chattering on the Western Front," New York Times, 11 July 2002; Jonathan Finer, "A High-Tech Pilot Who Keeps His Feet on the Ground," Washington Post, 7 March 2003.

${ }^{48}$ William J. Perry, "Preparing for the Next Attack," Foreign Affairs vol. 80, issue 6 (November/December 2001): 36; Jason D. Ellis, "The Best Defense: Counterproliferation and U.S. National Security," The Washington Quarterly vol. 26, no. 2 (spring 2003): 126.

${ }^{49}$ William J. Broad, David E. Sanger, and Raymond Bonner, "A Tale of Nuclear Proliferation," New York Times, 12 February 2004.

${ }^{50}$ Bernard I. Finel, "The Role of Aerospace Power in U.S. Counterproliferation Strategy," Aerospace Power Journal (winter 1999): 86.

${ }^{51}$ Douglas Jehl and David E. Sanger, "Powell's Case A Year Later: Gaps in Picture of Iraq Arms," New York Times, 1 February 2004.
} 
Gaddafi's Libya ${ }^{52}$-and so the United States must both encourage reform and recognize which states are heading for trouble in order to properly allocate its scarce military and intelligence resources.

Finally, since past experience has shown that intelligence and diplomacy may fail, the United States must be able to win wars even against adversaries armed with WMD, and protect itself against their possible use. In many ways, offensive and defensive capabilities work in tandem to strengthen deterrence, causing an enemy to be uncertain that its threat will succeed and to be fearful of the retaliation that is sure to follow. Such calculations can be part of a delicate balance, as too great a preemptive threat may lead to a "use it or lose it" situation, but at times a threat to a leader's personal survival may provide much needed leverage in negotiations. ${ }^{53}$ Moreover, if war does break out and an adversary resorts to WMD, the United States will need to be able to destroy any remaining stockpiles or facilities. As discussed in Chapter Four, there are numerous counterforce innovations on the drawing board to achieve this mission, ranging from attack drones to immobilizing foams and microwave weapons. ${ }^{54}$ The U.S. military is also reopening research into so-called mini-nukes, though there are enormous doubts about their practical use and concerns over their political consequences. More appropriate is a drive toward conventional solutions by forging partnerships with private companies and international experts conducting cutting-edge research. ${ }^{55}$ The United

\footnotetext{
${ }^{52}$ Scott Anderson, "The Makeover," New York Times Magazine, 19 January 2003.

${ }^{53}$ Thom Shanker, "Lessons from Iraq Include How to Scare North Korean Leader," New York Times, 12 May 2003.

${ }^{54}$ Special operations forces will likely have a unique role in carrying out this task, given the clear premium on speed and stealth. See Michael Evans, "SAS Plan to Blow Up Saddam's Germ Sites," London Times, 12 July 2002.

${ }^{55}$ For example, see William J. Broad, "Sleuths Patrol Nations for Nuclear Mischief," New York Times, 30 December 2003.
} 
States is not prepared defensively, ${ }^{56}$ and so rather than build new nuclear weapons, it should direct its scientific talent toward tracking and detecting them. ${ }^{57}$

\section{Conclusion}

Diplomatic and technological strategies are really two sides of the same coin; international collaboration is critical to scientific research into new means of intelligence gathering, and advanced inspections capabilities are indispensable to global nonproliferation efforts. The spread of WMD is a common threat, and it must be met with united resolve. Yet, the United States feels a unique vulnerability stemming from its superpower status and active role in foreign affairs. The menace of terrorism is particularly salient to Americans in the wake of 11 September 2001, and there is an understandable urge to take to the warpath, embodied in Secretary Rumsfeld's mantra that "the best—and, in some cases, the only—defense is a good offense" and Deputy Defense Secretary Wolfowitz's conclusion that "the only defense against terrorism is to take war to the enemy." 58 These statements resonate because with the destructive potential of WMD, and the growing reservations over deterrence, there is a feeling that "no place will be safe until every place is made safe." 59 There may be an underlying truth to this belief, but it does not follow that war-preemptive or otherwise-is the appropriate means toward that end. The United States cannot conquer every state that poses a threat, and there is simply no way to uncover weapons that can be hidden even in private homes.

\footnotetext{
${ }^{56}$ Shaun Waterman, "Test Reveals Wide Failures in Terror Response Abilities," Washington Times, 21 December 2003; Vernon Loeb, "Biodefense Agency Urged for Safety of U.S. Troops," Washington Post, 23 January 2004.

${ }^{57}$ Graham Allison, "How to Stop Nuclear Terror," Foreign Affairs vol. 83, no. 1 (January/February 2004): 64-74.

${ }^{58}$ Donald H. Rumsfeld, Speech on $21^{\text {st }}$ Century Transformation of the U.S. Armed Forces, National Defense University, Washington D.C., 31 January 2002; Paul Wolfowitz, Remarks at the $38^{\text {th }}$ Munich Conference on Security Policy, Munich, Germany, 2 February 2002.

${ }^{59}$ William E. Burrows and Robert Windrem, Critical Mass: The Dangerous Race for Superweapons in a Fragmenting World (London: Simon \& Schuster Ltd., 1994), 21 (emphasis added).
} 
I began this dissertation by focusing on the increasing power of rogue state WMD threats, predicting that the United States will be deterred from intervening in regional conflicts. Recognizing the shortcomings of containment in a security environment with little warning of attack, I urged the creation of a multilateral nonproliferation regime that would establish WMD standards for the world and regulate them by force if need be. To temper this offensively oriented institution, I also recommended a strategy of engagement with the world to support and nurture moderate regimes. To return once more to the "chicken" analogy, it will be necessary, especially in the Middle East and Central Asia, for the United States to undertake nontraditional missions such as nation building, peacekeeping, and-in the case of Israel and Palestine-peacemaking to try and minimize the number of disgruntled drivers on the road looking for a challenge. In the long-run, the spread of WMD technology is inevitable, and so the best hope for the future lies in promoting peace since there is simply no surefire defense or offense against suicide bombers and the eventual prospect of suicide states. Ultimately, the United States must have the capabilities to deter and defeat its adversaries when it really counts, but it must also work to create an international environment where it has to roll the dice of deterrence as few times as possible. The game is as dangerous as they come, so one should know the other players and choose opponents wisely. 


\section{Bibliography: Works Cited}

\section{$\underline{\text { Books/Articles }}$}

Abdo, Geneive. "Iran's Generation of Outsiders." The Washington Quarterly vol. 24, no. 4 (autumn 2001): 163-171.

Abrams, Eliot, ed. Close Calls: Intervention, Terrorism, Missile Defense, and 'Just War' Today. Washington D.C.: Ethics and Public Policy Center, 1998.

Aburish, Said K. Saddam Hussein, The Politics of Revenge. London: Bloomsbury, 2000. Ackerman, Gary and Laura Snyder. "Would They if They Could?" Bulletin of the Atomic Scientists (May/June 2002): 41-47.

Albright, David. “A Proliferation Primer." The Bulletin of Atomic Scientists vol. 49, no. 5 (June 1993): 14-23.

Alexandrov, Stanimir A. Self-Defense Against the Use of Force in International Law. Cambridge, MA: Kluwer Law International, 1996.

Allison, Graham. "How to Stop Nuclear Terror." Foreign Affairs vol. 83, no. 1 (January/February 2004): 64-74.

Arend, Anthony Clark. "International Law and the Preemptive Use of Military Force." The Washington Quarterly vol. 26, no. 2 (spring 2003): 89-103.

Arend, Anthony Clark and Robert J. Beck. International Law and the Use of Force: Beyond the UN Charter Paradigm. London: Routledge, 1993.

Arkin, William M. "Calculated Ambiguity: Nuclear Weapons and the Gulf War." The Washington Quarterly vol. 19, no. 4 (autumn 1996): 3-18.

Arquilla, John. "Bound to Fail: Regional Deterrence after the Cold War." Comparative Strategy vol. 14, no. 2 (April-June 1995): 123-135.

Art, Robert J. and Patrick M. Cronin, eds. The United States and Coercive Diplomacy. 
Washington D.C.: United States Institute of Peace Press, 2003.

Art, Robert J. and Kenneth N. Waltz, eds. The Use of Force: Military Power and International Relations, $5^{\text {th }}$ Edition. Maryland: Rowland \& Littlefield, 1999.

- The Use of Force: Military Power and International Relations, $4^{\text {th }}$ edition. Lanham, MD: University Press of America, 1993.

Atkinson, Rick. Crusade: The Untold Story of the Gulf War. London: Harper Collins Publishers, 1994.

Bailey, Kathleen C. Doomsday Weapons in the Hands of Many: The Arms Control Challenge of the 90s. Chicago: University of Ilinois Press, 1991.

Baker, James A. III, with Thomas M. DeFrank. The Politics of Diplomacy. New York: G.P. Putnam's Sons, 1995.

Baram, Amatzia. "Saddam Husayn: Between His Power Base and the International Community." Middle East Review of International Affairs vol. 4, no. 4 (December 2000): 9-21.

Baram, Amatzia and Barry Rubin, eds. Iraq's Road to War. London: Macmillan Press, 1994.

Barletta, Michael. "Chemical Weapons in the Sudan: Allegations and Evidence." Nonproliferation Review vol. VI, no. 1 (fall 1998): 115-136.

de Bellaigue, Christopher. “Iran's Last Chance for Reform?” The Washington Quarterly vol. 24, no. 4 (autumn 2001): 71-80.

Bengio, Ofra. Saddam's World: Political Discourse in Iraq. New York: Oxford University Press, 1998.

Bermudez, Joseph S. Jr. The Armed Forces of North Korea. New York: I.B. Tauris \& Co Ltd., 2001.

_ . 'Exposing North Korea's Secret Nuclear Infrastructure-Part Two.” Jane's 
Intelligence Review vol. 11, no. 8 (August 1999): 41-45.

—_. "The Rise and Rise of North Korea's ICBMs." Jane's International Defense Review vol. 32, no. 7 (1 July 1999).

Bertram, Christoph, ed. Strategic Deterrence in a Changing Environment. London: International Institute for Strategic Studies, 1981.

Betts, Richard. “Suicide From Fear of Death?” Foreign Affairs vol. 82, no. 1 (January/February 2003): 34-43.

—. "The New Threat of Mass Destruction." Foreign Affairs vol. 77, no. 1 (January/February 1998): 26-41.

—. "What Will it Take to Deter the United States?" Parameters vol. XXI, no. 4 (winter 1995-96): 70-79.

—. Nuclear Blackmail and Nuclear Balance. Washington D.C.: Brookings Institution, 1987.

Blackwill, Robert D. and Albert Carnesale, eds. New Nuclear Nations: Consequences for U.S. Policy. New York: Council on Foreign Relations Press, 1993.

Blight, James G. and David A. Welch, "Risking 'the Destruction of Nations:' Lessons of the Cuban Missile Crisis for New and Aspiring Nuclear States." Security Studies vol. 4 , no. 4 (summer 1995): 811-850.

Blinken, Antony J. "From Preemption to Engagement." Survival vol. 45, no. 4 (winter 2003-04): 33-60.

Blum, William. Rogue State: A Guide to the World's Only Superpower. London: Zed Books, 2001.

Boniface, Pascal. "What Justifies Regime Change?” The Washington Quarterly vol. 26, no. 3 (summer 2003): 61-71.

Booth, Ken. Strategy and Ethnocentrism. London: Croom Helm Ltd., 1979. 
Bowden, Mark. "The Dark Art of Interrogation." The Atlantic Monthly vol. 292, no. 3 (October 2003): 51-76.

Bowett, Derek W. Self-Defence in International Law. Manchester: The University Press, 1958.

Bracken, Paul. Fire in the East: The Rise of Asian Military Power and the Second Nuclear Age. New York: Harper Collins Publishers, 1999.

Brinkley, Douglas. The Unfinished Presidency. New York: Penguin Putnam, 1998.

Brodie, Bernard. Strategy in the Missile Age. Princeton, NJ: Princeton University Press, 1959.

The Absolute Weapon: Atomic Power and World Order. New York: Harcourt, 1946.

Brownlie, Ian. International Law and the Use of Force By States. Oxford: Oxford University Press, 1963.

Bueno de Mesquita, Bruce and William H. Riker. "Selective Nuclear Proliferation." Journal of Conflict Resolution vol. 26, no. 2 (June 1982): 283-306.

Buhite, Russell D. and William Christopher Hamel. "War for Peace: The Question of an American Preventive War Against the Soviet Union, 1945-1955.” Diplomatic History vol. 14, no. 3 (Summer 1990): 367-84.

Bull, Hedley. The Anarchical Society, $2^{\text {nd }}$ Edition. London: Macmillan Press Ltd., 1995. Burr, William and Jeffrey T. Richelson. "Whether to 'Strangle the Baby in the Cradle:' the United States and the Chinese Nuclear Program, 1960-64." International Security vol. 25, no. 3 (winter 2000-01): 54-99.

Burrows, William E. and Robert Windrem. Critical Mass: The Dangerous Race for Superweapons in a Fragmenting World. London: Simon \& Schuster Ltd., 1994. Bush, George and Brent Scowcroft. A World Transformed. New York: Alfred A. Knopf, 
1998.

Byman, Daniel, Kenneth Pollack, and Matthew Waxman. "Coercing Saddam Hussein: Lessons from the Past." Survival vol. 40, no. 3 (autumn 1998): 127-152.

Cain, Anthony C. Iran's Strategic Culture and Weapons of Mass Destruction, Maxwell Paper No. 26. Maxwell Air Force Base, AL: Air War College, April 2002.

Carter, Ashton B. “The Korean Nuclear Crisis." Harvard Magazine vol. 106, no. 1 (September/October 2003): 38-41.

Carter, Ashton B. and William J. Perry. Preventive Defense: A New Security Strategy for America. Washington D.C.: Brookings Institution Press, 1999.

Cha, Victor D. “North Korea's Weapons of Mass Destruction: Badges, Shields, or Swords?” Political Science Quarterly vol. 117, no. 2 (summer 2002): 209-230.

—. "Hawk Engagement and Preventive Defense on the Korean Peninsula." International Security vol. 27, no. 1 (summer 2002): 40-78.

—. "The Second Nuclear Age: Proliferation Pessimism Versus Sober Optimism in South Asia and East Asia." Journal of Strategic Studies vol. 24, no. 4 (December 2001): 79-120.

Cha, Victor D. and David C. Kang. Nuclear North Korea: A Debate on Engagement Strategies. New York: Columbia University Press, 2003.

Chandler, Robert W., with Ronald J. Trees. Tomorrow's War, Today's Decisions: Iraqi Weapons of Mass Destruction and the Implications of WMD-Armed Adversaries for Future U.S. Military Strategy. McLean, VA: AMCODA Press, 1996.

Chol, Kim Myong. “Kim Jong Il’s Military Strategy for Reunification.” Comparative Strategy vol. 20 (2001): 303-420.

Chubin, Shahram. Whither Iran? Reform, Domestic Politics and National Security, Adelphi Paper No. 342. Oxford: Oxford University Press, International Institute 
for Strategic Studies, 2002.

—. "Does Iran Want Nuclear Weapons?" Survival vol. 37, no. 1 (spring 1995): 86104.

- Iran's National Security Policy: Intentions, Capabilities, \& Impact. Washington D.C.: Carnegie Endowment for International Peace, 1994.

Cimbala, Stephen J. Nuclear Strategy in the Twenty-First Century. Westport, CT: Praeger Publishers, 2000.

The Past and Future of Nuclear Deterrence. Westport, CT: Praeger Publishers, 1998.

Cirincione, Joseph, with John B. Wolfsthal and Miriam Rajkumar. Deadly Arsenals:

Tracking Weapons of Mass Destruction. Washington D.C.: Carnegie Endowment for International Peace, June 2002.

Cockburn, Andrew and Patrick Cockburn. Out of the Ashes: The Resurrection of Saddam Hussein. London: Verso, 2000.

Cohen, Yohanan. Small Nations in Times of Crisis and Confrontation. Albany, NY: State University of New York Press, 1989.

Cole, Leonard A. The Eleventh Plague: The Politics of Biological and Chemical Warfare. New York: W.H. Freeman and Company, 1997.

Cordesman, Anthony H. Iran's Military Forces in Transition: Conventional Threats and Weapons of Mass Destruction. Westport, CT: Praeger Publishers, 1999.

Coughlin, Con. Saddam: The Secret Life. London: Macmillan, 2002.

Craig, Gordon A. and Alexander L. George. Force and Statecraft: Diplomatic Problems of Our Time, $3^{\text {rd }}$ Edition. Oxford: Oxford University Press, 1995.

Crawford, Natalie W. and Chung-in Moon, eds. Emerging Threats, Force Structures, and the Role of Air Power in Korea. Santa Monica, CA: RAND, 2000. 
Critchlow, Robert D. "Whom the Gods Would Destroy: An Information Warfare

Alternative for Deterrence and Compellence." Naval War College Review vol. LIII, no. 3 (summer 2000): 21-38.

Cummings, Bruce. Korea's Place in the Sun. New York: W.W. Norton \& Company, 1997.

Darwish, Adel and Gregory Alexander. Unholy Babylon: The Secret History of Saddam's War. London: Victor Gollancz Ltd., 1991.

David, Steven R. "Risky Business: Let Us Not Take a Chance on Proliferation." Security Studies vol. 4, no. 4 (summer 1995): 773-778.

Davis, Jim A. and Barry R. Schneider, eds. The Gathering Biological Warfare Storm. Maxwell Air Force Base, AL: USAF Counterproliferation Center, April 2002. Dougherty, James E. and J.F. Lehman Jr., eds. Arms Control for the Late Sixties.

Canada: D. Van Nostrand Company, Inc., 1967.

Dowdy, William L. and Barry R. Schneider. "On to Baghdad? Or Stop at Kuwait? A Gulf War Question Revisited." Defense Analysis vol. 13, no. 3 (December 1997): 319-329.

Dowler, Thomas M. and Joseph S. Howard II. "Stability in a Proliferated World." Strategic Review vol. XXIII, no. 2 (spring 1995): 26-37.

Downs, Chuck. Over the Line: North Korea's Negotiating Strategy. Washington D.C.: AEI Press, 1999.

Dunn, Lewis A. "Rethinking the Nuclear Equation: The United States and the New Nuclear Powers." The Washington Quarterly vol. 17, no. 1 (winter 1994): 5-25.

- Containing Nuclear Proliferation, Adelphi Paper No. 263. London:

International Institute for Strategic Studies, winter 1991.

- Controlling the Bomb: Nuclear Proliferation in the 1980s. New Haven, CT: 
Yale University Press, 1982.

Dror, Yehezkel. Crazy States: A Counterconventional Strategic Problem. Lexington, MA: Heath Lexington Books, 1971.

Edwards, A.J.C. Nuclear Weapons, the Balance of Terror, the Quest for Peace. London: Macmillan Press Ltd., 1986.

Ellis, Jason D. "The Best Defense: Counterproliferation and U.S. National Security." The Washington Quarterly vol. 26 no. 2 (spring 2003): 115-133.

Falkenrath, Richard A., Robert D. Newman, and Bradley A. Thayer. America's Achilles' Heel: Nuclear, Biological, and Chemical Terrorism and Covert Attack.

Cambridge, MA: MIT Press, 1998.

Feaver, Peter D. "Proliferation Optimism and Theories of Nuclear Operations." Security Studies vol. 2, nos. 3 and 4 (spring/summer 1993): 159-191.

Feinstein, Lee and Anne-Marie Slaughter. "A Duty to Prevent." Foreign Affairs vol. 83, no. 1 (January/February 2004): 136-151.

Feldman, Shai. “The Bombing of Osiraq-Revisited.” International Security vol. 7, no. 2 (fall 1982): 114-142.

Fest, Joachim. Speer: The Final Verdict. London: Phoenix Press, 1999.

Finel, Bernard I. "The Role of Aerospace Power in U.S. Counterproliferation Strategy." Aerospace Power Journal (winter 1999): 77-89.

Frank, Jerome D. Sanity and Survival: Psychological Aspects of War and Peace. London: The Cresset Press, 1967.

Freedman, Benjamin. The Proliferation Security Initiative: The Legal Challenge, Policy Brief. Washington D.C.: Bipartisan Security Group, September 2003.

Freedman, Lawrence. "Prevention, Not Preemption." The Washington Quarterly vol. 26, no. 2 (spring 2003): 105-114. 
-., ed. Strategic Coercion: Concepts and Cases. Oxford: Oxford University Press, 1998.

-The Evolution of Nuclear Strategy, $2^{\text {nd }}$ Edition. London: Macmillan Press Ltd., in association with the International Institute of Strategic Studies, 1989.

Freedman, Lawrence and Efraim Karsh. The Gulf Conflict 1990-1991: Diplomacy and War in the New World Order. London: Faber and Faber, 1993.

—. "How Kuwait Was Won: Strategy in the Gulf War." International Security vol. 16, no. 2 (fall 1991): 5-41.

Gallois, Pierre. The Balance of Terror: Strategy for the Nuclear Age. Boston, MA: Houghton Mifflin Company, 1961.

Garnham, David. Deterrence Essentials: Keys to Controlling an Adversary's Behavior. Abu Dhabi: Emirates Center for Strategic Studies and Research, 1995.

Garwin, Richard L. "A Defense That Will Not Defend." The Washington Quarterly vol. 23, no. 3 (summer 2000): 109-123.

Gelman, Harry. The Soviet Far East Buildup and Soviet Risk-Taking Against China. Santa Monica, CA: RAND, August 1982.

George, Alexander L. and Richard Smoke. Deterrence in American Foreign Policy: Theory and Practice. New York: Columbia University Press, 1974.

Glaser, Charles L. and Steve Fetter. "National Missile Defense and the Future of U.S. Nuclear Weapons Policy." International Security vol. 26, no. 1 (summer 2001): 40-92.

Glennon, Michael J. “The Fog of War: Self-Defense, Inherence, and Incoherence in Article 51 of the United Nations Charter." Harvard Journal of Law and Public Policy vol. 25, no. 2 (spring 2002): 539-558.

Glosson, Buster. War with Iraq: Critical Lessons. Charlotte, NC: Glosson Family 
Foundation, 2003.

Goldstein, Avery. Deterrence and Security in the $21^{\text {st }}$ Century: China, Britain, France, and the Enduring Legacy of the Nuclear Revolution. Stanford, CA: Stanford University Press, 2000.

Goldstein, Lyle J. "Do Nascent WMD Arsenals Deter? The Sino-Soviet Crisis of 1969.” Political Science Quarterly vol. 118, no. 1 (spring 2003): 53-79.

Gordon, Michael R. and Bernard E. Trainor. The General's War. New York: Little, Brown and Company, 1995.

Gordon, Philip. "Bush, Missile Defence, and the Atlantic Alliance.” Survival vol. 43, no. 1 (spring 2001): 17-36.

Gray, Christine. International Law and the Use of Force. Oxford: Oxford University Press, 2000.

Gray, Colin S. The Second Nuclear Age. London: Lynne Rienner Publishers, Inc., 1999.

Grimmett, Richard F. "U.S. Use of Preemptive Military Force." Congressional Research Service, 18 September 2002.

Hadley, Stephen J. “A Call to Deploy.” The Washington Quarterly vol. 23, no. 3 (summer 2000): 95-108.

Hagerty, Devin T. "Nuclear Deterrence in South Asia: the 1990 Indo-Pakistani Crisis." International Security vol. 20, no. 3 (winter 1995-96): 79-114.

Halperin, Morton. Limited War in the Nuclear Age. Westport, CT: Greenwood Press, 1963.

Harrison, Selig S. Korean Endgame: A Strategy for Reunification and U.S. Disengagement. Princeton, NJ: Princeton University Press, 2002.

Hart, Gary and Warren B. Rudman. Co-Chairs of Council on Foreign Relations Task Force, America Still Unprepared-America Still in Danger. 17 October 2002. 
Haselkorn, Avigdor. “Iraq's Bio-Warfare Option: Last Resort, Preemption, or a Blackmail Weapon?" Biosecurity and Bioterrorism: Biodefense Strategy, Practice, and Science vol. 1, no. 1 (2003): 19-26.

- The Continuing Storm: Iraq, Poisonous Weapons, and Deterrence. New Haven, CT: Yale University Press, 1999.

Heisbourg, Francois. “A Work in Progress: The Bush Doctrine and Its Consequences.” The Washington Quarterly vol. 26, no. 2 (spring 2003): 75-88.

Henkin, Louis. How Nations Behave: Law and Foreign Policy, $2^{\text {nd }}$ Edition. New York: Columbia University Press, 1979.

Herring, Eric. "Rogue Rage: Can We Prevent Mass Destruction?” Journal of Strategic Studies vol. 23, no. 1 (March 2000): 188-212.

Hersh, Seymour M. The Samson Option: Israel, America and the Bomb. London: Faber, 1991.

Hiro, Dilip. Desert Shield to Desert Storm: The Second Gulf War. New York: Routledge, 1992.

- The Longest War: The Iran-Iraq Military Conflict. New York: Routledge, 1991.

Hirsh, Michael. "Bush and the World." Foreign Affairs vol. 81 no. 5 (September/October 2002): $18-43$.

Hodge, Homer T. "North Korea's Military Strategy.” Parameters vol. XXXII, no. 1 (spring 2003): 68-81.

Huntington, Samuel. “The Lonely Superpower.” Foreign Affairs vol. 78, no. 2 (March/April 1999): 35-49.

—. "Why International Primacy Matters." International Security vol. 17, no. 4 (spring 1993): 68-83.

Ikenberry, G. John. “America's Imperial Ambition.” Foreign Affairs vol. 81, no. 5 
(September/October 2002): 44-60.

Iklé, Fred Charles. "Can Nuclear Deterrence Last Out the Century?" Foreign Affairs vol. 51, no. 2 (January 1973): 267-285.

Inbar, Efraim, ed. Regional Security Regimes. Albany, NY: State University of New York Press, 1995.

James, Robert Rhodes, ed. Winston S. Churchill: His Complete Speeches, 1897-1963, vol. 6. New York: Chelsea House Publishers, 1974.

Janis, Irving L. and Leon Mann. Decision Making: A Psychological Analysis of Conflict. New York: The Free Press, 1977.

Jenkins, Brian M. “Will Terrorists Go Nuclear?” Orbis vol. 29, no. 3 (fall 1985): 507515.

Jennings, R.Y. "The Caroline and McLeod Cases." The American Journal of International Law vol. 32, no. 2 (April 1938): 82-99.

Jervis, Robert. The Illogic of American Nuclear Strategy. Ithaca, NY: Cornell University Press, 1984.

—. "Deterrence and Perception." International Security vol. 7, no. 3 (winter 198283): 3-30.

—. "Why Nuclear Superiority Doesn't Matter." Political Science Quarterly vol. 94, no. 4 (winter 1979-80): 617-633.

- Perception and Misperception in International Politics. Princeton, NJ: Princeton University Press, 1976.

Jervis, Robert, Richard Ned Lebow, and Janice Gross Stein, eds. Psychology and Deterrence. Baltimore, MD: Johns Hopkins University Press, 1985.

Jodoin, Vincent J. and Alan R. Van Tassel, eds. Countering the Proliferation and Use of Weapons of Mass Destruction. New York: McGraw-Hill, 1998. 
Johnson, Steven. “Stopping Loose Nukes.” Wired vol. 10, no. 11 (November 2002).

Johnson, Stuart E., ed. The Niche Threat: Deterring the Use of Chemical and Biological Weapons. Washington D.C.: National Defense University Press, 1997.

Jones, Rodney M., ed. Small Nuclear Forces and U.S. Security Policy. Washington, D.C.: Center for Strategic and International Studies, 1984.

Joseph, Robert G. "Regional Implications of NBC Proliferation." Joint Forces Quarterly no. 9 (autumn 1995): 64-69.

Joseph, Robert G. and John F. Reichart. Deterrence and Defense in a Nuclear, Biological, and Chemical Environment. Washington D.C.: National Defense University Press, 1999.

Kagan, Donald. On the Origins of War and the Preservation of Peace. New York: Doubleday, 1995.

Kahn, Herman. On Thermonuclear War. Princeton, NJ: Princeton University Press, 1969.

- Thinking About the Unthinkable. London: Weidenfeld and Nicolson, 1962.

Kaplan, Morton A. System and Process in International Politics. New York: John Wiley \& Sons, Inc., 1957.

Karsh, Efraim and Inari Rautsi. Saddam Hussein: A Political Biography. London: Brassey's, 1991.

Katzman, Kenneth. The Warriors of Islam: Iran's Revolutionary Guard. Oxford: Westview Press, Inc., 1993.

Kay, David. "Denial and Deception Practices of WMD Proliferators: Iraq and Beyond." The Washington Quarterly vol. 18, no. 1 (winter 1995): 85-105.

Keeny, Spurgeon M. Jr. and Wolfgang K. H. Panofsky. "MAD Versus NUTS: Can Doctrine or Weaponry Remedy the Mutual Hostage Relationship of the 
Superpowers?" Foreign Affairs vol. 60, no. 2 (winter 1981-82): 287-304.

Khong, Yuen Foong. "Vietnam, the Gulf, and U.S. Choices: A Comparison." Security Studies vol. 2, no. 1 (autumn 1992): 74-95.

Kim, Kyoung-Soo. "North Korea's CB Weapons: Threat and Capability." The Korean Journal of Defense Analysis vol. XIV, no. 1 (spring 2002): 69-95.

Kim, Samuel S., ed. The North Korean System in the Post-Cold War Era. New York: Palgrave, 2001.

Kissinger, Henry. Does America Need a Foreign Policy? New York: Simon \& Schuster, 2001.

- Nuclear Weapons and Foreign Policy. New York: Harper \& Brothers, 1957.

Kiziah, Rex R. Assessment of the Emerging Biocruise Threat, Future Warfare Series No.

6. Maxwell Air Force Base, AL: Air War College, August 2000.

Knorr, Klaus. The Power of Nations: The Political Economy of International Relations. New York: Basic Books, Inc., 1975.

Krauthammer, Charles. “The Unipolar Moment.” Foreign Affairs vol. 70, no. 1 (1990-91): 23-33.

Krepon, Michael. “Moving Away from MAD.” Survival vol. 43, no. 2 (summer 2001): 81-95.

Kristensen, Hans M. Nuclear Futures: Proliferation of Weapons of Mass Destruction and U.S. Nuclear Strategy. London: British American Security Information Council, March 1998.

Laney, James T. and Jason T. Shaplen. "How to Deal with North Korea." Foreign Affairs vol. 82, no. 2 (March/April 2003):16-30.

Lavoy, Peter R. "The Strategic Consequences of Nuclear Proliferation: A Review Essay." Security Studies vol. 4, no. 4 (summer 1995): 695-753. 
Lavoy, Peter R., Scott D. Sagan, and James J. Wirtz, eds. Planning the Unthinkable: How New Powers Will Use Nuclear, Biological, and Chemical Weapons. Ithaca, NY: Cornell University Press, 2000.

Law, Alfred D. The Sino-Soviet Dispute. London: Associated University Presses, 1976. Lebovic, James H. "The Law of Small Numbers: Deterrence and National Missile Defense." The Journal of Conflict Resolution vol. 46, no. 4 (August 2002): 455483.

Lebow, Richard Ned. Between Peace and War: The Nature of International Crisis. Baltimore, MD: Johns Hopkins University Press, 1981.

Lebow, Richard Ned and Janice Gross Stein. "Beyond Deterrence.” Journal of Social Issues vol. 43, no. 4 (1987): 5-71.

Lederberg, Joshua, ed. Biological Weapons: Limiting the Threat. Cambridge, MA: The MIT Press, 1999.

Lee, Jung-Hoon and Il Hyun Cho. "The North Korean Missiles: A Military Threat or a Survival Kit?" The Korean Journal of Defense Analysis vol. XII, no. 1 (summer 2000): $131-154$.

Levi, Michael A. Fire in the Hole: Nuclear and Non-Nuclear Options for Counterproliferation, Working Paper No. 31. Washington D.C.: Carnegie Endowment for International Peace, November 2002.

Levy, Jack S. and Joseph R. Gochal. "Democracy and Preventive War: Israel and the 1956 Sinai Campaign.” Security Studies vol. 11, no. 2 (winter 2001-02): 1-49.

Lewis, George, Lisbeth Gronlund, and David Wright. "National Missile Defense: An Indefensible System.” Foreign Policy no. 117 (winter 1999-2000): 120-137.

Lieberman, Elli. Deterrence Theory: Success or Failure in Arab-Israeli Wars? McNair Paper No. 45. Washington D.C.: Institute for National Strategic Studies, National 
Defense University, October 1995.

Lindsay, James M. and Michael E. O’Hanlon. “Correspondence.” International Security vol. 26, no. 4 (spring 2002): 190-201.

- Defending America: The Case for Limited National Missile Defense.

Washington D.C.: Brookings Institution Press, 2001.

Litwak, Robert S. "Non-Proliferation and the Dilemmas of Regime Change." Survival vol. 45 , no. 4 (winter 2003-04): 7-32.

—. "The New Calculus of Pre-emption." Survival vol. 44, no. 4 (winter 2002-03): 53-80.

- Rogue States and U.S. Foreign Policy: Containment after the Cold War. Baltimore, MD: Johns Hopkins University Press, 2000.

Lodal, Jan. The Price of Dominance: The New Weapons of Mass Destruction and Their Challenge to American Leadership. New York: Council of Foreign Relations, 2001.

Luttwak, Edward and Dan Horowitz. The Israeli Army. London: Penguin Books Ltd., 1975.

Mack, Andrew. "A Nuclear North Korea.” World Policy Journal vol. XI, no. 2 (summer 1994): $27-35$.

—_ "Why Big Nations Lose Small Wars: the Politics of Asymmetric Conflict." World Politics vol. XXVII, no. 2 (January 1975): 175-200.

Mahnken, Thomas G. “America's Next War.” The Washington Quarterly vol. 16, no. 3 (summer 1993): 171-184.

Manning, Robert A. "The Enigma of the North." The Washington Quarterly vol. 23, no. 3 (summer 1999): 72-80.

Manwaring, Max G., ed. Deterrence in the $21^{\text {st }}$ Century. London: Frank Cass \& Co., 
Ltd., 2001.

Mastanduno, Michael. "Preserving the Unipolar Moment: Realist Theories and U.S.

Grand Strategy After the Cold War." International Security vol. 21, no. 4 (spring 1997): 49-88.

Maxon, Richard G. "Nature's Eldest Law: A Survey of a Nation's Right to Act in SelfDefense.” Parameters vol. XXV, no. 3 (autumn 1995): 55-68.

Maxwell, Stephen. Rationality in Deterrence, Adelphi Paper No. 50. London:

International Institute for Strategic Studies, 1968.

May, Michael M. and Zachary Haldeman. Effectiveness of Nuclear Weapons Against Buried Biological Agents. Stanford, CA: Center for International Security and Cooperation, June 2003.

Mazarr, Michael J. North Korea and the Bomb: A Case Study in Nonproliferation. London: Macmillan Press Ltd., 1995.

McCormack, Timothy L.H. Self-Defense in International Law: The Israeli Raid on the Iraqi Nuclear Reactor. New York: St. Martin's Press, 1996.

McCullough, David. Truman. New York: Simon \& Schuster, 1992.

McDougal, Myres S. “The Soviet-Cuban Quarantine and Self-Defense.” The American Journal of International Law vol. 57, no. 3 (July 1963): 597-604.

McDougal, Myers S. and Florentino P. Feliciano. Law and Minimum World Order. New Haven, CT: Yale University Press, 1961.

McKinney, Cynthia. "Should the U.S. Have a Missile Defense System?” American Legion Magazine vol. 148, no. 1 (January 2000): 42.

McNaugher, Thomas L. "Ballistic Missiles and Chemical Weapons: The Legacy of the Iran-Iraq War." International Security vol. 15, no. 2 (fall 1990): 5-34.

Mearsheimer, John J. The Tragedy of Great Power Politics. New York: W.W. Norton \& 
Company, 2001.

Mearsheimer, John J. and Stephen M. Walt. “An Unnecessary War.” Foreign Policy no. 134 (January/February 2003): 50-59.

Miles, James. "Waiting Out North Korea." Survival vol. 44, no. 2 (summer 2002): 37-49.

Miller, Judith, Stephen Engleberg, and William Broad. Germs: The Ultimate Weapon.

London: Simon \& Schuster UK Ltd., 2001.

Millot, Marc Dean. "Facing the Emerging Reality of Regional Nuclear Adversaries."

The Washington Quarterly vol. 17, no. 3 (summer 1994): 41-71.

Mitchell, Gordon R. Strategic Deception: Rhetoric, Science, and Politics in Missile Defense Advocacy. East Lansing, MI: Michigan State University Press, 2000.

Morgan, Patrick M. Deterrence Now. Cambridge: Cambridge University Press, 2003.

- Deterrence: A Conceptual Analysis. Beverly Hills, CA: Sage Publications, 1977.

Murdoch, Stephen. “Preemptive War: Is It Legal?” The Washington Lawyer vol. 17, no. 5 (January 2003): 24-31.

Nakdimon, Shlomo. First Strike: The Exclusive Story of How Israel Foiled Iraq's Attempt to Get the Bomb. New York: Summit Books, 1987.

Nelson, Robert W. "Low-Yield Earth-Penetrating Nuclear Weapons." Journal of the Federation of American Scientists vol. 54, no. 1 (January/February 2001): 1-5.

Nitze, Paul H. “Deterring Our Deterrent.” Foreign Policy no. 25 (winter 1976-77): 195210.

Noland, Marcus. Avoiding the Apocalypse: The Future of the Two Koreas. Washington D.C.: Institute for International Economics, 2000.

Nye, Joseph S. Jr. The Paradox of American Power: Why the World's Only Superpower Can't Go it Alone. Oxford: Oxford University Press, 2002. 
Oberdorfer, Don. The Two Koreas: A Contemporary History. London: Warner Books, 1997.

Oh, Kongdan and Ralph C. Hassig. North Korea: Through the Looking Glass.

Washington D.C.: Brookings Institution Press, 2000.

O’Hanlon, Michael. “Stopping a North Korean Invasion: Why Defending South Korea is Easier than the Pentagon Thinks." International Security vol. 22, no. 4 (spring 1998): 135-170.

Osgood, Robert. Limited War: The Challenge to American Security. Chicago: University of Chicago Press, 1957.

Panofsky, Wolfgang K. H. "The Mutual-Hostage Relationship Between American and Russia." Foreign Affairs vol. 52, no. 1 (October 1973): 109-118.

Paul, T.V. Asymmetric Conflicts: War Initiation by Weaker Powers. Cambridge:

Cambridge University Press, 1994.

Paul, T.V., Richard J. Harknett, and James J. Wirtz, eds. The Absolute Weapon

Revisited: Nuclear Arms and the Emerging International Order. Ann Arbor, MI: Michigan University Press, 1998.

Payne, Keith B. The Fallacies of Cold War Deterrence and a New Direction. Lexington, KY: The University Press of Kentucky, 2001.

- Deterrence in the Second Nuclear Age. Lexington, KY: The University Press of Kentucky, 1996.

— "Deterring the Use of Weapons of Mass Destruction: Lessons from History." Comparative Strategy vol. 14, no. 4 (October-December 1995): 347-356.

Payne, Keith B. and Lawrence R. Fink. "Deterrence Without Defense: Gambling on Perfection." Strategic Review vol. XVII, no. 1 (winter 1989): 25-40.

Perry, William J. "Preparing for the Next Attack." Foreign Affairs vol. 80, no. 6 
(November/December 2001): 31-45

Pollack, Kenneth M. The Threatening Storm. New York: Random House, 2002.

Powell, Colin L. "A Strategy of Partnerships." Foreign Affairs vol. 83, no. 1 (January/February 2004): 22-34.

Powell, Colin L., with Joseph E. Persico. A Soldier's Way. London: Arrow Books, 1995.

Powell, Robert. "Nuclear Deterrence Theory, Nuclear Proliferation, and National Missile Defense." International Security vol. 27, no. 4 (spring 2003): 86-118.

—. Nuclear Deterrence Theory. Cambridge: Cambridge University Press, 1990.

Quester, George. "The Future of Nuclear Deterrence." Survival vol. 34, no. 1 (spring 1992): 74-88.

Quinlan, Michael. Thinking About Nuclear Weapons. London: Royal United Services Institute for Defence Studies, 1997.

Ranger, Robin and David Wiencek. The Devil's Brews II: Weapons of Mass Destruction and International Security, Bailrigg Memorandum 17. Lancaster: Centre for Defence and International Security Studies, 1997.

Rathjens, G. W. "Flexible Response Options.” Orbis vol. 18, no. 3 (fall 1974): 677-688.

Reiss, Mitchell. Bridled Ambition. Washington D.C.: Woodrow Wilson Center Press, 1995.

Rhodes, Edward. Power and MADness: the Logic of Nuclear Coercion. New York: Columbia University Press, 1989.

Riecke, Henning. “NATO’s Non-Proliferation and Deterrence Policies: Mixed Signals and the Norm of WMD Non-Use." Journal of Strategic Studies vol. 23, no. 1 (March 2000): 25-51.

Ritcheson, Philip L. "Proliferation and the Challenge to Deterrence." Strategic Review vol. XXIII, no. 2 (spring 1995): 38-48. 
Roberts, Brad. "From Nonproliferation to Antiproliferation." International Security vol. 18, no. 1 (summer 1993): 139-173.

Root, Elihu. "The Real Monroe Doctrine." The American Journal of International Law vol. 8, no. 3 (July 1914): 427-442.

Rosen, Stephen Peter. “An Empire, If You Can Keep It.” National Interest vol. 71 (spring 2003): 51-62.

Rumsfeld, Donald H. "Transforming the Military." Foreign Affairs vol. 81, no. 3 (May/June 2002): 20-32.

Russell, Richard L. “CIA's Strategic Intelligence in Iraq.” Political Science Quarterly vol. 117, no. 2 (summer 2002): 191-207.

Sagan, Scott D. “The Commitment Trap: Why the United States Should Not use Nuclear Threats to Deter Biological and Chemical Weapons Attacks." International Security vol. 24 , no. 4 (spring 2000): 85-115.

Sagan, Scott D. and Kenneth N. Waltz. The Spread of Nuclear Weapons: A Debate. New York: W.W. Norton \& Company, 1995.

Sandoval, Robert R. "Consider the Porcupine: Another View of Nuclear Proliferation." The Bulletin of the Atomic Scientists vol. 32, no. 5 (May 1976): 17-19.

Schake, Kori N. and Judith S. Yaphe. The Strategic Implications of a Nuclear-Armed Iran, McNair Paper No. 64. Washington D.C.: Institute for National Strategic Studies, National Defense University, 2001.

Schelling, Thomas C. Arms and Influence. New Haven, CT: Yale University Press, 1966.

—. The Strategy of Conflict. Cambridge, MA: Harvard University Press, 1960.

Schneider, Barry R. Future War and Counterproliferation: U.S. Military Responses to NBC Proliferation Threats. Westport, CT: Praeger, 1999.

—. "Strategies for Coping with Enemy Weapons of Mass Destruction." Airpower 
Journal (special edition 1996): 36-47.

\section{—. Radical Responses to Radical Regimes: Evaluating Preemptive}

Counter-proliferation, McNair Paper No. 41. Washington D.C.: National Defense University Press, May 1995.

Schwarzkopf, H. Norman, with Peter Petre. It Doesn't Take a Hero. London: Bantam Press, 1992.

Sciolino, Elaine. The Outlaw State: Saddam Hussein's Quest for Power and the Gulf Crisis. New York: John Wiley \& Sons, Inc., 1991.

Sepp, Eric M. Deeply Buried Facilities: Implications for Military Operations, Occasional Paper No. 14. Maxwell Air Force Base, AL: Air War College, May 2000.

Shoham, Uri. "The Israeli Raid Upon the Iraqi Nuclear Reactor and the Right to SelfDefense." Military Law Review vol. 109 (summer 1985): 191-223.

Sigal, Leon V. Disarming Strangers: Nuclear Diplomacy with North Korea. Princeton, NJ: Princeton University Press, 1998.

Simes, Dimitri K. “America's Imperial Dilemma." Foreign Affairs vol. 82, no. 6 (November/December 2003): 91-102.

Slocombe, Walter B. "Force, Pre-emption and Legitimacy." Survival vol. 45, no. 1 (spring 2003): 117-130.

Snyder, Jed C. “The Road to Osiraq: Baghdad's Quest for the Bomb." Middle East Journal vol. XXXVII (autumn 1983): 565-593.

Sokolski, Henry D., ed. Prevailing in a Well-Armed World: Devising Competitive Strategies Against Weapons Proliferation. Carlisle, PA: Strategic Studies Institute, March 2000.

Spector, Leonard S., with Jacqueline R. Smith. Nuclear Ambitions: The Spread of 
Nuclear Weapons 1989-1990. Boulder, CO: Westview Press, 1990.

Speer, Albert. Inside the Third Reich. New York: Macmillan Company, 1970.

Spiers, Edward M. Weapons of Mass Destruction: Prospects for Proliferation. London: Macmillan Press Ltd., 2000.

Stein, Janice Gross. "Deterrence and Compellence in the Gulf, 1990-91: A Failed or Impossible Task?" International Security vol. 17, no. 2 (fall 1992): 147-179.

Stern, Jessica. The Ultimate Terrorists. Cambridge, MA: Harvard University Press, 1999.

Sterner, Michael. "Closing the Gate: The Persian Gulf War Revisited." Current History vol. 96, no. 606 (January 1997): 13-19.

Stone, Julius. Aggression and World Order. London: Stevens \& Sons Limited, 1958.

Strachan, Hew. The First World War, Volume One. Oxford: Oxford University Press, 2001.

Suh, Dae-sook. Kim Il Sung. New York: Columbia University Press, 1988.

Takeyh, Ray. "Re-imagining U.S.-Iranian Relations.” Survival vol. 44, no. 3 (autumn 2002): 23-36.

Tanter, Raymond. Rogue Regimes: Terrorism and Proliferation. London: Macmillan Press Ltd., 1999.

Taylor, A.J.P. The Struggle for Mastery in Europe, 1848-1918. Oxford: Oxford University Press, 1954.

Thucydides. The Peloponnesian War, translated by Rex Warner. London: Cassell \& Company Ltd., 1954.

Timmerman, Kenneth R. The Death Lobby: How the West Armed Iraq. London: Fourth Estate Limited, 1992.

Utgoff, Victor A. "Proliferation, Missile Defence and American Ambitions." Survival 
vol. 44 , no. 2 (summer 2002): 85-102.

-, ed. The Coming Crisis: Nuclear Proliferation, U.S. Interests, and World Order. Cambridge, MA: MIT Press, 2000.

Van Creveld, Martin. Nuclear Proliferation and the Future of Conflict. New York: The Free Press, 1993.

Walt, Stephen M. “Beyond Bin Laden: Reshaping U.S. Foreign Policy.” International Security vol. 26, no. 3 (winter 2001-02): 56-78.

Waltz, Kenneth N. “A Reply.” Security Studies vol. 4, no. 4 (summer 1995): 802-805.

—. The Spread of Nuclear Weapons: More May Be Better, Adelphi Paper No. 171.

London: International Institute for Strategic Studies, 1981.

Walzer, Michael. Just and Unjust Wars. New York: BasicBooks, 1977.

Watman, Kenneth and Dean Wilkening, with John Arquilla and Brian Nichiporuk. U.S. Regional Deterrence Strategies. Santa Monica, CA: RAND, 1995.

Weissman, Steve and Herbert Krosney. The Islamic Bomb: the Nuclear Threat to Israel and the Middle East. New York: Times Books, 1981.

Wich, Richard. Sino-Soviet Crisis Politics: A Study of Political Change and Communication. Cambridge, MA: Harvard University Press, 1980.

Wilkening, Dean. Ballistic-Missile Defence and Strategic Stability, Adelphi Paper No.

334. Oxford: Oxford University Press, International Institute for Strategic Studies, 2000.

Wilkening, Dean and Kenneth Watman. Nuclear Deterrence in a Regional Context. Santa Monica, CA: RAND, 1995.

Wirtz, James J. "Counterproliferation, Conventional Counterforce and Nuclear War." Journal of Strategic Studies vol. 23, no. 1 (March 2000): 5-24.

Wirtz, James J. and Jeffrey A. Larsen. Rockets Red Glare: Missile Defense and the 
Future of World Politics. Boulder, CO: Westview, 2001.

Wirtz, James J. and James A. Russell. "U.S. Policy on Preventive War and Preemption." The Nonproliferation Review vol. 10, no. 1 (spring 2003): 113-123.

Wit, Joel S. "North Korea: The Leader of the Pack." The Washington Quarterly vol. 24, no. 1 (winter 2001): 77-92.

Wohlstetter, Albert. "The Delicate Balance of Terror." Foreign Affairs vol. 37, no. 2 (January 1959): 211-234.

Wolf, Barry. When the Weak Attack the Strong: Failures of Deterrence, RAND Note. Santa Monica, CA: RAND, 1991.

Wolfgang, Marvin E. International Terrorism. Beverly Hills, CA: Sage Publications, 1982.

Wright, Quincy. "The Cuban Quarantine.” The American Journal of International Law vol. 57 , no. 3 (July 1963): 546-565.

Zagare, Frank C. and D. Marc Kilgour. Perfect Deterrence. Cambridge: Cambridge University Press, 2000.

\section{Newspaper Articles}

Anderson, Scott. "The Makeover." New York Times Magazine, 19 January 2003.

Apple, R.W. Jr. "Allies Destroy Iraqis' Main Force; Kuwait is Retaken After 7 Months." New York Times, 28 February 1991.

Associated Press. "Bin Laden Said to Have Sought Nuclear Arms." Baltimore Sun, 30 December 2002.

Baker, Peter. "But What if the Iraqis Strike First?" Washington Post, 23 January 2003.

Barbash, Fred. "U.N. Nuclear Agency Censures Iran." Washington Post, 26 November 2003. 
Bender, Bryan. "Regime Ordered Chemical Attack, Investigator Says." Boston Globe, 8 August 2003.

—. "USA Planning Warhead to Hit CB Weapons." Jane's Defence Weekly, 24 March 1999.

Bernstein, Richard. "U.N. Atom Agency Seeks Wider Scrutiny of Iran, But is Rebuffed." New York Times, 20 June 2003.

Beyer, Lisa. "Coping with Chemicals.” Time, 25 February 1991.

Boettcher, Mike. "Evidence Suggests Al Qaeda Pursuit of Biological, Chemical Weapons." $C N N, 14$ November 2001

Bolton, John R. "A Dictatorship at the Crossroads." Asian Wall Street Journal, 1 August 2003.

Brinkley, Joel and William J. Broad. "U.S. Lags in Recovering Fuel Suitable for Nuclear Arms." New York Times, 7 March 2004.

Brooke, James. "North Korea Moves to Win Some Friends Before Nuclear Talks." New York Times, 5 August 2003.

_ . "Infiltrators of North Korea: Tiny Radios." New York Times, 3 March 2003.

_ . "North Korea Says it Plans to Expel Nuclear Monitors." New York Times, 28 December 2002.

_. "A Missile Shield Appeals to a Worried Japan." New York Times, 11 November 2002.

Bryen, Stephen D. "Ironic Chemistry: The U.N. Boosts Saddam's Threat." Wall Street Journal, 9 December 2002

Broad, William J. "Sleuths Patrol Nations for Nuclear Mischief." New York Times, 30 December 2003.

__. "Facing a Second Nuclear Age," New York Times, 3 August 2003. 
— "Call for New Breed of Nuclear Arms Faces Hurdles." New York Times, 11 March 2002.

—_. "U.S. Tightening Rules on Keeping Scientific Secrets." New York Times, 17 February 2002.

—. "Achilles' Heel in Missile Plan: Crude Weapons." New York Times, 27 August 2001 .

—. "The Nuclear Shield: Repelling an Attack." New York Times, 30 June 2000.

Broad, William J., Stephen Engelberg, and James Glanz. “Assessing Risks, Chemical, Biological, Even Nuclear." New York Times, 1 November 2001.

Broad, William J., David E. Sanger, and Raymond Bonner. "A Tale of Nuclear Proliferation." New York Times, 12 February 2004.

Brokaw, Tom. "How the Home Front Can Help." New York Times, 19 February 2004. Brooke, James. "North Korea Moves to Win Some Friends Before Nuclear Talks." New York Times, 5 August 2003.

Burns, John F., with Eric Schmitt. "U.S. Forces Join Big Assault on Afghan Stronghold." New York Times, 3 March 2002.

Calabresi, Massimo. “Iran's Nuclear Threat.” Time, 17 March 2003.

Carter, Ashton B. and William J. Perry. "Back to the Brink." Washington Post, 20 October 2002.

Cha, Ariana Eunjung. "New U.S. Weapon: Jobs for Iraqi Men.” Washington Post, 22 February 2004.

Chandrasekaran, Rajiv. "For India, Deterrence May Not Prevent War." Washington Post, 17 January 2002.

Choe, Sang-hun. "North Korea Rejects U.S. Nuclear Proposal." Philadelphia Inquirer, 15 December 2003. 
Church, George J. “Targeting Gaddafi." Time, 21 April 1986.

Cody, Edward. "U.S.: China is Ally Against Proliferation." Washington Post, 17 February 2004.

Coman, Julian. "Pentagon Wants 'Mini-Nukes' to Fight Terrorists." London Sunday Telegraph, 26 October 2003.

Connolly, Ceci. "Readiness for Chemical Attack Criticized." Washington Post, 4 June 2003.

Cooper, Richard T. “Making Nuclear Bombs “Usable.”' Los Angeles Times, 3 February 2003.

Coryell, George. "New Humvee Protects Against All Chemical, Biological Warfare." Tampa Tribute, 11 March 2003.

Cox, Matthew and William Matthews. "The Best Protective Gear in the World?" Air Force Times, 24 February 2003.

Curl, Joseph. “North Korea Gets Stern Warning.” Washington Times, 15 May 2003.

Dao, James. "Senior Bush Defends '91 Decision on Iraq." New York Times, 1 March 2003.

—. "Bush Urges Chinese President to Push North Korea on Arms." New York Times, 9 February 2003.

—. "Pentagon's Worry: Iraqi Chemical Arms." New York Times, 19 May 2002.

__. "Pentagon Optimistic About Missile Shield." New York Times, 15 April 2002.

Delpech, Therese. “The Weapons Hunt.” Wall Street Journal, 16 April 2003.

Demick, Barbara. “N. Korea Denies It Has a Warhead." Los Angeles Times, 13 January 2004.

— "N. Korea Says it Will Be a No-Show at Six-Party Talks." Los Angeles Times, 10 December 2003. 
Demick, Barbara and Mark Magnier. "The 2 Koreas Get a Land Link." Los Angeles Times, 15 February 2003.

Devroy, Ann and Patrick E. Tyler. "Bush Launches Strike to Seize Noriega; Fighting Widespread in Panama City." Washington Post, 20 December 1989.

Diamond, John. “N. Korea Keeps U.S. Intelligence Guessing." USA Today, 10 March 2003.

—. "Split over Iraq Grows More Public." USA Today, 19 August 2002.

Diedrich, John. "SpaceCom Improves Ability to Dodge Scuds." Colorado Springs Gazette, 31 January 2003.

Dobbs, Michael. “A Story of Iran's Quest for Power.” Washington Post, 13 January 2002.

Dowd, Maureen. "The Jihad All-Stars." New York Times, 27 August 2003.

Doyle, Neil. “Al Qaeda Nukes Are Reality, Intelligence Says.” Washington Times, 28 October 2002.

Drogin, Bob. “’91 Iraq Toxics Plan Reported.” Los Angeles Times, 10 March 2003. Drummond, James and Edward Alden. "Rumsfeld Orders Extra Forces to Mideast." Financial Times, 13 January 2003.

Duffy, Michael. “Weapons of Mass Disappearance.” Time, 9 June 2003.

—_. "Does Might Make Right?" Time, 30 September 2002.

Easterbrook, Gregg. “American Power Moves Beyond the Mere Super.” New York Times, 27 April 2003.

Eckert, Paul. “N. Korea Still Recognizes '94 Pact With U.S., Ex-Envoy Says.”

Washington Post, 7 November 2002.

Eckholm, Erik. "Experts Try to Make Missile Shield Plan Palatable to China." New York Times, 28 January 2001. 
Efron, Sonni. "U.S. Officials in a Quandary Over N. Korea." Los Angeles Times, 8 May 2003.

—_. "U.S. Said to be Resigned to a Nuclear Korea." Los Angeles Times, 5 March 2003.

ElBaradei, Mohamed. "Saving Ourselves From Self-Destruction.” New York Times, 12 February 2004.

Evans, Michael. “Britain 'Needs Missile Shield.’” London Times, 13 November 2002.

_. "SAS Plan to Blow Up Saddam's Germ Sites.” London Times, 12 July 2002.

Faiola, Anthony. "N. Korea Claims Nuclear Advance." Washington Post, 3 October 2003.

Fathi, Nazila. "Iranian Lawmaker Opens Door to American Talks.” New York Times, 16 December 2002.

Finer, Jonathan. "A High-Tech Pilot Who Keeps His Feet on the Ground.” Washington Post, 7 March 2003.

Flournoy, Michele and Vinca LaFleur. “Quick-Stick Doctrine.” Washington Post, 18 June 2002.

Frankel, Glenn. “A 'Long Slog' Led to Libya's Decision.” Washington Post, 21 December 2003.

Frantz, Douglas. "Libya's Arms Development Surprises U.N." Los Angeles Times, 21 February 2004.

—. "N. Korea's Nuclear Success is Doubted." Los Angeles Times, 9 December 2003.

—. "Iran Closes in On Ability to Build a Nuclear Bomb." Los Angeles Times, 4 August 2003.

French, Howard W. "Official Says U.S. Will Reposition its Troops in South Korea." 
New York Times, 3 June 2003.

_ _ "South Korea Chief Says North Received Cash in Bid for Peace." New York Times, 14 February 2003.

_ . "North Korea Restarts Reactor With Ability to Fuel Arms." New York Times, 6 February 2003.

_ .U.S. Gets Warning From North Korea." New York Times, 25 December 2002.

_. "North Korea Warns the U.S. to Negotiate or Risk 'Catastrophe," New York Times, 24 December 2002.

_ . "North Korea Clarifies Statement on A-Bomb," New York Times, 19 November 2002.

_ . "North Korean Radio Asserts Country Has Nuclear Arms." New York Times, 18 November 2002.

Friedman, Thomas L. "Iraq, Upside Down.” New York Times, 18 September 2002.

—_. "Who's Crazy Here?” New York Times, 15 May 2001.

_. "Envoy to Iraq, Faulted in Crisis, Says She Warned Hussein Sternly." New York Times, 21 March 1991

Fulghum, David A. "Iraq's Hidden Weapon “Are Likely Underground." Aviation Week \& Space Technology, 16 December 2002.

__. "Microwave Weapons May Be Ready for Iraq." Aviation Week \& Space Technology, 5 August 2002.

Fuller, Thomas. "Iraq Vows 'Unconventional' Tactics to Defend Capital." New York Times, 4 April 2003.

Gellman, Barton. "Iraq's Arsenal Was Only on Paper." Washington Post, 7 January 2004.

—_. "Frustrated, U.S. Arms Team to Leave Iraq." Washington Post, 11 May 2003. 
—_. "Fears Prompt U.S. to Beef Up Nuclear Terror Detection." Washington Post, 3 March 2002.

Gellman, Barton and Walter Pincus. "Depiction of Threat Outgrew Supporting Evidence." Washington Post, 10 August 2003.

Gertz, Bill. "U.S. Commander Fears N. Korea Would Sell Nukes." Washington Times, 18 November 2003.

—. “ $2{ }^{\text {nd }}$ N. Korean Nuclear Site Not Likely.” Washington Times, 22 July 2003.

__. "CIA Says Al-Qaeda Ready to Use Nukes." Washington Times, 3 June 2003.

_. "Coalition Still Wary of Chemical Weapons." Washington Times, 5 April 2003.

__. "N. Korea Ship Gets Arms In and Out." Washington Times, 18 February 2003.

_. "China Ships North Korea Ingredient for Nuclear Arms." Washington Times, 17 December 2002.

__. "North Korea Can Build Nukes Right Now." Washington Times, 22 November 2002.

Gibbs, Nancy and Michael Ware. "Chasing a Mirage.” Time, 6 October 2003.

Gilbert, Craig. "Can U.S. Be First to Attack Enemy?" Milwaukee Journal Sentinel, 31 March 2002.

Glennon, Michael J. "Preempting Terrorism: The Case for Anticipatory Self-Defense." The Weekly Standard vol. 7, no. 19 (28 January 2002).

Gonzalez, David. "At Cuba Conference, Old Foes Exchange Notes on 1962 Missile Crisis." New York Times, 14 October 2002.

Goodman, Peter S. "N. Korea Moves to Activate Complex." Washington Post, 27 December 2002.

—. "N. Korean Official Threatens 'Fight to the End' With U.S." Washington Post, 25 December 2002. 
Gordon, Michael R. "Iraq Said to Plan Strategy of Delay and Urban Battle." New York Times, 16 February 2003.

- "Iraq Said to Plan Tangling the U.S. in Street Fighting." New York Times, 26 August 2002.

—. "U.S. Troops Move in Panama in Effort to Seize Noriega; Gunfire is Heard in Capital." New York Times, 20 December 1989.

Gordon, Michael R. and Felicity Barringer. "North Korea Wants Arms and More Aid From U.S." New York Times, 13 February 2003.

Gosden, Christine. "Why I Went, What I Saw." Washington Post, 11 March 1998.

Gottemoeller, Rose. “On Nukes, We Need to Talk.” Washington Post, 2 April 2002.

Graham, Bradley. "Gaps in Plan to Halt Arms Trade." Washington Post, 3 August 2003.

—_. "Scientists Raise Doubts About Missile Defense." Washington Post, 16 July 2003.

—. "Improved Air Defense Gets Tryout in Combat." Washington Post, 21 March 2003.

—. "As U.S. Girds for Worst in Iraq, Retaliation Isn't Clear-Cut Issue." Washington Post, 29 January 2003.

—. "'Scorched Earth' Plans in Iraq Cited.” Washington Post, 19 December 2002.

Grant, Thomas D. "For an Iraq Amnesty." Washington Post, 20 August 2002.

Greenhouse, Steven. "Perry Says U.S. Considered Bombing North Korean Reactor." The Houston Chronicle, 25 January 1995.

Grier, Peter and Faye Bowers. "Pyongyang Options Opening Up." Christian Science Monitor, 9 January 2003.

Guynn, Jessica. “As Coalition Nears Baghdad, Chemical Arms a Question Mark.” The Mercury News, 3 April 2003. 
Hendren, John. "Pentagon Battles Unknown Preparing for a Toxic War." Los Angeles Times, 29 September 2002.

_ .U.S. Studies Foam Bombs Among Options to Isolate Chemicals." Los Angeles Times, 18 July 2002.

Hersh, Seymour. "Target Gadaffi: Reagan's Secret Plot.” The London Times, 22 February 1987.

Hoge, Warren. "Cyprus Greeks and Turks Agree on Plan to End 40-Year Conflict." New York Times, 14 February 2004.

Hsu, Spencer S. “Sensors May Track Terror's Fallout.” Washington Post, 2 June 2003.

Hulse, Carl. "Senate Votes to Lift Ban on Producing Nuclear Arms." New York Times, 21 May 2003.

Ibrahim, Youssef M. "Iran Reports New Iraqi Gas Raids, And Says Cities May be Hit Next." New York Times, 2 April 1988.

Jaffe, Greg. "Intelligence Suggests Hussein Allowed Chemical-Weapon Use." Wall Street Journal, 20 March 2003.

_. "Iraq's Scuds Still Keep the Pentagon Guessing." Wall Street Journal, 15 October 2002.

Jehl, Douglas. "Iraq Removed Arms Material, Aide Says." New York Times, 29 October 2003.

Jehl, Douglas and David E. Sanger. "Powell's Case A Year Later: Gaps in Picture of Iraq Arms." New York Times, 1 February 2004.

Kahn, Joseph. "Diplomats See Modest Progress in North Korea Nuclear Talks." New York Times, 28 February 2004.

— . "North Korea Says it is Against More Talks." New York Times, 30 August 2003. Kelley, Matt. "Iraq Can Make Chemical Weapons That Penetrate U.S. Protective Gear." 
Associated Press, 17 November 2002.

Kemper, Vicki. "Vaccine Program Going Well, Military Reports." Los Angeles Times, 14 February 2003.

Kessler, Glenn. "Bush Signals Patience on North Korea is Waning." Washington Post, 4 March 2004.

_ . "U.S. Agrees to Statement on North Korea Talks." Washington Post, 8 December 2003.

. "N. Korea Seeks to Exclude U.S. Official From Talks." Washington Post, 4 August 2003.

Kessler, Glenn and Walter Pincus. "N. Korea Stymied on Plutonium Work." Washington Post, 20 March 2003.

Kessler, Glenn and Peter Slevin. "Preemptive Strikes Must Be Decisive, Powell Says." Washington Post, 15 June 2002.

Kessler, Glenn and Robin Wright. "U.S., Allies Agree on Iran Move." Washington Post, 25 November 2003.

Kimery, Anthony L. "Searching for 'Dirty Bombs.”' Insight Magazine, 21 January 2003.

Kirk, Don. "North Korea Regrets Naval Clash With Seoul and Seeks Talks." New York Times, 26 July 2002.

Kiśsling, Elise. "Preemption an Option for EU." Frankfurter Allgemeine Zeitung, 30 May 2003.

Knickerbocker, Brad. "Risk of Terrorism to Nation's Food Supply." Christian Science Monitor, 24 December 2002.

Knowlton, Brian. "War Largely Going as Planned, Pentagon Says.” New York Times, 9 April 2003.

Koch, Andrew. "Dual Delivery is Key to Buried Targets." Jane's Defence Weekly vol. 
33, issue 10 (8 March 2000).

Konviser, Bruce I. "NATO Plans Special Brigade to Fight Terror Risks.” Washington Times, 5 February 2004.

Kralev, Nicholas. "North Korea Offers Nigeria Missile Deal." Washington Times, 29 January 2004.

—. "U.S. Asks Aid Barring Arms From Rogue States." Washington Times, 5 June 2003.

—. "NATO to Expand with New Focus on Terror Defense." Washington Times, 20 November 2002.

Krauthammer, Charles. “Calling Iraq's Bluff.” Washington Post, 30 January 2004.

—. "Get Ready for War." Washington Post, 3 June 1994.

Kristof, Nicholas D. “Secret Scary Plans.” New York Times, 28 February 2003.

Lacey, Marc. "Powell Fails to Persuade NATO on Antimissile Plan." New York Times, 30 May 2001.

Lake, Anthony and Robert Gallucci. "Negotiating with Nuclear North Korea." Washington Post, 6 November 2002.

Larking, John. "North Korea Relaxes Economy, Reaches Out to U.S. and Japan." Wall Street Journal, 2 August 2002.

Lee, Soo-Jeong. "Bush Rejects N. Korea's Offer of Nuclear Programs Freeze for Energy." Washington Post, 10 December 2003.

Limbacher, Carl. “Clinton: I Threatened to Attack North Korea.” NewsMax.com, 24 November 2002.

Locy, Toni and Kevin Johnson. "Suspect Helping U.S. Gauge Al-Qaeda's Arsenal." USA Today, 15 January 2003.

Loeb, Vernon. "Biodefense Agency Urged for Safety of U.S. Troops." Washington Post, 
23 January 2004.

—. "U.S. Gains in Attacking Mobile Arms." Washington Post, 5 July 2002.

Lyall, Sarah. “Arrest of Terror Suspects in London Turns up a Deadly Toxin.” New York Times, 8 January 2003.

Lynch, Colum. "Bin Laden Sought Uranium, Jury Told.” Washington Post, 8 February 2001.

MacFarquhar, Neil. “Washington's Arabic TV Effort Gets Mixed Reviews.” New York Times, 20 February 2004.

—. "A Khomeini Breaks With His Lineage to Back U.S." New York Times, 6 August 2003.

—. "Student Protests in Tehran Become Nightly Fights for Freedom." New York Times, 14 June 2003.

Marquand, Robert. "China Brings Shift on Nukes to Korea Talks.” Christian Science Monitor, 24 February 2004.

Marquis, Christopher. "New System Begins Rerouting U.S. Aid for Poor Countries." New York Times, 22 February 2004.

Masland, Tom with Douglas Waller. “Are We Ready for Chemical War?” Newsweek, 4 March 1991.

McAllister, J.F.O. “Pyongyang’s Dangerous Game.” Time, 4 April 1994.

McGeary, Johanna. “What Does Saddam Have?” Time, 16 September 2002.

Meyer, Josh. "Al Qaeda Feared to Have 'Dirty Bombs."” Los Angeles Times, 8 February 2003.

Miller, Bill. "Denver Stages Mock Terror Attack.” Washington Post, 23 February 2002.

Miller, Greg. “Analysis of Iraqi Weapons 'Wrong."' Los Angeles Times, 31 May 2003. “U.S. Claims 90\% Hit Rate in Missile Plan." Los Angeles Times, 19 March 
2003.

Miller, Judith. "U.S. is Deploying a Monitor System for Germ Attacks.” New York Times, 22 January 2003.

—. "Qaeda Videos Seem to Show Chemical Tests." New York Times, 19 August 2002.

—. "Bush to Request Big Spending Push on Bioterrorism." New York Times, 4 February 2002.

Moaveni, Azadeh. “Are Iran's Nuclear Promises Real?” Los Angeles Times, 21 November 2003.

Myers, Steven Lee. "The Targets: Jets Said to Avoid Poison Gas Sites." New York Times, 18 December 1998.

Myers, Steven Lee and Tim Weiner. "After the Attack: The Chemicals.” New York Times, 27 August 1998.

New York Times. "In Defense of Deterrence." 10 September 2002.

Nye, Joseph S. "Hourglass Runs Low.” Los Angeles Times, 12 March 2003.

O’Hanlon, Michael. “Think Bigger on North Korea.” Washington Post, 17 September 2003.

Ottaway, David B. “In Mideast, Warfare With a New Nature." Washington Post, 5 April 1988.

Pan, Philip P. “Nuclear Talks Clouded by N. Korea's Denial of Enrichment Effort." Washington Post, 25 February 2004.

Perry, William J. “It's Either Nukes or Negotiation.” Washington Post, 23 July 2003.

Perry, William J. and Ashton B. Carter, "The Crisis Last Time.” New York Times, 19 January 2003.

Peterson, Scott. "Iran's Nuclear Challenge: Deter, not Antagonize." The Christian 
Science Monitor, 21 February 2002

Pincus, Walter. "Future of U.S. Nuclear Arsenal Debated." Washington Post, 4 May 2003.

—. "U.S. Has Still Not Found Iraqi Arms." Washington Post, 26 April 2003.

—. "U.S. Explores Developing Low-Yield Nuclear Weapons." Washington Post, 20 February 2003

—. "U.S. Effort Aimed at Iraqi Officers." Washington Post, 30 September 2002.

——. "U.S. Nuclear Arms Stance Modified by Policy Study." Washington Post, 23 March 2002.

—_. "U.S. Alters Estimate of Threats." Washington Post, 11 January 2002.

—. "Nuclear Strike on Bunkers Assessed." Washington Post, 20 December 2001.

—_. "Military Study Mulled Deterrence of 'Fear." Washington Post, 5 July 2001.

Pincus, Walter and Dana Priest, "Hussein's Weapons May Have Been Bluff."

Washington Post, 1 October 2003.

Pollack, Kenneth. “Why Iraq Can't Be Deterred.” New York Times, 26 September 2002.

Pomfret, John. "Reforms Turn Disastrous for North Koreans.” Washington Post, 27 January 2003.

Preston, Julia. "North Korea Demands U.S. Agree to Nonaggression Pact." New York Times, 25 October 2002.

Price, Joyce Howard. "U.S. Reprisal to be 'Annihilation." Washington Times, 9 September 2002.

Raspberry, William. “Our Insane Focus on Iraq.” Washington Post, 9 September 2002. Ratnesar, Romesh. "Can They Strike Back?” Time, 3 February 2003.

Reid, T. R. "North Korea Warns of 'Brink of War."' Washington Post, 23 March 1994. Revkin, Andre C. “Advanced Armaments.” New York Times, 3 December 2001. 
Richter, Paul. “Missile Defense System Doubts.” Los Angeles Times, 22 January 2004.

—. "U.S. Works up Plan for Using Nuclear Arms." Los Angeles Times, 9 March 2002.

Ricks, Thomas E. and Peter Slevin. "Spain, U.S. Seize N. Korean Missiles." Washington Post, 11 December 2002.

Riordan, Teresa. "Plastic Pods for Biological Attacks.” New York Times, 30 September 2002.

Rohde, David and David E. Sanger. "Key Pakistani Said to Admit Atom Transfers." New York Times, 2 February 2004.

Roosevelt, Ann. “New Systems Could Improve 'Next Great Scud Hunt."” Defense Week, 25 November 2002.

Rumsfeld, Donald H. "Defense for the $21^{\text {st }}$ Century." Washington Post, 22 May 2003.

Sakamaki, Sachiko and Doug Struck. "Japan Cracks Down on Firms Tied to N. Korea." Washington Post, 22 May 2003.

Sanchez, Rene. "Robot Race is Giant Step for Unmanned Kind.” Washington Post, 10 March 2004.

Sands, David R. "Israeli General Says Saudis Seek to Buy Pakistan Nukes." Washington Times, 23 October 2003.

Sanger, David E. "North Korea Says it Has Made Fuel for Atom Bombs." New York Times, 15 July 2003.

_. "Bush Shifts Focus to Nuclear Sales by North Korea." New York Times, 5 May 2003.

—. "North Korea Says it Now Possesses Nuclear Arsenal." New York Times, 25 April 2003.

—_ "U.S. Officials Fear Iraqis Plan to Use Gas on G.I.'s." New York Times, 25 
March 2003.

—. "U.S. Sees Quick Start of North Korean Nuclear Site.” New York Times, 1 March 2003.

. "North Korea Open Unofficial Channel for U.S. Talks." New York Times, 10 January 2003.

—. "In North Korea and Pakistan, Deep Roots of Nuclear Barter." New York Times, 24 November 2002.

Sanger, David E. and William J. Broad. "From Rogue Nuclear Programs, Web of Trails Leads to Pakistan." New York Times, 3 January 2004.

Sanger, David E. and James Dao. "North Korea Says It Regains Access to Its Plutonium." New York Times, 23 December 2002.

Sanger, David E. and Howard W. French. "North Korea Prompts U.S. to Investigate Nuclear Boast." New York Times, 1 May 2003

Sanger, David E. and Eric Schmitt. "Satellites Said to See Activity at North Korean Nuclear Site." New York Times, 31 January 2003.

Sanger, David E. and Thom Shanker. "North Korea Hides New Nuclear Site, Evidence Suggests." New York Times, 20 July 2003.

_. "U.S. Sending 2 Dozen Bombers in Easy Range of North Koreans." New York Times, 5 March 2003.

—. "U.S. Plans Offer to Russia to End ABM Treaty Dispute." New York Times, 28 May 2001.

Savage, David G. "Nuclear Plan Meant to Deter." Los Angeles Times, 11 March 2002. Scarborough, Rowan. "Saddam Ready to Kill Iraqis, Blame U.S." Washington Times, 12 March 2003.

Schactman, Noah. "A War of Robots, All Chattering on the Western Front." New York 
Times, 11 July 2002.

Schmitt, Eric. “U.S. General Maps New Tactic to Pursue Taliban and Qaeda.” New York Times, 18 February 2004.

— .U.S. Would Use Drones to Attack Iraqi Targets." New York Times, 6 November 2002.

Schmitt, Eric and David E. Sanger. "Admiral Seeks Deterrent Force in Korea Crisis." New York Times, 1 February 2003.

Scowcroft, Brent. “Don't Attack Saddam.” Wall Street Journal, 15 August 2002.

Shanker, Thom. "Lessons from Iraq Include How to Scare North Korean Leader." New York Times, 12 May 2003.

Shanker, Thom and David Johnston. "U.S. Lists Iraqis to Punish, or to Work With." New York Times, 26 February 2003.

Shenon, Philip. "U.S. Widens Checks at Foreign Ports." New York Times, 12 June 2003.

—. "Border Inspectors to Look for Radioactive Material." New York Times, 1 March 2003.

—_. "North Korea Says Nuclear Program Can Be Negotiated." New York Times, 3 November 2002.

Sheridan, Michael. "Koreans May Have Five Nuclear Missiles." London Sunday Times, 27 October 2002.

Sherwell, Philip and David Wastell. "Iraq Has Poison Bombs.” London Sunday Telegraph, 23 February 2003.

Sirak, Michael. 'US Air Force Set to Acquire Chem-Bio 'Agent Defeat' Weapons Soon." Jane's Defence Weekly, 4 December 2002.

Slevin, Peter. "U.S. Met with Iranians on War.” Washington Post, 9 February 2003. Slevin, Peter and Glenn Kessler. "U.S. to Seek Mideast Reforms." Washington Post, 21 
August 2002.

Slevin, Peter and Joby Warrick. "U.N. Finds Uranium Enrichment Tools in Iraq." Washington Post, 20 February 2004.

Smith, Craig S. "Alarm Raised Over Quality of Uranium Found in Iran." New York Times, 11 March 2004.

Smith, Michael. "Saddam to be Target of Britain's ‘E-Bomb." London Daily Telegraph, 26 August 2002.

Smith, R. Jeffrey. "Perry Sharply Warns North Korea." Washington Post, 31 March 1994.

—_. "U.S. Warns of Retaliation if Iraq Uses Poison Gas." Washington Post, 9 August 1990.

Smith, Stephen. "U.S. Farms Called Vulnerable to Terrorism." Boston Globe, 22 November 2002.

Smucker, Philip. "Iraq Flexes its Military Trump Card." Christian Science Monitor, 19 March 2003.

Stober, Dan. “Nuclear 'Bunker Busters’ Sought.” San Jose Mercury News, 23 April 2003.

Stone, Andrea. "Americans in Survey Support First Strike." USA Today, 26 June 2002.

Stout, David. "Bush Says Libya Will Allow Arms Inspections." New York Times, 19 December 2003.

—_ "Bush Again Accuses Iran and Syria of Harboring Terrorists." New York Times, 21 July 2003.

—_ "Rumsfeld Says, if Necessary, U.S. Can Fight 2 Wars at Once." New York Times, 23 December 2002.

_ . "Bush and Seoul Call North Korea Nuclear Plan 'Unacceptable."” New York 
Times, 13 December 2002.

Struck, Doug. “Threat Erodes Japan's Pacifism.” Washington Post, 15 February 2003.

—. "U.S. Signals It Won't Seek Sanctions Against N. Korea." Washington Post, 23 January 2003.

—. "Crisis Could Push N. Korea to Expel Nuclear Inspectors." Washington Post, 14 November 2002.

—. "For North Korea, U.S. is Violator of Accords." Washington Post, 21 October 2002.

Struck, Doug and Glenn Kessler. "Foes Giving in to N. Korea's Nuclear Aims."

Washington Post, 5 March 2003.

Swain, John and James Adams. "Saddam Gives Local Commanders Go-Ahead for Chemical Attacks." Sunday Times, 3 February 1991.

Thompson, Mark. "The Great Scud Hunt." Time, 23 December 2002.

—. "Well, Maybe a Nuke or Two." Time, 11 April 1994.

Tiboni, Frank. “War Game Stuns U.S. Strategists.” Defense News, 12 May 2003.

Timmerman, Kenneth R. “Gadhafi's Mea Culpa on Arms, Terror.” Washington Times, 4 March 2004.

Torchia, Christopher. "Suspected N. Korean Chemicals Worry U.S.” Washington Post, 23 August 2003.

—. “N. Korea Warns U.S. Risking Nuclear War.” Washington Post, 24 December 2002.

Toth, Robert. “American Support Grows for Use of Nuclear Arms.” Los Angeles Times, 3 February 1991.

Tyler, Patrick E. “Officers Say U.S. Aided Iraq in War Despite Use of Gas.” New York Times, 18 August 2002. 
_. "Putin Invites West to Work on a Defense for Missiles." New York Times, 21 February 2001.

—_ "As China Threatens Taiwan, It Makes Sure U.S. Listens." New York Times, 24 January 1996.

__. "Stirring the Iraqi Pot." New York Times, 21 March 1991.

—_ "Both Iraq and Iran Gassed Kurds in War, U.S. Analysis Finds." Washington Post, 3 May 1990.

Tyler, Patrick E. David E. Sanger. "Pakistan Called Libya's Source of Atom Design." New York Times, 6 January 2003.

Tyson, Ann Scott. "For Army, A New Primer in Chemical War." Christian Science Monitor, 21 October 2002.

_. "Nuclear Plan Changes Calculus of Deterrence." The Christian Science Monitor, 14 March 2002.

Van Natta, Don Jr. "Al Qaeda Hobbled by Latest Arrest, U.S. Says.” New York Times, 3 March 2003.

Vick, Karl. “Another Nuclear Program Found in Iran.” Washington Post, 24 February 2004.

—. "U.S. Talks Possible, Iranian Aide Says." Washington Post, 8 January 2004.

—. "U.S., Sudan Trade Claims on Factory." Washington Post, 25 August 1998.

Viorst, Milton. "Imagining the Worst-Case Scenario in Iraq." New York Times, 12 September 2002.

Warrick, Joby. "Iranian Nuclear Plans Found." Washington Post, 13 February 2004.

_ . "Nuclear Program in Iran Tied to Pakistan." Washington Post, 21 December 2003.

__. "Iran Admits Foreign Help On Nuclear Facility." Washington Post, 27 August 
2003.

—_. "Enriched Uranium Traces Found in Iran." Washington Post, 19 July 2003.

—_. "Bush to Seek Funds for Fighting 'Dirty Bombs." Washington Post, 30 January 2003.

—. "Uncertain Ability to Deliver a Blow." Washington Post, 5 September 2002.

Warrick, Joby and Glenn Kessler. "Iran's Nuclear Program Speeds Ahead." Washington Post, 10 March 2003.

Warrick Joby and John Mintz. "Lethal Legacy: Bioweapons for Sale.” Washington Post, 20 April 2003.

Waterman, Shaun. "Test Reveals Wide Failures in Terror Response Abilities." Washington Times, 21 December 2003.

Weinraub, Bernard. “Army Reports Iraq is Moving Toxic Arms to its Troops.” New York Times, 28 March 2003.

Weisman, Steven R. "Private Group Prepares Visit to North Korea.” New York Times, 4 January 2004.

—. "U.S. to Send Signal to North Koreans in Naval Exercise." New York Times, 18 August 2003.

_. "Weighing 'Deterrence' vs. 'Aggression." New York Times, 18 October 2002.

Williams, Daniel. “Quick Change Suits Libyan Leader.” Washington Post, 6 March 2004.

Willman, David and Alan C. Miller. "Nuclear Threat is Real, Experts Warn." Los Angeles Times, 11 November 2001.

Woodward, Bob. “A Course of 'Confident Action." Washington Post, 19 November 2002.

Woodward, Bob, Robert G. Kaiser, and David B. Ottaway. "U.S. Fears Bin Laden Made 
Nuclear Strides.” Washington Post, 4 December 2001.

Woolsey, R. James and Thomas G. McInerney. "The Next Korean War." Wall Street Journal, 4 August 2003.

Wright, Robin. “U.S. Makes Overture to Iran.” Washington Post, 2 January 2004.

—. "Ship Incident May Have Swayed Libya." Washington Post, 1 January 2004.

\section{Government Documents}

Counterproliferation Program Review Committee. Report on Activities and Programs for Countering Proliferation and NBC Terrorism, Executive Summary. May 2002.

National Defense University, Center for Counterproliferation Research. The Counterproliferation Imperative: Meeting Tomorrow's Challenges. Washington D.C.: November 2001.

Perry, William J. "Review of United States Policy Toward North Korea: Findings and Recommendations.” 12 October 1999.

U.S. Department of Defense. Chemical and Biological Defense Program, Annual Report to Congress and Performance Plan. Washington D.C.: April 2003.

—. Nuclear Posture Review. Washington D.C.: 31 December 2001.

- Proliferation: Threat and Response. Washington D.C.: January 2001.

U.S. Department of State. Patterns of Global Terrorism, 2002. Washington D.C.: April 2003.

U.S. General Accounting Office. Post-Shipment Verification Provides Limited Assurance That Dual-Use Items Are Being Properly Used, GAO-04-357. Washington D.C.: January 2004.

U.S. Government. National Strategy for Combating Terrorism. Washington D.C.: February 2003. 
- National Security Strategy to Combat Weapons of Mass Destruction.

Washington D.C.: December 2002.

—. Joint Resolution to Authorize the Use of United States Armed Forces Against Iraq. Office of the Press Secretary, 2 October 2002.

- The National Security Strategy of the United States of America. Washington D.C.: September 2002.

\section{Speeches}

Berger, Samuel, Caspar Weinberger, and Senator Joseph Biden. Hearing on Iraq before the Foreign Relations Committee, U.S. Senate. Washington D.C., 1 August 2002. Blair, Tony. Address to a Joint Session of Congress. Washington D.C., 17 July 2003. Bolton, John R. Remarks to the Conference of the Institute for Foreign Policy Analysis and the Fletcher School's International Security Studies Program. Washington D.C., 2 December 2003.

Bush, George W. Remarks on Weapons of Mass Destruction Proliferation. Fort Lesley J. McNair, National Defense University, Washington D.C., 11 February 2004.

- Remarks by the President in Address to the Nation. The White House, Washington D.C., 17 March 2003.

- Speech at the American Enterprise Institute. Washington D.C., 26 February 2003.

- State of the Union Address. Washington D.C., 28 January 2003.

—. "Taking Action to Strengthen Small Business." St. Louis, Missouri, 22 January 2003.

—. Remarks on Iraq. Cincinnati, Ohio, 7 October 2002. - Graduation Speech. West Point, New York, 1 June 2002. 
Cheney, Richard. Speech at the Veterans of Foreign Wars $103^{\text {rd }}$ National Convention. Nashville, Tennessee, 26 August 2002.

Flournoy, Michele. "Preemption in Peacetime, Crisis and War." Speech to the National Defense University Conference on Counterproliferation. Washington D.C., 17 May 2001.

Hecker, Siegfried S. Hearing on "Visit to the Yongbyon Nuclear Scientific Research Center in North Korea," before the Senate Committee on Foreign Relations, U.S. Senate. Washington D.C., 21 January 2004.

Kadish, Robert T. Speech at the Military Appreciation Banquet. Fairbanks, Alaska, 2 March 2001

Kennedy, John F. Address to the Nation on the Soviet Arms Buildup in Cuba. The White House, Washington D.C., 22 October 1962.

LaPorte, Leon. This Week With George Stephanopoulos, ABC News Transcripts. 27 July 2003.

Perry, William. Hearing on Security Implications of the Nuclear Agreement with North Korea before the Senate Armed Services Committee, U.S. Senate. Washington D.C., 26 January 1995.

Rice, Condoleezza. Wriston Lecture to the Manhattan Institute. New York, 1 October 2002.

- Remarks on Terrorism and Foreign Policy. Paul H. Nitze School of Advanced International Studies, Washington D.C., 29 April 2002.

Rumsfeld, Donald H. Speech at the Air Force Commencement Ceremony. Colorado Springs, Colorado, 29 May 2002.

- Hearing on FY 2003 Appropriations for the Defense Department before the Appropriations Committee, U.S. Senate. Washington D.C., 21 May 2002. 
- Speech on $21^{\text {st }}$ Century Transformation of the U.S. Armed Forces. National Defense University, Washington D.C., 31 January 2002.

Schwartz, Thomas A. Hearing on North Korea before the Armed Services Committee, U.S. Senate. Washington D.C., 5 March 2002.

Tenet, George J. Hearing on "The Worldwide Threat in 2003: Evolving Dangers in a Complex World," before the Select Committee on Intelligence, U.S. Senate. Washington D.C., 12 February 2003.

Wolfowitz, Paul. Remarks at the $38^{\text {th }}$ Munich Conference on Security Policy. Munich, Germany, 2 February 2002.

Younger, Stephen. Hearing on the Defense Threat Reduction Agency before the Emerging Threats and Capabilities Subcommittee, Armed Service Committee, U.S. Senate. Washington D.C., 10 April 2002.

\section{$\underline{\text { Interviews }}$}

Baker, James. Phone interview with author, 20 November 2003.

Gallucci, Robert. Phone interview with author, 22 August 2003.

Glosson, Buster. Phone interview with author, 26 August 2003.

Perry, William. Phone interview with author, 21 August 2003.

Scowcroft, Brent. Phone interview with author, 28 August 2003.

Wit, Joel. Interview with author, 18 August 2003.

\section{Internet Resources}

Capaccio, Tony. "U.S. Tactics May Have Blunted Iraqi Chemical Threat." Bloomberg.com, 8 April 2003.

_. "Iraq Probably Can't Mount Major Chemical Attack, General Says." 
Bloomberg.com, 4 March 2003.

China. State Council Information Office White Paper, "China's Non-Proliferation Policy and Measures.” December 2003. Available at http://news.xinhuanet.com/english/2003-12/03/content_1212032.htm.

European Union. Basic Principles for an EU Strategy against Proliferation of Weapons of Mass Destruction. June 2003. Available at http://ue.eu.int/pressdata/EN/reports/76328.pdf.

http://www.danorr.com/webster/webster_ashburton_treaty.html. http://www.fas.org/nuke/guide/iraq/missile/al_hussein.htm. http://www.yale.edu/lawweb/avalon/diplomacy/britian/br-1842d.htm. Leventhal, Paul and Steven Dolley. "The North Korean Nuclear Crisis." Nuclear Control Institute, 16 June 1994. See http://www.nci.org/n/nkib2.htm.

United Nations Charter. Available at http://www.un.org/aboutun/charter/. 